\author{
UNIVERSIDADE DE SÃO PAULO \\ INSTITUTO DE ENERGIA E AMBIENTE \\ PROGRAMA DE PÓS-GRADUAÇÃO EM ENERGIA
}

CLÁUDIA MARIA TREUMANN ROCHA

ANÁLISE DO APROVEITAMENTO ENERGÉTICO DE BIOMASSA RESIDUAL EM MUNICÍPIOS COM BAIXO ÍNDICE DE DESENVOLVIMENTO: ESTUDO DE CASO BAHIA E SÃO PAULO

SÃO PAULO

2020 
CLÁUDIA MARIA TREUMANN ROCHA

\title{
ANÁLISE DO APROVEITAMENTO ENERGÉTICO DE BIOMASSA RESIDUAL EM MUNICÍPIOS COM BAIXO ÍNDICE DE DESENVOLVIMENTO: ESTUDO DE \\ CASO BAHIA E SÃO PAULO
}

\begin{abstract}
Tese apresentada ao Programa de PósGraduação em Energia do Instituto de Energia e Ambiente da Universidade de São Paulo para a obtenção do título de Doutor (a) em Ciências.

Orientador (a): $\operatorname{Prof}^{\mathrm{a}}$. Dr ${ }^{\mathrm{a}}$ Suani Teixeira Coelho
\end{abstract}

Versão Corrigida

SÃO PAULO 
AUTORIZO A REPRODUÇÃO E DIVULGAÇÃO TOTAL OU PARCIAL DESTE

TRABALHO, POR QUALQUER MEIO CONVENCIONAL OU ELETRÔNICO, PARA FINS DE ESTUDO E PESQUISA, DESDE QUE CITADA A FONTE.

\author{
FICHA CATALOGRÁFICA
}

Rocha, Cláudia Maria Treumann.

Análise do aproveitamento energético de biomassa residual em municípios com baixo índice de desenvolvimento: estudo de caso Bahia e São Paulo. / Cláudia Maria Treumann Rocha; orientadora: Suani Teixeira Coelho. -- São Paulo, 2020.

176 f.: il., $30 \mathrm{~cm}$.

Tese (Doutorado em Ciências) - Programa de Pós-

Graduação em Energia - Instituto de Energia e Ambiente da Universidade de São Paulo.

1. Biomassa. 2. Desenvolvimento sustentável. 3. Fontes renováveis de energia. I. Título 
Nome: ROCHA, Cláudia Maria Treumann

Título: Análise do aproveitamento energético de biomassa residual em municípios com baixo índice de desenvolvimento: estudo de caso Bahia e São Paulo.

Tese apresentada ao Programa de PósGraduação em Energia do Instituto de Energia e Ambiente da Universidade de São Paulo para a obtenção do título de Doutor (a) em Ciências.

Aprovado em:

\section{Banca Examinadora}

Prof.Dr. Instituição:

Julgamento: Assinatura:

Prof.Dr. Instituição:

Julgamento: Assinatura:

Prof.Dr. Instituição:

Julgamento: Assinatura:

Prof.Dr. Instituição:

Julgamento: Assinatura:

Prof.Dr. Instituição:

Julgamento: Assinatura:

Prof.Dr. Instituição: 


\section{AGRADECIMENTOS}

Ao meu companheiro, que soube me encorajar com muita paciência e compreensão nos momentos difíceis.

Aos meus filhos, Henrique e Helena, que colaboraram para o resultado deste trabalho.

À Prof. a . Suani, minha orientadora querida, por me mostrar o caminho a seguir e sempre me incentivar amorosamente.

Aos colegas do GBio, especialmente Dra. Vanessa Pecora Garcilasso, pela colaboração ao longo desses anos de estudo e trabalho no IEE.

Aos colegas do Programa de Pós Gradação em Energia que cursaram as disciplinas comigo e colaboraram para meu êxito.

Aos professores das disciplinas que cursei, por me auxiliarem na construção do saber.

Ao pessoal da Drogaria Janeiro, em Ribeirão Branco e do Restaurante Boteco do Conrado em Itapicuru, pelo apoio logístico, auxílio com as entrevistas e na percepção da cidade sob a ótica local.

Ao Eng. David Silva de Oliveira, da Coelba, pelas informações prestadas sobre o fornecimento de energia em Itapicuru.

Ao Eng. Felipe Barbosa, da Carbogás, pelas informações e auxílio no dimensionamento da unidade de gaseificação.

À CAPES - Coordenação de Aperfeiçoamento de Pessoal de Nível Superior, pelo auxílio financeiro através da concessão da bolsa de estudos. 
"Precisamos nos preocupar com um mundo que não chegaremos a ver."

(RUSSELL, 1959) 


\section{RESUMO}

ROCHA, C. M. T. Análise do aproveitamento energético de biomassa residual em municípios com baixo índice de desenvolvimento: estudo de caso Bahia e São Paulo. 2020. 177 f. Tese (Doutorado em Ciências) - Programa de Pós-Graduação em Energia. Instituto de Energia e Ambiente da Universidade de São Paulo, São Paulo, 2020.

A história do homem, contada sob o ponto de vista da apropriação da energia, demonstra que o progresso das civilizações colaborou para a instalação da desigualdade. Em 2016, eram 1,1 bilhão de pessoas no mundo sem acesso à energia, embora esta seja ingrediente essencial para unir desenvolvimento humano, sustentabilidade ambiental e crescimento econômico. O IDH (Índice de Desenvolvimento Humano), proposto pela ONU para avaliar a qualidade de vida proporcionada pelas riquezas aos cidadãos, é mensurado através de indicadores em três dimensões: saúde, renda e educação. Através dele percebe-se a desigualdade entre os países e, dentro deles, avaliada pelo IDH municipal. A dependência de fontes fósseis de energia intensifica o desafio de conter o agravamento das mudanças climáticas, associada à apropriação de recursos naturais e geração de resíduos. O Brasil, mesmo com alto IDH, tem cidades em situação precária, consideradas com baixo IDH. Nesse contexto, o seguinte trabalho analisa potencial, limitações e benefícios do aproveitamento energético da biomassa residual em dois municípios com baixo IDH (Ribeirão Branco - SP e Itapicuru - BA). Esta pesquisa teve como inspiração o projeto BREA - Biomass Residues as Energy Source to Improve Energy Acess and Local Economic Activity in Low HDI Regions of Brazil and Colombia e consistiu no levantamento de dados socioeconômicos, visitas nos municípios do estudo e estimativa do potencial de geração de energia de acordo com a melhor alternativa de tecnologia em pequena escala. Os dois municípios têm abaixo de 40 mil habitantes, com maioria da população residente na área rural, vocação para o agronegócio e IDHM 0,486 (Itapicuru) e 0,639 (Ribeirão Branco). Apesar das dificuldades nas três dimensões avaliadas pelos índices, o levantamento quantificado da disponibilidade de resíduos urbanos, industriais e agropastoris, indicou a possibilidade do aproveitamento energético através da digestão anaeróbica para esgotos, dejetos de animais e de águas residuais da atividade produtiva, com potencial de 231 $\mathrm{kW}$ e $115 \mathrm{~kW}$ para Itapicuru e Ribeirão Branco, respectivamente. Resíduos agrícolas, da silvicultura e do beneficiamento industrial de produtos do campo, bem como o RSU de ambos os municípios, podem ter seu aproveitamento através da gaseificação, auxiliando a adequação dos municípios à PNRS, com potenciais calculados de 6MW - Itapicuru e 5MW - Ribeirão Branco. A geração da energia a partir da biomassa residual produzida em ambos municípios, através da gaseificação para resíduos sólidos, em paralelo à digestão anaeróbica para dejetos de animais, esgoto e resíduos agroindustriais, de forma combinada, podem representar significativo acréscimo na energia disponível para os municípios, tendo como grande benefício a questão ambiental pela sinergia com o saneamento básico. Como o acesso à energia é indispensável para possibilitar educação, saúde e renda aos cidadãos, o aproveitamento energético da biomassa residual pode fomentar o desenvolvimento sustentável, favorecendo a segurança energética, questões ambientais e socioeconômicas. Barreiras financeiras, políticas e desinformação dificultam esse processo. Para combatê-las, medidas de incentivo, informação e divulgação são necessárias, bem como a necessidade da modernização do marco regulatório e abordagem integrada na proposta de políticas públicas voltadas às questões energéticas, ambientais e ao saneamento básico.

Palavras-chave: Energia renovável; Biomassa residual; Desenvolvimento sustentável 


\begin{abstract}
ROCHA, C. M. T. Analysis of residual biomass energy use in low development municipalities: case study Bahia and São Paulo. 2020. 177 f. Doctorate Thesis. - Graduate Program on Energy. Institute of Energy and Environment. University of São Paulo, São Paulo, 2020.
\end{abstract}

The history of humanity, told from the point of view of the appropriation of energy, demonstrates that the progress of civilizations contributed to the installation of inequality. In 2016, there were 1.1 billion people in the world without energy access, although this is an essential ingredient for uniting human development, environmental sustainability and economic growth. The HDI (Human Development Index), proposed by the United Nations Organization to assess the quality of life provided by wealth to citizens, is measured through indicators in three dimensions: health, income and education. Through it one can notice the inequality between the countries and, within them, evaluated by the municipal HDI (MHDI). The dependence on fossil energy sources intensifies the challenge of containing the aggravation of climate change, associated with the appropriation of natural resources and waste generation. Brazil, even with high HDI, has cities in precarious situation, considered with low HDI. In this context, the following work analyzes the potential, limitations and benefits of energy use of residual biomass in two municipalities with low HDI (Ribeirão Branco - SP and Itapicuru BA). This research was inspired by the project BREA - Biomass Residues as Energy Source to Improve Energy Access and Local Economic Activity in Low HDI Regions of Brazil and Colombia and consisted of surveying socioeconomic data, visits in the study municipalities and estimation of the potential for generating energy according to the best small-scale technology alternative. Both municipalities have below 40 thousand inhabitants, with the majority of the population residing in the rural area, agribusiness vocation and MHDI 0.486 (Itapicuru) and 0.639 (Ribeirão Branco). Despite the difficulties in the three dimensions assessed by the indices, the quantified survey of the availability of urban, industrial and agropastoral waste indicated the possibility of energy utilization through anaerobic digestion for sewage, animal waste and wastewater from the productive activity, with potential for $231 \mathrm{~kW}$ and $115 \mathrm{~kW}$ for Itapicuru and Ribeirão Branco, respectively. Agricultural residues, forestry and industrial processing of rural products, as well as municipal solid waste from both municipalities, can be used through gasification, helping the municipalities to adapt to national solid waste policy, with potentials estimated at 6MW - Itapicuru and 5MW - Ribeirão Branco. The generation of energy from waste biomass produced in both municipalities, through gasification for solid waste, in parallel with anaerobic digestion for animal waste, sewage and agro-industrial waste, combined, may represent a significant increase in energy available to municipalities, having as great benefit the environmental issue for the synergy with the basic sanitation. As access to energy is indispensable for citizens education, health and income, the use of residual biomass energy can foster sustainable development, favoring energy security, environmental and socioeconomic issues. Financial, political, and misinformation barriers make this process difficult. To combat them, incentive measures, information and dissemination are necessary, as well as the need for modernization of the regulatory framework and integrated approach in the proposal of public policies focused on energy, environmental issues and basic sanitation.

Keywords: Renewable Energy; Residual biomass; Sustainable development 


\section{LISTA DE FIGURAS}

Figura 2.1 - Estágios de desenvolvimento e consumo de energia...........................................26

Figura 2.2 - Usos da energia primária ao longo do tempo, no mundo.....................................29

Figura 2.3 - Índice de Desenvolvimento Humano Global......................................................33

Figura 2.4: Evolução do Índice de Desenvolvimento Humano Brasil......................................35

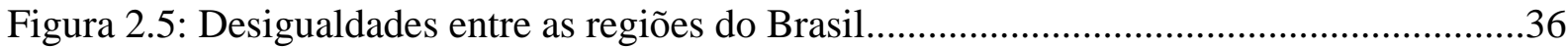

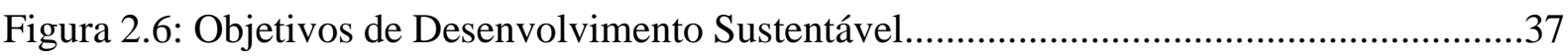

Figura 2.7: Taxa de alfabetização no mundo $(\%)$...................................................................40

Figura 2.8: $\mathrm{N}^{\mathrm{o}}$ de alunos por professor em escola primária conforme IDH............................42

Figura 2.9: IDEB no Brasil - anos iniciais da rede municipal................................................43

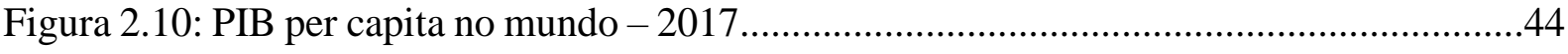

Figura 2.11: Mortalidade Infantil em 1000 nascidos vivos - 2015 .........................................46

Figura 2.12: Expectativa de vida no Brasil por Estados - 2017 .........................................48

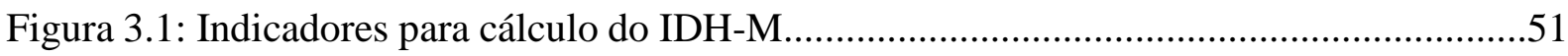

Figura 3.2: Metodologia atual cálculo do IDH-M..........................................................52

Figura 3.3: Faixas de Desenvolvimento Humano Municipal................................................52

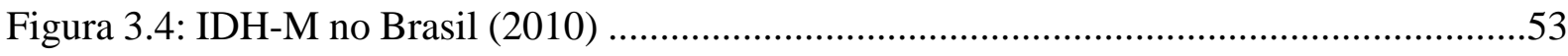

Figura 3.5: Energia consumida para cocção em residências por tipo de combustível entre 2000

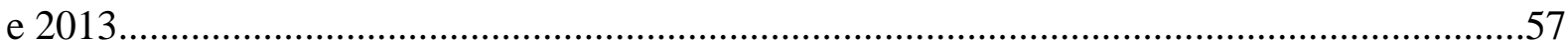

Figura 3.6: Energia primária total no mundo por fonte (2017) em percentuais.......................59

Figura 3.7: Ciclo a vapor - cogeração...........................................................................62

Figura 3.8: Serraria, Caldeira (SERMATEC) e Turbina / gerador (TGM).............................63

Figura 3.9: Fluxograma simplificado da produção e consumos finais de biometano...............65

Figura 3.10: Biodigestor e Micro central termoelétrica a biogás. Projeto Ajuricaba.................65

Figura 3.11: Posto de Abastecimento de Biometano. ETE Franca.............................................66

Figura 3.12: Rotas de gaseificação baseada no agente gaseificante........................................67

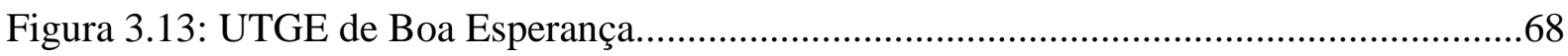

Figura 4.1: Localização do município de Itapicuru (BA) ......................................................70

Figura 4.2: Distribuição populacional por local de moradia e gênero em Itapicuru. Censo

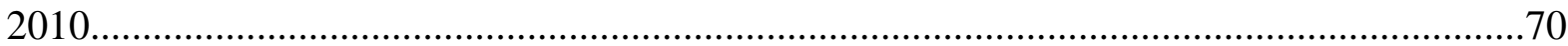

Figura 4.3: Distribuição da população residente por faixa etária. Censo 2010 ........................71 
Figura 4.4: Itapicuru. Acesso à cidade e Prefeitura municipal à direita.

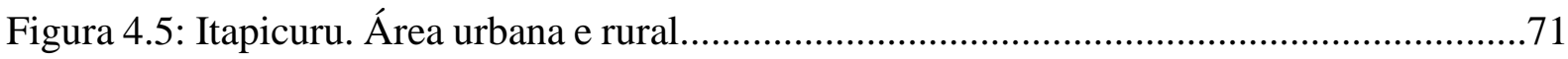

Figura 4.6: Localização do município de Ribeirão Branco (BA) .............................................72

Figura 4.7: Distribuição populacional por local de moradia e gênero em Ribeirão Branco.

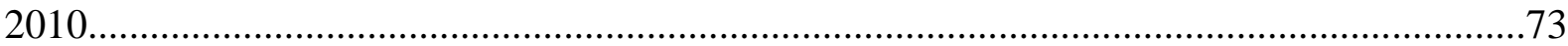

Figura 4.8: Distribuição da população residente por faixa etária. Censo 2010........................73

Figura 4.9: Ribeirão Branco. Acesso à cidade e Prefeitura municipal à direita........................73

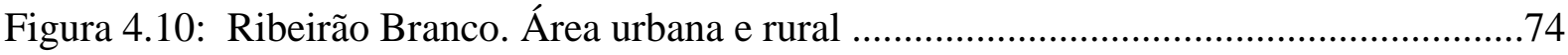

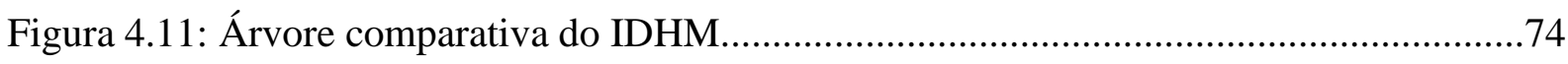

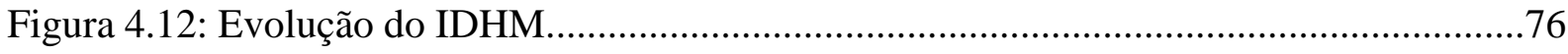

Figura 4.13: Comparativo de IDHM (2010) por dimensão...................................................76

Fig. 4.14: Percentual de habitantes com 25 anos ou mais conforme escolaridade nos municípios

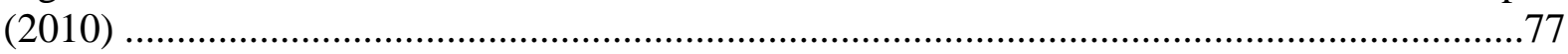

Figura 4.15: Instituições de ensino. Itapicuru (esq.) e Ribeirão Branco (dir.) .........................78

Figura 4.16: Unidades de saúde. Itapicuru (esq.) e Ribeirão Branco (dir.) ..............................79

Figura 4.17: Percentual de participação no PIB municipal por atividade (2016) .....................81

Figura 4.18: Agências bancárias. Itapicuru (esq.) e Ribeirão Branco (dir.) .............................82

Figura 4.19: Condição de atividade da população nos municípios, em percentual de habitantes

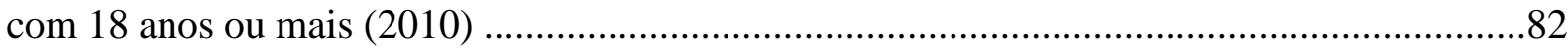

Figura 4.20: Distribuição dos habitantes ocupados com 18 anos ou mais, por setor (2010) ...84

Figura 4.21: Distribuição percentual dos habitantes ocupados com 10 anos ou mais por tipo de

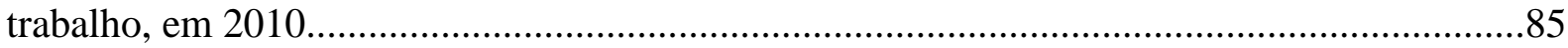

Figura 4.22: Escritório local e caixa d'água EMBASA - Itapicuru.........................................88

Figura 4.23: Caixa d'água e Estação de Tratamento de Esgoto SABESP - Ribeirão Branco....88

Figura 4.24: Percentual da disposição do lixo dos domicílios em ambos municípios (2010) ...89

Figura 4.25: Percentual da fonte de abastecimento de água dos domicílios em ambos os

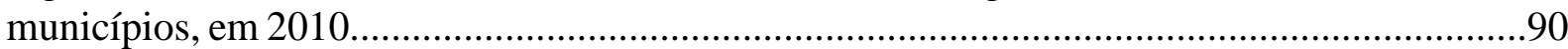

Figura 4.26: Percentual de domicílios particulares permanentes com existência de alguns bens duráveis em ambos os municípios, em 2010 ..........................................................................

Figura 4.27: Subestação de Energia Elétrica Olindina - CHESF.............................................92

Figura 4.28: Subestação de Energia Elétrica Ribeirão Branco - ELEKTRO............................92

Figura 4.29: Consumo (MWh) por classe e por ano entre 2010 - 2016 em Itapicuru..............93

Figura 4.30: Consumo (MWh) por classe e por ano entre 2010 - 2016 em Ribeirão Branco......94

Figura 4.31: Itapicuru: vista de ERB (esq.) e Estádio Municipal de Esportes (dir.) .................95 
Figura 4.32: Ribeirão Branco: vista de ERB (esq.) e biblioteca Municipal (dir.) .96

Figura 5.1: Possibilidades de aproveitamento energético para biomassa residual..................114

Figura 6.1: Interações de um lixão e o meio ambiente. 129

Figura 6.2: Saneamento e Desenvolvimento Humano. Dados de 2014 .131

Figura 6.3: Apresentação esquemática do aproveitamento energético de biomassa residual e seus principais aspectos. 142

Figura. 7.1: Evolução anual do PIB em \% 144

Figura 7.2: Disposição final (\%) de RSU no Brasil e nas regiões dos municípios estudados.147 


\section{LISTA DE TABELAS}

Tabela 2.1 - Objetivos de Desenvolvimento do Milênio............................................................37

Tabela 2.2: Média de tempo de escolaridade (anos) em alguns países (2018) ..........................41

Tabela 2.3: Expectativa de vida (anos) em alguns países (2018) ...........................................47

Tabela 3.1: População sem acesso à eletricidade em percentual.............................................55

Tabela 3.2: População sem acesso à cocção limpa em percentual...........................................55

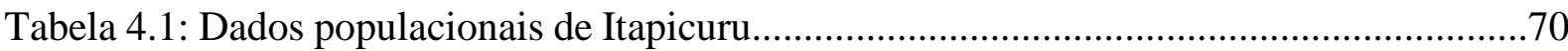

Tabela 4.2: Dados populacionais de Ribeirão Branco............................................................72

Tabela 4.3: IDHM dos municípios desmembrado em dimensões..........................................75

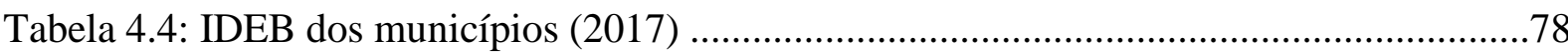

Tabela 4.5: Comparativo de dados (2010) sobre longevidade nos municípios estudados........79

Tabela 4.6: Distribuição das empresas nos municípios por setor (CNAE)

Tabela 4.7: Comparativo de renda (2010) da população ocupada com 18 anos ou mais nos municípios estudados

Tabela 4.8: Vulnerabilidade social comparativa entre os municípios (2010)

Tabela 4.9: Comparativo de indicadores de habitação (2010) nos municípios estudados. 88

Tabela 4.10: Comparativo de destinação de resíduos sólidos urbanos por regiões (2018) dos municípios estudados

Tabela 4.11: Tarifas convencional de energia elétrica, sem tributos, nos municípios estudados

Tabela 4.12: Número de consumidores em 2016 por classe nas cidades estudadas

Tabela 4.13: Aspectos de cultura e lazer nos municípios estudados. Dados de 2014

Tabela 5.1: Produção anual agrícola municipal de Itapicuru e Ribeirão Branco - culturas permanentes. Dados de 2017.

Tabela 5.2: Produção anual agrícola municipal de Itapicuru e Ribeirão Branco - culturas temporárias. Dados de 2017

Tabela 5.3: Produção de Silvicultura em Itapicuru e Ribeirão Branco. Dados de 2017. 100

Tabela 5.4: Produção de resíduos do processamento do coco da baia 102

Tabela 5.5: Produção de resíduos do processamento da mandioca. 105

Tabela 5.6: Produção calculada de resíduos da produção animal municipal de Itapicuru e Ribeirão Branco conforme dados de 2017 
Tabela 5.7: Produção calculada de resíduos da Silvicultura em Ribeirão Branco conforme dados de 2017

Tabela 5.8: Produção pecuária municipal de Itapicuru e Ribeirão Branco. Dados de 2017...109

Tabela 5.9: Produção calculada de dejetos da produção animal municipal de Itapicuru e Ribeirão Branco conforme dados de 2017

Tabela 5.10: Geração de resíduo sólido urbano per capita de acordo com a população

Tabela 5.11: Estimativa de geração de resíduo sólido e esgoto nos municípios.

Tabela 5.12: Estimativa de capacidade instalada para geração de energia por combustão direta (MW).

Tabela 5.13: Conversão energética para dejetos de diferentes origens

Tabela 5.14: Potencial de geração de metano através da digestão anaeróbica proveniente de diferentes fontes em cada cidade estudada $\left(\mathrm{m}^{3} \mathrm{CH}_{4} / \mathrm{h}\right.$ ano)

Tabela 5.15: Potência disponível (MW) pelo biogás gerado através da digestão anaeróbica proveniente de diferentes fontes em cada cidade estudada (MW)

Tabela 5.16: Resíduos utilizados e Potência disponível (MW) gerada por gaseificação nos municípios do estudo.

Tabela 5.17: Demanda calculada de energia anual nos diferentes cenários para os municípios estudados

Tabela 6.1: Custos para implantação e construção de biodigestores modelos Indiano, Chinês e Canadense por diferentes capacidades

Tabela 7.1: Resultado fiscal de 2017 148

Tabela 7.2: Geração distribuída - UTE por fonte (nov. 2019) 


\section{LISTA DE ABREVIATURAS E SIGLAS}

ABRELPE Associação Brasileira de Empresas de Limpeza Pública e Resíduos Especiais

ANEEL Agência Nacional de Energia Elétrica

BNDES Banco Nacional de Desenvolvimento Econômico e Social

BREA Biomass Residues as Energy Source to Improve Energy Access and Local Economic Activity in Low HDI Regions of Brazil and Colombia, em português - Resíduos de biomassa como fonte de energia para melhorar acesso à energia e atividade econômica em regiões de baixo IDH do Brasil e Colômbia.

CDR Combustível Derivado de Resíduo

CHESF Companhia Hidrelétrica do São Francisco

CNAE Código nacional de Atividade Econômica

COELBA Companhia de Eletricidade do Estado da Bahia

COFINS Contribuição para o Financiamento da Seguridade Social

CONAMA Conselho Nacional do Meio Ambiente

CTPS Carteira de Trabalho e Previdência Social

DBO Demanda bioquímica de oxigênio

DCNT Doenças Crônicas não Transmissíveis

DH Direito humano

DQO Demanda química de oxigênio

DTA Doenças transmitidas por água e alimentos

EMBASA Empresa Baiana de Águas e Saneamento

EMBRAPA Empresa Brasileira de Pesquisa Agropecuária

ERB Estação Rádio Base

ETE Estação de Tratamento de Esgoto

GEE Gases de efeito estufa

GLP Gás Liquefeito de Petróleo

GN Gás natural

IBGE Instituto Brasileiro de Geografia e Estatística

ICMS Imposto sobre Circulação de Mercadorias e Serviços

IDEB Índice de Desenvolvimento da Educação Básica 
IDH Índice de Desenvolvimento Humano

IDHM Índice de Desenvolvimento Humano Municipal

INAF Indicador de Analfabetismo Funcional

IPAC Instituto do Patrimônio Artístico e Cultural da Bahia

LPT Luz Para Todos

ODM Objetivos de Desenvolvimento do Milênio

ODS Objetivos de Desenvolvimento Sustentável

OMS Organização Mundial de Saúde

ONU Organização das Nações Unidas

P\&D Pesquisa e Desenvolvimento

PCI Poder calorífico inferior

PIB Produto Interno Bruto

PIS/PASEP Programa de Integração Social e o Programa de Formação do Patrimônio do Servidor Público

PMGIRS Plano Municipal de Gestão Integrada de Resíduos Sólidos

PNAD Pesquisa Nacional por Amostra de Domicílios

PNRS Política Nacional de Resíduos Sólidos

PNUD Programa das Nações Unidas para o Desenvolvimento

POF Pesquisa do Orçamento Familiar

RSU Resíduo Sólido Urbano

SABESP Companhia de Saneamento Básico do Estado de São Paulo

SIN Sistema Interligado Nacional

SMA Secretaria do Meio Ambiente

SNIS Sistema Nacional de Informações sobre Saneamento

SUS Sistema Único de Saúde

UTE Usina termo elétrica

UTGE Usina Termoquímica de Geração de Energia

WHOQOL World Health Organization instrument to evaluate quality of life, em português - instrumento de avaliação de qualidade de vida da OMS 


\section{SUMÁRIO}

1 INTRODUÇÃO

1.1 OBJETIVOS E QUESTÃO CENTRAL...........................................................19

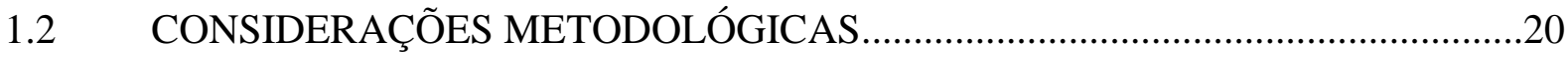

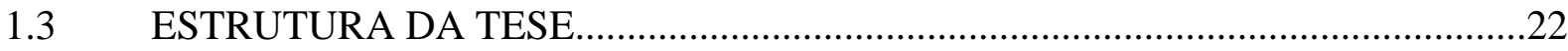

2 CONDIÇÕES DE VIDA DAS POPULAÇÕES COM MENOR IDH - A DESIGUALDADE NO MUNDO E NO BRASIL..................................................24

2.1 HISTÓRIA DO HOMEM: ENERGIA E SOCIEDADE................................................

2.2 ENERGIA E DESENVOLVIMENTO.............................................................

2.3 DESIGUALDADE NO BRASIL E NO MUNDO.................................................38

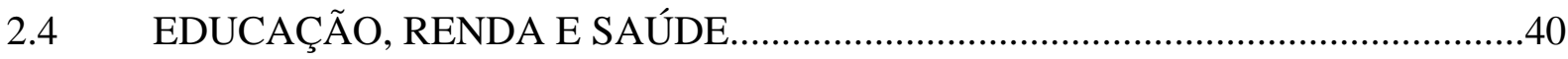

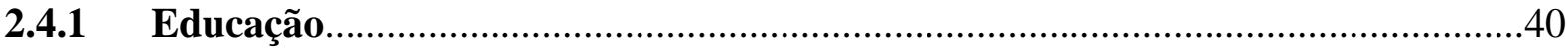

2.4.2 Renda

2.4.3 Saúde

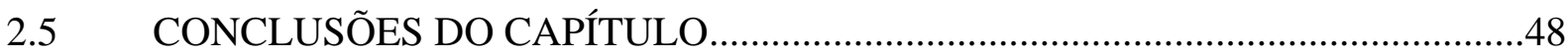

3 QUALIDADE DE VIDA, ACESSO À ENERGIA E USO DE RESÍDUOS DE BIOMASSA COMO FONTE DE ENERGIA.....................................................49

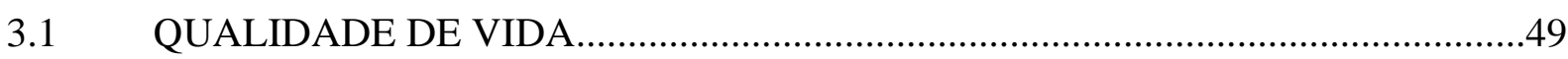

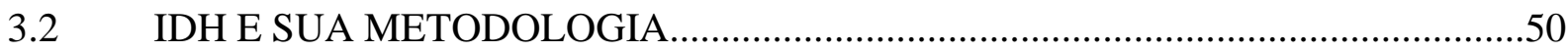

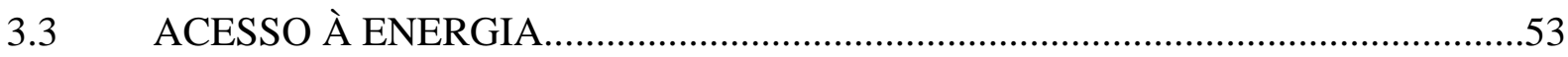

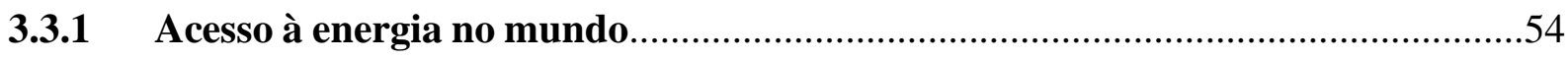

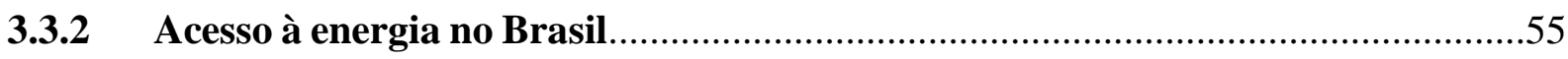

3.4 BIOMASSA RESIDUAL COMO FONTE DE ENERGIA..........................................57

3.5 POTENCIAIS DE APROVEITAMENTO ENERGÉTICO_.......................................61

3.6 TECNOLOGIAS PARA GERAÇÃO DE ENERGIA ELÉTRICA ATRAVÉS DA BIOMASSA EM SISTEMAS DE MENOR PORTE..................................................61

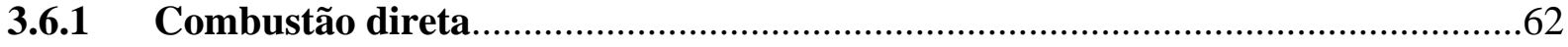

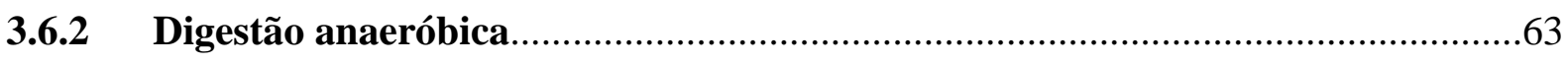

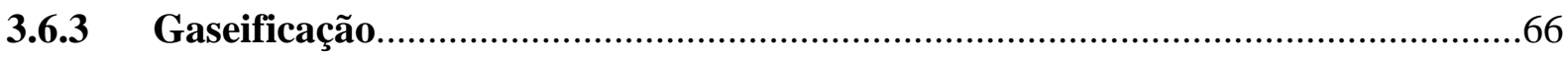

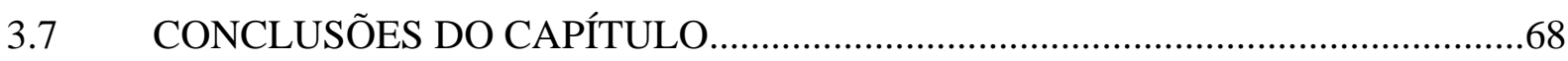

4 REALIDADES SEMELHANTES EM REGIÕES DESIGUAIS: LEVANTAMENTO DE DADOS EM ITAPICURU (BA) E RIBEIRÃO BRANCO (SP) 
4.1 CARACTERIZAÇÃO DO TERRITÓRIO - ITAPICURU (BA).............................69

4. 2 CARACTERIZAÇÃO DO TERRITÓRIO - RIBEIRÃO BRANCO (SP).................72

4. 3 ÍNDICE DE DESENVOLVIMENTO HUMANO MUNICIPAL - IDHM................74

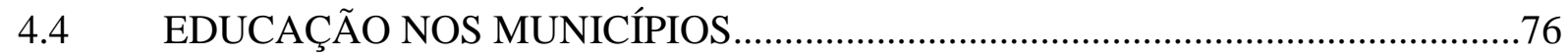

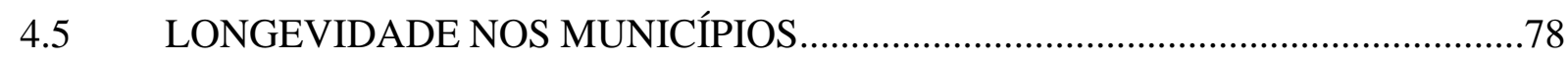

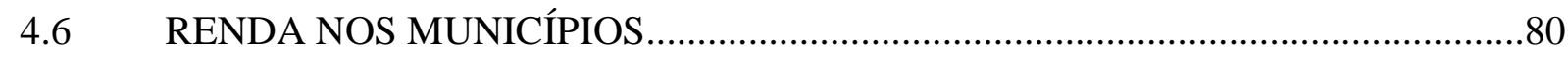

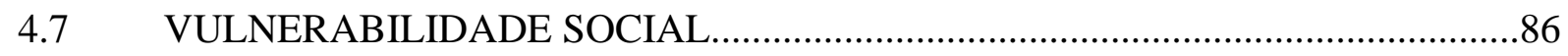

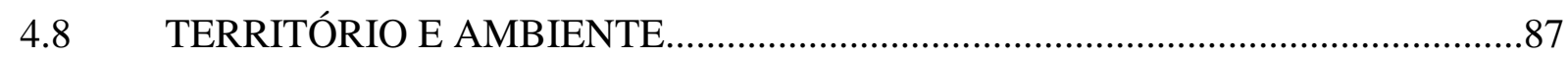

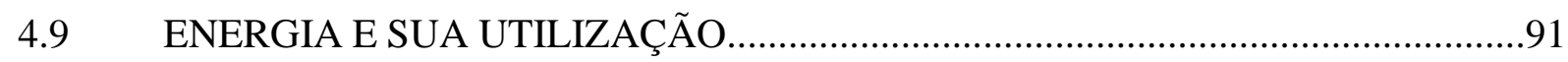

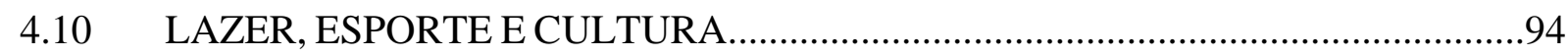

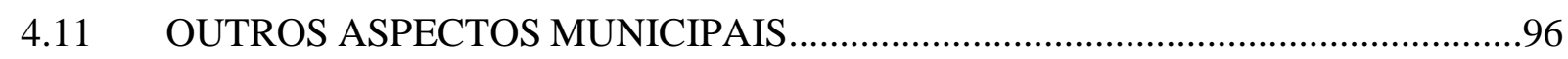

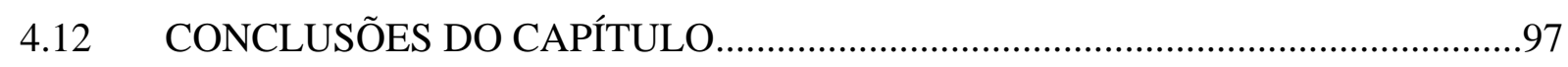

5 BIOMASSA RESIDUAL E SUAS POSSÍVEIS APLICAÇÕES PARA GERAÇÃO DE ENERGIA ............................................................................. 98

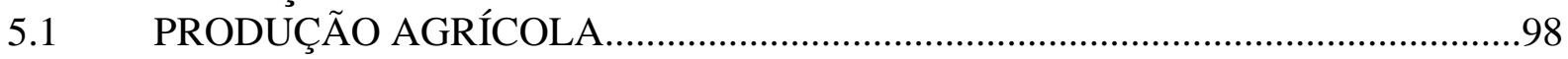

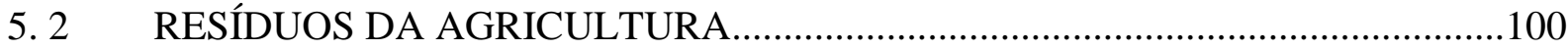

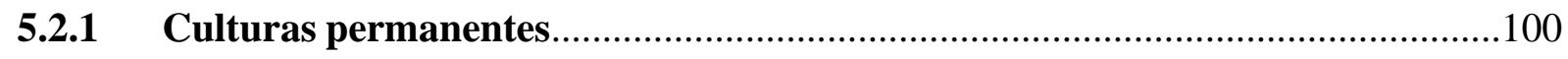

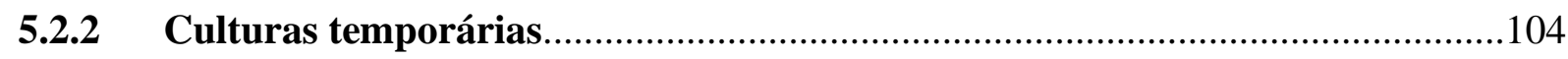

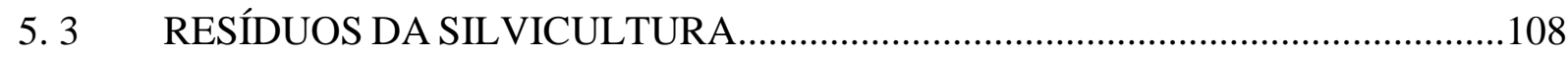

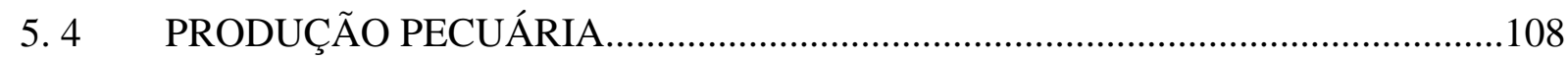

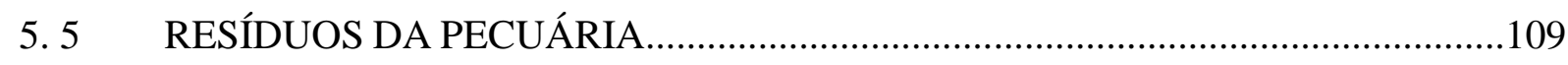

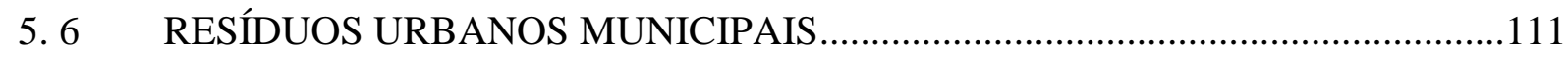

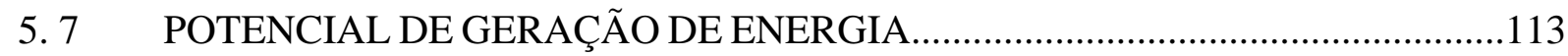

5. 7.1 Combustão direta em sistemas de pequeno porte...........................................114

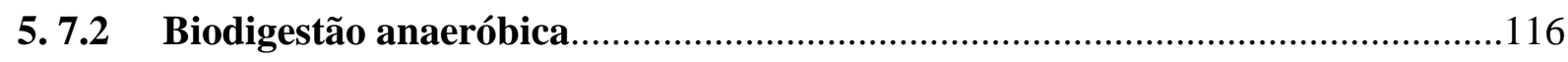

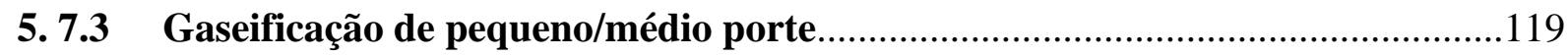

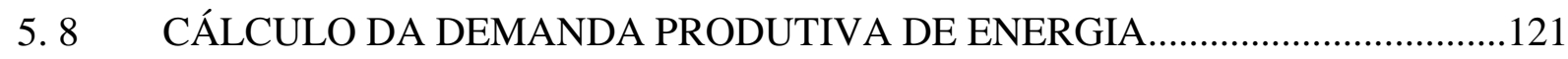

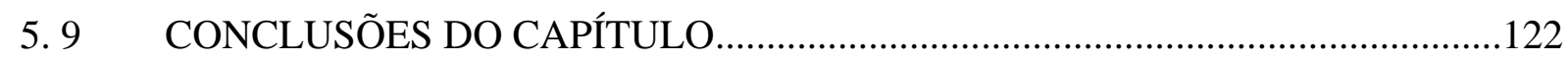

6 ASPECTOS AMBIENTAIS, SOCIAIS E ECONÔMICOS DO APROVEITAMENTO ENERGÉTICO DA BIOMASSA RESIDUAL GERADA DOS MUNICÍPIOS - SINERGIAS ENTRE APROVEITAMENTO ENERGÉTICO E SANEAMENTO BÁSICO.................................................123

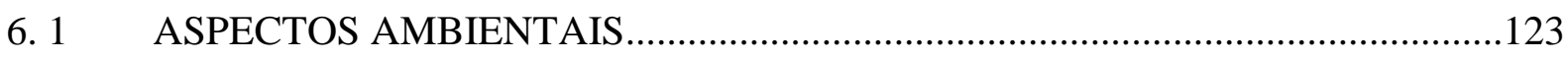

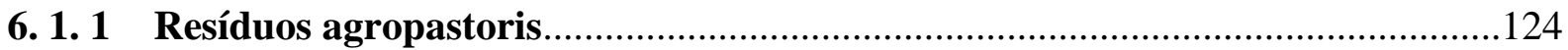




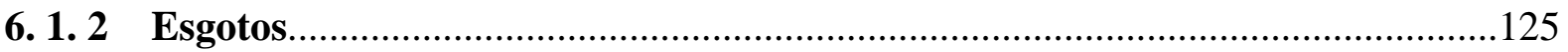

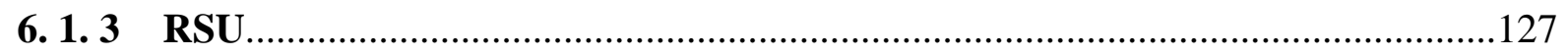

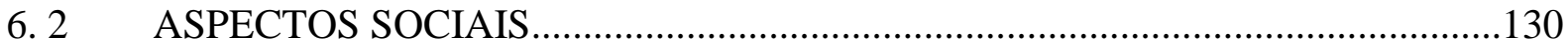

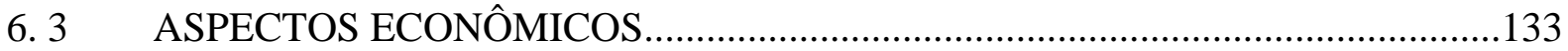

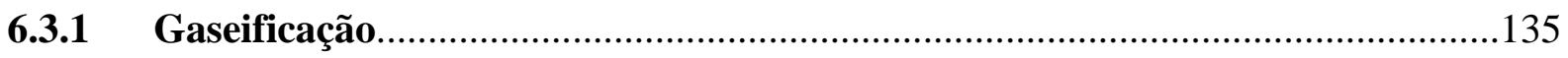

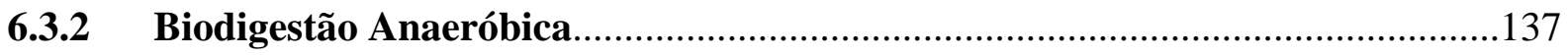

6. 4 SINERGIA ENTRE APROVEITAMENTO ENERGÉTICO E SANEAMENTO

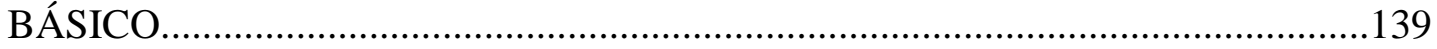

6. 5 CONCLUSÕES DO CAPÍTULO

7 ANÁLISE DAS BARREIRAS E SUGESTÃo DE MEDIDAS PARA VIABILIZAÇÃO DA UTILIZAÇÃO DA BIOMASSA RESIDUAL COMO

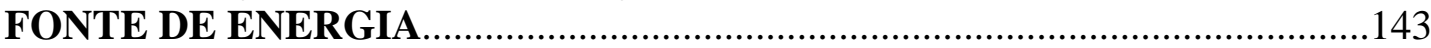

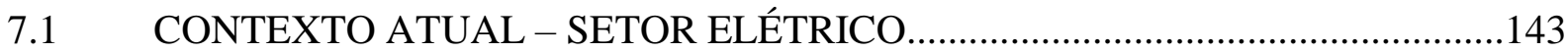

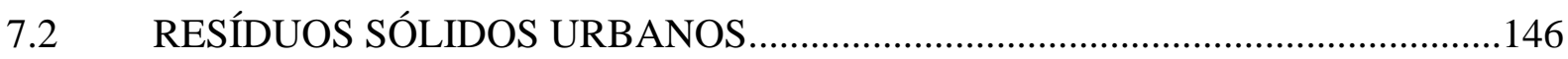

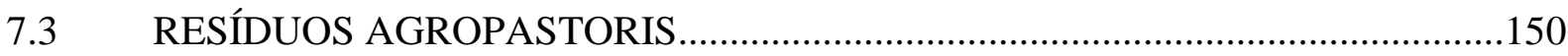

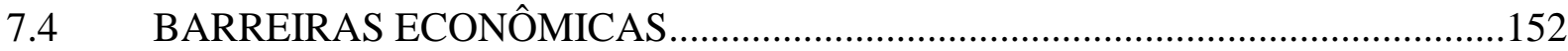

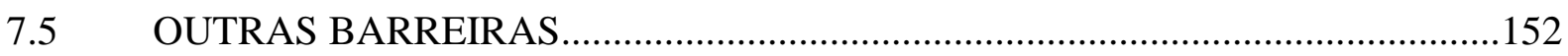

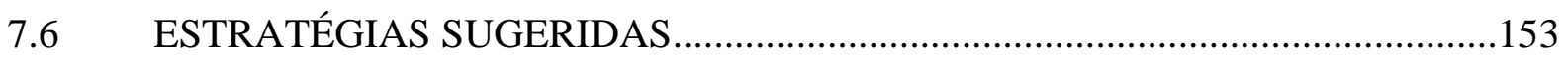

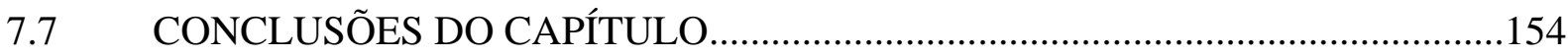

8 CONCLUSÃO

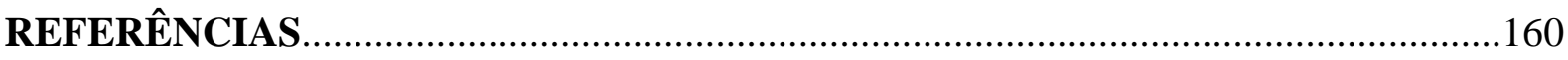




\section{INTRODUÇÃO}

Até hoje, há extrema dependência de fontes fósseis de energia, embora lentamente sua participação na matriz energética dê lugar às fontes renováveis. Mas, como o consumo energético continua em ascensão, principalmente nos países em desenvolvimento, os desafios aumentam à medida que mudanças climáticas se intensificam (COELHO e GOLDEMBERG, 2015).

A história do homem, contada sob o ponto de vista da apropriação da energia, demonstra como, ao longo do tempo, à medida que o progresso das civilizações ocorria, também se instalava a desigualdade. Quase metade da população mundial está abaixo da linha da pobreza e a fome continua a assolar, tanto aquela vista na África Subsaariana e em regiões da Ásia, como a fome oculta, onde não há qualidade de nutrientes suficientes na alimentação, presente inclusive no Brasil (WORDL BANK, 2018; FAO, 2018). Apesar da diminuição do número de pessoas sem acesso à eletricidade no mundo, em 2016 esse número estava em 1,1 bilhão de pessoas (IEA, 2017) e, Segundo Goldemberg (1998), a energia é um ingrediente essencial para o desenvolvimento sendo este o caminho que une desenvolvimento humano, sustentabilidade ambiental e crescimento econômico. No Brasil, dados de 2015 indicam a existência de 99,7\% dos domicílios com acesso à iluminação elétrica (IBGE, 2019).

O desenvolvimento de uma sociedade refere-se a um processo de evolução, crescimento, modificação para uma condição melhor. Em contraponto ao uso de indicadores econômicofinanceiros, a Organização das Nações Unidas - ONU propôs a utilização do IDH (Índice de Desenvolvimento Humano) para avaliar a qualidade de vida, o bem-estar proporcionado pelas riquezas, observando capacidades e oportunidades dos cidadãos (PNUD, 2019). Este índice é mensurado através de indicadores em três dimensões: saúde, renda e educação. Através do IDH percebe-se a desigualdade entre os países e, dentro de cada país, as desigualdades regionais avaliada pelo IDH municipal (IDHM).

O grande desafio global para equacionar crescimento e sustentabilidade (ambiental, social e econômica) foi descrito em 2015 através dos Objetivos de Desenvolvimento Sustentável (ODS), onde é imprescindível a participação ativa e global a fim de promover prosperidade e bem-estar às populações, erradicar a pobreza, proteger o meio ambiente e enfrentar da melhor forma as mudanças climáticas (ONU, 2015). 
A atividade humana se apropria de recursos naturais e gera resíduos, tanto urbanos (sólidos e líquidos) como agropastoris. Embora desde 2010 o país tem sua Política Nacional de Resíduos Sólidos (PNRS), ainda há um longo caminho a ser percorrido até sua real implementação, pois no Brasil, 1.493 municípios ainda dispôs os Resíduos Sólidos Urbanos (RSU) em valas ou lixões (ABRELPE, 2019) e apenas 83\% dos domicílios (2018) contam com coleta diária de lixo. Ainda sobre saneamento básico, 88,3\% dos domicílios (2018) tem disponibilidade de abastecimento diário de água da rede geral, sendo que apenas 59,1\% possui coleta de esgotos (IBGE, 2019).

Se a energia é fundamental para desenvolvimento sustentável, e de outro lado há a necessidade da gestão adequada de uma crescente geração de resíduos urbanos e agropastoris, o aproveitamento da biomassa residual como fonte renovável de energia, através das tecnologias já existentes, pode colaborar na disposição desses resíduos além de ser uma possível solução para municípios com baixo desenvolvimento melhorarem seus indicadores de qualidade de vida, entre eles seu IDHM.

A relevância deste tema para estudo, além de tudo já exposto acima, reside no fato de que somente através da cooperação global será possível atingir-se as 169 metas envolvidas nos 17 ODS e a sinergia entre saneamento básico e aproveitamento energético de biomassa residual pode ser indispensável para tal. No Brasil, existem inúmeros municípios com vocação para o agronegócio, mas com baixo índice de desenvolvimento humano. Assim, a busca de soluções com a interrelação entre saneamento e geração de energia a partir de resíduos equaciona grandes desafios da sociedade moderna, com foco no desenvolvimento sustentável.

A partir dessa contextualização, esse capítulo introdutório explica objetivos e questão central da tese, a estruturação da mesma bem como a metodologia empregada para tal.

\subsection{OBJETIVOS E QUESTÃO CENTRAL}

Partindo da impossibilidade de bem-estar e qualidade de vida sem acesso à energia, fundamental para atingir um patamar de desenvolvimento sustentável, e das desigualdades marcantes encontradas no Brasil, o objetivo geral deste trabalho é avaliar a possibilidade de elevação da qualidade de vida, mensurada através do IDHM, nas cidades estudadas (Ribeirão Branco - SP e Itapicuru - BA) a partir do aproveitamento de biomassa residual para geração de energia complementar. A análise é feita de forma individual e comparativa entre dois municípios detentores do menor IDHM dos respectivos estados, sendo um deles - São Paulo, o 
mais rico da Federação e o outro, Bahia, localizado numa região historicamente menos desenvolvida.

São objetivos específicos:

a) Levantar a disponibilidade de resíduos e as condições de acesso à energia elétrica nos municípios, verificando as dificuldades existentes nas diferentes regiões de cada um e identificando as melhores alternativas com relação ao tipo de resíduo e em relação à melhor tecnologia para utilização desses resíduos como fonte renovável de geração de energia;

b) Entender a percepção da sociedade local sobre dificuldades e benefícios da implementação da geração de energia através do aproveitamento de resíduos;

c) Avaliar os impactos ambiental, social e econômico em decorrência do aproveitamento energético dos resíduos de biomassa (enquanto energia renovável) existentes no município;

d) Analisar os benefícios potencialmente gerados pela produção de energia renovável nos municípios;

e) Analisar as barreiras existentes e sugerir medidas adequadas para sua implementação.

A questão central que este estudo buscou responder, pode ser assim formulada:

É possível elevar a qualidade de vida, medida através do IDHM, dos habitantes de dois municípios escolhidos (Itapicuru e Ribeirão Branco), que apresentam baixo desenvolvimento humano, através do aproveitamento da biomassa residual para geração de energia complementar?

\subsection{CONSIDERAÇÕES METODOLÓGICAS}

A proposta de se fazer um estudo de caso partiu do fato desse tipo de estudo ser bastante utilizado como estratégia de pesquisa com temas de administração pública, planejamento regional ou municipal sobre diversos temas, lidando com planejamento, análise e exposição de ideias a fim de contribuir para compreensão de fenômenos individuais, organizacionais, sociais e políticos, em casos onde o pesquisador não tem controle sobre os fatos e busca o enfoque em situações contemporâneas dentro de um contexto de realidade (YIN, 2001).

Esta pesquisa teve como inspiração o estudo realizado pelo projeto BREA - Biomass Residues as Energy Source to Improve Energy Access and Local Economic Activity in Low HDI Regions of Brazil and Colombia. Trata-se de projeto financiado pelo GNESD - Global Network 
in Energy for Sustainable Development, situado em Kopenhagen (Dinamarca), e foi executado numa parceria entre o Grupo de Pesquisa em Bioenergia - Gbio (IEE/USP), o Instituto Alberto Luiz Coimbra de Pós-Graduação e Pesquisa de Engenharia (COPPE/UFRJ), o Centro Brasileiro de Energia e Mudanças Climáticas (CBEM), o Instituto Energia e Desenvolvimento Sustentável (INEDES) e com a Universidad de La Sabana (Colômbia) (GNESD, 2015).

O objetivo principal do projeto citado foi conhecer de forma mais aprofundada as necessidades energéticas com fins produtivos em famílias de baixa renda, nas regiões de menor desenvolvimento humano tanto no Brasil como na Colômbia. Partindo do levantamento da disponibilidade de biomassa urbana e rural, buscou-se traçar possibilidades para e geração de energia a partir desses resíduos (através de combustão direta, gaseificação e digestão anaeróbica), permitindo eletrificação e melhoria das atividades produtivas locais, impactando positivamente o desenvolvimento humano desses municípios estudados (GNESD, 2015).

Assim, partindo de um município que participou do estudo do BREA, no caso Itapicuru (BA), buscou-se localizar outro município com baixo IDHM, desta vez num Estado mais rico, a fim de mostrar que as desigualdades existem de forma global, mas também entre os Estados da Federação e Municípios do mesmo Estado. Esse foi o critério de escolha de Ribeirão Branco, município com o menor IDHM do Estado de São Paulo, que é o mais rico do Brasil e onde está localizado o município de maior IDHM do país - São Caetano do Sul, considerado com muito alto índice de desenvolvimento.

A coleta de dados foi feita em duas etapas: a primeira baseada em dados secundários extraídos do projeto BREA - Biomass Residues as Energy Source to Improve Energy Access and Local Economic Activity in Low HDI Regions os Brazil and Colombia, coordenado no Brasil pela Profa. Dra Suani Coelho. Outros dados secundários provêm de sítios eletrônicos (dados geográficos, econômicos, sociodemográficos, ambientais, entre outros).

A segunda etapa consistiu em visita de campo aos municípios: Ribeirão Branco, em abril de 2018 e Itapicuru, em dezembro de 2018. Neste momento foram coletadas informações e percepções através de entrevistas não estruturadas a munícipes, observação e registro fotográfico da realidade. Visitou-se a região urbana e rural dos municípios (de acordo com as possibilidades de mobilidade e segurança), estações de tratamento de água e esgoto, subestação de energia elétrica, comércio local, prédios públicos, agências bancárias, unidades de saúde, escolas, cooperativas de coleta seletiva, entreposto de produtos agrícolas, entre outros. 
O primeiro visitado foi Ribeirão Branco, município do sul do Estado de São Paulo, distante $230 \mathrm{~km}$ da capital paulista, com acesso por rodovias federais e estaduais asfaltadas e bem conservadas. Em outro momento, visitou-se Itapicuru, município do nordeste baiano, distante $250 \mathrm{~km}$ da capital - Salvador, também com acesso por rodovias federais e estaduais, asfaltadas e razoável estado de conservação (GOOGLE MAPS, 2017).

Os dados quantitativos coletados foram analisados com auxílio de ferramentas estatísticas e serviram para desenhar um cenário e auxiliar a interpretação e explicação sobre questões que motivaram a investigação, após mergulho analítico profundo.

A análise dos dados qualitativos coletados nas entrevistas em campo foi feita através da análise de conteúdo, método que possui funções como a verificação de hipóteses e descoberta do que está por trás dos conteúdos manifestos, buscando fazer inter-relações entre o tema investigado e o expressado pelos entrevistados (MINAYO, 2001).

\subsection{ESTRUTURA DA TESE}

Para atingir os objetivos a que se propõe, esta tese foi estruturada em oito capítulos, sendo que a revisão bibliográfica está distribuída nos capítulos II e III. A disposição dos assuntos se deu da seguinte forma:

I. Introdução.

Este capítulo, como o nome sugere, traz a contextualização do problema, elenca os objetivos do estudo, a metodologia empregada e a estruturação da tese.

II. Condições de vida das populações com menor IDH - a desigualdade no mundo e no Brasil.

O segundo capítulo aborda as desigualdades do mundo e do Brasil, mensuradas através de índices e indicadores como o Índice de Desenvolvimento Humano (IDH) entre outros, além de discutir dados sobre saúde, renda e educação das populações sempre enfatizando as desigualdades.

III. Qualidade de vida, acesso à energia e uso de resíduos de biomassa como fonte de energia.

O propósito deste capítulo é apresentar revisão bibliográfica sobre qualidade de vida, através do IDH e sua metodologia de cálculo. Discute-se o acesso à energia e possibilidade de utilização da biomassa residual para geração de energia elétrica, abordando algumas tecnologias viáveis para tal (combustão direta, digestão anaeróbica e gaseificação). 
IV. Realidade semelhantes em regiões desiguais: levantamento de dados em Itapicuru (BA) e Ribeirão Branco (SP).

O capítulo quarto traz resultados e discute dados sociodemográficos dos municípios estudados, através de gráficos e tabelas comparativas.

V. Biomassa residual e suas possíveis aplicações para geração de energia.

Este capítulo, a partir de dados da produção agropecuária, número de habitantes e outros dados (estatísticos e da literatura), apresenta cálculo de resíduos e faz estimativa do potencial de geração de energia a partir da biomassa residual dos dois municípios do estudo.

VI. Aspectos ambientais, sociais e econômicos do aproveitamento energético da biomassa residual gerada dos municípios - sinergias entre aproveitamento energético e saneamento básico.

O capítulo sexto faz a análise de dados coletados, de forma individual e comparativa, mostrando impactos ambientais, sociais e econômicos do uso da energia complementar para modificação da qualidade de vida das populações estudadas, além de traçar possível sinergia entre aproveitamento energético e saneamento básico.

VII. Análise das barreiras e sugestão de medidas para viabilização da utilização da biomassa residual como fonte de energia.

O sétimo capítulo discute as principais barreiras para implantação do aproveitamento da biomassa residual como energia complementar, bem como sugere propostas de políticas públicas e outras medidas para o aproveitamento dos resíduos como fonte energética alternativa.

VIII. Conclusão.

Por fim, as conclusões do estudo do impacto da elevação do IDHM dos dois municípios estudados com a geração de energia complementar através de biomassa residual. 


\section{CONDIÇÕES DE VIDA DAS POPULAÇÕES COM MENOR IDH - A DESIGUALDADE NO MUNDO E NO BRASIL}

O conceito de desigualdade é ausência de proporção ou equilíbrio, estado de coisas ou pessoas que não são iguais entre si. A desigualdade permeia grande parte das atividades humanas, nas diferentes regiões do planeta. É possível exemplificar esse conceito, observando as desigualdades existentes em diferentes áreas: raciais, de gênero, sociais, entre outras. A desigualdade social tem um significado amplo, e acarreta diretamente a pobreza, a fome e a violência, reduzindo significativamente a qualidade de vida das populações.

Segundo o Banco Mundial, embora menos pessoas vivam numa situação de pobreza extrema (renda abaixo de US\$1,90 per capita por dia), quase metade da população mundial (3,4 bilhões de pessoas) ainda se encontra abaixo da linha da pobreza ( renda abaixo de US\$ 3,20 per capita por dia em países de renda média-baixa e US\$ 5,50 em países de renda médiaalta) (WORLD BANK, 2018).

A fome continua crescente. Apesar da tecnologia aplicada ao agronegócio mundial trazer produtividades bastante significativas, dados da Organização das Nações Unidas, em 2018, relatam que 820 milhões de pessoas no mundo estavam em situação de insegurança alimentar, sem acesso suficiente a alimentos (em quantidade e qualidade), com o terceiro ano consecutivo de aumento desse número (FAO, 2018). Essas populações desnutridas existem por inúmeros fatores como a desigualdade, má distribuição de recursos, desperdício de alimentos (aproximadamente 1/3 se perde em toda cadeia do campo à mesa) entre outros, mas é pouco provável que a causa seja falta de alimentos.

Dados de 2015 fornecidos pelo Programa das Nações Unidas para o Desenvolvimento (PNUD) citavam que quase 8 milhões de brasileiros (aproximadamente $4 \%$ da população do país) sofria privações no acesso à educação, saúde, água potável e saneamento básico, eletricidade e moradia adequada (PNUD, 2019).

A fim de aprofundar a análise sobre a desigualdade mundial e no Brasil, deve-se começar a discussão do início, nos primórdios da formação das sociedades. Neste capítulo, a história do ser humano na Terra é contada sob a ótica da apropriação de energia, desde os primeiros tempos da raça humana até os dias atuais, passando pela formação das sociedades e a instalação da desigualdade. 


\subsection{HISTÓRIA DO HOMEM: ENERGIA E SOCIEDADE}

A história do homem na Terra se confunde com a apropriação da energia feita por ele, atividade essencial por razões biológicas, econômicas, sociais, políticas, psicológicas e culturais. Ao longo do tempo, os seres humanos definiram energia de várias formas. Suas definições são operacionais, ou seja, permitem mensuração e cálculo. Mas, de uma forma bem simples, energia é a capacidade de realizar trabalho, podendo ser cinética, gravitacional, elétrica, química, térmica, radiante e nuclear (GOLDEMBERG \& LUCON, 2012).

O ser humano, para a manutenção de suas necessidades biológicas, obtém energia através da alimentação. Porém existem outras necessidades que se modificaram com os vários estágios do desenvolvimento da civilização. Atualmente consome-se energia para iluminação, condicionamento térmico, mobilidade, comunicação, produção de bens de consumo e serviços. Esse consumo varia de acordo com a localização geográfica, fatores políticos, grau de desenvolvimento e indicadores socioculturais.

Goldemberg \& Lucon (2012) trazem que, ao longo da história, o consumo energético per capita foi de $2000 \mathrm{kcal} /$ dia aproximadamente para o homem primitivo africano, há um milhão de anos, passando pelo homem caçador europeu (cem mil anos atrás), o homem agrícola primitivo (5000 a.C.), o homem agrícola avançado da Idade Média (1400 d.C.), o homem industrial inglês (1875) até o homem tecnológico do Sec. XX, conforme a figura 2.1.

A apropriação de energia pelo ser humano acarreta impactos sociais e ecológicos, desde as sociedades caçadoras-coletoras, se modificando com a revolução agrícola e posteriormente com a industrial. As fontes energéticas utilizadas ao longo da existência do homem, desde a biomassa, as fontes fósseis e a energia nuclear, foram manipuladas de acordo com as necessidades de cada época, acarretando grandes movimentos sociais. Essas transformações e suas consequências são discutidas ao longo do tempo por vários estudiosos (BURKE III, 2009).

Conforme citado por Crosby sobre Darwin, o domínio do fogo, foi o maior avanço do homem depois da linguagem, por suas inúmeras funções de iluminação, proteção, aquecimento e principalmente a cocção que proporcionou melhor condição nutricional ao ser humano, possibilitando o desenvolvimento anatômico dos indivíduos: o tamanho dos dentes diminuiu, as mandíbulas tornaram-se menos vigorosas e o tamanho do cérebro que triplicou ao longo de 4 milhões de anos. A maior condição física possibilitou maior interação social para desenvolvimento de ferramentas e expressões artísticas, bem como habilidades de comunicação e toda estruturação social advinda das novas formas de produção e trabalho (CROSBY, 2006). 


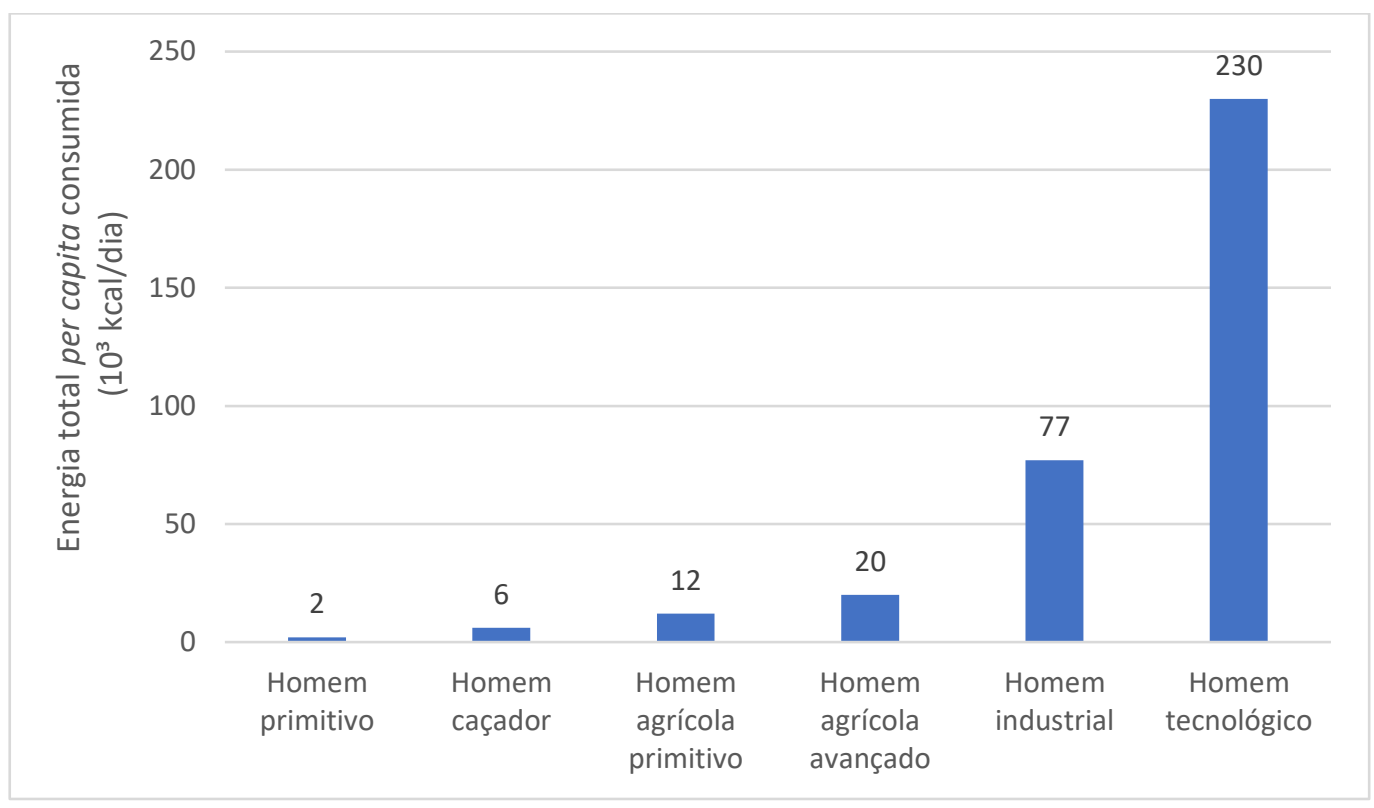

Figura 2.1: Estágios de desenvolvimento e consumo de energia.

Fonte: preparado pela autora baseado em Goldemberg \& Lucon (2012).

Segundo Diamond (2002), a percepção que seria mais fácil domesticar plantas e animais ao invés de competir pelos recursos naturais, fez o homem utilizá-los a seu favor para alimentação e utilização da força animal, fato que teve como consequências a monotonia alimentar, surgimento de doenças, modificação na estrutura corporal, surgimento de classes sociais, surgimento de exércitos e a alteração de comportamento dos indivíduos.

O sedentarismo possibilitou também o acúmulo de objetos de tecnologia mais pesada. Tais fatores levaram a uma explosão demográfica, além de evoluções tecnológicas, sociais e culturais. As grandes expansões agrícolas foram possíveis pela domesticação de plantas e animais, como mamíferos, herbívoros e onívoros. Se por um lado há maior necessidade de alimentos para suprir ao crescente número de habitantes, esse fato aumenta a pressão sobre o meio ambiente (DIAMOND, 2002).

O adensamento populacional só foi possível graças ao excedente energético. A produção de vegetais e a criação de animais sustentava a sociedade emergente. Os animais, além de servir de alimento, eram fonte de aquecimento, vestuário, meio de transporte, combustível e força de trabalho. Devido ao estilo de vida, as mudanças climáticas afetavam diretamente a existência do homem, ocasionando muitos períodos de escassez e fome. O cultivo de terras modificou a estrutura social e de produção. Houve divisão de trabalho, afetando diretamente a relação entre consumo e gasto energético. A utilização da biomassa tradicional para uso como combustível 
foi dominante. Utilizava-se madeira (seca preferencialmente), palhas e restos vegetais e, em regiões sem tantas opções vegetais, estrume seco de animais (SMILL, 2006).

A agricultura fez surgir novas tarefas, o sedentarismo e as classes sociais. Enquanto caçadores-coletores viviam em movimento, sempre buscando melhores condições de alimentação, a agricultura possibilitou a formação de agrupamentos fixos, sem que os hábitos de caça e coleta fosse abandonado, mesmo sendo esses mais dispendiosos energeticamente falando. Ferramentas de metal e pedra auxiliaram o desenvolvimento da agricultura ao longo dos tempos. Desde sempre as alterações climáticas interferem e condicionam estratégias de adaptação dos seres humanos por todo o planeta (GRUPTA, 2004).

O desenvolvimento da metalurgia se deu à medida que o homem conseguia dominar o fogo, sua contenção, alimentação de ar e combustível, que por muito tempo foi preferencialmente o carvão vegetal. Mais uma vez a apropriação e controle da energia possibilita um salto no desenvolvimento das sociedades e, com esse salto, a desigualdade se estabelece (CRADDOK, 2000).

A trajetória da utilização da madeira como combustível se deu, à medida das necessidades crescentes que emergiam da nova sociedade, modificando as paisagens com a destruição das florestas. Com o uso da lenha como combustível e material de construção, a demanda chegou a tal ponto que o Estado teve que intervir para atenuar os conflitos, mas, com isso, o homem percebeu que chegava a um impasse: sem novas fontes de energia não seria possível a manutenção do sistema. Os recursos naturais tinham chegado ao limite. Eis o gatilho para o uso dos combustíveis fósseis (SIEFERLE, 2001).

Mesmo com a força animal e a escravidão, a sociedade urgia por mais energia, sendo que tecnologias foram desenvolvidas para aproveitamento da energia eólica, hidráulica e solar. É nítida a contribuição dos romanos no desenvolvimento e disseminação de tecnologias aplicadas ao uso da energia, trazendo avanços e modificações nas sociedades (WIKANDER, 2008).

Apesar da força expansiva dos gases ser conhecida desde Héron de Alexandria (10 d.C 70 d.C) que idealizou um equipamento que utilizava o aquecimento do ar para realizar trabalho mecânico, ao final do século XVIII, Thomas Newcomen criou uma máquina de grandes dimensões, que consumia muito carvão e produzia apenas $4 \mathrm{hp}$. O vapor gerado pela água aquecida movia um êmbolo. James Watt otimizou o sistema no início do século XIX, incrementando - lhe a eficiência - a máquina a vapor, que mais tarde foi usada na indústria têxtil e nas locomotivas, iniciando a Revolução Industrial (GOLDEMBERG \& LUCON, 2012). 
A utilização de combustíveis fósseis em maior escala fomentou a revolução industrial. A energia disponibilizada pelo carvão mineral possibilitou avanços tecnológicos com impactos econômicos, sociais e ambientais. A sociedade europeia que se via limitada ao crescimento pela escassez de madeira, descobre no carvão grande potencial com seu poder calorífico. Todas as dimensões da vida humana sofreram impactos com a utilização do novo combustível (SIEFERLE, 2001).

Surge nova ordem política, social e econômica no mundo como consequências da revolução industrial, da urbanização, seus impactos na produção de alimentos, utilização de combustíveis e no meio ambiente. Todo o progresso e desenvolvimento não foram capazes de resolver os problemas do mundo, contribuindo sobremaneira para a injustiça e desigualdade social (GODFRAY et al, 2010).

Smill (2013) relata que, considerando alimentação, longevidade, condições de vida, combustíveis consumidos, formas de deslocamento e materiais utilizados, não havia modificações tão radicais até a sociedade pré-industrial do século XVIII. Fome não era frequente. A grande mortalidade infantil fazia a expectativa de vida ser próxima de 40 anos, as moradias eram sem higiene e desconfortáveis, o combustível predominante era a madeira (e o carvão feito com ela) e resíduos vegetais, a força humana e animal prevaleciam.

O sec. XIX operou grandes transformações na Inglaterra, parte da Europa, Estados Unidos e Japão. A modernização puxada pela industrialização e urbanização fez dois processos ocorrerem: enorme apropriação / extração dos materiais tradicionais para construção e incremento no consumo de metais. A urbanização demandou novas edificações, ferrovias, portos e rodovias que demandaram muito material de construção e energia de transformação. A sociedade moderna do sec. XX, fortemente dependente de energia, criou muitas combinações entre técnica, ciência e gestão, proporcionando novo cenário econômico e social, que interferiu diretamente na qualidade de vida das pessoas. A geração de resíduos vegetais passa a ser significativa e sua utilização / reciclagem torna-se importante. O uso da madeira como combustível é desigual entre os países de acordo com seu grau de desenvolvimento econômico, mas a grande fonte energética passa a ser os combustíveis fósseis (SMILL, 2013). 


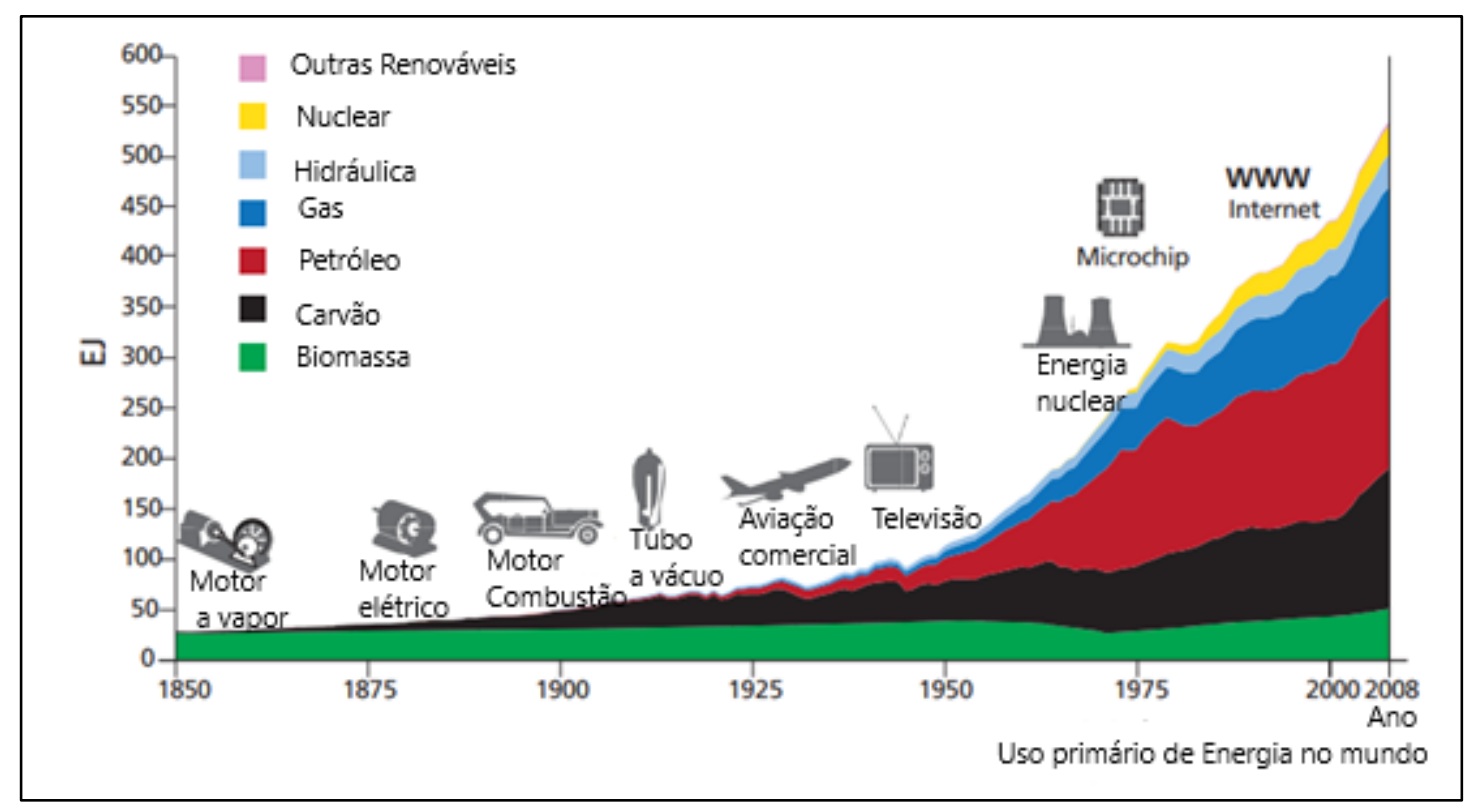

Figura 2.2: Usos da energia primária ao longo do tempo, no mundo.

Fonte: IIASA (2012)

Na figura 2.2 é possivel observar dois momentos de explosão do uso da energia: a entrada do carvão em detrimento da biomassa tadicional e outro, com a utilização de petróleo e gás (IIASA, 2012).

O consumo de energia elétrica tem se elevado nos setores comercial, residencial e industrial, de forma que a eficiência energética se torna assunto de grande importância. Para países em desenvolvimento, a eficiência energética pode ser fator para minimizar e/ou reduzir importação de combustíveis para geração de energia (HARISH \& KUMAR, 2016).

Conforme Chiri \& Giovagnori (2012), desde 2007 mais de 50\% da população mundial vive em cidades. Nas últimas 4 décadas, houve grande migração das pessoas. O processo de urbanização que ocorreu após a Revolução Industrial nos países desenvolvidos e depois, nos países em desenvolvimento, impactam fortemente o consumo de energia (principalmente os fósseis) e as emissões de $\mathrm{CO}_{2}$. A estreita relação entre energia e sociedade é percebida desde as primeiras aglomerações de pessoas, quando a energia provinha basicamente da força muscular humana ou animal. $\mathrm{O}$ uso do carvão como fonte energética em substituição à madeira fomentou o desenvolvimento de sistemas de transporte e infraestrutura, disponibilizando a “energia" no local de consumo. 
A eletricidade e o petróleo (juntamente com as inovações tecnológicas) permitiram crescimento e desenvolvimento das populações, ligados à disponibilidade e uso da energia (renováveis ou não). O metabolismo voraz da sociedade consome e desperdiça muita energia para seu funcionamento. Grande quantidade de energia é consumida para o crescimento das cidades e sua organização interna, liberando de outro lado, resíduos e poluentes, como "ilhas de entropia decrescente". Os municípios podem ser grandes problemas ou se tornarem estratégicas para novas formas de utilização de energia e desenvolvimento de um pensamento sustentável (CHIRI \& GIOVAGNORI, 2012).

A intensidade de uso da energia presente nas sociedades atuais merece atenção, sendo recomendável a introdução de energias renováveis e limpas, que certamente farão novas transformações no contexto socioeconômico das populações, onde a sustentabilidade será traduzida pela autossuficiência de cada comunidade com seus recursos disponíveis. No século XXI, com os conflitos nas áreas de exploração de combustíveis fósseis, problemas climáticos de origem antropogênica e depleção das reservas fósseis, surgem motivos suficientes para a busca de fontes renováveis de energia (ADIL \& KO, 2016).

Ainda segundo os mesmos autores, a tendência ao sistema descentralizado sugere produção, distribuição e consumo no local, servindo-se de energias renováveis, oferecendo situação com baixo investimento, emissões reduzidas de GEE, independência e segurança energética. O sistema descentralizado contribui com o meio ambiente, a economia e com aspectos sociais ligados à sustentabilidade. A tecnologia emergente vincula uso da terra e geração de energia limpa, como a biomassa. $\mathrm{O}$ avanço das tecnologias que envolvem energias renováveis dá ao consumidor a possibilidade de gerar sua própria energia, tornando-se agente ativo do processo. As comunidades em situação de vulnerabilidade devem ser consideradas de forma prioritária (ADIL \& KO, 2016).

A energia disponível nas cidades é produto de relações sociais, afetando meio ambiente, economia e qualidade de vida. O acesso não é uniforme, sendo distribuído de acordo com a riqueza das regiões. As desigualdades são reforçadas por esses fatores. As novas realidades forçam a busca por soluções para tornar os municípios, grandes ou pequenos, locais de condições de vida melhores, seja nas habitações, na mobilidade urbana, em questões envolvidas na renda, longevidade ou educação, todas essas dependentes do consumo de energia. 


\subsection{ENERGIA E DESENVOLVIMENTO}

Ao longo da história da humanidade, o desenvolvimento foi acontecendo de forma desigual. Na atualidade, temos países com excelente qualidade de vida e, por ouro lado, locais onde a vida é quase de subsistência. $\mathrm{O}$ conceito de desenvolvimento pode ser atrelado às dimensões econômicas, sociais ou ambientais.

Embora desenvolvimento econômico e consumo de energia estejam ligados, nem sempre a relação é direta. Existe um custo energético para as necessidades básicas das populações que variam com condições climáticas e socioculturais, mas a sociedade moderna, considerada uma sociedade dual, faz diferenciação entre ricos e pobres na utilização da energia. Enquanto as elites se voltam para um consumo nos padrões de países desenvolvidos, os pobres buscam energia para suas necessidades básicas como acesso a emprego e renda, alimentação, serviços de saúde, moradia e infraestrutura decente (GOLDEMBERG \& LUCON, 2012).

Tendo como missão contribuir para a erradicação da pobreza, redução das desigualdades e da exclusão social, em 1966, a Assembleia Geral das Nações Unidas, estabeleceu o Programa das Nações Unidas para o Desenvolvimento (PNUD), com sede nos Estados Unidos e atuando em aproximadamente 170 países e territórios (PNUD, 2017).

A fim de desacoplar qualidade de vida do crescimento puramente econômico, o PNUD, para oferecer um contraponto ao Produto Interno Bruto (PIB) per capita, um indicador econômico, passa a utilizar o Índice de Desenvolvimento Humano (IDH), criado por Mahbub ul Haq e Amartya Sem. Trata-se de uma medida geral e sintética que considera o progresso do desenvolvimento humano a longo prazo, em três dimensões básicas: renda, educação e saúde. Com isso, há uma mudança de perspectiva pois os números consideram não só a renda, mas como o ser humano vive e o que faz com ela (PNUD, 2017).

Embora a tendência global aponte para o avanço do desenvolvimento humano, ainda há muita desigualdade no mundo. Assim, ainda que o Relatório do Desenvolvimento Humano 2015 indique que o Índice de Desenvolvimento Humano (IDH) dos países não tenha apresentado resultados inferiores aos verificados em 2000, um avanço quanto a esse cenário, deve-se destacar que pleno século XXI, populações ainda vivem em condições sub-humanas.

O Relatório de Desenvolvimento Mundial de 2016, divulgou uma classificação de IDH Global. Nele, o primeiro colocado é a Noruega, com IDH 0,949, considerado muito alto 
desenvolvimento humano. Os Estados Unidos, grande potência econômica, se classifica em $10^{\circ}$ lugar, com IDH 0,920, mostrando que nem sempre poderio econômico é traduzido em bemestar da sociedade. O Brasil está em $79^{\circ}$ lugar, com IDH 0,754, considerado alto desenvolvimento humano, atrás de Argentina, Chile, Uruguai e México. Mais à frente, comenta-se que, embora o Brasil esteja categorizado no grupo de alto desenvolvimento humano, existem enormes desigualdades entre os Estados e Municípios que compõe o país. (UNDP, 2018).

Na parte inferior da classificação, pode-se observar os países com os mais baixos índices de desenvolvimento humano. A pior colocação fica para República Centro-Africana, com IDH 0,352, considerado baixo desenvolvimento humano. Nota-se que grande parte dos países considerados com baixos índices de desenvolvimento humano encontram-se no continente africano, conforme a figura 2.3, que mostra a distribuição do IDH no mundo. Esse dado mostra como a desigualdade das condições de vida se dão no planeta (UNDP, 2018).

O IDH considera o desenvolvimento em três dimensões - educação, saúde e rendimento - mas a realidade aponta que o crescimento econômico por si só não se traduz em melhoria da qualidade de vida das populações, afinal, cerca de 1,5 bilhões de pessoas vivem em situação de pobreza multidimensional no mundo (PNUD, 2014). A figura 2.3 mostra a distribuição do IDH no mundo.

O conceito de desenvolvimento sustentável surgiu numa perspectiva ambiental, durante a primeira Conferência da ONU sobre Meio Ambiente, na Suécia na década de 1970, como aquele capaz de suprir as necessidades atuais sem comprometer a capacidade do planeta e atender a demanda das gerações futuras, numa afirmação da finitude dos recursos naturais. Durante a Cúpula Mundial sobre o Desenvolvimento Sustentável da ONU, na África do Sul em 2010, esse conceito foi expandido, baseando-se então em três pilares: desenvolvimento econômico, desenvolvimento social e proteção ambiental (ONU, 2015). 


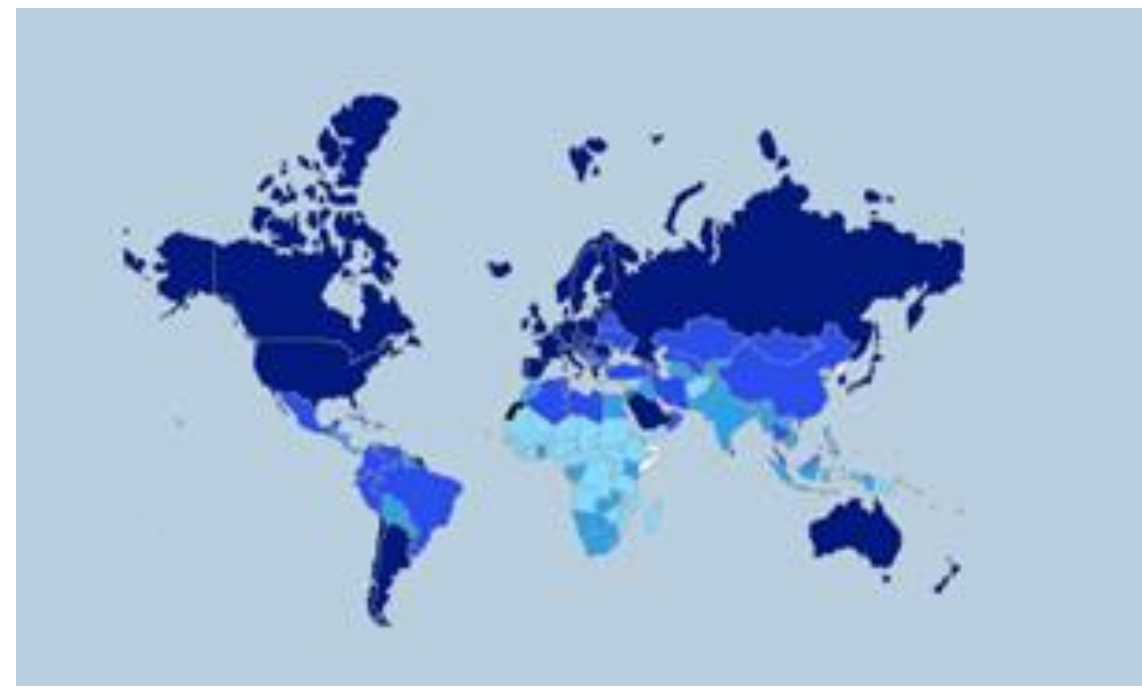

Muito alto desenvolvimento humano

Alto desenvolvimento humano

Médio desenvolvimento humano

Baixo desenvolvimento humano

Figura 2.3: Índice de Desenvolvimento Humano Global.

Fonte: UNPD (2018).

A médica Gro Harlem Brundtland, em 1983, convidada a presidir a Comissão Mundial sobre Meio Ambiente e Desenvolvimento, trouxe uma visão da saúde além do mundo médico, fazendo conexões com o meio ambiente e o desenvolvimento humano. Em 1987, é divulgado o relatório Brundtland, trazendo à pauta práticas para desenvolvimento sustentável, além de dados sobre aquecimento global, destruição da camada de ozônio e metas para que as nações colaborassem para evitar o avanço do desequilíbrio ambiental (PENSAMENTO VERDE, 2018)

Não é válido avaliar o desenvolvimento pelo PIB, principalmente nas sociedades com características de desigualdade, países onde pequena minoria da população detêm a grande maioria da renda, e a maioria da população é pobre, parecendo que são dois mundos diferentes. Uma forma de avaliar a desigualdade na distribuição de renda é o Índice de Gini, calculado a partir da curva de Lorentz, que mede o quanto a distribuição de renda ou consumo desvia de uma distribuição perfeita, igualitária. Variando entre zero e um (situação mais desigual). O Brasil, segundo dados de 2015, possui índice de Gini 0,515, colocando-se como o nono país mais desigual do mundo na distribuição de renda (UNDP, 2018). 
A desigualdade no Brasil foi socialmente construída a partir da condição de Colônia de Portugal, em 1500. O padrão produtivo baseado no latifúndio, a escravidão, as alianças políticas conservadoras para manter o sistema agroexportador e a burguesia industrial que surgiu, perpetuaram um sistema desigual, onde a força de trabalho era mais importante que a escolaridade para a grande maioria. Uma economia voltada para interesse das elites, que até hoje mostra seus sinais nas regiões norte e nordeste do país, numa nação onde a política econômica e política social nem sempre caminham juntas (SANTOS, 2017).

A desigualdade regional vai se desenhando à medida que a capital do país se transfere da região nordeste (Salvador) para o sudeste (Rio de Janeiro), concentrando riqueza e poder para a região. Apesar dos inúmeros recursos naturais distribuídos por todo o país, as distâncias continentais, a dificuldade de comunicação dos primeiros tempos, a presença da Família Real e o desenvolvimento da economia nos tempos do Império, acentua os contrastes do Brasil (SANTOS, 2017).

O país enfrentou muitas dificuldades econômicas nas últimas duas décadas do século XX, com alta inflação e endividamento, o que penalizou muito a população pobre. Houve melhora dos índices no início do século XXI, mas a corrupção e muitas medidas equivocadas mergulham o Brasil numa crise que já dura anos. Embora seja um país com muitos recursos naturais e humanos, trata-se de um país de pobres. A herança de injustiça social de uma sociedade excludente, tem ainda como desafio permitir acesso a parte de sua população às condições mínimas de dignidade e cidadania. A instabilidade econômica e política teve seus efeitos, ora positivos, ora negativos, fazendo os indicadores de pobreza oscilarem. Se a partir do ano 2000 os programas sociais aumentaram a distribuição de renda, a situação político-econômica dos últimos anos fez o país regredir (BARROS et al, 2000; SANTOS, 2017)

Considerando os cenários entre 1990 e 2015, percebe-se um aumento no índice brasileiro. Desse modo, atualmente em $79^{\circ}$ lugar (IDH: 0,754), o país integra o grupo de países com alto índice de desenvolvimento humano. A evolução pode ser vista na Fig. 2.4. Entretanto, ainda que a estatística geral seja positiva, a análise por município atesta o quanto é expressiva a desigualdade no país (UNDP, 2018).

O Índice de Desenvolvimento Humano Municipal (IDHM), índice que ajusta o IDH à realidade dos municípios, reflete desafios e especificidades regionais, e acaba por expor as discrepâncias em território nacional. Criado em 1998, o índice utiliza fonte de dados e metodologia diferenciada para cálculo de alguns indicadores que compõe o mesmo, não sendo 
assim possível comparar IDH e IDHM. Desse modo, entre os 5.565 municípios, dados de 2010 mostram em um extremo, Melgaço (PA) com IDHM de 0,418, enquanto o outro extremo apresenta São Caetano do Sul (SP) com índice de 0,862, superando em 0,118 a média brasileira (PNUD, 2014; PNUD, 2010).

As desigualdades são percebidas ao analisar que existem 40 municípios classificados com muito alto desenvolvimento e todos eles situam-se nas regiões Sul, Sudeste e Distrito Federal. São 32 municípios classificados como muito baixo desenvolvimento situados todos nas regiões Norte e Nordeste. Um outro olhar comparativo traz que o Estado de São Paulo detém IDH de 0,783. Considerado alto desenvolvimento, ocupa a segunda posição entre os Estados do país. Das 20 cidades com maior IDHM, 11 situam-se nesse Estado. A Bahia por sua vez, está em $22^{\circ}$ lugar entre os Estados da Federação, com IDH 0,660 - considerado médio desenvolvimento (PNUD, 2010). O BREA, na parte do estudo que coube ao Brasil, analisou o potencial de aproveitamento da biomassa residual nos 40 municípios com os menores IDHM, todos nas regiões Norte e Nordeste do país (GNESD, 2015).

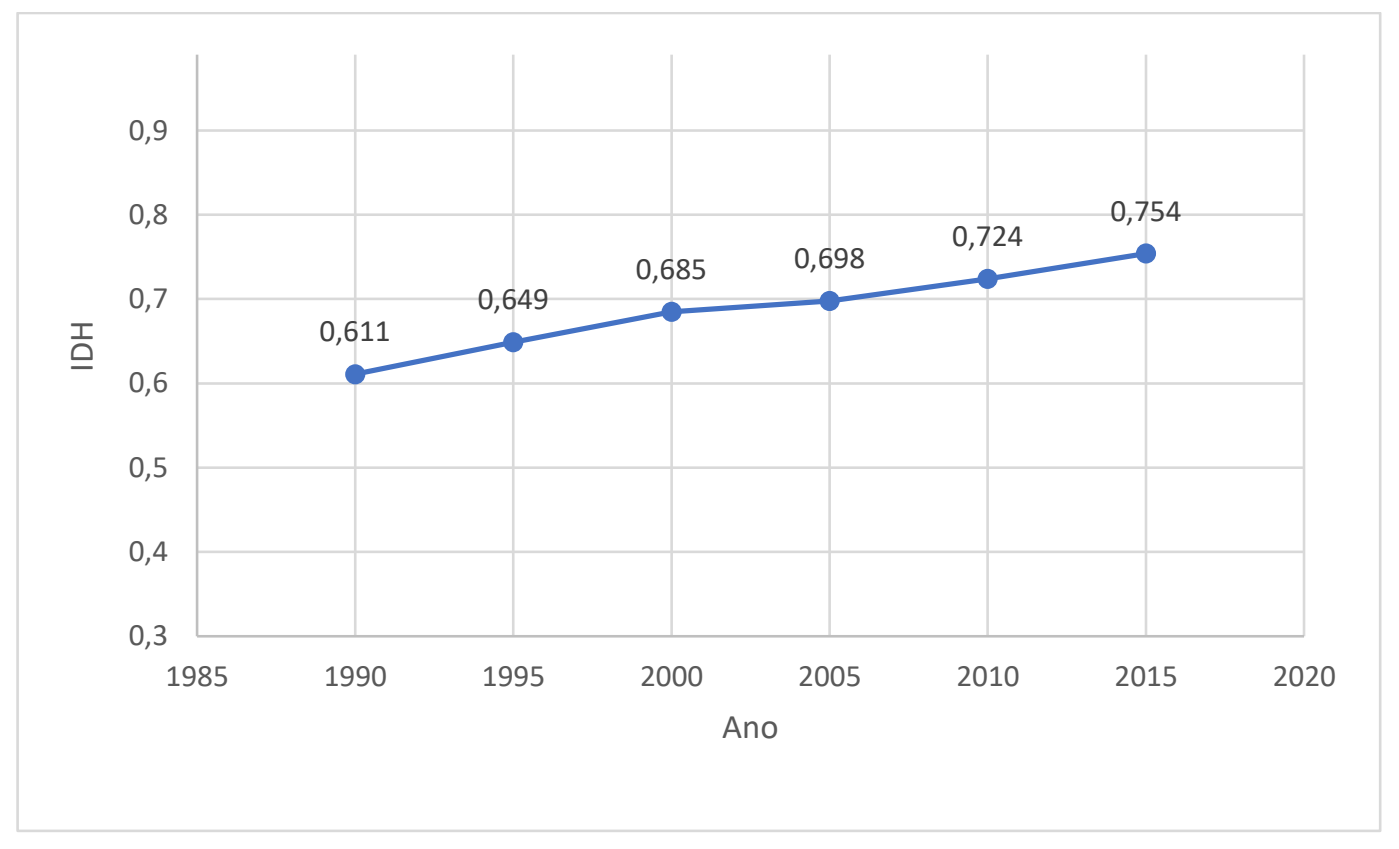

Figura 2.4: Evolução do Índice de Desenvolvimento Humano Brasil.

Fonte: UNPD (2018). 


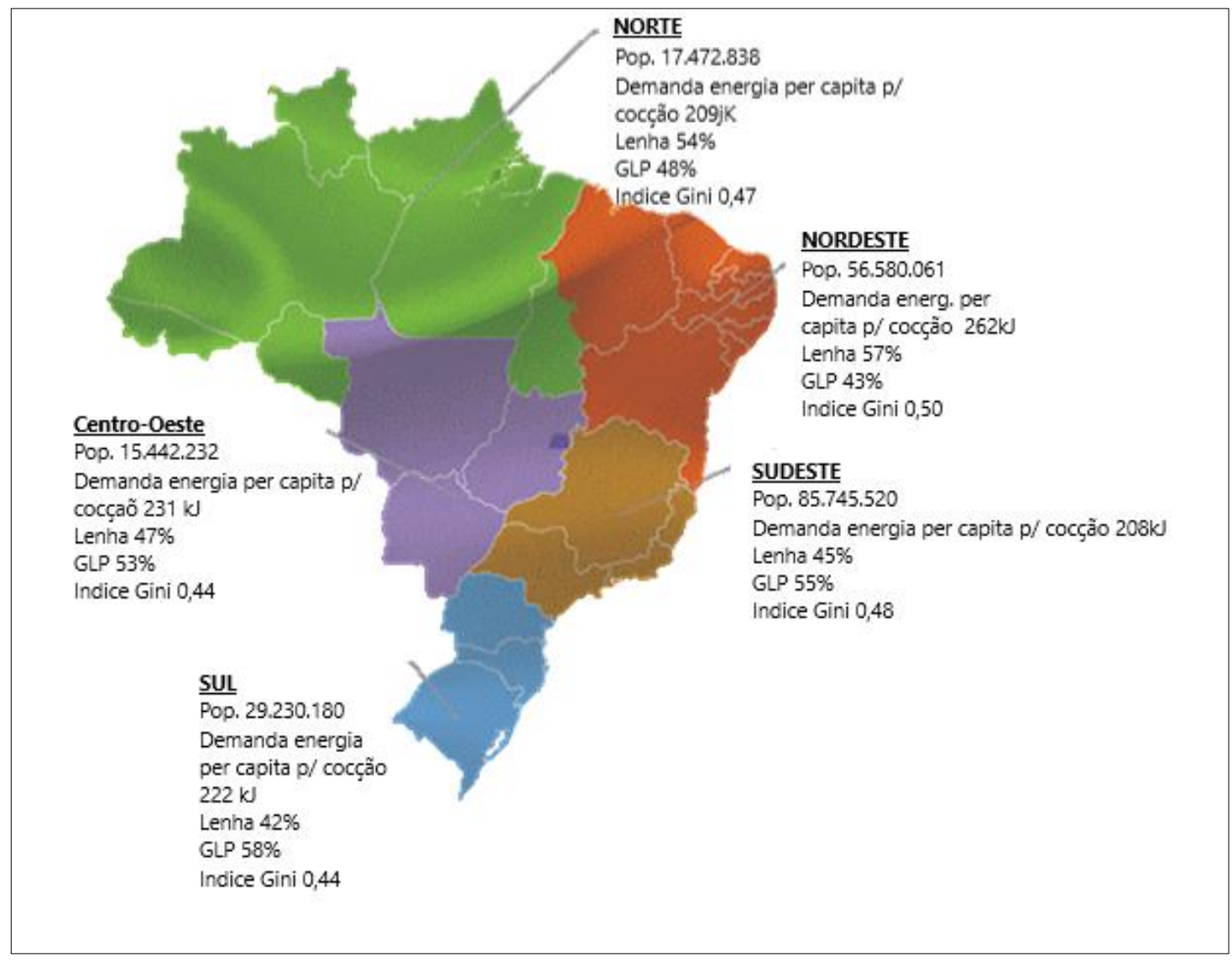

Figura 2.5: Desigualdades entre as regiões do Brasil

Fonte: COELHO et al (2015)

Outra forma de ver a desigualdade no Brasil é ilustrada pela figura 2.5, onde mostra a energia per capita para cocção e a fonte energética utilizada para tal. Percebe-se que regiões menos favorecidas se utilizam de lenha em maior quantidade, enquanto regiões mais desenvolvidas fazem uso de fonte limpa de energia, no caso GLP (gás liquefeito de petróleo).

Em 2000, a Organização das Nações Unidas (ONU) propôs medidas para erradicação da pobreza extrema e melhoria das condições de vida no planeta, conhecidas como Objetivos de Desenvolvimento do Milênio. O documento propunha, com a cooperação global, metas para serem atingidas até 2015. Oito objetivos internacionais, apresentados na tabela $2.1 \mathrm{e}$ contemplando temas percebidos como fundamentais para o desenvolvimento humano sustentável foram propostos, e indicadores foram definidos para acompanhamento e avaliação das ações a nível global, nacional e regional (ONU, 2000). 
Tabela 2.1: Objetivos de Desenvolvimento do Milênio

\begin{tabular}{|l|}
\hline 1 - Erradicar a extrema pobreza e a fome \\
2- Atingir o ensino básico universal \\
3 - Promover a igualdade de gênero e a autonomia das mulheres \\
4 - Reduzir a mortalidade infantil \\
5 - Melhorar a saúde materna \\
6 - Combater o HIV/AIDS, a malária e outras doenças \\
7 - Garantir a sustentabilidade ambiental \\
8 - Estabelecer uma parceria mundial para o desenvolvimento \\
\hline
\end{tabular}

Fonte: ONU (2000)

O ano de 2015 surge como um marco para acompanhamento e revisão desses objetivos, doravante chamados de Objetivos de Desenvolvimento Sustentável (ODS). O grande desafio para a implementação dos 17 Objetivos, apresentados na figura 2.6, necessita da participação ativa e global, incluindo governos, sociedade civil, setor primado, academia, mídia e das Nações Unidas. Os objetivos norteiam as ações para promover prosperidade e bem-estar às populações, erradicar a pobreza, proteger o meio ambiente e enfrentar da melhor forma as mudanças climáticas (ONU, 2015).
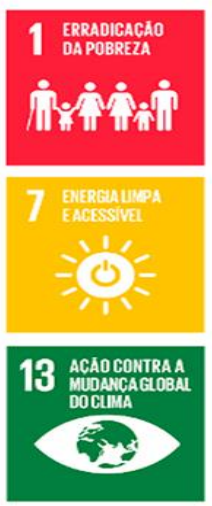
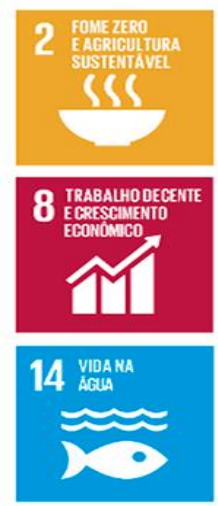
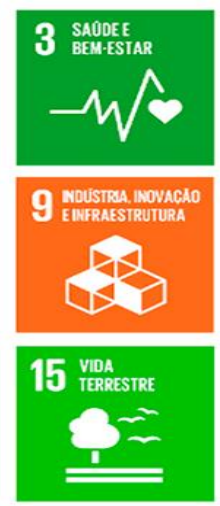
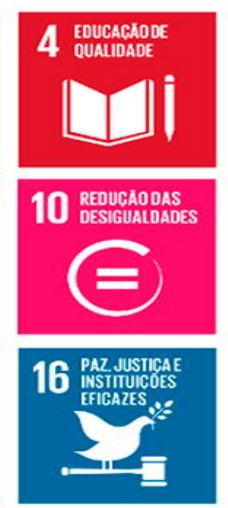
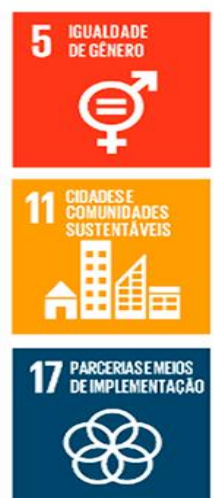
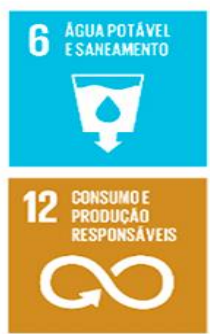

(6)

OBJETIVOS DEDESENVOVIMENTO

Figura 2.6: Objetivos de Desenvolvimento Sustentável.

Fonte: ONU (2015). 
Em livro publicado em 1988, Goldemberg e colaboradores traçam a situação energética da época, com os padrões de usos finais vigentes, e discutem uma situação futura desejável até 2020 para promover objetivos básicos envolvendo meio ambiente sadio, paz e justiça social, eficiência econômica e sustentabilidade. O estudo propunha melhoria nas condições com aumento da oferta de energia além do mínimo para países em desenvolvimento, com a elevação da eficiência energética e introdução de novos aproveitamentos energéticos da biomassa (HELENE \& CERQUINHO, 1989).

O Global Energy Assessment, publicação de 2012 coordenada pelo Prof. Dr. José Goldemberg, discutiu uma agenda de política energética global, identificando a evolução do uso e a dependência que a sociedade tem da energia para enfrentar os desafios crescentes do século XXI. A substituição de energia humana e animal e da biomassa tradicional por combustíveis fósseis encaminhou de forma violenta a humanidade para um desenvolvimento que ressaltou as desigualdades já estabelecidas e criou novas (IIASA, 2012).

Tratando-se de ingrediente essencial para o desenvolvimento, a dependência entre IDH e energia é confirmada pelo fato de que, das Metas de Desenvolvimento do Milênio, mais da metade tem participação direta da energia. Ainda como mostrado por Goldemberg (1998), há correlação entre energia comercial per capita de alguns países e alguns indicadores sociais como taxa de analfabetismo, mortalidade infantil, expectativa de vida e fertilidade total.

A energia, direta ou indiretamente, tem relevante papel para o alcance dessas metas. Contudo, temos 1,2 bilhão de pessoas ( $16 \%$ da população) no mundo que não têm acesso à eletricidade e 2,7 bilhões de pessoas ( $38 \%$ da população) que, ainda hoje, utilizam da biomassa tradicional como fonte de energia para aquecimento e preparo da alimentação, situados principalmente na África Subsaariana e Oceania, predominantemente em áreas rurais (REN21, 2017).

Com a proposta de chamar para a discussão governos, sociedade civil e setor econômico, a iniciativa denominada Energia Sustentável para Todos (SE4ALL) coloca que o acesso à energia é indispensável para o cumprimento das metas do milênio (SE4ALL, 2011).

\subsection{DESIGUALDADE NO BRASIL E NO MUNDO}

Atingir os 17 ODS só será possível caso o mundo se implique em combater e reduzir as desigualdades: de renda, de oportunidades, de gênero, culturais, entre os países e dentro deles, como no caso do Brasil. A Agenda 2030 para o Desenvolvimento Sustentável busca formas de 
promoção da prosperidade e bem-estar social, sem, contudo, continuar com as agressões ao meio ambiente.

O crescimento das economias do Sul e Leste da Ásia reduziu a desigualdade de renda entre os países, mas África Subsaariana, partes da Ásia, Caribe e América Latina continuam com indicadores muito baixos, reforçando a desigualdade mundial. Análises das Nações Unidas demonstram que 47 economias em desenvolvimento tiveram estagnação ou decaimento em sua situação atual. Segundo o Situação e Perspectivas Econômicas Mundiais 2019, são países dependentes de commodities, muitos com conflitos internos e instabilidade política, onde o desafio de desenvolver infraestrutura essencial, erradicação da pobreza, geração de empregos e diversificação da economia só cresce (ONU, 2019).

O crescimento do PIB nesses países, por si só, não deve representar melhoria nos padrões de vida, embora desempenho econômico insatisfatório tenha estreita relação com investimentos insuficientes para saúde e educação de qualidade, proteção social e mitigação dos problemas climáticos. Um país que experimenta desigualdade promove exclusão e fragmentação social, instigando o crescimento da violência. Segundo a ONU, se não houver mudança significativa, aproximadamente $7 \%$ da população global (30\% nos países menos desenvolvidos) permanecerá na pobreza até 2030. Medidas integradas e transversais são essenciais para um mundo mais sustentável e inclusivo (ONU, 2019).

O Brasil, embora estando entre as 10 maiores economias mundiais, tem a maior concentração de renda desse grupo. Pesquisa de Desigualdade Mundial em 2018 retrata que 1\% da parcela mais rica da população detém quase $30 \%$ da renda do país. A falta de acesso não se restringe à renda, mas a praticamente todo acesso a direitos, bens e serviços, como bens de consumo, saneamento básico, energia, educação, saúde, moradia. Os pobres continuam invisíveis pelos indicadores e diluídos nas estatísticas. A desigualdade aqui tem gênero e cor (CAMPELLO et al, 2018).

Políticas voltadas para desenvolvimento juntamente com estabilidade econômica são fundamentais, e aliadas à educação de qualidade, ao cuidado à saúde, inclusão digital, investimentos em transporte, agricultura, comunicação e acesso à energia, fundamentam o desenvolvimento sustentável a longo prazo. Medidas para erradicação da pobreza só fazem sentido se comprometidas com a redução da desigualdade. 


\subsection{EDUCAÇÃO, RENDA E SAÚDE}

\subsubsection{Educação}

Educação consiste num processo contínuo de transferência de saberes. Assim, conhecimentos científicos bem como hábitos, costumes e valores de uma sociedade são transferidos entre as gerações. Através da educação um indivíduo adquire capacidade de exercer uma função nos contextos sociais, culturais, políticos e econômicos de uma comunidade. No Brasil, tem-se dois níveis de educação: a básica (educação infantil, ensino fundamental e médio / técnico) e superior.

O pensamento de Paulo Freire coloca que a sociedade é promotora da desigualdade que se desdobra nos níveis econômico, político, social cultural e educacional. Defensor de uma educação emancipadora, o processo ensino-aprendizagem, de forma contextualizada, acima de tudo deveria ensinar o indivíduo a pensar, instrumentalizando-o para uma condição mais justa e igualitária (KOHAM, 2019).

A desigualdade na educação pode ser percebida através da figura 2.7, que mostra o percentual de alfabetizados nos diversos países do mundo. A alfabetização é a base para toda educação. A leitura é a ferramenta utilizada para abrir a janela do entendimento do mundo.

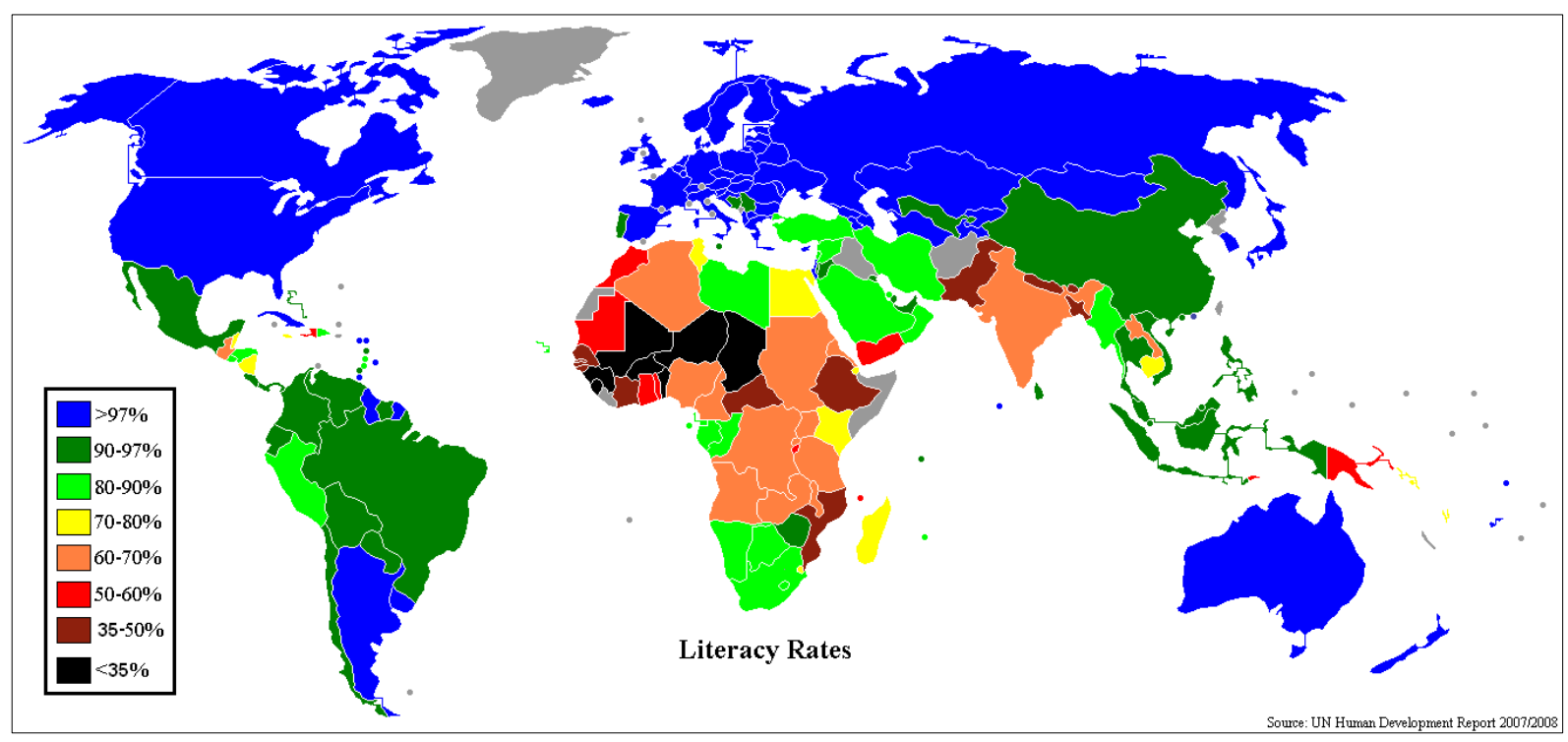

Figura 2.7: Taxa de alfabetização no mundo (\%).

Fonte: UN Human Development Report 2007/2008 (UNDP, 2008). 
Outra forma de ver a desigualdade é por meio da quantidade de anos de escolaridade média em alguns países. A tabela 2.2 traz a relação entre IDH e escolaridade, mostrando os três primeiros lugares no ranking de IDH, os Estados Unidos como parâmetro por ser a maior economia mundial, o Chile, país mais bem colocado na América do Sul, o Brasil, e os três últimos colocados nos dados atualizados pelo Human Development Report Office 2018 (UNDP, 2018).

Tabela 2.2: Média de tempo de escolaridade (anos) em alguns países (2018)

\begin{tabular}{|c|c|c|}
\hline Ranking IDH & País & Média de escolaridade (anos) \\
\hline 01 & Noruega & 12,6 \\
\hline 02 & Suíça & 13,4 \\
\hline 03 & Austrália & 12,9 \\
\hline 13 & Estados Unidos & 13,4 \\
\hline 44 & Chile & 10,3 \\
\hline 79 & Brasil & 7,8 \\
\hline 187 & Sudão do Sul & 4,8 \\
\hline 188 & República Centro & 4,3 \\
\hline & Africana & 2,0 \\
\hline
\end{tabular}

Fonte: preparado pela autora com dados do HD Report Office (2018)

Embora a desigualdade seja clara, a escolaridade tem feito progressos. Em 1990, a média de escolaridade mundial para população de adultos era 5,8 anos e em 2017 subiu para 8,4. Porém é preciso que mais tempo na escola represente melhor qualidade na educação (UNDP, 2018). O preparo dos educadores é fundamental como também o número de professores nas escolas primárias. O aproveitamento dos alunos tem relação direta com o número de professores. Quanto mais alunos em cada sala de aula, pior será o desempenho e o processo de aprendizagem.

As diferenças são observadas na figura 2.8, que relata o número de alunos por professor na escola primária, agrupando os países por nível de IDH. Não pode ser coincidência que, à medida que o IDH diminui, aumenta o número de alunos por professor. Mais educadores, oferecendo maior atenção aos alunos, provavelmente oferecem uma educação de maior qualidade. Embora os dados coloquem o Brasil no grupo de alto IDH, no ciclo básico a média 
de alunos por sala fica acima de 20 conforme os indicadores educacionais nacionais (INEP, 2019).

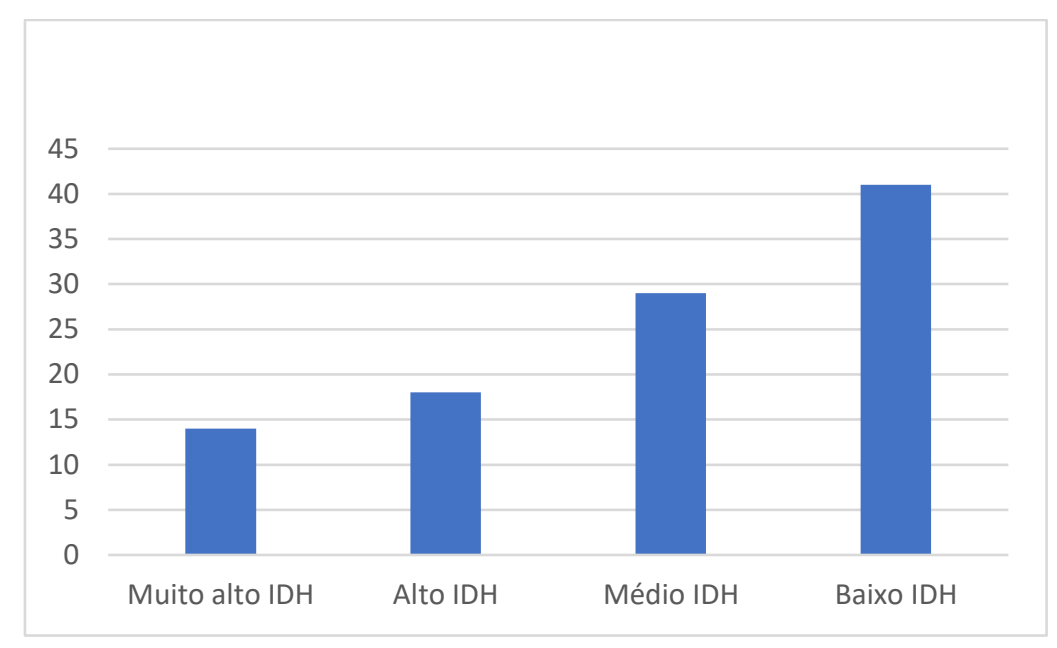

Figura 2.8: $\mathrm{N}^{\circ}$ de alunos por professor em escola primária conforme IDH.

Fonte: preparado pela autora baseada em Human Development Statistical Update (2018).

Além dos dados apresentados, a disponibilidade de novas tecnologias no ensino tem implicações na qualidade da educação. As tecnologias de comunicação são ferramentas que facilitam uma educação de excelência, mas a infraestrutura requer investimentos significativos na modernização de escolas, um grande desafio para países em desenvolvimento.

No Brasil, nos últimos anos, os indicadores de educação também têm evoluído. A taxa de analfabetismo em 2018 ficou em 6,8\%, com ligeiro decréscimo em relação ao ano anterior. Mas na Bahia são 12,7\% e em São Paulo, 2,6\%, números que reforçam as desigualdades regionais. A meta do Ministério de Educação e Cultura - MEC é erradicar o analfabetismo até 2024. Paulistas têm, em média 10,4 anos de estudo contra 7,9 entre os baianos (IBGE, 2019).

O Estado tem investido em programas para jovens e adultos, mas esse percentual não demonstra a realidade pois há um número significativo de brasileiros que são "analfabetos funcionais", pessoas que mesmo sabendo ler e escrever coisas simples, não oferece competência necessária para as demandas diárias e viabilizar seu desenvolvimento profissional e pessoal. $\mathrm{O}$ indicador de analfabetismo funcional (INAF) aponta que $29 \%$ da população está nessa classificação (INSTITUTO PAULO MONTENEGRO, 2018). Isso é retrato da baixa qualidade do ensino no país.

A figura 2.9 mostra a desigualdade, através do Índice de Desenvolvimento da Educação Básica (IDEB), apurado pelo Ministério da Educação e Cultura desde 2007. Os dados 
apresentados são de 2017. A variação pode ser entre 0 e 10, sendo que o Brasil tem como meta atingir 6,0 até 2021 (INEP, 2019).

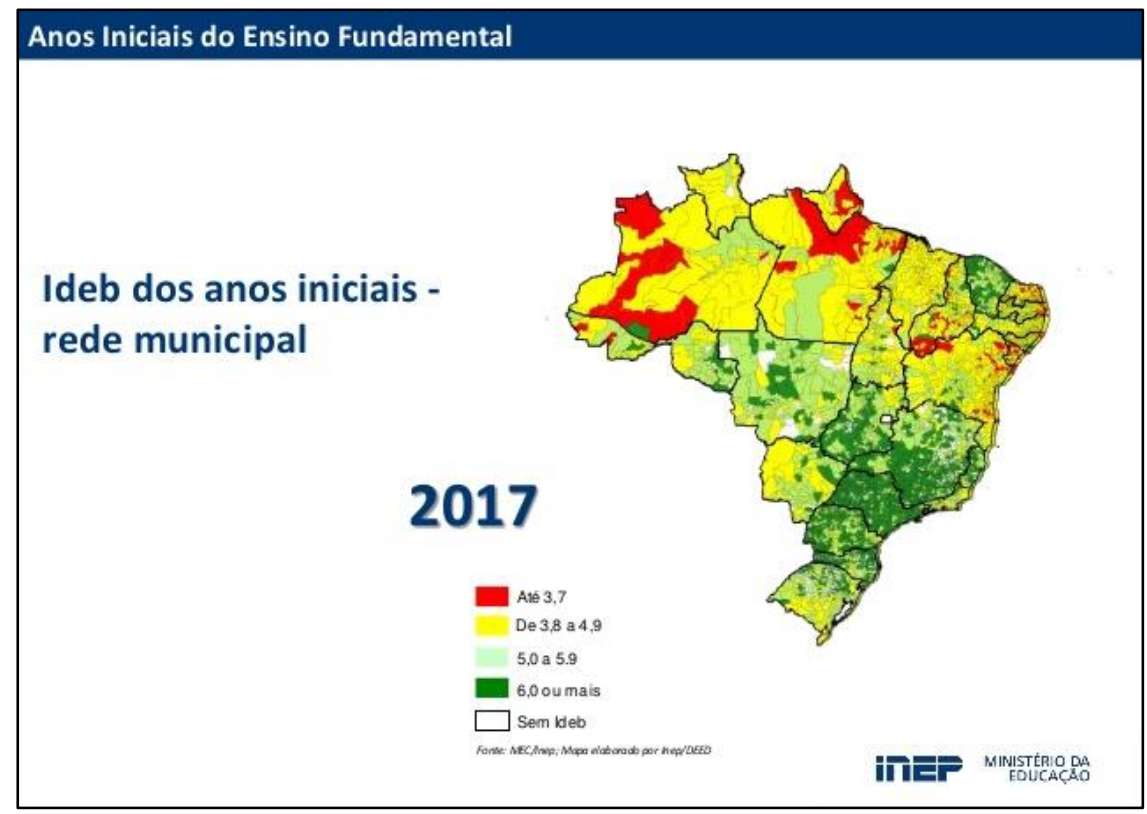

Figura 2.9: IDEB no Brasil - anos iniciais da rede municipal.

Fonte: INEP (2019).

As desigualdades no Brasil não param aí. Embora a maioria da população se declare parda (44\%) e preta (19\%), dentre brasileiros de 15 a 64 anos que se declaram brancos, 4\% são analfabetos e entre pardos ou pretos a proporção é 7 e $11 \%$, respectivamente. Segundo o Índice de Analfabetismo Funcional (INAF), 25\% dos brancos atingem ou superam o nível superior enquanto essa taxa é de $15 \%$ entre os pardos e $12 \%$ entre os pretos (INSTITUTO PAULO MONTENEGRO, 2018).

A fim de concluir esse panorama educacional brasileiro, ressaltando as desigualdades, a Pesquisa Nacional de Domicílios por Amostra Contínua (PNAD Contínua), em 2018, apontou que 47,4\% dos brasileiros com 25 anos ou mais concluíram a educação básica obrigatória. Mas essa taxa é de 38,9\% no Nordeste e de 53,6\% no Sudeste do país. Com relação a gênero, 49,5\% são mulheres e 45\% são homens e, considerando a raça, 55,8\% são brancos e 40,3\% são pretos ou pardos, ratificando a desigualdade instalada no Brasil (IBGE, 2019).

\subsubsection{Renda}

Renda refere-se à importância recebida por pessoa física ou jurídica, como remuneração de trabalho, aluguel de bens móveis e imóveis, aplicações financeiras, prestação de serviços 
entre outros. Há várias formas de mensuração das riquezas de uma região. Uma delas é o PIB, que representa a soma total de bens e serviços produzidos em determinada região e período. Se dividido pelo número de habitantes, tem-se o PIB per capita, outra forma de avaliação que considera a população do local.

Indicadores econômicos nem sempre são traduzidos em bem-estar e qualidade de vida das populações, mas uma região sem renda não consegue fazer os investimentos necessários para o alcance da qualidade de vida.

No mundo, o PIB per capita é bastante variável conforme vê-se na Figura 2.10.

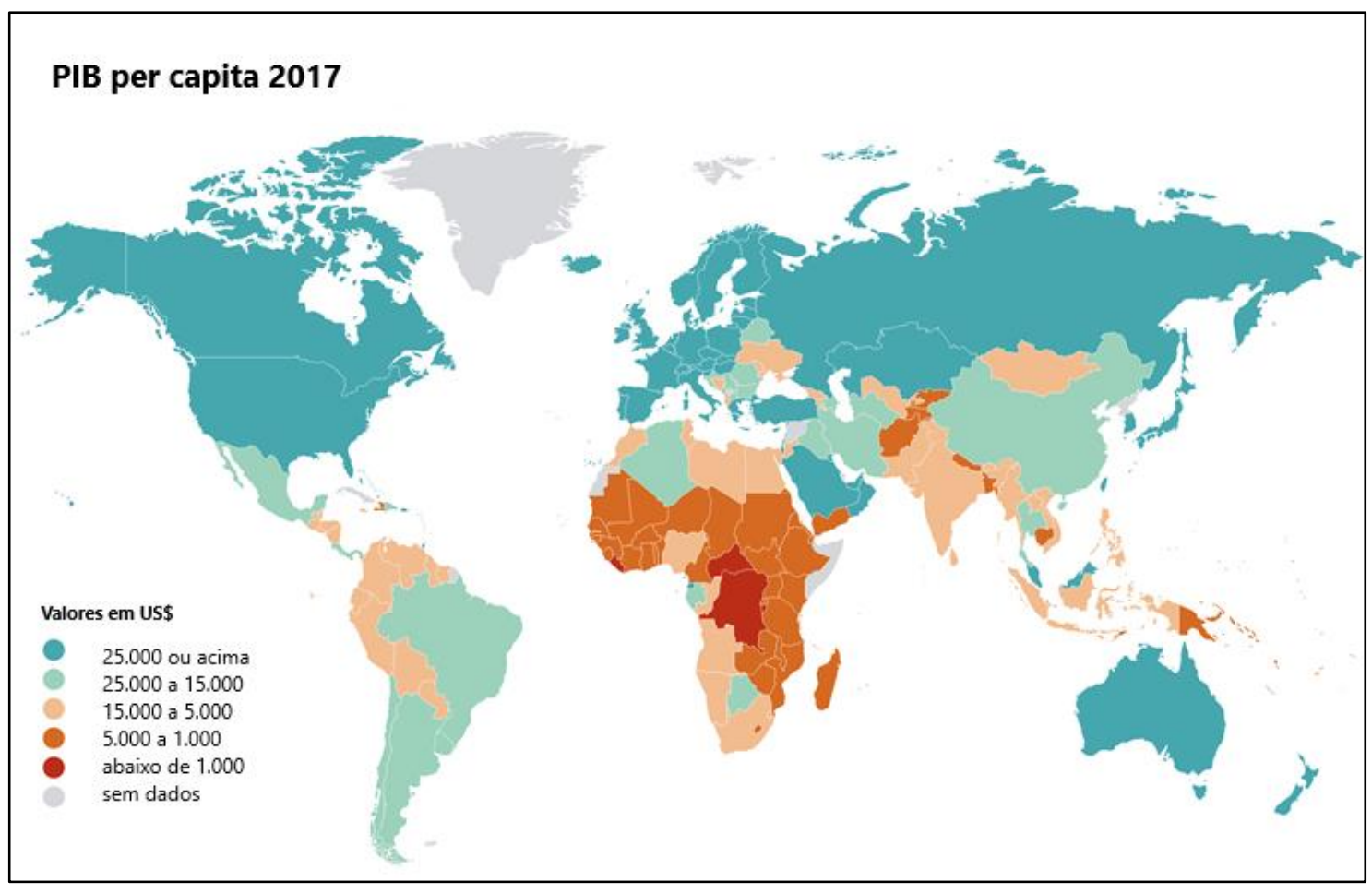

Figura 2.10: PIB per capita no mundo - 2017.

Fonte: IMF - Internacional Monetary Fund (2019).

A Organização Internacional do Trabalho mostra que, embora o desemprego global esteja em declínio, as condições de trabalho não melhoraram em 2018 e, mais de 3 bilhões de pessoas com empregos no planeta não possuíam níveis adequados de segurança econômica e bem-estar material, evidenciando que ser assalariado nem sempre significa ter padrão de vida decente. Em 2018, mais de 700 milhões de pessoas vivem em extrema ou moderada pobreza, apesar de possuírem emprego. A influência de novas tecnologias e do envelhecimento da população constituem novos desafios para aumento da renda do povo (ILO, 2019). 
Políticas públicas de trabalho, emprego e renda devem ser voltadas para o desenvolvimento justo, economicamente viável e ambientalmente sustentável, de forma a possibilitar vida digna através do próprio trabalho, garantindo a cidadania aos membros da sociedade. Crescimento econômico não é condição suficiente para geração de emprego e renda, bem como emprego e renda não são suficientes para o desenvolvimento socialmente justo (URANI, 1995).

A PNAD Continua 2017 constatou que 10\% da população com os maiores rendimentos no país concentravam $43,3 \%$ da massa de rendimentos enquanto os $10 \%$ com menor rendimento detinham apenas $0,7 \%$. No Brasil, o rendimento médio mensal real de todos os trabalhos da população ocupada era, em 2017, R \$2.178,00. A desigualdade é vista no nosso país por região: nordeste - $\mathrm{R} \$ 1.509,00$ e sudeste - $\mathrm{R} \$ 2.425,00$; por gênero: homens - $\mathrm{R} \$ 2.410,00$ e mulheres - $\mathrm{R} \$ 1.868,00$; e por raças: brancos - $\mathrm{R} \$ 2.814,00$, pardos - $\mathrm{R} \$ 1.606,00$ e pretos $-\mathrm{R} \$ 1.570,00$. Considerando o percentual da população com rendimento proveniente de trabalho, o Nordeste possui $34,7 \%$, o Sudeste 45,2\% e a média nacional está em 41,9\%. A PNAD Contínua de 2017 apontou relação positiva entre renda e instrução, denotando a interligação dos indicadores (IBGE, 2018).

Essa mesma pesquisa divulgou que a taxa de desocupação no trimestre que se encerrou em junho 2019 ficou em 12\%, com ligeiro recuo, mas isso significa que 12,8 milhões de brasileiros continuam na lista dos desempregados. A desigualdade mais uma vez é vista pois, esse índice em SP é 13,8\% e na BA, 17,3\%. A desigualdade também se apresenta com relação a gênero: $10,3 \%$ de homens desocupados e 14,1\% de mulheres. Abordando a questão racial, 9,5\% dos brancos estão desocupados, $14,5 \%$ de pretos e $14 \%$ de pardos (IBGE, 2019).

\subsubsection{Saúde}

O conceito de saúde proposto pela Organização Mundial da Saúde (OMS), em 1947, define saúde como "estado completo de bem-estar físico, mental e social e não apenas ausência de doença ou enfermidade". Trata-se de um conceito multidimensional, atrelado também a questões socioculturais e geotemporais (OPAS, 2019). Trata-se de um direito social indiscutível ao se falar em cidadania, e que não deve discriminar raça, gênero, condição política ou socioeconômica.

A OMS iniciou 2019 com metas ambiciosas, onde mencionavam atender 1 bilhão a mais de pessoas nos serviços de saúde, nas emergências médicas, melhorando assim, a vida no planeta. Para tal, definiu prioridades como medidas de mitigação à poluição ambiental e às 
mudanças climáticas, e mencionou o combate de inúmeras doenças infecciosas, doenças crônicas não transmissíveis e outros desafios de saúde pública (ONU, 2019).

Sendo um tema bastante complexo, a mensuração da saúde pode ser verificada com inúmeros indicadores, entre eles mortalidade infantil, expectativa de vida, acesso ao esgotamento sanitário e água potável (com impacto direto na saúde), entre outros.

As causas da mortalidade infantil são diversas. Em relatório divulgado pela ONU em 2010 cita que, 1,8 milhões de crianças morriam por ano vítimas de doenças diarreicas, diretamente relacionadas com potabilidade da água e esgotamento sanitário inadequado ou inexistente (WORLD HEALTH ORGANIZATION \& UN-WATER (2010). Nishioka e outros (2000) publicaram estudo sobre efeitos da poluição do ar na mortalidade neonatal na cidade de São Paulo, concluindo que não só idosos e crianças, mas também recém-nascidos têm sua saúde afetada com a poluição atmosférica.

Na figura 2.11 observa-se a taxa de mortalidade infantil (em 1000 nascidos vivos) no mundo. As discrepâncias são significativas e novamente vemos regiões da África, Ásia e América Latina em situação bastante desigual se comparada a países desenvolvidos.

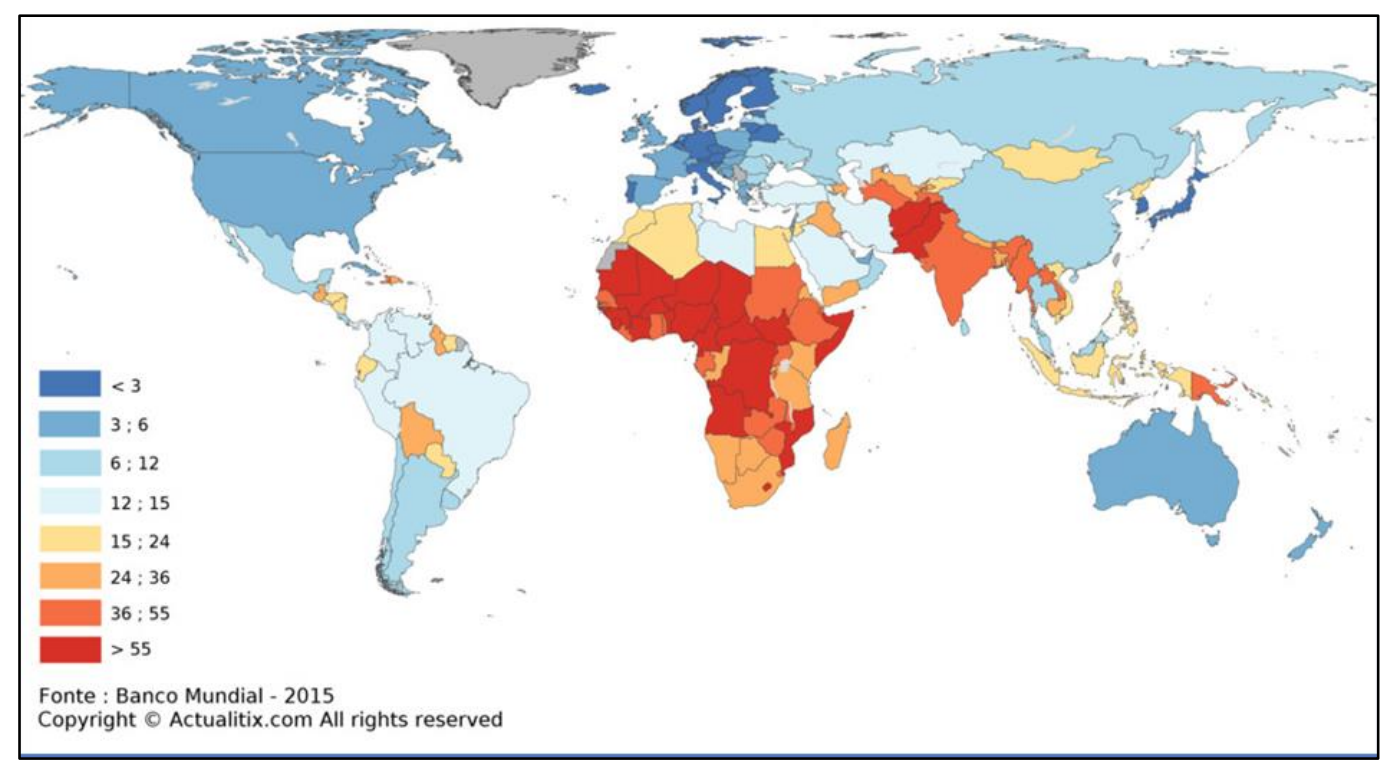

Figura 2.11: Mortalidade Infantil em 1000 nascidos vivos - 2015.

Fonte: dados do Banco Mundial em arte de Actualitix (2016).

A expectativa de vida também possibilita a visualização da desigualdade no sistema de saúde oferecido pelos diversos países do globo. A tabela 2.3 mostra expectativa de vida nos três primeiros lugares no ranking de IDH, os Estados Unidos como parâmetro por ser a maior 
economia mundial, o Chile, país mais bem colocado na América do Sul, o Brasil, e os três últimos colocados nos dados atualizados pelo Human Development Report Office 2018 (UNDP, 2018).

Tabela 2.3: Expectativa de vida (anos) em alguns países (2018)

\begin{tabular}{|c|c|c|}
\hline Ranking IDH & País & Expectativa de vida (anos) \\
\hline 01 & Noruega & 82,3 \\
\hline 02 & Suíça & 83,5 \\
\hline 03 & Austrália & 83,1 \\
\hline 13 & Estados Unidos & 79,5 \\
\hline 44 & Chile & 79,7 \\
\hline 79 & Brasil & 75,7 \\
\hline 187 & Sudão do Sul & 57,3 \\
\hline 188 & República Centro & 52,9 \\
\hline & Africana & \\
\hline 189 & República do Níger & 50,4 \\
\hline
\end{tabular}

Fonte: preparado pela autora com dados do HD Report Office 2018

A desigualdade é gritante. São mais de 30 anos de vida de diferença entre a maior e menor expectativa de vida apresentadas. Entre as causas, podemos citar insegurança alimentar, saneamento básico inadequado, serviço de saúde insuficiente, poluição ambiental, educação precária, falta de acesso a condições adequadas de higiene e moradia, violência, entre outros.

No Brasil, a Constituição de 1988, através do Art.6, estabelece a saúde, entre outros, como direito social fundamental. No Art. 196, saúde é tratada como direito de todos e dever do Estado, que deve promover o acesso universal e igualitário às ações e serviços para promoção, proteção e recuperação da saúde (BRASIL, 2016).

O país ostenta um índice de mortalidade infantil de 12,35 óbitos por mil nascidos vivos (2018), número esse que decresceu significativamente nos últimos anos. São mais de 400 mil estabelecimentos de saúde, $83 \%$ de domicílios com coleta direta de lixo (2018), 88,3\% de domicílios com disponibilidade diária de abastecimento de água da rede (2018), 66,3\% de domicílios com esgotamento sanitário (rede ou fossa séptica) (2018) (IBGE, 2019). 


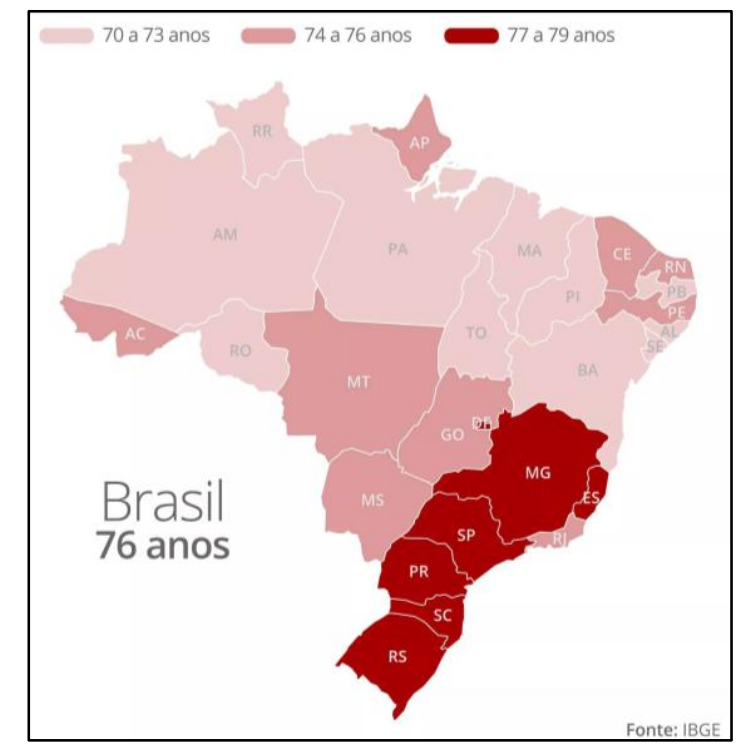

Figura 2.12: Expectativa de vida no Brasil por Estados - 2017.

Fonte: dados do IBGE (2018).

A figura 2.12 mostra a distribuição da expectativa de vida no Brasil. Região Norte e Nordeste detém os menores valores, no panorama da desigualdade nacional. Isso é explicado pelas diferentes taxas de coleta de lixo, acesso à saúde, esgotamento sanitário, qualidade da água, entre outros. Enquanto no Brasil são aproximadamente 450 pessoas por estabelecimento de saúde, em Itapicuru (BA) são 3.500 e em Ribeirão Branco (SP), 2.600. A mortalidade infantil, em ambos os casos, está bem acima da média nacional: 29,26 para a cidade baiana em estudo e 33,71 para a cidade paulista. Números mais detalhados sobre essas duas cidades são apresentados no capítulo 4, que discorre sobre os dados sociodemográficos específicos desses dois municípios.

\subsection{CONCLUSÕES DO CAPÍTULO}

A história do homem, contada sob o ponto de vista da apropriação da energia, demonstra como, ao longo do tempo, à medida que o progresso das civilizações ocorria, também se instalava a desigualdade. Os dados apresentados mostram as disparidades no mundo e no Brasil, sob o ponto de vista de alguns indicadores de educação, renda e saúde. A desigualdade no país tem raça, gênero, regionalidade, embora sejam todos cidadãos brasileiros. 


\section{QUALIDADE DE VIDA, ACESSO À ENERGIA E USO DE RESÍDUOS DE BIOMASSA COMO FONTE DE ENERGIA}

A fim de entender e inter-relacionar qualidade de vida e uso de biomassa residual como fonte de energia, é preciso primeiro explorar as definições de qualidade de vida e acesso à energia, bem como de que forma esses dois temas interagem para então prosseguir com o estudo. Este capítulo explora os conceitos de qualidade de vida e formas de mensuração, define e explica de forma sucinta como calcular o IDH e IDHM, fala sobre o acesso à energia no mundo e no Brasil e traz alternativas tecnológicas para aproveitamento energético de resíduos.

\subsection{QUALIDADE DE VIDA}

Utilizado pela primeira vez em 1964, pelo então presidente norte-americano Lyndon Johson, que defendia que objetivos deviam ser medidos pela qualidade de vida proporcionada às pessoas, o conceito começou a ser estudado pelas ciências humanas. Na área médica, o conceito esteve ligado a indicadores como diminuição da mortalidade e aumento da expectativa de vida, porém nos anos 90 houve uma proliferação de instrumentos para avaliação da qualidade de vida nos Estados Unidos, com grande discussão se haveria ou não relação com questões culturais (FLECK et al, 1999).

O conceito de qualidade de vida não possui consenso, mas possui três aspectos fundamentais: a subjetividade, a multidimensionalidade e a presença de dimensões positivas e negativas. Independente de questões espaciais, culturais ou temporais, entende-se que ter qualidade de vida é sentir-se bem, ter boas condições físicas, sentir-se socialmente integrado e funcionalmente competente. A OMS desenvolveu então, um projeto colaborativo multicêntrico para criar um instrumento de avaliação da qualidade de vida - o WHOQOL - 100, que em 1994 definiu qualidade de vida como "a percepção do indivíduo de sua posição na vida no contexto da cultura e sistema de valores nos quais ele vive e em relação aos seus objetivos, expectativas, padrões e preocupações” (WHOQOL GROUP, 1994 apud FLECK et al, 1999).

Esse assunto pode ser estudado sob vários aspectos, induzindo a uma reflexão qualitativa sobre a condição de vida individual ou coletiva. Se sua conceituação é grande desafio, sua mensuração assume caráter ainda mais pretencioso. Deve-se considerar o homem como ser biológico e social simultaneamente, analisando condições materiais e fundamentais para a vida, as formas de produção e transformação do ambiente, o desenvolvimento da sociedade e a sua relação com o Estado (ROCHA et al, 2000). 
O desenvolvimento de uma sociedade refere-se a um processo de evolução, crescimento, modificação para uma condição melhor. Muito tempo utilizou-se, para avaliar desenvolvimento, indicadores econômico-financeiros. Segundo a definição do PNUD, o desenvolvimento humano é "um processo de ampliação das escolhas das pessoas para que elas tenham capacidades e oportunidades para serem aquilo que desejam ser". Assim, em contraponto ao PIB per capita, o IDH avalia a qualidade de vida, o bem-estar proporcionado pelas riquezas, observando capacidades e oportunidades dos cidadãos (PNUD, 2019).

A seguir, discute-se um índice para mensurar a qualidade de vida, o Índice de Desenvolvimento Humano e sua metodologia.

\subsection{IDH E SUA METODOLOGIA}

O IDH pretende sintetizar várias faces sobre o tema, mas não é um índice de felicidade. Através dele, há possibilidade de se abrir debate para outras questões. São necessários outros índices e indicadores complementares, pois vários temas não são contemplados pela metodologia do IDH, como participação, sustentabilidade, equidade, entre outros. A metodologia foi otimizada ao longo dos anos e, os três pilares são mensurados como indicado a seguir, segundo PNUD (2019):

- A expectativa de vida mede uma vida longa e saudável - pilar saúde;

- A Renda Nacional Bruta (RNB) per capita expressa em poder de paridade de compra (PPP) constante, em US\$, com 2005 como referência, mede o padrão de vida da população - pilar renda;

- $\mathrm{O}$ acesso ao conhecimento tem em sua mensuração o envolvimento de alguns indicadores, a saber: a média de anos de educação de adultos (acima de 25 anos) e a expectativa de anos de escolaridade para criança (baseado na continuidade das taxas de matrículas específicas por idade) - pilar educação.

Desde 1990, quando da sua primeira publicação, o IDH teve repercussão positiva principalmente por sua simplicidade, fácil compreensão e forma abrangente de considerar o desenvolvimento, tornando-se referência mundial. Trata-se de índice chave dos Objetivos de Desenvolvimento do Milênio da ONU. São indicadores complementares do desenvolvimento humano: o Índice de Desenvolvimento Humano Ajustado à Desigualdade (IDHAD), o Índice de Desigualdade de Gênero (IDG) e o Índice de Pobreza Multidimensional (IPM) (PNUD, 2019). 
Vários países fizeram adaptações do IDH para níveis subnacionais, entre eles o Brasil, desde 1998. O Índice de Desenvolvimento Humano Municipal (IDH-M) utiliza dados do Censo Demográfico e é utilizado pelo Governo Federal e outras esferas da administração pública para a proposta de estratégias, políticas públicas e iniciativas voltadas ao desenvolvimento sustentável (PNUD, IPEA e FJP, 2013).

Com dados do Censo Demográfico do IBGE de 2010, em 2013 o PNUD Brasil, o Instituto de Pesquisa Aplicada (IPEA) e a Fundação João Pinheiro (FJP) em conjunto, calcularam o IDHM para 2010 e recalcularam o índice para 1999 e 2000. A metodologia segue as três dimensões do IDH global, fazendo adequações ao contexto nacional e aos indicadores disponíveis aqui. O Atlas do Desenvolvimento no Brasil 2013 reúne a série histórica do IDHM e outros indicadores socioeconômicos que dão suporte às análises apresentadas (PNUD, IPEA e FJP, 2013).

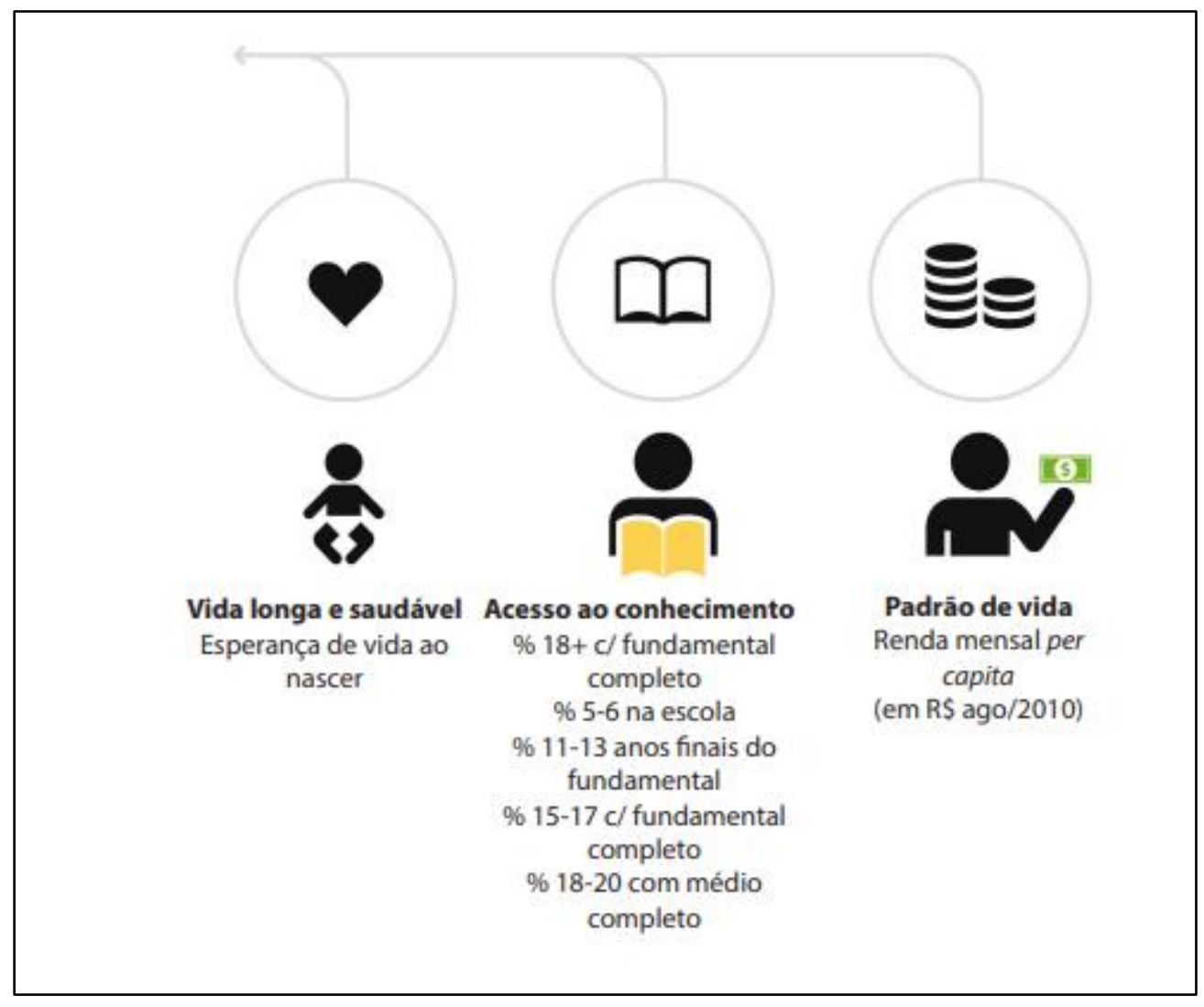

Figura 3.1: Indicadores para cálculo do IDH-M Fonte: (PNUD, 2019). 


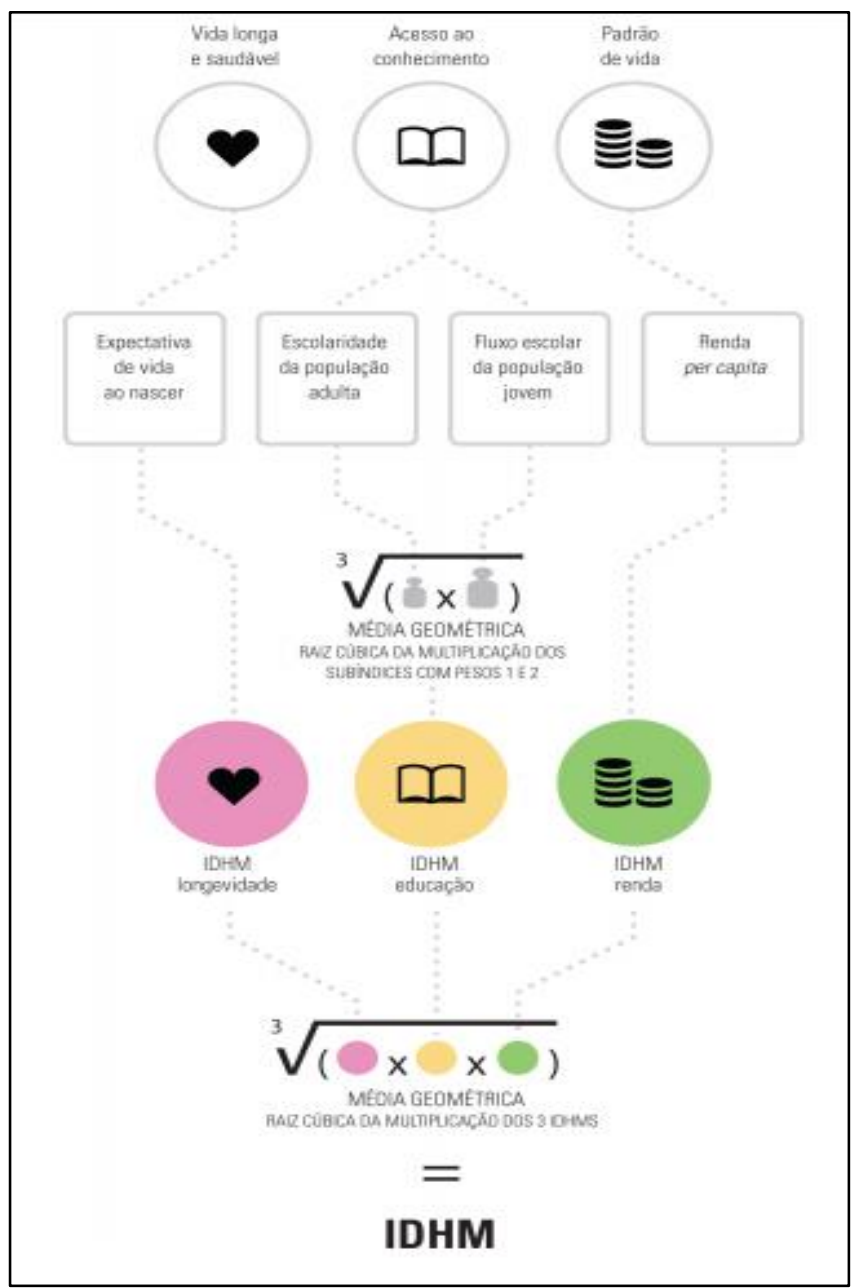

Figura 3.2: Metodologia atual cálculo do IDH-M

Fonte: PNUD, IPEA e FJP (2013).

Na figura 3.1 observam-se os três pilares para cálculo do IDHM e os indicadores considerados para tal. Na figura 3.2 há uma indicação dos cálculos utilizados para o índice em estudo. Ele é um número que, variando entre 0 e 1, pode classificar o desenvolvimento humano do município de acordo com as faixas mostradas na figura 3.3. O mapa apresentado na figura 3.4 mostra o IDHM no Brasil (2010).

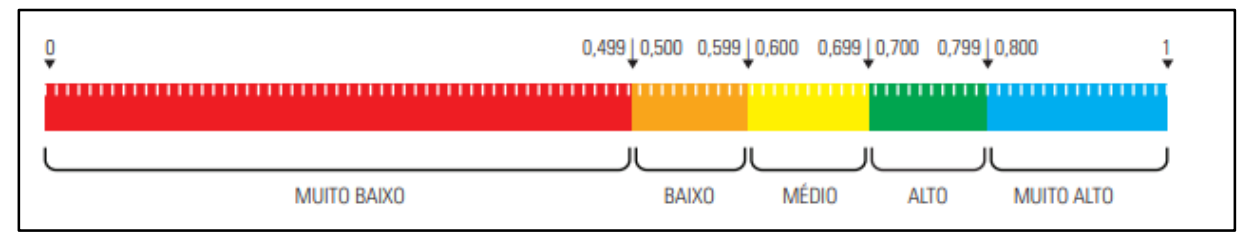

Figura 3.3: Faixas de Desenvolvimento Humano Municipal Fonte: PNUD, IPEA e FJP (2013). 


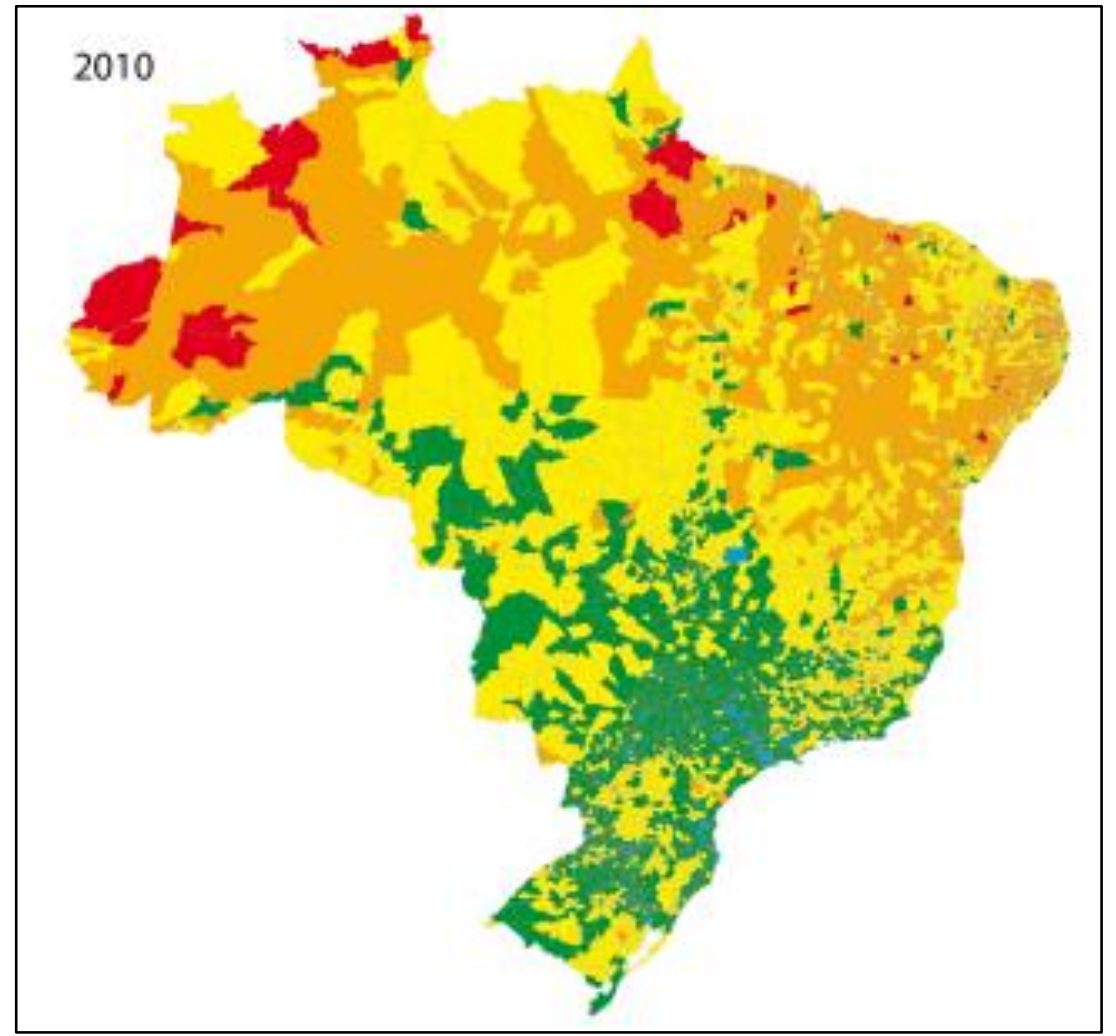

Figura 3.4: IDH-M no Brasil (2010). A legenda de cores pode ser interpretada conforme as faixas apresentadas na figura 3.3. Fonte: PNUD (2019).

\subsection{ACESSO À ENERGIA}

A definição dada pela ONU (2012) para acesso universal à energia é disponibilidade a serviços de energia limpa, confiável e acessível para cocção, aquecimento, iluminação, comunicações e uso produtivo. Esse acesso se refere à possibilidade de uso da eletricidade, bem como a combustíveis modernos (gás liquefeito de petróleo - GLP e gás natural - GN entre outros) para cocção e aquecimento, em detrimento à biomassa tradicional (COELHO \& GOLDEMBERG, 2013).

O Direito de Acesso à Energia faz parte do Direito ao Desenvolvimento, um desdobramento dos Direitos Humanos (DH) previsto na Declaração Universal de 1948, e, segundo Costa (2009) é pré-condição e meio para exercício de vários DH’s como Direito à vida, moradia, trabalho, água, alimento e inclusão digital.

Segundo Goldemberg (1998), a energia é um ingrediente essencial para o desenvolvimento e tem impacto em indicadores sociais. Marcando os vinte anos da realização 
da Conferência das Nações Unidas sobre Meio Ambiente e Desenvolvimento (Rio-92), a Rio+20, Conferência das Nações Unidas sobre Desenvolvimento Sustentável, realizada em 2012, teve como objetivo a ratificação do compromisso político com o desenvolvimento sustentável, verificando progressos e avaliando novos temas sobre o assunto. Na ocasião, foi reconhecido o papel crítico da energia no desenvolvimento e que o acesso às formas de energia moderna apresenta forte contribuição na erradicação da pobreza, poupando vidas, melhorando a saúde, ajudando assim a prover as necessidades humanas básicas (ONU, 2012).

A oferta de energia deve ser discutida sob diferentes pontos de vista: uma coisa é ter energia para cobrir necessidades básicas, como para iluminação, cocção e aquecimento, que demanda entre 50 e $100 \mathrm{kWh}$ per capita por ano. A partir dessa fase, as pessoas começam a demandar por mais energia para satisfazer outras necessidades advindas do desejo por máquinas e equipamentos alimentados à energia, como utensílios domésticos e aparelhos para comunicação entre outros, sendo o aumento dessa demanda então um novo problema a ser solucionado. A demanda para energia "produtiva", utilizada para processos agrícolas e irrigação, produção de artesanato, alimentos regionais entre outros consome entre 500 e 1000 kWh per capita por ano (COELHO et al., 2015).

\subsubsection{Acesso à energia no mundo}

O acesso à energia é o caminho que une desenvolvimento humano, sustentabilidade ambiental e crescimento econômico. As fontes de energia, comerciais (quando há transação comercial envolvida) e não-comerciais (obtidas com gratuidade) são várias, sendo que a biomassa tradicional (madeira, lenha, carvão vegetal, resíduos agrícolas, resíduos orgânicos de animais e urbanos) esteve presente desde os primórdios da humanidade e até hoje participa como fonte energética para cocção e aquecimento devido à acessibilidade e baixo custo, para aproximadamente um terço da população mundial mais pobre (GOLDEMBERG \& LUCON, 2012; REN21, 2017).

Apesar da diminuição do número de pessoas sem acesso à eletricidade no mundo, em 2016 esse número estava em 1,1 bilhão de pessoas, principalmente na África Subsaariana. A tabela 3.1 mostra o percentual da população mundial sem acesso à eletricidade no mundo e em algumas regiões com a situação crítica (IEA, 2017). 
Tabela 3.1: População sem acesso à eletricidade em percentual.

\begin{tabular}{|l|c|c|}
\hline & $\mathbf{2 0 0 0}$ & $\mathbf{2 0 1 6}$ \\
\hline África & 66 & 48 \\
\hline Ásia em & 33 & 11 \\
desenvolvimento & & \\
\hline América Latina & 14 & 3 \\
\hline Mundo & 27 & 13 \\
\hline
\end{tabular}

Fonte: IEA, 2017

O acesso à eletricidade, anteriormente proveniente do uso de combustíveis fósseis, tem mudado desde 2012 com o crescimento da utilização de fontes renováveis, onde tecnologias com custo decrescente e mais eficientes têm sido procuradas por usuários finais, modificando o panorama do acesso à energia principalmente nas áreas rurais (IEA, 2017).

Um dos usos importantes para a energia é a cocção, pois a alimentação é atividade fundamental para existência humana. Dados globais mostram que 2,8 bilhões de pessoas não tem acesso à combustíveis modernos (eletricidade, gás liquefeito de petróleo, gás natural) para cocção, chamada de cocção limpa, utilizando-se de lenha, resíduos agrícolas, esterco seco entre outros. A tabela 3.2 mostra o percentual da população mundial sem acesso à cocção com combustíveis modernos no mundo e em algumas regiões com a situação crítica (IEA, 2017).

Tabela 3.2: População sem acesso à cocção limpa em percentual.

\begin{tabular}{|l|c|c|}
\hline & 2000 & 2015 \\
\hline África & 76 & 71 \\
\hline Ásia em desenvolvimento & 65 & 49 \\
\hline América Latina & 19 & 12 \\
\hline Mundo & 46 & 38 \\
\hline
\end{tabular}

Fonte: IEA (2017)

\subsubsection{Acesso à energia no Brasil}

O programa Luz Para Todos (LPT), lançado pelo Governo Federal em 2003, pretendia promover acesso à eletricidade a populações rurais (aproximadamente dois milhões de habitantes) até 2008. Com as dificuldades encontradas, o programa foi prorrogado para término em 2011 e posteriormente para 2018. Resultados oficiais mostram um percentual de mais de 
99\% da população urbana e 15,6 milhões de moradores de zonas rurais com acesso à energia elétrica, com 92,9\% dos beneficiados do programa relatando aumento na qualidade de vida, ratificando a percepção sobre o tema (BRASIL - MME, 2017). Oliveira (2013) discute como o Programa LPT, um exemplo a nível internacional, trata o acesso à energia como tendo um peso crítico no desenvolvimento econômico para minimizar a pobreza energética que, segundo ele, é um flagelo mundial.

Partindo do acesso à eletricidade, é possível proporcionar níveis adequados de iluminação, água potável, cuidados com a saúde, comunicação além de educação e renda. Existe relação entre pobreza e falta de acesso à eletricidade. Assim, o Governo Federal lançou programas de eletrificação rural ao longo do tempo, antes do LPT, isso por se tratar da população mais vulnerável para essa exclusão. O País teve o Programa de Desenvolvimento Energético de Estados e Municípios (PRODEEM) em 1994 e o Luz no Campo em 1999. A reforma do setor elétrico no país não favoreceu o acesso à eletricidade em regiões rurais e de baixa renda, regiões remotas onde as fontes renováveis podem aparecer como opções viáveis, maximizando o desenvolvimento sustentável (GOLDEMBERG et al, 2004).

Considerando-se o uso residencial, os três principais energéticos são a eletricidade (46\%), GLP $(26,5 \%)$ e a lenha $(24,4 \%)$. Embora o acesso à energia elétrica na área urbana seja quase a totalidade, a eletricidade quase não é utilizada para cocção, onde o GLP é predominante. Dados da Pesquisa do Orçamento Familiar POF 2008-2009 indicavam que 92\% dos fogões das áreas urbanas eram alimentados a GLP e apenas 39\% na área rural, onde a lenha ainda era utilizada para cocção por questões culturais e econômicas. Porém com a deterioração da condição econômicas das famílias e desemprego nos últimos anos, dados de 2018 indicavam 14 milhões de famílias brasileiras (aproximadamente 20\%) cozinhando com lenha ou carvão. Nota-se que poluição do ar em ambientes fechados, como ocorre muitas vezes em residências, é sério fator de risco para morbi-mortalidade (GIODA et al, 2019).

A figura 3.5 mostra a energia consumida para cocção considerando o tipo de combustível, entre 2000 e 2013. Nele, vê-se com é significativo o uso de biomassa tradicional para cocção.

O uso de biomassa tradicional para cocção em equipamentos muitas vezes rudimentar, propicia a combustão incompleta gerando partículas e componentes que trazem danos à saúde. Essa prática é observada principalmente entre populações de baixa renda, vivendo em condições de vulnerabilidade. 


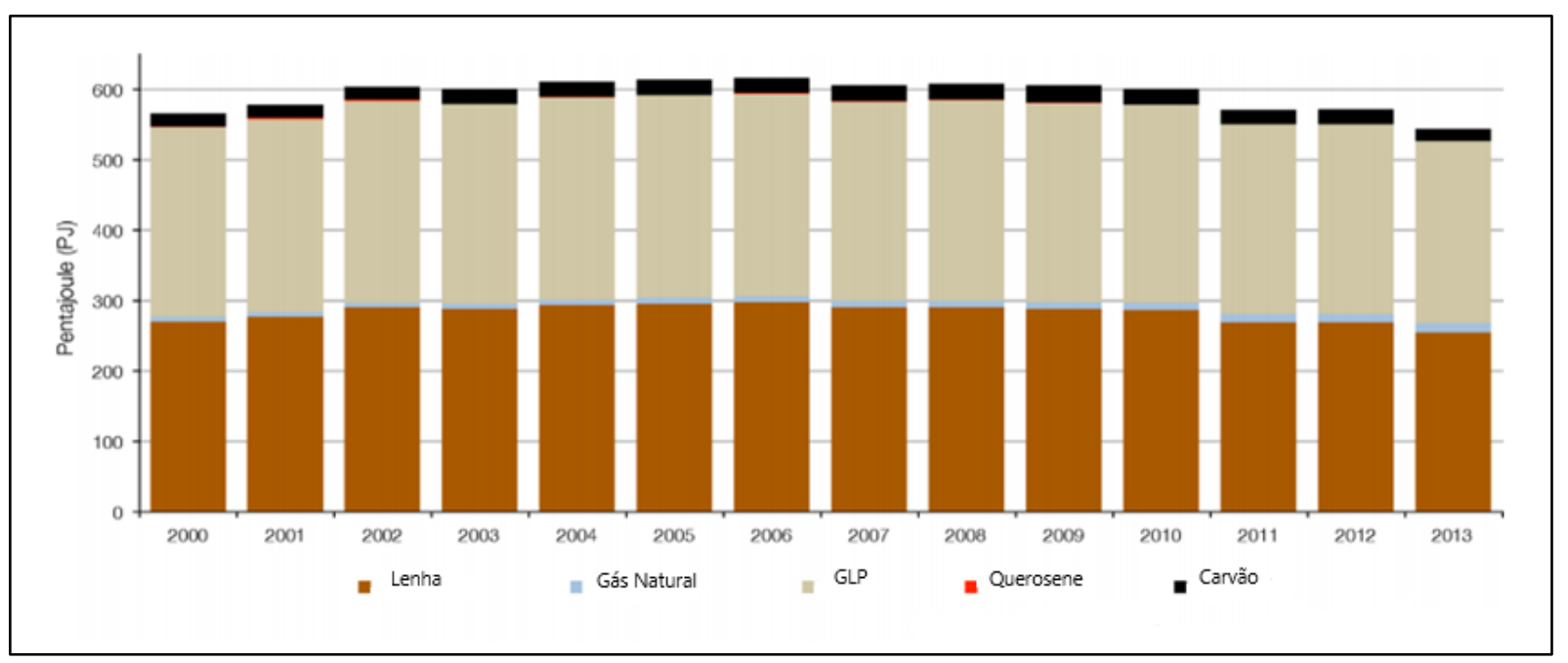

Figura 3.5: Energia consumida para cocção em residências por tipo de combustível entre 2000 e 2013.

Fonte: Sanches-Pereira, Tudeschini e Coelho (2016).

A biomassa "moderna" (biogás de aterros, bioetanol, biodiesel) por sua vez, também é fonte renovável de energia, sendo que a utilização de resíduos através de tecnologias aperfeiçoadas coloca a biomassa residual (proveniente de resíduos agrícolas e orgânicos, rurais e urbanos) como importante fonte para geração alternativa de energia, devido ao seu custo quase nulo (resíduos são subprodutos de outros processos) e disponibilidade por serem gerados em meio urbano (material de aterros, resíduos de podas, esgotamento sanitário, entre outros) ou rural ( resíduos agrícolas e dejetos de animais) (GOLDEMBERG \& LUCON, 2012).

\subsection{BIOMASSA RESIDUAL COMO FONTE DE ENERGIA}

De uma forma geral, resíduos urbanos, de acordo com a ABNT NBR 10.004:2004, podem ser sólidos ou semissólidos e são provenientes de várias fontes como atividades industriais, comerciais, domiciliares, hospitalares, varrição e poda, entre outros. Trata-se de todo material, substância, objeto ou bem descartado resultante de atividades humanas em sociedade, sendo que muitos desses resíduos são constituídos de biomassa, massa biológica proveniente de matéria viva (ABNT, 2004).

No caso de resíduos sólidos urbanos, a Lei 12.305, de 2 de agosto de 2010, instituiu a Política Nacional de Resíduos Sólidos (PNRS), sujeita à observância de pessoas físicas ou jurídicas geradoras de resíduos sólidos, e que tem como objetivos a proteção da saúde pública e qualidade ambiental, estímulo à adoção de padrões sustentáveis de produção e consumo, não geração, redução, reutilização, reciclagem e tratamento de resíduos sólidos, gestão integrada de resíduos entre outros (BRASIL, 2015). 
Porém, passados vários anos, os dados do Brasil mostram que a geração de Resíduos Sólidos Urbanos (RSU) continua crescente, atingindo em 2018 aproximadamente 217 mil toneladas/dia, com $92,01 \%$ desse resíduo coletado (98,07\% no sudeste e $81,08 \%$ no nordeste), tendo 73,1\% dos municípios do país com iniciativas de coleta seletiva ( 89,7\% no sudeste e 54,5\% no nordeste). Desse total de RSU gerado, 59,5\% são dispostos em aterros sanitários, $23 \%$ em aterros controlados e 17,5\% ainda vão parar no lixão. No Brasil, 1.493 municípios ainda mantêm lixões como destino do resíduo gerado (207 no Sudeste e 844 no Nordeste) (ABRELPE, 2019).

Há também os resíduos rurais (agrícolas e animais), na maioria não utilizados e frequentemente descartados deforma inadequada (corpos d’agua, queimados ou deixados no campo).

A disposição desses materiais, tanto urbanos como rurais, torna-se de difícil equacionamento, principalmente para municípios pequenos e sem recursos para seu tratamento e disposição adequada, causando invariavelmente problemas como contaminação dos recursos hídricos e do solo, além de serem propícios à propagação de agravos à saúde (GOUVEIA, 2012).

Assim, a utilização de biomassa residual, além de possibilitar a geração complementar de energia, corroboraria na disposição desses resíduos que são potenciais agentes causadores de problemas ao ecossistema (PAVAN, 2010), sendo então uma possível solução para municípios pobres melhorarem seus indicadores de qualidade de vida, entre eles seu IDHM.

A figura 3.6 mostra a energia primária no mundo, por fonte. Embora a biomassa tenha sido o primeiro material energético a ser utilizado pela humanidade (e ainda tem sua importância para várias populações), sua utilização fica próximo de $10 \%$ na energia primária total no mundo. Na América (países não pertencentes a Organização para Cooperação e Desenvolvimento Econômico - OECD) esse percentual é de 21\% (IEA, 2019). A produção de eletricidade através da biomassa não é significativa, mas tem sido bastante considerada devido à minimização de impactos ambientais e pressões sociais para uso racional de insumos energéticos. A geração de eletricidade proveniente da biomassa está baseada em resíduos, utilizados muitas vezes no próprio local onde são disponibilizados (WALTER \& NOGUEIRA, 2008). 


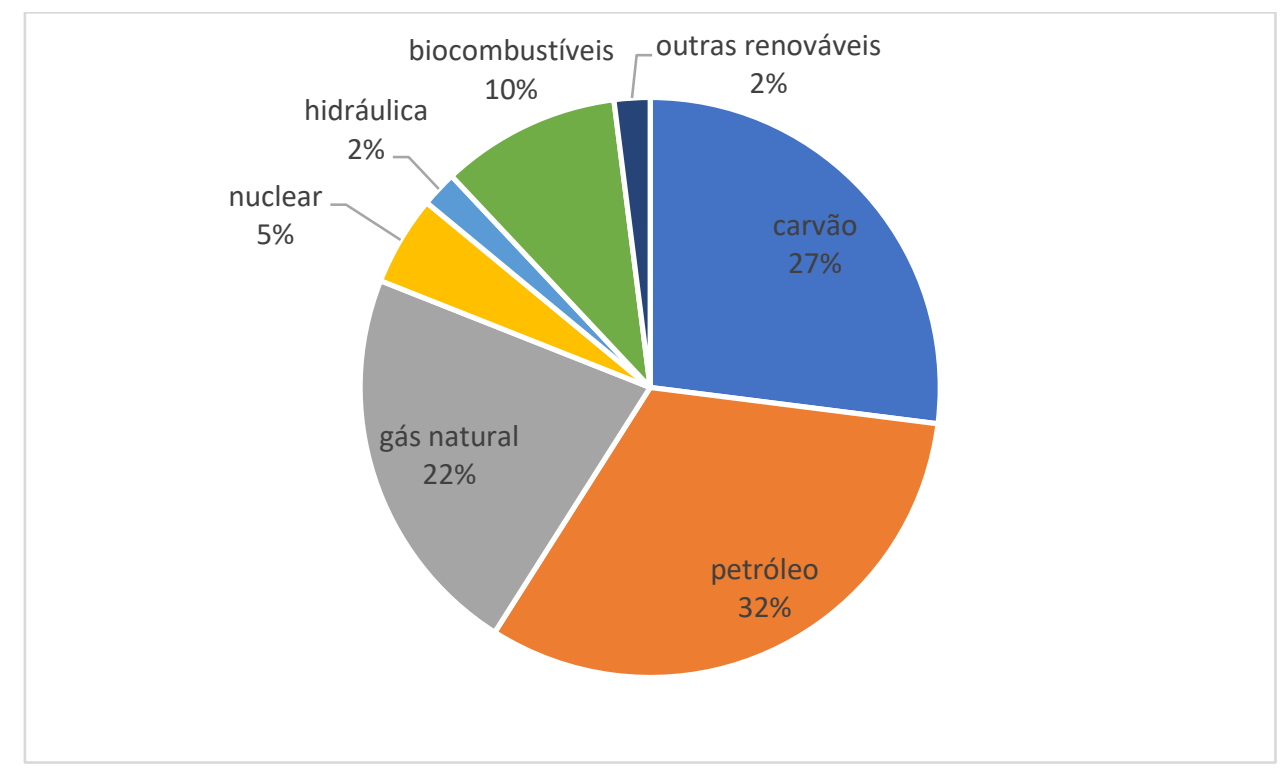

Figura 3.6: Energia primária total no mundo por fonte (2017) em percentuais.

Fonte: IEA (2019).

O uso da biomassa para geração de eletricidade tem como principais vantagens as baixas/nulas emissões de gases efeito estufa (principalmente se for residual), melhores práticas agroindustriais, geração de empregos, diversificação da matriz energética entre outros. Por outro lado, é preciso avaliar os custos de produção e transporte da biomassa até o local da geração de energia (caso não sejam os mesmos), as limitações tecnológicas decorrentes da eficiência de conversão energética da biomassa envolvida que pode ser tão baixa a ponto de comprometer a viabilidade econômica, e, por fim, a questão da sustentabilidade envolvida no processo, olhada sob o ponto de vista ambiental, social e econômica (WALTER \& NOGUEIRA, 2008).

Ainda sobre a utilização da biomassa como fonte energética em residências, em países menos desenvolvidos a biomassa tradicional é mais utilizada (lenha catada ou desmatada, resíduos de animais secos ou gás e biodigestores domésticos). Já nos países mais desenvolvidos, o consumo da biomassa provém das florestas energéticas (lenha replantada). A termoeletricidade utilizando biomassa moderna (lenha replantada ou culturas energéticas como cana-de-açúcar) deve ser avaliada de acordo com o ciclo de vida e as tecnologias empregadas (GOLDEMBERG \& COELHO, 2004; GOLDEMBERG \& LUCON, 2012).

O uso da biomassa residual para aproveitamento energético está completamente alinhado ao cenário mundial na busca de alternativas renováveis. A modificação do destino final dos resíduos conduz à menor quantidade disposta em aterros ou em locais inapropriados, reduzindo 
a necessidade de área para novos aterros, diminuição do lixiviado gerado, evitando contaminação de corpos d'água. O Brasil, país com forte vocação para o setor agropecuário, tem na utilização de resíduos (agrícolas, dos dejetos de animais criados em confinamento e agroindústrias associadas) grande oportunidade de obtenção de energia renovável reduzindo a dependência de combustíveis fósseis e diminuindo impacto ambiental causado pelos mesmos (IPEA, 2012).

A utilização da biomassa residual para geração de energia complementar em municípios com baixo IDHM foi foco de estudo realizado pelo projeto BREA - Biomass Residues as Energy Source to Improve Energy Acess and Local Economic Activity in Low HDI Regions of Brazil and Colombia. Trata-se de projeto financiado pelo GNESD - Global Network in Energy for Sustainable Development, situado na Dinamarca, e foi executado numa parceria entre o Grupo de Pesquisa em Bioenergia - Gbio (IEE/USP), o Instituto Alberto Luiz Coimbra de PósGraduação e Pesquisa de Engenharia (COPPE/UFRJ), o Centro Brasileiro de Energia e Mudanças Climáticas (CBEM), o Instituto Energia e Desenvolvimento Sustentável (INEDES) e com a Universidad de La Sabana (Colômbia) (GNESD, 2015).

O objetivo principal deste estudo foi conhecer de forma mais aprofundada as necessidades energéticas com fins produtivos em famílias de baixa renda, nas regiões de menor desenvolvimento humano tanto no Brasil como na Colômbia. Partindo do levantamento da disponibilidade de biomassa urbana e rural, buscou-se traçar possibilidades para e geração de energia a partir desses resíduos (através de combustão direta, gaseificação e digestão anaeróbica), permitindo eletrificação e melhoria das atividades produtivas locais, impactando positivamente o desenvolvimento humano desses municípios estudados (GNESD, 2015).

O relatório final do BREA identificou dificuldades econômicas, políticas e geográficas entre outras para a aplicação dessas tecnologias na geração de energia a partir da biomassa residual, embora tenham sido apontadas como propostas para contribuir com elevação de IDH permitindo maior acesso à energia para usos produtivos, redução na emissão de $\mathrm{CO}_{2}$ e melhor disposição do lixo (GNESD, 2015). Não houve, entretanto, verificação in loco da realidade das comunidades e as condições para validação de tecnologias de conversão em pequena escala dos resíduos disponíveis para a geração de energia estudadas. Outra questão a esse respeito é que o relatório não teve a oportunidade de ouvir das populações envolvidas a real contribuição de mais energia na qualidade de vida deles. 


\subsection{POTENCIAIS DE APROVEITAMENTO ENERGÉTICO}

O aproveitamento de fontes renováveis de energia deve ser avaliado considerando as várias classes de potenciais, conforme proposto por Resch et al (2008).

O potencial teórico considera os parâmetros físicos do processo, estimando o máximo aproveitamento energético de determinado recurso. O potencial técnico considera a eficiência de equipamentos e processos, sendo assim um potencial dinâmico de acordo com a evolução das tecnologias existentes. O potencial de realização considera o máximo potencial possível no contexto em que se insere, supondo que barreiras e limitações existentes podem ser superadas.

Nesta tese, foi considerado o potencial técnico para análise do aproveitamento energético da biomassa residual.

\subsection{TECNOLOGIAS PARA GERAÇÃO DE ENERGIA ELÉTRICA ATRAVÉS DA BIOMASSA EM SISTEMAS DE MENOR PORTE}

A biomassa tem origens diversas (animais, vegetais, industriais e florestais) e sua utilização como fonte energética apresenta diferentes tecnologias, algumas com elevada eficiência tecnológica, com flexibilidade de suprir energéticos para produção de energia elétrica e mobilidade na área de transportes. A principal fonte para gerar energia de biomassa são os resíduos, com grande potencial precisando apenas de adequada exploração. Restrições de ordem ecológicas (relacionadas ao meio ambiente e qualidade de vida), socio-políticoeconômicas e tecnológicas devem ser consideradas ao buscar-se disponibilidade e aproveitamento energético dessa biomassa (CORTEZ, LORA e GOMEZ, 2008).

A biomassa provém de vegetais não lenhosos (sacarídeos, celulósicos, amiláceos e aquáticos), vegetais lenhosos (madeiras), resíduos orgânicos (agrícolas, urbanos e industriais) e biofluidos (óleos vegetais). O Brasil, um grande produtor agrícola, vem aos poucos aproveitando resíduos gerados em larga escala, como o bagaço da cana-de-açúcar e a palha de arroz entre outros. Resíduos agroindustriais e florestais em sua maioria são aproveitados na queima direta em fornos ou caldeiras, mas existem outras alternativas como a digestão anaeróbica ou a gaseificação (CORTEZ, LORA e GOMEZ, 2008).

Nesta seção apresentamos as principais opções tecnológicas para aproveitamento energético de resíduos de biomassa, a serem discutidas a seguir. 


\subsubsection{Combustão direta}

Dentre as rotas tecnológicas que utilizam a biomassa para geração de energia, a que é baseada em ciclos a vapor necessita a queima dessa biomassa que gera vapor ao produzir calor. Esse vapor, com pressão e temperatura determinadas, é direcionado à expansão em turbinas a vapor, que acionam geradores elétricos. No sistema de cogeração, parte ou em sua totalidade, o vapor é extraído à pressão necessária para a demanda calórica. Os sistemas baseados em ciclos a vapor têm como característica geral baixa eficiência energética e deve-se indiretamente às características da biomassa (WALTER \& NOGUEIRA, 2008).

A figura 3.7 mostra esquema de ciclo a vapor (cogeração) onde vapor extraído da caldeira segue para aproveitamento térmico em estufa.

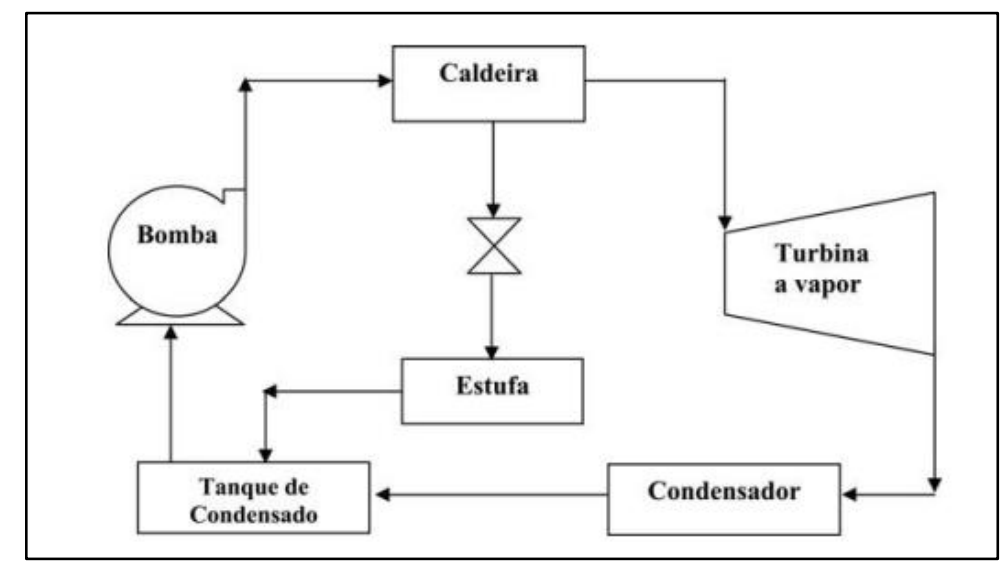

Figura 3.7: Ciclo a vapor - cogeração.

Fonte: VELAZQUEZ et al (2010).

O Projeto ENERMAD (energia da madeira), realizado em parceria entre o Ministério das Minas e Energia (MME), Conselho Nacional de Pesquisa (CNPq), Centro Nacional de Referência em Biomassa (CENBIO), Instituto de Ambiente e Energia (IEE) da Universidade de São Paulo (USP) e o Grupo de Energia, Biomassa e Meio Ambiente (EMBA) da Faculdade de Engenharia Mecânica da Universidade Federal do Pará (UFPA), proporcionou a instalação de central termoelétrica para aproveitamento de calor e geração de energia elétrica, na Vila Porto Alegre do Curumu, na Ilha de Marajó (município de Breves - PA) (VELAZQUEZ et al, 2010).

Trata-se de comunidade isolada onde principais atividades econômicas envolviam exploração e confecção de artefatos de madeira. As 2 t/dia de resíduos, serragem e aparas de 
madeiras foram então utilizadas para utilização na geração de energia elétrica e calor para secagem da madeira. O ciclo com condensador de vapor e estufa (figura 3.8) funciona desde 2009 e abastece a serraria, fábrica de vassouras, residências e a secagem para madeira - 200kW que eram supridos por geradores a diesel. A tecnologia que já era conhecida foi adaptada para pequeno porte para geração decentralizada, substituindo os $22 \mathrm{mil}$ l/mês de óleo diesel que eram utilizados até então, atendendo as necessidades dessa comunidade isolada com biomassa residual de forma sustentável (VELAZQUEZ et al, 2010).
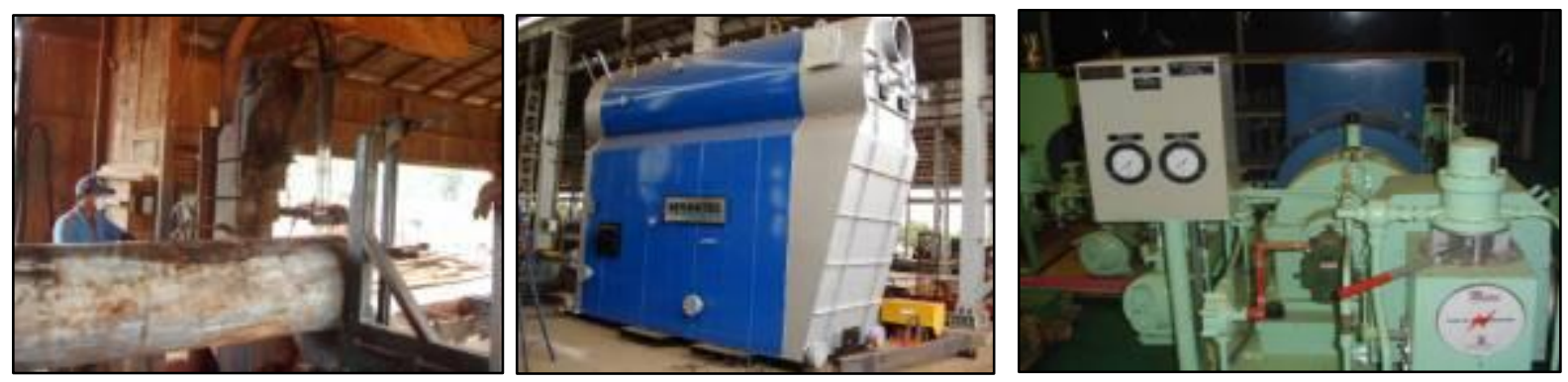

Figura 3.8: Serraria, Caldeira (SERMATEC) e Turbina / gerador (TGM).

Fonte: (VELAZQUEZ et al, 2010).

\subsubsection{Digestão anaeróbica}

Processo de conversão bioquímica através da ação de microrganismos, tem como produto, entre outros, mistura gasosa - chamada de biogás, composta basicamente de metano $\left(\mathrm{CH}_{4}\right)$ e dióxido de carbono $\left(\mathrm{CO}_{2}\right)$, podendo apresentar gás sulfídrico $\left(\mathrm{H}_{2} \mathrm{~S}\right)$, nitrogênio $\left(\mathrm{N}_{2}\right)$ e hidrogênio $\left(\mathrm{H}_{2}\right)$ em quantidades menores. Trata-se de processo promissor na área biotecnológica pois pode utilizar materiais sólidos e líquidos, reduzindo significativamente o poder poluente dos resíduos (CORTEZ, LORA e GOMEZ, 2008).

São elegíveis para utilização na digestão anaeróbica resíduos orgânicos gerados em áreas urbanas, outros resíduos gerados a partir de atividades industriais e agroindustriais, bem como dejetos de sistemas criatórios de animais no meio rural. A porção líquida resultante do processo (efluente) pode ser aplicada como biofertilizante, ração e inseticida. Já o biogás, por possuir alto percentual de metano, é inflamável e pode ser empregado em funções termodinâmicas: geração de frio, calor e potência. No meio rural, tem sua utilização para cocção, iluminação, secagem, aquecimento (inclusive nas criações), acionamento de motores a explosão, irrigação e geração de energia elétrica (CORTEZ, LORA e GOMEZ, 2008). 
A biodigestão ocorre em quatro fases, a saber: hidrólise, acidogênese, acetogênese e metanogênese, degradando a matéria orgânica do substrato na ausência de oxigênio. A composição do biogás varia conforme as características desse substrato, temperatura e $\mathrm{pH}$ do meio, tendo em média $60 \%$ de metano. Para sua utilização, é necessário que haja um processo de purificação, a depender de sua composição e exigências tecnológicas do aproveitamento energético (COELHO, 2018).

O número de plantas de biogás tem crescido vertiginosamente. Países europeus como Alemanha e Itália estão entre os protagonistas da geração dessa energia renovável. No Brasil, a Empresa de Pesquisa Energética (EPE) cita 29 plantas para produção de energia elétrica (aterro sanitário, resíduos agroindustriais e de processo criatório animal) em 2017. Outras 5, de porte industrial, também atuavam com matéria prima resíduos de aterro sanitário, esgoto e uma com resíduos orgânicos de restaurante, poda de jardim e outros materiais orgânicos diversos, sendo ainda tímida a participação desse energético na matriz brasileira (COELHO, 2018).

A figura 3.9 apresenta um fluxograma simplificado da produção e usos finais do biometano.

Na geração de energia a partir do biogás, a energia química existente nas moléculas de metano é transformada em energia térmica ou mecânica. A energia mecânica, ao ativar um gerador faz a conversão desta em energia elétrica. Os motores ciclo Otto e as microturbinas a gás estão entre as tecnologias mais utilizadas para esse fim. A cogeração (sistema combinado de geração de calor e energia) aumenta a eficiência energética, utilizando mesmo combustível para várias aplicações simultâneas (COELHO, 2018).

No município de Marechal Cândido Rondon (PR), desde 2009, 33 propriedades rurais que produzem aproximadamente 16 mil toneladas/ano de resíduo orgânico proveniente de criação de animais fazem parte do Condomínio de Agroenergia para Agricultura Familiar Ajuricaba. Cada uma delas possui biodigestor individual, sendo parte desse biogás utilizado nas próprias unidades produtoras para cocção e esterilização de ordenhas. As propriedades são interligadas por dutos que transporta o gás excedente para uma microcentral termoelétrica, unidade de cogeração que produz energia elétrica e calor para secagem de grãos (JIE, 2012). A figura 3.10 mostra uma propriedade com biodigestor e a microcentral termoelétrica.

No total, mais de 260 mil m3/ano de biogás são produzidos, em parceria entre Itaipu Binacional, prefeitura do município e Centro Internacional de Energias Renováveis (CiBiogas) na execução, com participação do Centro Internacional de Hidroinformática, Fundação Parque 
Tecnológico de Itaipu, Instituto Paranaense de Assistência Técnica e Extensão Rural (Emater) e Empresa Brasileira de Pesquisa Agropecuária (Embrapa). Com a implementação desse projeto apresentado na Reunião do Projeto Hidrológico Internacional da Unesco durante a Rio+20 como caso de sucesso, alguns resultados importantes foram atingidos como aumento e diversificação da produção agrícola, melhoria da qualidade de vida das populações envolvidas pela redução de insetos e odores, segurança energética com geração de receita adicional e mitigação de problemas decorrentes da poluição de solo e água entre outros (PLATAFORMA DE BOAS PRATICAS PARA O DESENVOLVIMENTO SUSTENTAVEL, 2019).

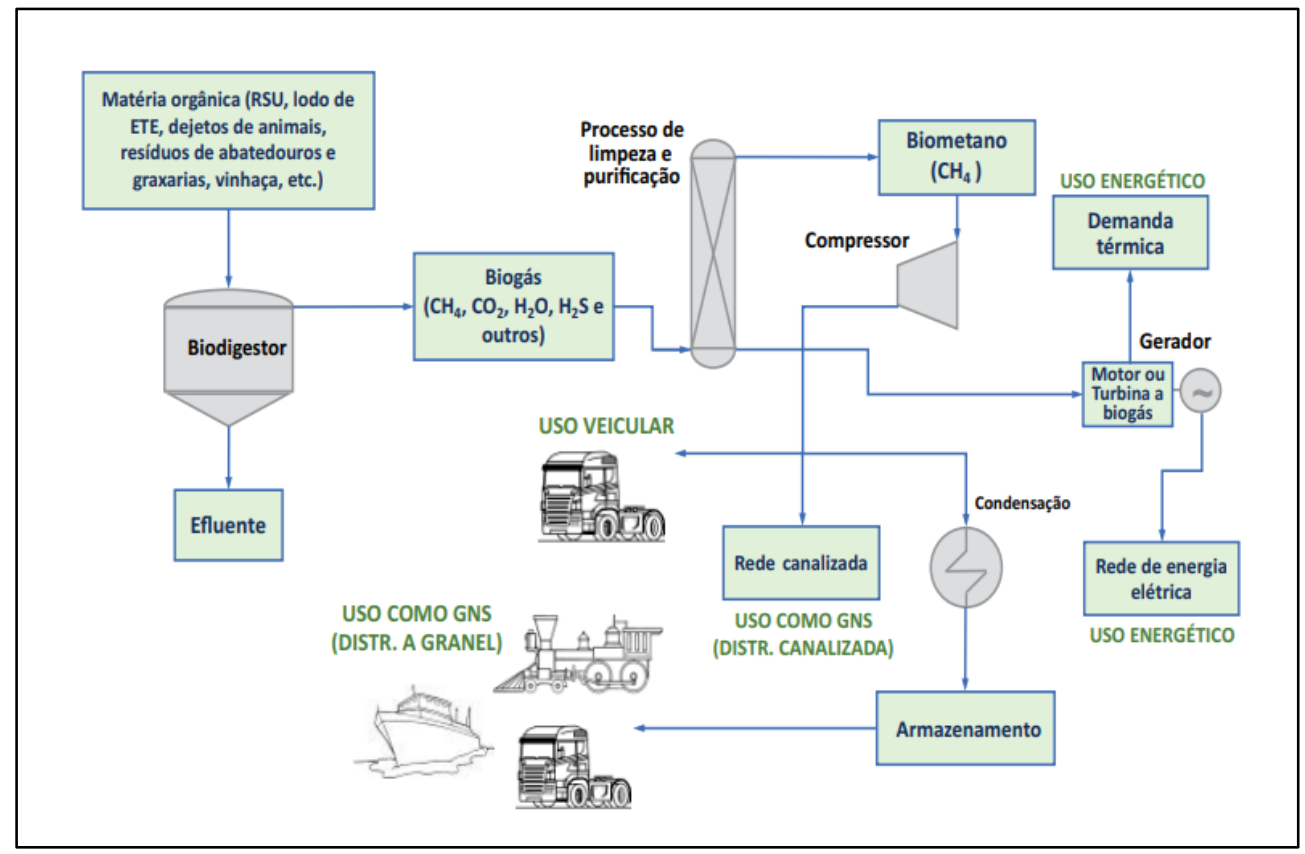

Figura3.9: Fluxograma simplificado da produção e consumos finais de biometano. Fonte: (COELHO, 2018).
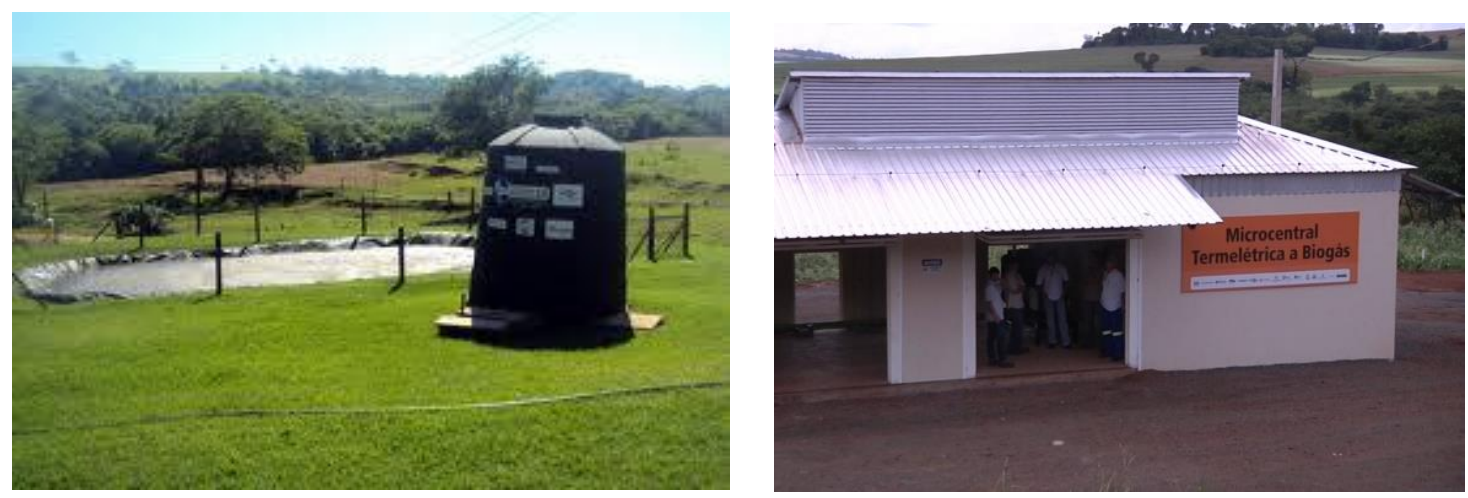

Figura 3.10: Biodigestor e Microcentral termoelétrica a biogás. Projeto Ajuricaba. Fonte: Plataforma de Boas Práticas para o Desenvolvimento Sustentável (2019). 
Outro exemplo de aproveitamento de resíduos, nesse caso esgoto, para geração de energia vem da Estação de Tratamento de Esgoto - ETE da Sabesp (Companhia de Saneamento Básico do Estado de São Paulo) em Franca. A parceria entre a empresa e o Instituto Fraunhofer da Alemanha teve investimento de $\mathrm{R} \$ 7,4$ milhões e dados técnicos indicam que no processamento de 500 1/s de esgoto, a ETE gera 2.500Nm3/dia de biogás, utilizado para abastecimento da frota da empresa que fez modificação de seus veículos para esse combustível, substituindo assim 1.500 1/dia de gasolina (SABESP, 2018).

A figura 3.11 mostra posto de abastecimento de biometano e parte da frota da Sabesp em Franca.

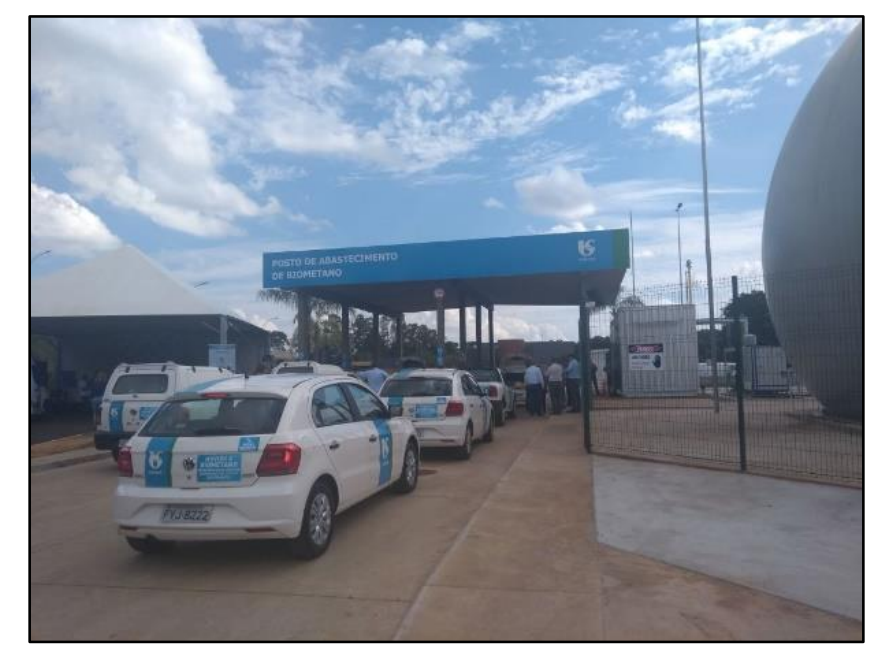

Figura 3.11: Posto de Abastecimento de Biometano. ETE Franca.

Fonte: Sabesp (2018).

\subsubsection{Gaseificação}

Trata-se de um processo termoquímico, que converte material carbonoso sólido ou semisólido num gás com características combustíveis, através de sua oxidação parcial a temperaturas intermediárias (oxigênio suprido em quantidades restringidas). Se o material carbonoso sólido for processado com vapor de água superaquecido incorporado ao agente gaseificante (oxigênio ou ar), é produzido o gás de síntese. A mistura gasosa produzida na gaseificação, também chamada de combustão estagiada, tem inúmeras aplicações práticas, como a combustão em motores alternativos de combustão interna, em turbinas para geração de energia mecânica e elétrica, para geração direta de calor ou como matéria-prima para obtenção de combustíveis líquidos e outros produtos químicos (LORA et al, 2008).

$\mathrm{Na}$ figura 3.12 é possível observar as rotas de gaseificação segundo o agente gaseificante. Os gaseificadores variam conforme tipo de leito (podem ser contracorrente, concorrentes, de 
fluxo cruzado, de leito fluidizado ou fixo), de acordo com agente gaseificante, pressão de trabalho, tipo de biomassa admitida e poder calorífico do gás resultante (INFIESTA, 2015; LORA et al, 2008).

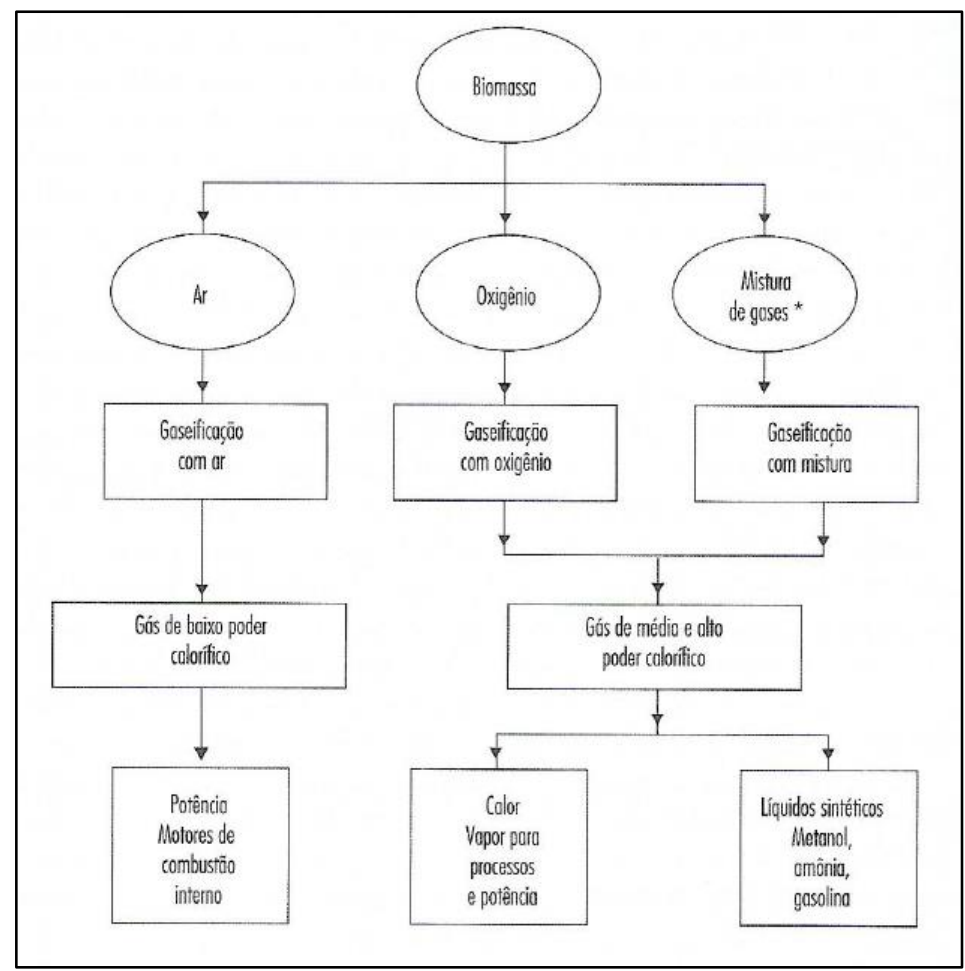

Figura 3.12: Rotas de gaseificação baseada no agente gaseificante.

* mistura de oxigênio e vapor dágua ou ar enriquecido com oxigênio e vapor dágua. Fonte: LORA et al (2008).

Esse gás, quando utilizado para geração de energia, pode ser aplicado em ciclos a ar ou ciclos combinados, com eficiência maior do que como aplicado como combustível em queima direta em ciclo Rankine. A gaseificação é um processo ainda não totalmente conhecido, mas consta de três etapas principais: secagem, pirólise e gaseificação propriamente dita. Embora conhecida desde as últimas décadas do século XVIII, as plantas instaladas pouco utilizam biomassa ou resíduo sólido urbano (RSU) (6 e 2\% respectivamente, em 2013) (INFIESTA, 2015; LORA et al, 2008).

No início dos anos 70, com as crises do petróleo, iniciaram-se esforços para desenvolvimento de unidades de pequena escala, movidas a biomassa e, nos anos 90, surge interesse para sistemas combinados de geração de energia elétrica e calor para processos industriais (LORA et al, 2008). Segundo Infiesta (2015), a utilização da gaseificação para geração de energia elétrica no mundo ocupava o terceiro lugar em 2012, com indícios de crescimento para os anos seguintes. 
A Usina Termoquímica de Geração de Energia (UTGE) de Boa Esperança, município no sul de Minas Gerais com aproximadamente 40 mil habitantes (IBGE, 2019) é um exemplo da viabilidade da utilização do RSU para geração de energia elétrica. A obra está quase finalizada, e é fruto de parceria entre a Prefeitura Municipal de Boa Esperança, Furnas Centrais Elétricas S/A e Carbogás Ltda (CARBOGAS, 2019).

Instalada numa área de $7.800 \mathrm{~m}^{2}$, tem capacidade de processamento de $60 \mathrm{t} / \mathrm{dia}$ de RSU (40 t produzidas pelo município e $20 \mathrm{t}$ desenterradas) e geração de $1 \mathrm{MW}$ de energia. Sendo a primeira cidade brasileira com geração de energia elétrica a partir do RSU, o investimento foi de R \$32 milhões com projeto de P\&D de Furnas e tecnologia 100\% nacional desenvolvida pela Carbogás. Além de gerar energia para abastecer cerca de $25 \%$ dos domicílios do município, com a utilização do lixo enterrado a prefeitura inicia a adequação à Política Nacional de Resíduos Sólidos (PNRS) (CARBOGAS, 2019).

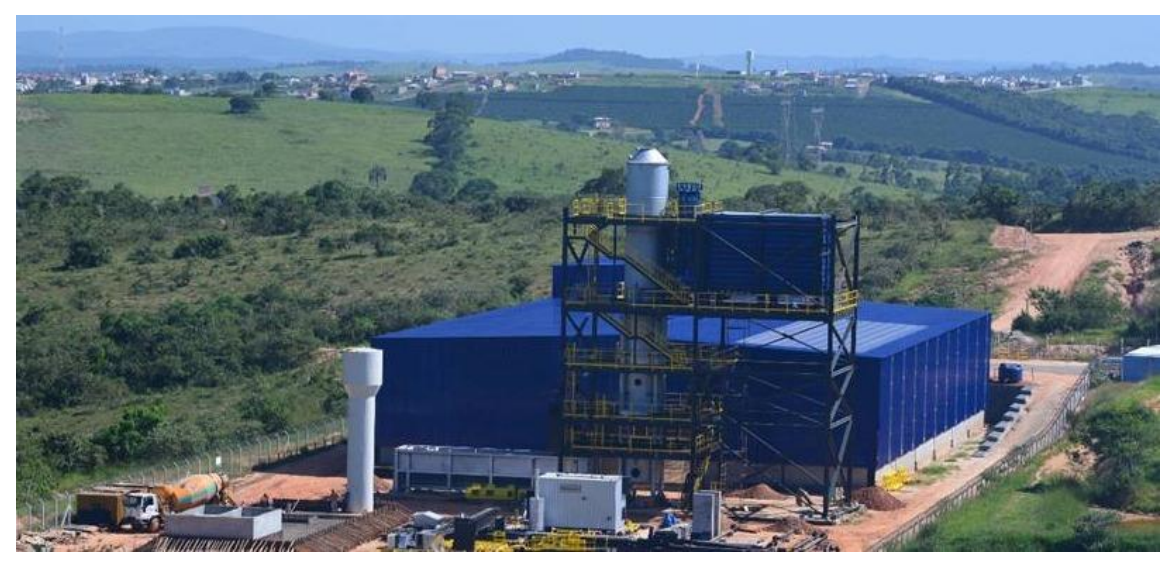

Figura 3.13: UTGE de Boa Esperança. Fonte: Carbogás (2019).

\subsection{CONCLUSÕES DO CAPÍTULO}

Embora sua conceituação seja subjetiva, a qualidade de vida se relaciona com bem-estar de forma holística, envolvendo as várias dimensões da vida humana. $\mathrm{O}$ acesso à energia é indispensável para possibilitar educação, saúde e renda, as três dimensões consideradas para determinação do IDHM, aos cidadãos.

A utilização da biomassa residual como fonte de energia pode fomentar o desenvolvimento sustentável, através das tecnologias aqui apresentadas, sendo a escolha feita caso a caso. Além da segurança energética, questões ambientais e socioeconômicas podem ser mais bem equacionadas com a adoção dessas soluções para aproveitamento energético da biomassa residual. 


\section{REALIDADES SEMELHANTES EM REGIÕES DESIGUAIS: LEVANTAMENTO DE DADOS EM ITAPICURU (BA) E RIBEIRÃO BRANCO (SP)}

Neste capítulo são apresentados os dados de levantamento de campo realizado nos dois municípios selecionados. O critério de seleção se baseou em dois conceitos:

- Seguindo a metodologia de seleção dos municípios do projeto BREA (GNESD, 2015), a ideia foi selecionar municípios de IDH inferior à média brasileira, que é 0,754 ;

- Além disso, a comparação entre o município de menor IDHM no estado de SP, que é o estado mais industrializado no país, com o município de menor IDHM num estado da região NE, no caso o estado da Bahia, buscou trazer a dureza das desigualdades regionais.

Assim sendo, foram selecionados os municípios de Ribeirão Branco e Itapicuru. Ribeirão Branco, no estado de São Paulo, com IDHM igual a 0,639, é o de menor índice no estado, com IDH médio de 0,783 e Itapicuru, na Bahia, com IDHM igual a 0,486, apresenta o menor IDH do estado, com média igual a 0,660 .

Foram então coletados dados de campo relativos aos municípios, bem como dados estatísticos secundários, para permitir o levantamento de potencial de aproveitamento energético dos resíduos de biomassa dos mesmos, contribuindo para o desenvolvimento sustentável de ambas as cidades selecionadas para o estudo.

\subsection{CARACTERIZAÇÃO DO TERRITÓRIO - ITAPICURU (BA)}

Nome de origem indígena Tupi-Guarani, Itapicuru ou "laje áspera" devido ao aspecto de rochas da região, foi habitada por Kariris, Payayás e Tupinambás. Portugueses chegaram através da distribuição de sesmarias pelo rei de Portugal. A freguesia criada no sec. XVII, foi elevada a vila em 1728 e designada município em 1911 (DANTAS, 2000).

Situado no nordeste baiano, distante $250 \mathrm{~km}$ da capital do Estado da Bahia - Salvador, possui clima semiárido e temperatura média de $24,2^{\circ} \mathrm{C}$. Município possui dois distritos conforme divisão territorial de 1963: Itapicuru e Sambaíba (GOOGLE MAPS, 2017; IBGE, 2019).

Itapicuru está classificado por número de habitantes em $959^{\circ}$ lugar no Brasil (5570 municípios) e em $82^{\circ}$ na Bahia (470 municípios), e apresenta os dados conforme tabela 4.1. 


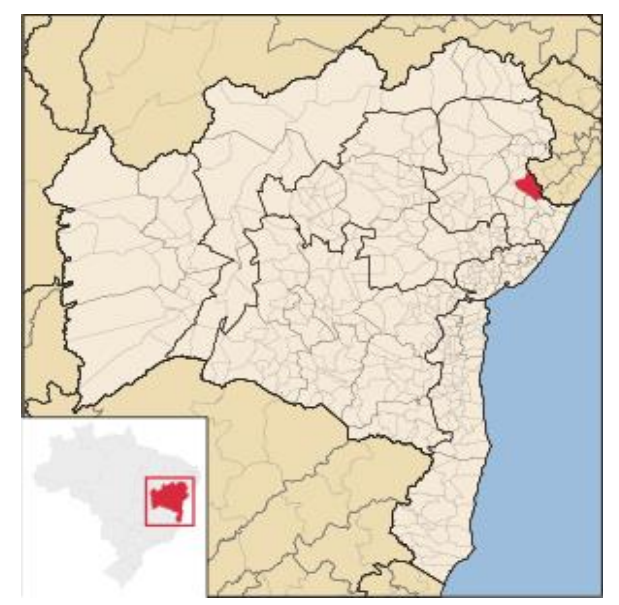

Figura 4.1: Localização do município de Itapicuru (BA).

Fonte: Google Maps (2017).

A figura 4.2 mostra que, em termos de gênero, a população é bem distribuída. Quanto ao local de moradia, há predomínio de habitação na zona rural, o que, juntamente com a densidade demográfica baixa, dá indicativos de dificuldades para ações voltadas à elevação da qualidade de vida da população.

Tabela 4.1: Dados populacionais de Itapicuru.

\begin{tabular}{|l|l|}
\hline População (censo 2010) & 32.261 hab. \\
\hline População estimada (2018) & 35.256 hab. \\
\hline Densidade demográfica (2010) & 20,35 hab/km2 \\
\hline Área (2018) & $1.556,747 \mathrm{~km} 2$ \\
\hline
\end{tabular}

Fonte: IBGE (2019).

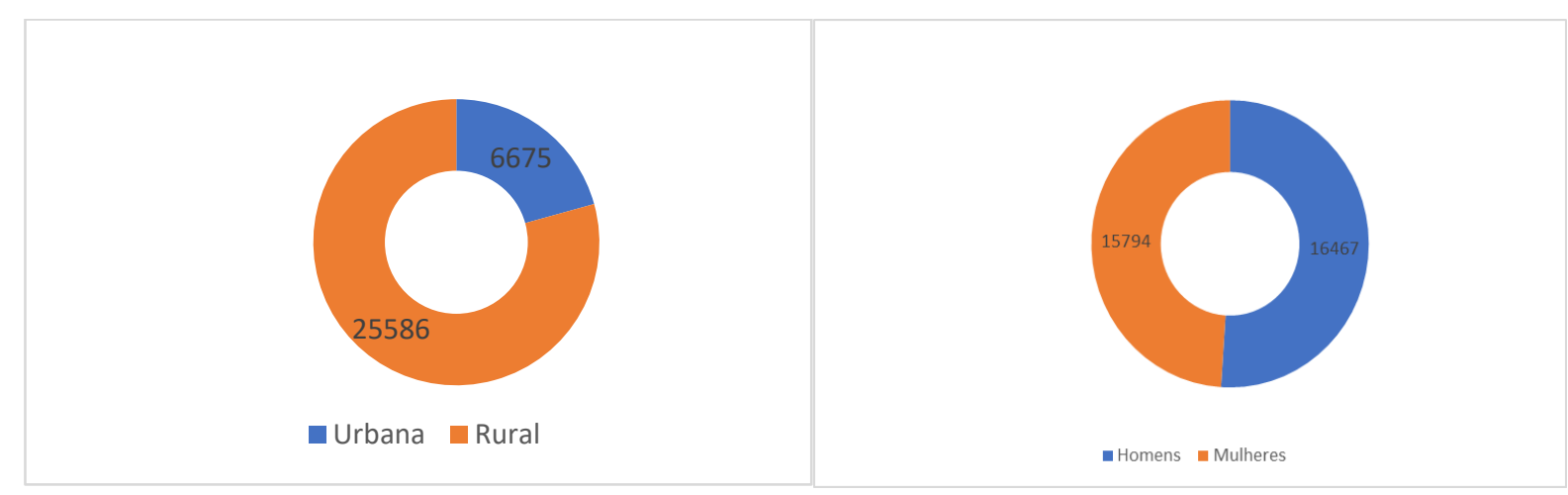

Figura 4.2: Distribuição populacional por local de moradia e gênero em Itapicuru. Censo 2010. Fonte: IBGE (2019). 
A população residente tem crescido, porém numa velocidade menor, e apresenta em sua pirâmide etária a mesma tendência de envelhecimento vista no Brasil (figura 4.3).

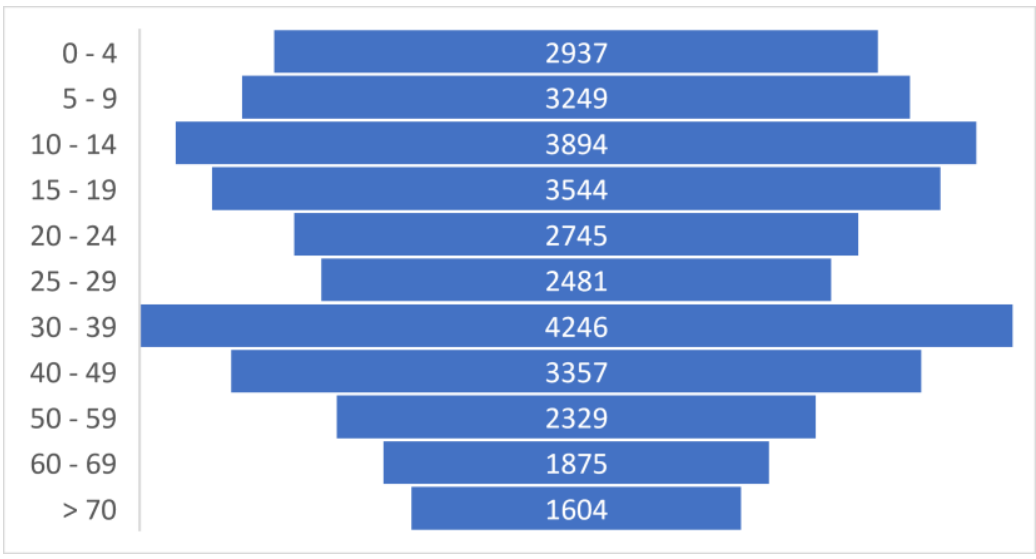

Figura 4.3: Distribuição da população residente por faixa etária. Censo 2010. Fonte: IBGE (2019).

Nas figuras 4.4 e 4.5 pode-se observar algumas imagens feitas durante visita de campo à cidade de Itapicuru, para melhor caracterização.
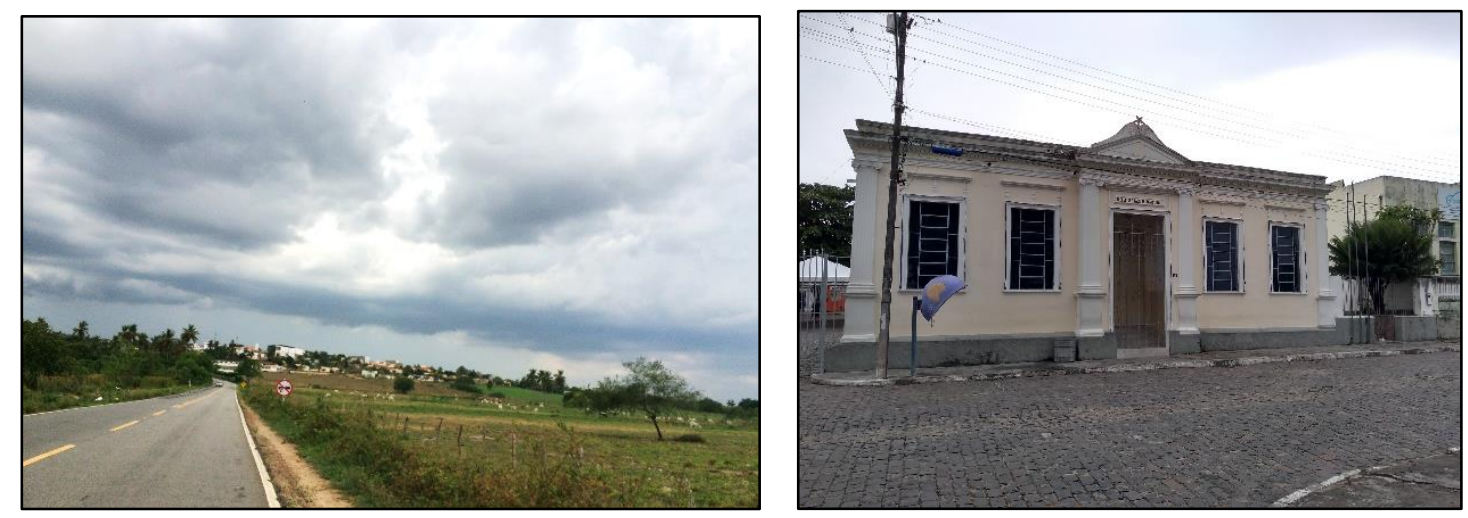

Figura 4.4: Itapicuru. Acesso à cidade e Prefeitura municipal à direita. Fonte: a autora em visita de campo (2018).
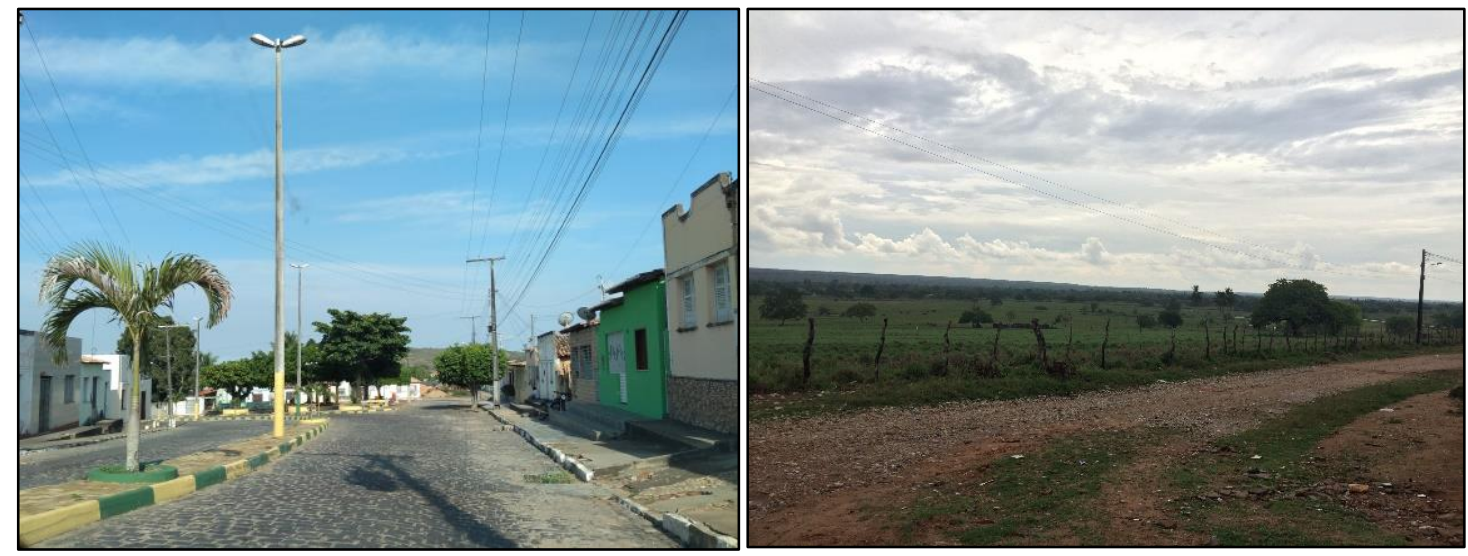

Figura 4.5: Itapicuru. Área urbana e rural. Fonte: a autora em visita de campo (2018). 


\section{2 CARACTERIZAÇÃO DO TERRITÓRIO - RIBEIRÃO BRANCO (SP)}

Através de doação em 1864, Francisco Caetano da Silva e sua esposa cederam terras para a construção de uma Capela em louvor ao Senhor Bom Jesus. Em torno dela surge um povoado que se eleva à categoria de vila em 1892 com nome do curso d'água próximo Ribeirão Branco. Designado município em 1906 que em 1934 foi extinto, voltando a ser distrito. Retoma a condição de município em 1944 (IBGE, 2019).

Situado na região do Alto do Paranapiacaba, distante $230 \mathrm{~km}$ em linha reta da grande metrópole que é o coração financeiro do país e capital do Estado - São Paulo, possui clima temperado com inverno menos seco e temperatura média de $18,0^{\circ} \mathrm{C}$. Município possui três distritos conforme divisão territorial de 1997: Ribeirão Branco, Campina de Fora e Itabôa (GOOGLE MAPS, 2017; IBGE, 2019).

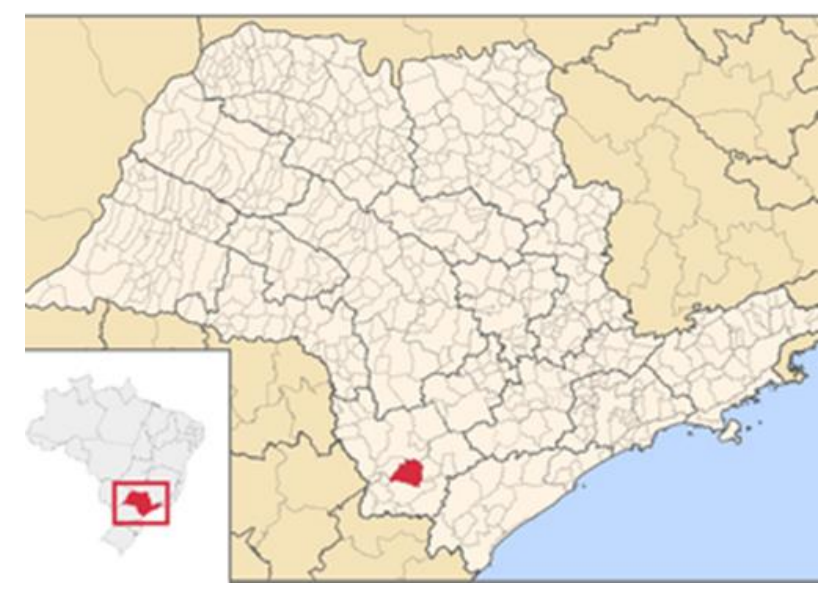

Figura 4.6: Localização do município de Ribeirão Branco (BA).

Fonte: Google Maps (2017).

Ribeirão Branco está classificado por número de habitantes em $1808^{\circ}$ lugar no Brasil (5570 municípios) e em $259^{\circ}$ em São Paulo (645 municípios), e apresenta os seguintes dados:

Tabela 4.2: Dados populacionais de Ribeirão Branco.

\begin{tabular}{|l|l|}
\hline População (censo 2010) & 18.269 hab. \\
\hline População estimada (2018) & 16.684 hab. \\
\hline Densidade demográfica (2010) & $26,19 \mathrm{hab} / \mathrm{km} 2$ \\
\hline Área (2018) & $697,500 \mathrm{~km} 2$ \\
\hline
\end{tabular}

Fonte: IBGE (2019). 
A figura 4.7 mostra que, em termos de gênero, a população é bem distribuída. Quanto ao local de moradia, há discreto predomínio de habitação na zona rural, denotando característica econômica do município voltado ao agronegócio.

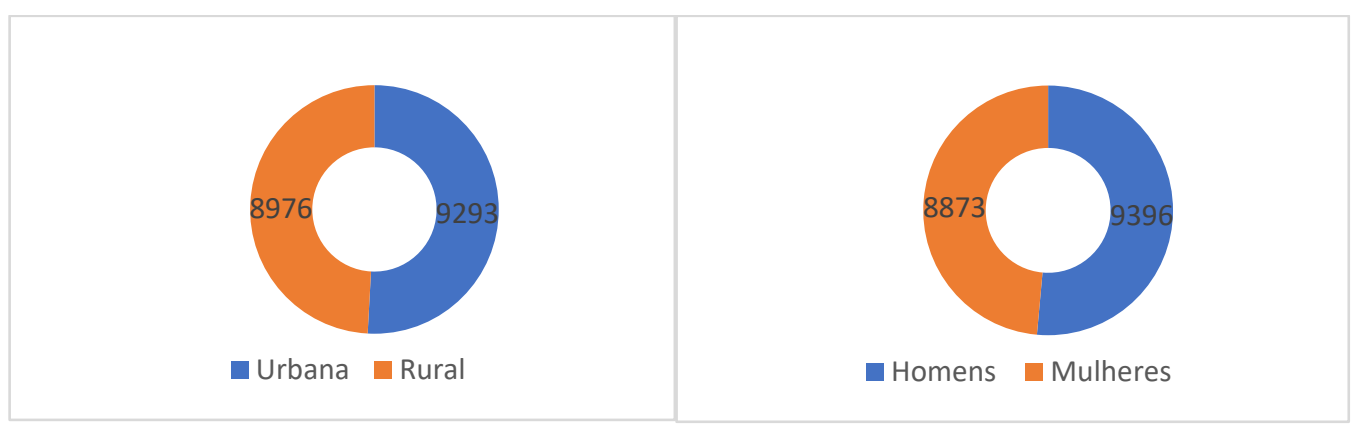

Figura 4.7: Distribuição populacional por local de moradia e gênero em Ribeirão Branco. 2010.

Fonte: IBGE (2019).

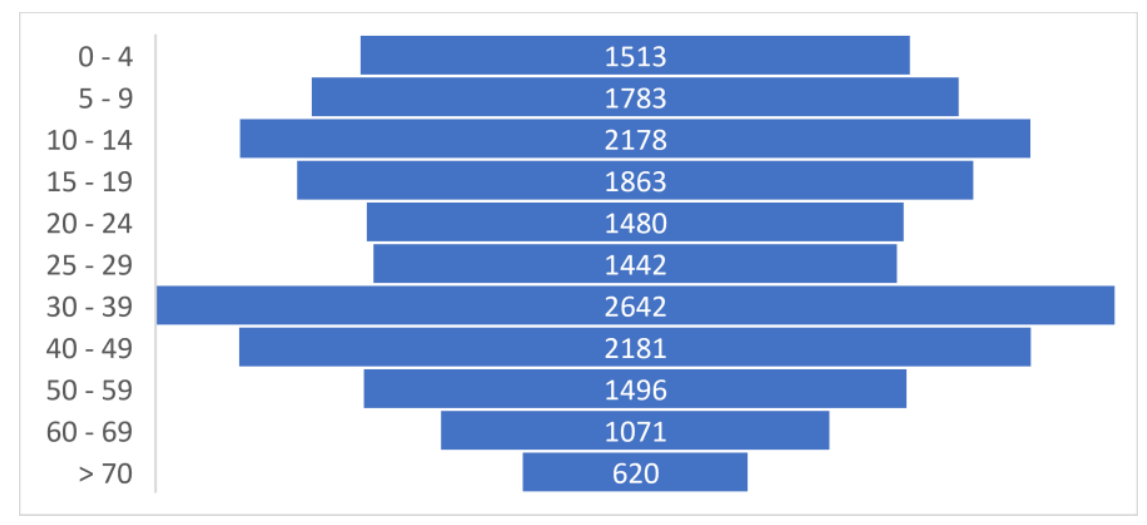

Figura 4.8: Distribuição da população residente por faixa etária. Censo 2010.

Fonte: IBGE (2019).

A população residente tem diminuído e apresenta em sua pirâmide etária a mesma tendência de envelhecimento vista no Brasil (figura 4.8).

Nas figuras 4.9 e 4.10 pode-se observar algumas imagens feitas durante visita de campo à cidade de Ribeirão Branco, para melhor caracterização.
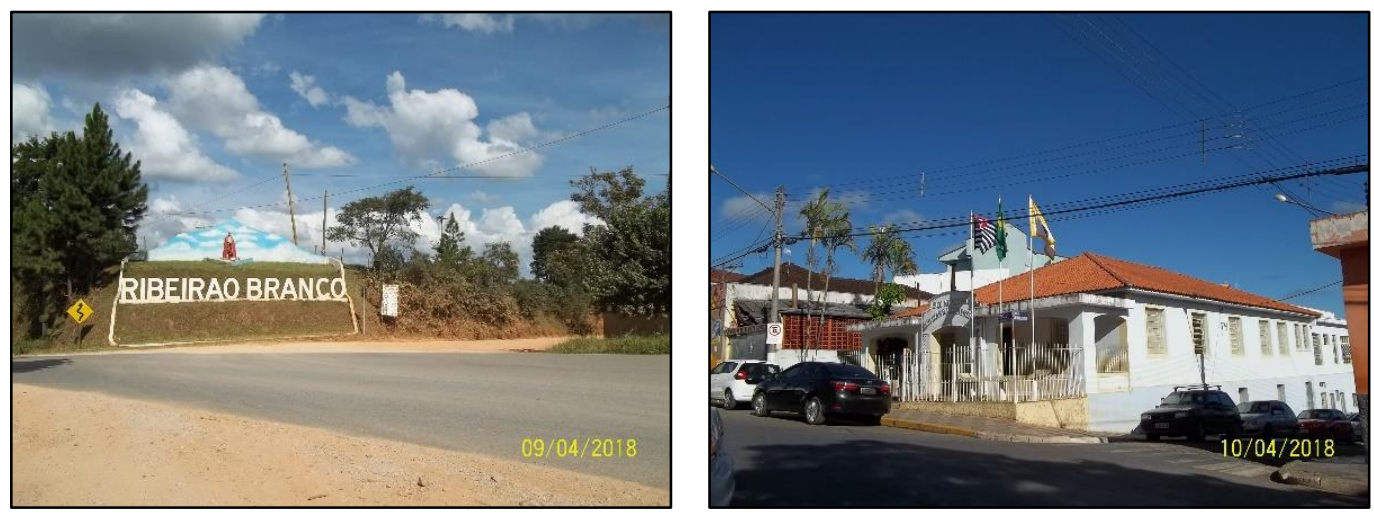

Figura 4.9: Ribeirão Branco. Acesso à cidade e Prefeitura municipal à direita. Fonte: a autora em visita de campo (2018). 

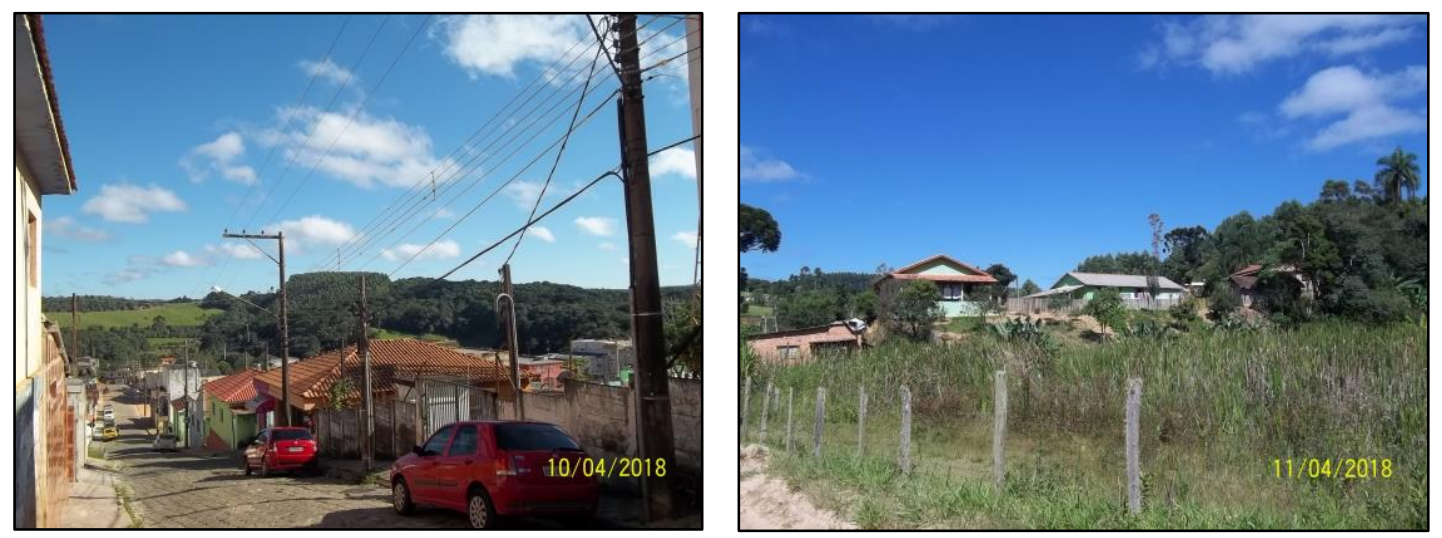

Figura 4.10: Ribeirão Branco. Área urbana e rural.

Fonte: a autora em visita de campo (2018).

\section{3 ÍNDICE DE DESENVOLVIMENTO HUMANO MUNICIPAL - IDHM}

O IDHM é um índice que utiliza a metodologia do IDM com adequações para características regionais. Calculado para os municípios brasileiros desde 1998, os últimos dados divulgados para os municípios estudados são de 2010. A figura 4.11, intitulada árvore comparativa do IDHM, mostra ao fundo a projeção do IDHM ideal, que seria 1. À frente veemse os valores para o IDHM real (caule da árvore) e as suas três dimensões: educação, renda e longevidade.

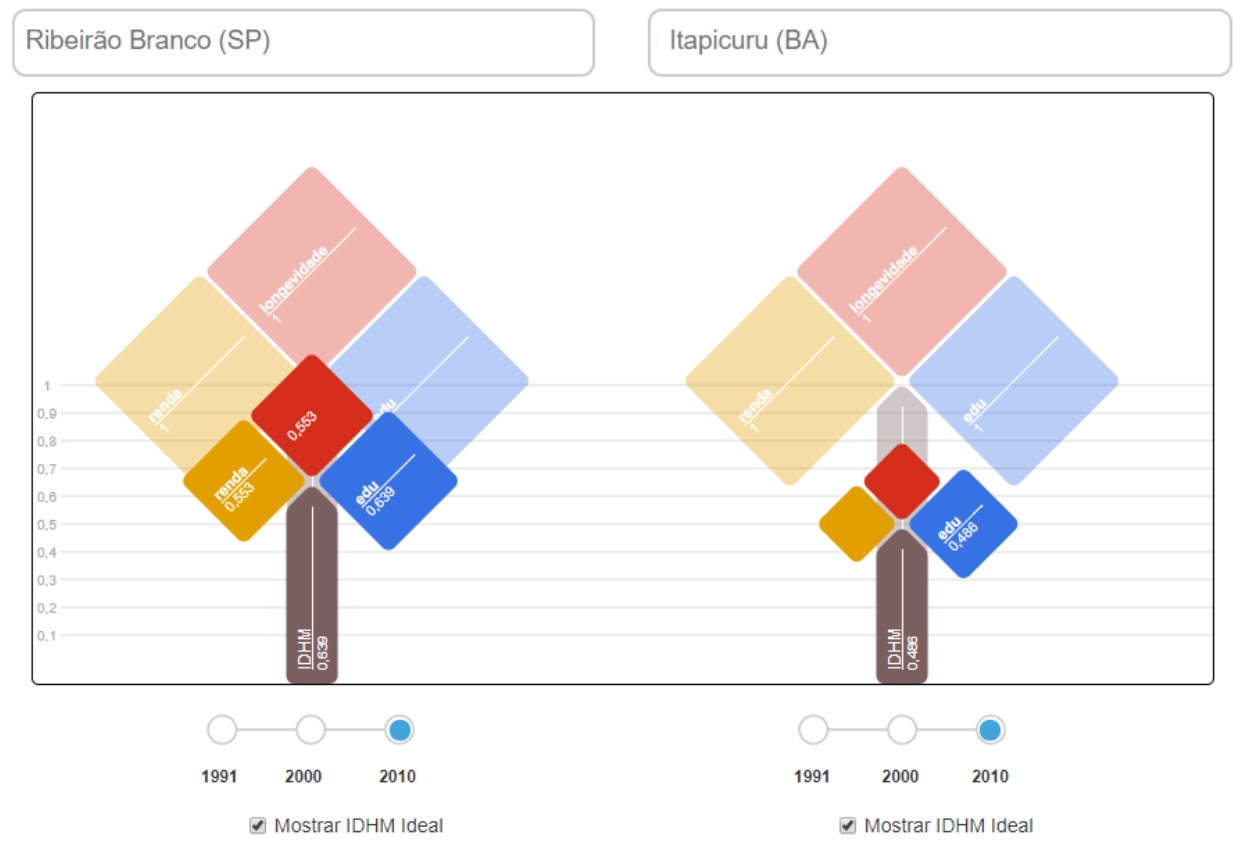

Figura 4.11: Árvore comparativa do IDHM.

Fonte: PNUD (2019). 
Percebe-se grande diferença entre as duas cidades. Mesmo sendo o pior índice do estado de São Paulo, Ribeirão Branco ainda assim está numa situação menos crítica que Itapicuru. Isso demonstra a desigualdade que existe entre as regiões do país.

O IDHM é formado por indicadores em três dimensões e, de acordo com dados da última coleta de dados, vemos surgir as desigualdades entre as cidades deste estudo (tabela 4.3).

Tabela 4.3: IDHM dos municípios desmembrado em dimensões.

\begin{tabular}{|l|c|c|}
\hline Município & Itapicuru & Ribeirão Branco \\
\hline Educação & 0,319 & 0,553 \\
\hline Longevidade & 0,711 & 0,797 \\
\hline Renda & 0,505 & 0,592 \\
\hline
\end{tabular}

Fonte: PNUD (2019).

Dentre os 5.565 municípios pesquisados em 2010, Itapicuru tinha o pior dado do estado da Bahia e estava em 5.548 ${ }^{\circ}$ no Brasil, situando-se na faixa de IDHM muito baixo (entre 0 e 0,499) com 0,486. Ribeirão Branco, por outro lado, embora com o pior dado do Estado de São Paulo, ocupava o $3312^{\circ}$ no país, apresentando IDHM classificado como médio (entre 0,600 e 0,699) com valor 0,639 (PNUD, 2019).

Analisando a evolução histórica (fig. 4.12), nota-se que, desde 1991, houve melhora nas três dimensões, resultando num IDHM crescente. Isso foi uma tendência nacional, que também se percebeu nos estados (BA e SP) e municípios de estudo. Mas a elevação da qualidade de vida se deu de forma desigual, tanto entre os municípios como nos diferentes indicadores que compõe o índice.

No município de Itapicuru, a taxa de crescimento do IDHM no período compreendido entre 1991 e 2010 foi de 145,45\%, enquanto em Ribeirão Branco a elevação do índice no mesmo período foi de $108,82 \%$ e, no Brasil, 47\%. A dimensão que teve maior elevação nos dois municípios foi educação, seguidos por longevidade e renda.

Embora tenha havido crescimento do IDHM, a figura 4.13 mostra que, na dimensão longevidade os valores comparativos entre os municípios, seus respectivos estados e a federação estão próximos. A dimensão renda apresenta grande defasagem, mas é na educação que o contraste é mais significativo, embora esta dimensão seja uma dificuldade nacional. 
IDHM

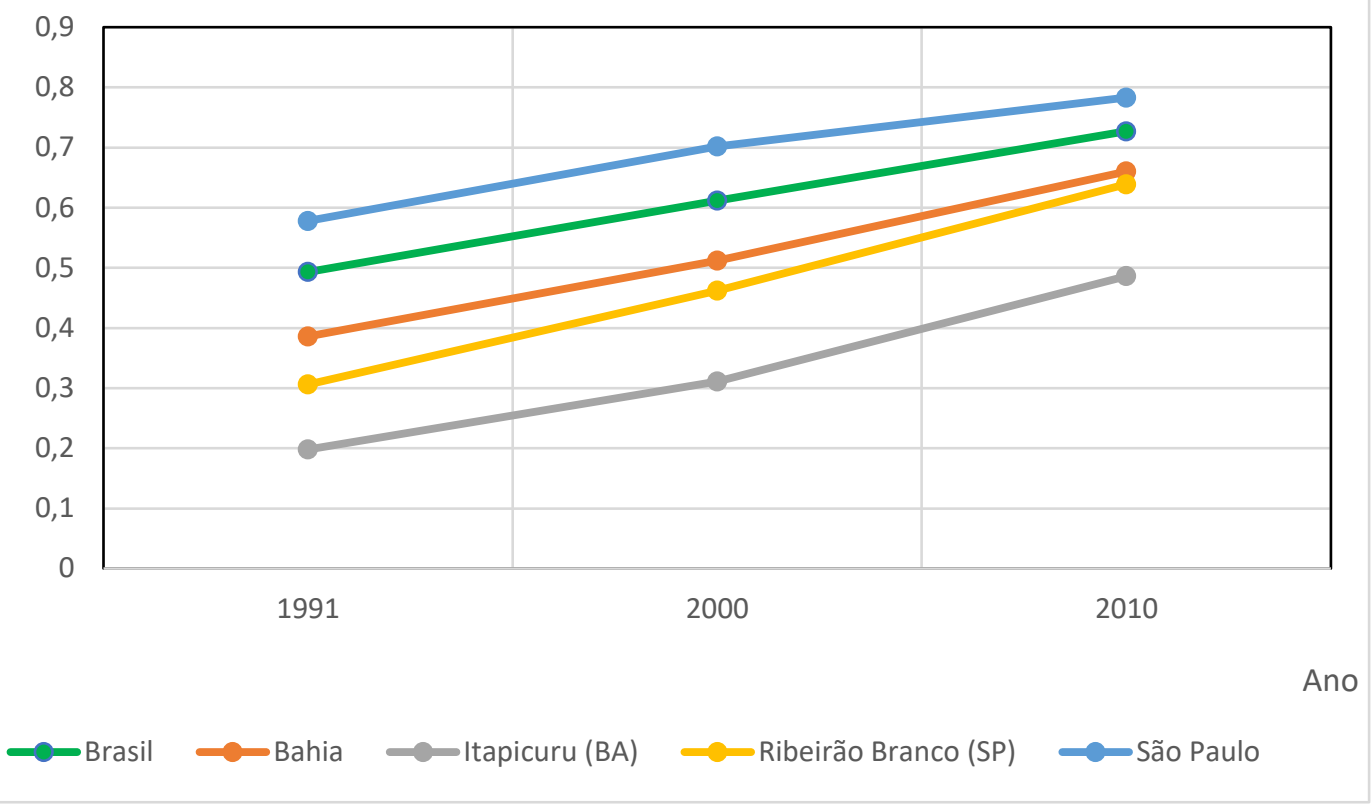

Figura 4.12: Evolução do IDHM.

Fonte: preparado pela autora baseado em PNUD (2019).

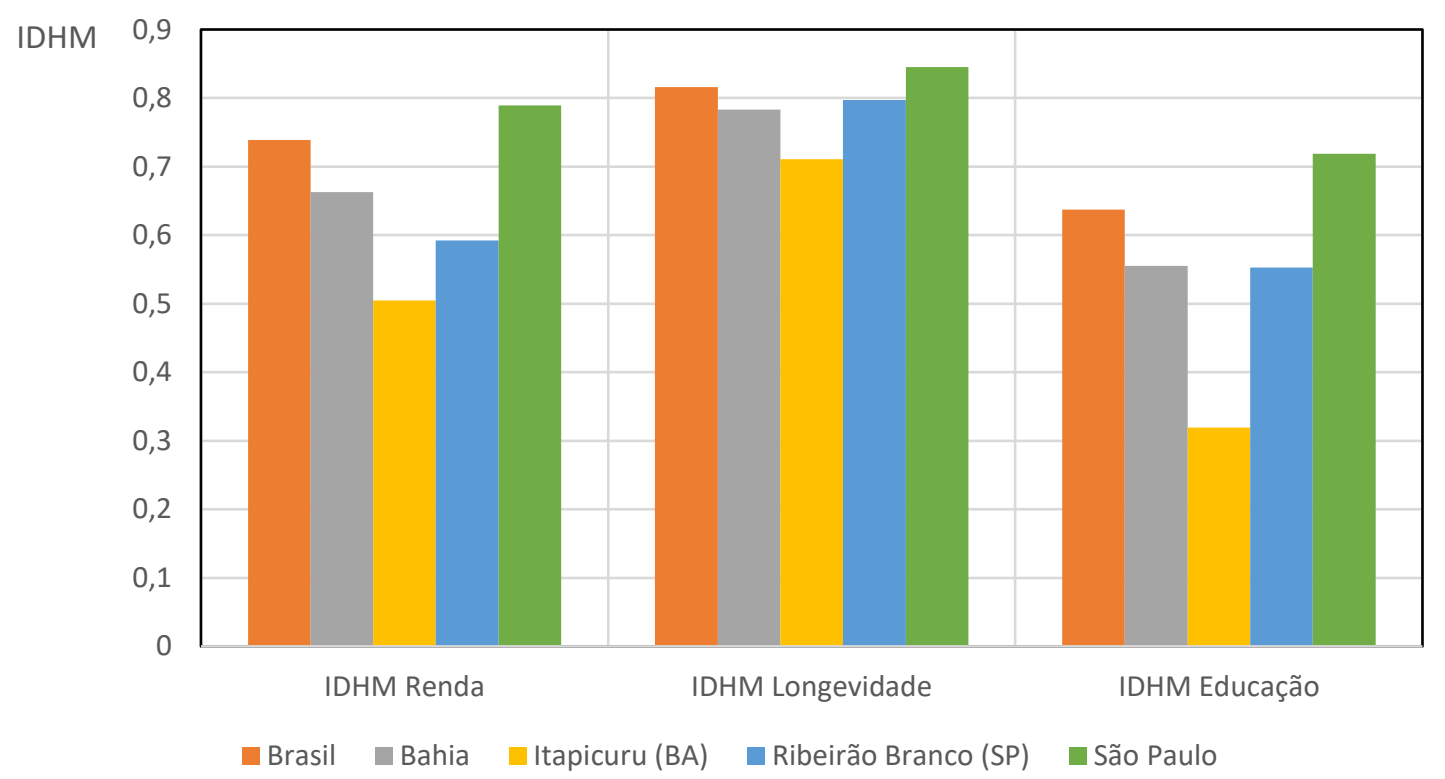

Figura 4.13: Comparativo de IDHM (2010) por dimensão.

Fonte: Preparado pela autora baseado em PNUD (2019).

\subsection{EDUCAÇÃO NOS MUNICÍPIOS}

Este indicador possui grande inércia, uma vez que as pessoas mais velhas têm peso importante, e as iniciativas positivas em educação vão mostrar resultado apenas com o passar dos anos. É na educação onde se percebe a maior disparidade entre os municípios. Enquanto 
quase metade da população em Itapicuru maior de 25 anos é analfabeta, esse número fica em torno de $16 \%$ em Ribeirão Branco e $12 \%$ no país.

Outros indicadores que compõe o índice na dimensão Educação mostram de forma mais abrangente as dificuldades encontradas pela população. A taxa de escolarização entre crianças de 6 a 14 anos de idade é 95,6\% em Itapicuru e 97,5\% em Ribeirão Branco (dados de 2010) porém em comparativo entre 2007 a 2017, as matrículas em ambas cidades apresentam números decrescentes (IBGE, 2019).

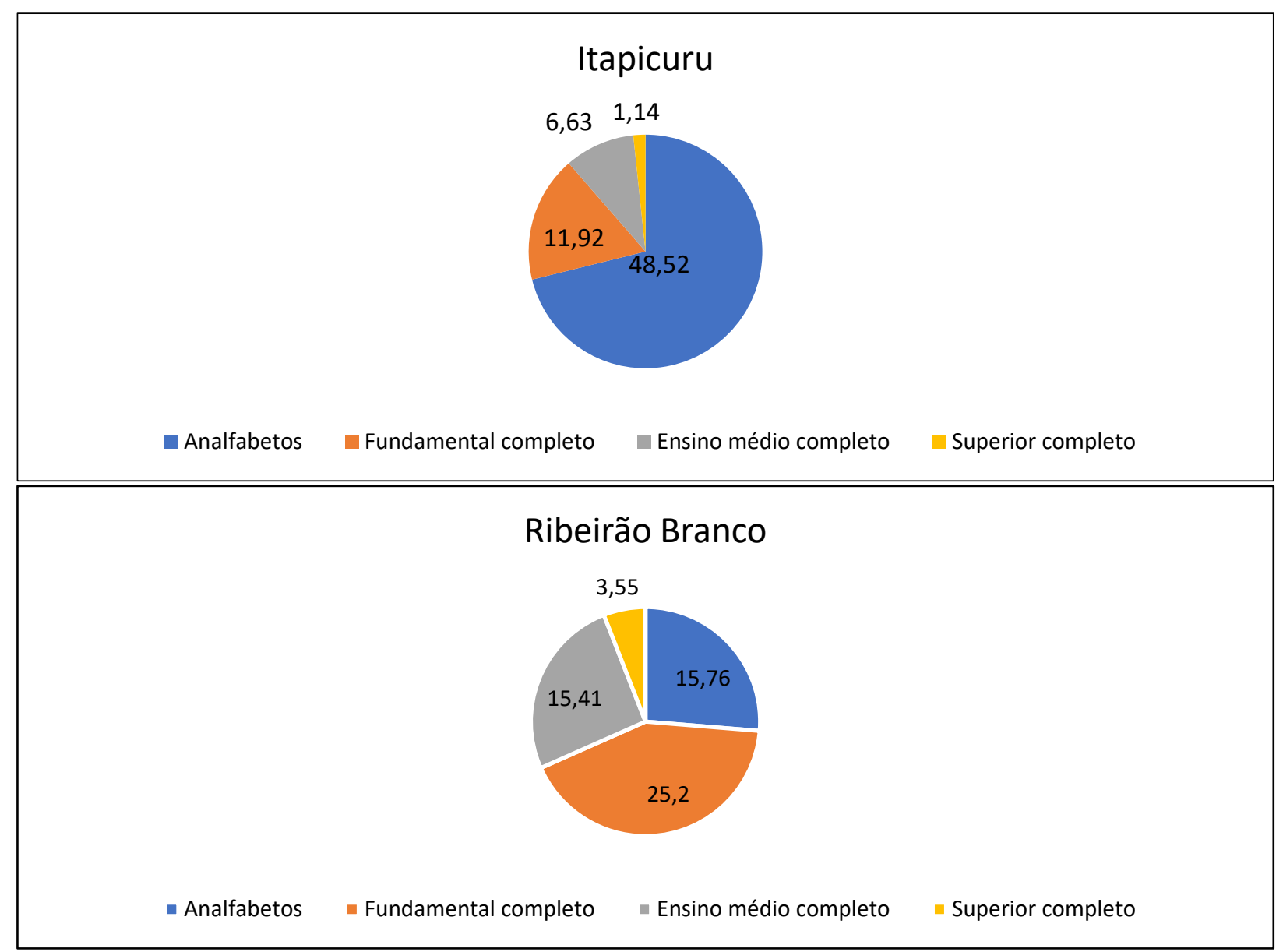

Fig. 4.14: Percentual de habitantes com 25 anos ou mais conforme escolaridade nos municípios (2010).

Fonte: Preparado pela autora baseado em PNUD (2019).

Com relação à qualidade do ensino, o IDEB - índice de Desenvolvimento da Educação Básica do Ministério da Educação, que tem valor entre 0 e 10 e avalia a melhoria do ensino público. O Brasil está bem abaixo das metas, embora tenha sentido discreta melhoria em algumas etapas. Na tabela 4.4, pode-se observar os dados, sendo que a única nota de não ficou abaixo das metas foi no $4 / 5^{\circ}$ ano em Ribeirão Branco, denotando que a cidade tem feito esforço para melhorara educação de base (INEP, 2019). 
Tabela 4.4: IDEB dos municípios (2017).

\begin{tabular}{|l|c|c|}
\hline Município & Itapicuru & Ribeirão Branco \\
\hline $4 / 5^{\circ}$ ano & 4,1 & $6,9^{*}$ \\
\hline $8 / 9^{\circ}$ ano & 2,3 & 5,2 \\
\hline $3^{\text {a }}$ série ensino médio & 3,2 & 4,3 \\
\hline
\end{tabular}

Fonte: INEP (2019). * indica que atingiu meta.

Conforme dados de 2017, em Itapicuru existem 58 estabelecimentos de ensino fundamental (1 privado apenas) e 3 de ensino médio. Ribeirão Branco conta com 16 escolas de ensino fundamental e 6 de ensino médio, todos públicos (IBGE, 2019). Em ambas cidades não há faculdades ou universidades. Os estudantes que desejam seguir num curso superior devem se deslocar para cidades maiores da região (entre 40 e $160 \mathrm{~km}$ ) ou cursar alguma opção de ensino à distância.

Educação continua sendo o maior desafio do país e, se difícil nas grandes cidades, as barreiras são maiores em municípios com baixo IDHM onde as perspectivas são menos propícias para investimentos e ações para reverter o quadro. A figura 4.15 mostra imagens de algumas instituições de ensino nos municípios do estudo.
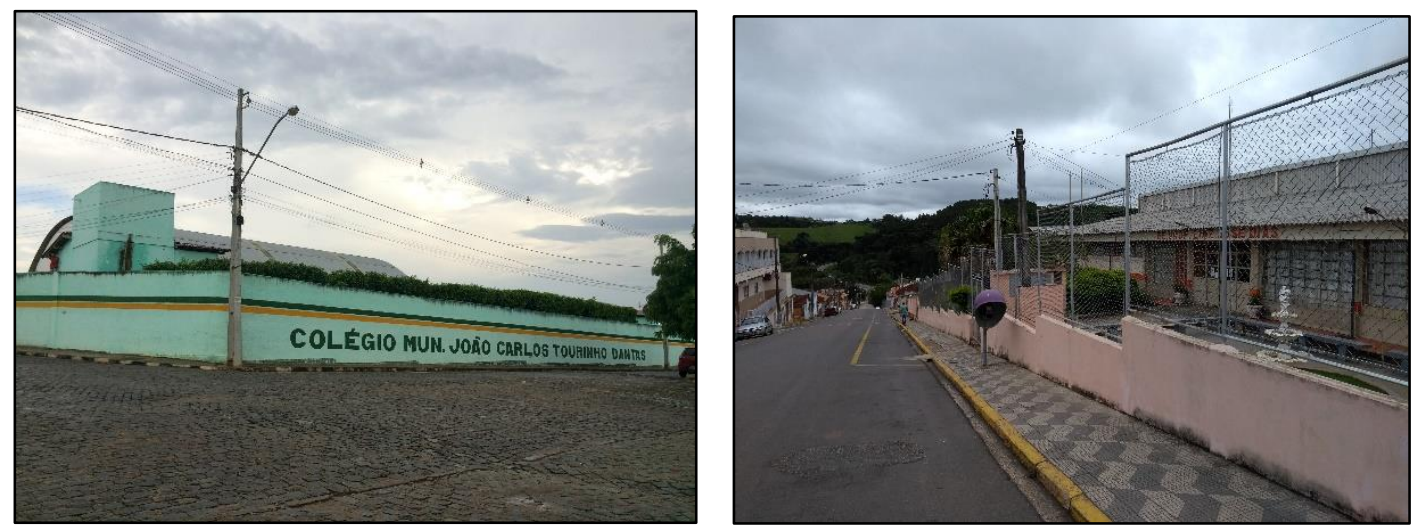

Figura 4.15: Instituições de ensino. Itapicuru (esq.) e Ribeirão Branco (dir.) Fonte: a autora em visita de campo (2018).

\subsection{LONGEVIDADE NOS MUNICÍPIOS}

A dimensão saúde é avaliada sob o ponto de vista da longevidade. Embora os dados tenham melhorado significativamente desde 1991, ainda se vê desigualdade. A mortalidade 
infantil caminha para atingir uma das metas dos Objetivos de Desenvolvimento do Milênio (ODM), que preconiza número abaixo de 17,9 óbitos por mil nascidos vivos até 2015.

Dados mais recentes mostram que, em Itapicuru, a mortalidade infantil em 2014 estava em 19,66 óbitos/mil nascidos vivos (número expressivamente melhor que em 2010), e as internações por diarreia, grande causa de óbitos em crianças, estava em 1,1 por mil habitantes (2016) (IBGE, 2019).

Os números referentes à saúde, em 2009, trazem que existem 9 estabelecimentos de saúde em Itapicuru, sendo 1 particular e 8 públicos que fazem atendimento pelo Sistema Único de Saúde - SUS. Apenas 1 deles faz atendimento de emergência e não há leitos disponíveis para internação na cidade (IBGE, 2019).

Tabela 4.5: Comparativo de dados (2010) sobre longevidade nos municípios estudados.

\begin{tabular}{|l|c|c|}
\hline & Itapicuru & Ribeirão Branco \\
\hline $\begin{array}{l}\text { Esperança de vida ao nascer - anos } \\
\text { Mortalidade infantil (óbitos por mil nascidos }\end{array}$ & 67,6 & 72,8 \\
\hline $\begin{array}{l}\text { vivos) } \\
\text { Mortalidade até 5 anos de idade (óbitos por mil } \\
\text { nascidos vivos) }\end{array}$ & 38,0 & 18,3 \\
\hline \begin{tabular}{l} 
Taxa de fecundidade total \\
\hline
\end{tabular} & 2,6 & 21,2 \\
\hline
\end{tabular}

Fonte: PNUD (2019).

Ribeirão Branco apresenta mortalidade infantil em 9,93 óbitos/mil (2014) nascidos vivos (já dentro da meta do ODM) e 0,5 internação por diarreia a cada mil habitantes (2016). Na cidade há 6 estabelecimentos de saúde públicos, que fazem atendimento pelo SUS, e 1 privado. Desses 7 estabelecimentos, 1 faz atendimento de emergência e existem 38 leitos disponíveis para internação via SUS (IBGE, 2019).

O retrato da saúde nos municípios fica mais completo ao mencionar os equipamentos para exames em 2009: em Ribeirão Branco havia 1 equipamento de Raio-X e em ambas se encontrava 1 ecocardiógrafo cada. Nenhuma das duas cidades apresentava eletroencefalógrafo, mamógrafo, equipamentos para tomografia, ressonância magnética, ultrassonografia e 
hemodiálise (IBGE, 2019). No caso de necessidade de quaisquer um desses equipamentos para diagnóstico ou tratamento, os pacientes devem se deslocar, no mínimo, 40 km.

Mesmo ainda distante da situação ideal, o Ministério da Saúde (MS) tem lançado programas visando aumentar a longevidade e qualidade de vida, como o Plano de Enfrentamento das Doenças Crônicas não Transmissíveis (DCNT) em 2011, ações de Vigilância em Saúde como a pesquisa Vigilância de Fatores de Risco e Proteção para Doenças Crônicas por Inquérito Telefônico (Vigitel), realizada anualmente desde 2006, o Programa da Farmácia Popular (2011) entre outros, promovendo a saúde e prevenindo doenças (BRASIL MS, 2012). Com isso, entre as três dimensões, a longevidade é onde se vê a menor desigualdade entre os municípios e os dados do Brasil.

A figura 4.16 mostra imagens de unidades de saúde nos municípios estudados.

Outros dados importantes para saúde como acesso à água potável, esgotamento sanitário e coleta de lixo serão tratados em secção à parte, devido sua extrema importância na qualidade de vida e pelo aproveitamento energético a ser considerado.
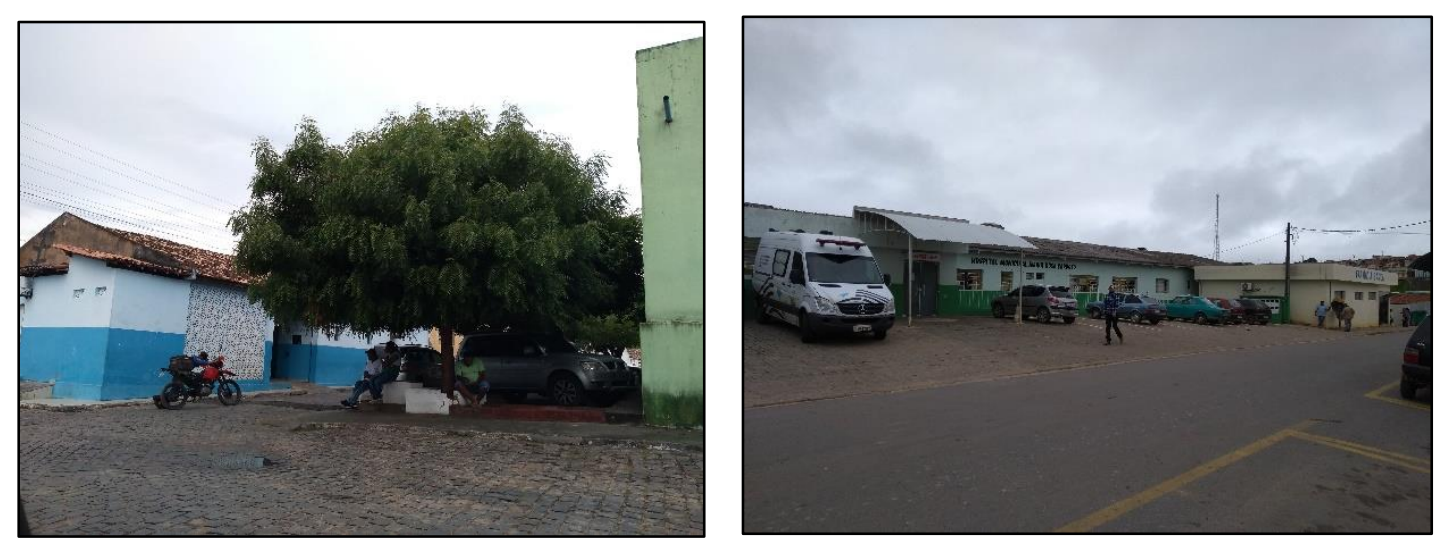

Figura 4.16: Unidades de saúde. Itapicuru (esq.) e Ribeirão Branco (dir.) Fonte: a autora em visita de campo (2018).

\subsection{RENDA NOS MUNICÍPIOS}

A receita dos municípios, dados sobre trabalho, renda e atividade econômica trazem um panorama das possibilidades e dificuldades encontradas.

O Produto Interno Bruto (PIB) municipal per capita, ou seja, o somatório das receitas de bens e serviços produzidos no município dividido pelos habitantes do município, é um primeiro indicativo da situação. Segundo dados de 2016, Itapicuru apresentava R \$ 10.220,81 e Ribeirão Branco R\$23.377,90 de PIB per capita (IBGE, 2019). Esse indicador, porém, é apenas uma 
síntese macroeconômica, que, embora ajude a ter uma primeira visão da situação da cidade, não expressa a real distribuição de renda, qualidade de vida, saúde e educação. Quanto maior a desigualdade, e este é o caso dos municípios do estudo, mais distante da real situação do padrão de vida das populações é a informação mostrada por esse indicador.

A avaliação da participação percentual das atividades no PIB municipal mostra quais áreas geram maior faturamento nas cidades. A figura 4.17 mostra que em Itapicuru, a atividade agropecuária participa com mais de $40 \%$ no PIB municipal, reforçando a vocação rural do município. Em Ribeirão Branco, a situação mostra que o setor de serviços, seguido das atividades públicas, são a maior contribuição no PIB da cidade. Esse fato enfatiza a dificuldade de maiores oportunidades de renda na região.

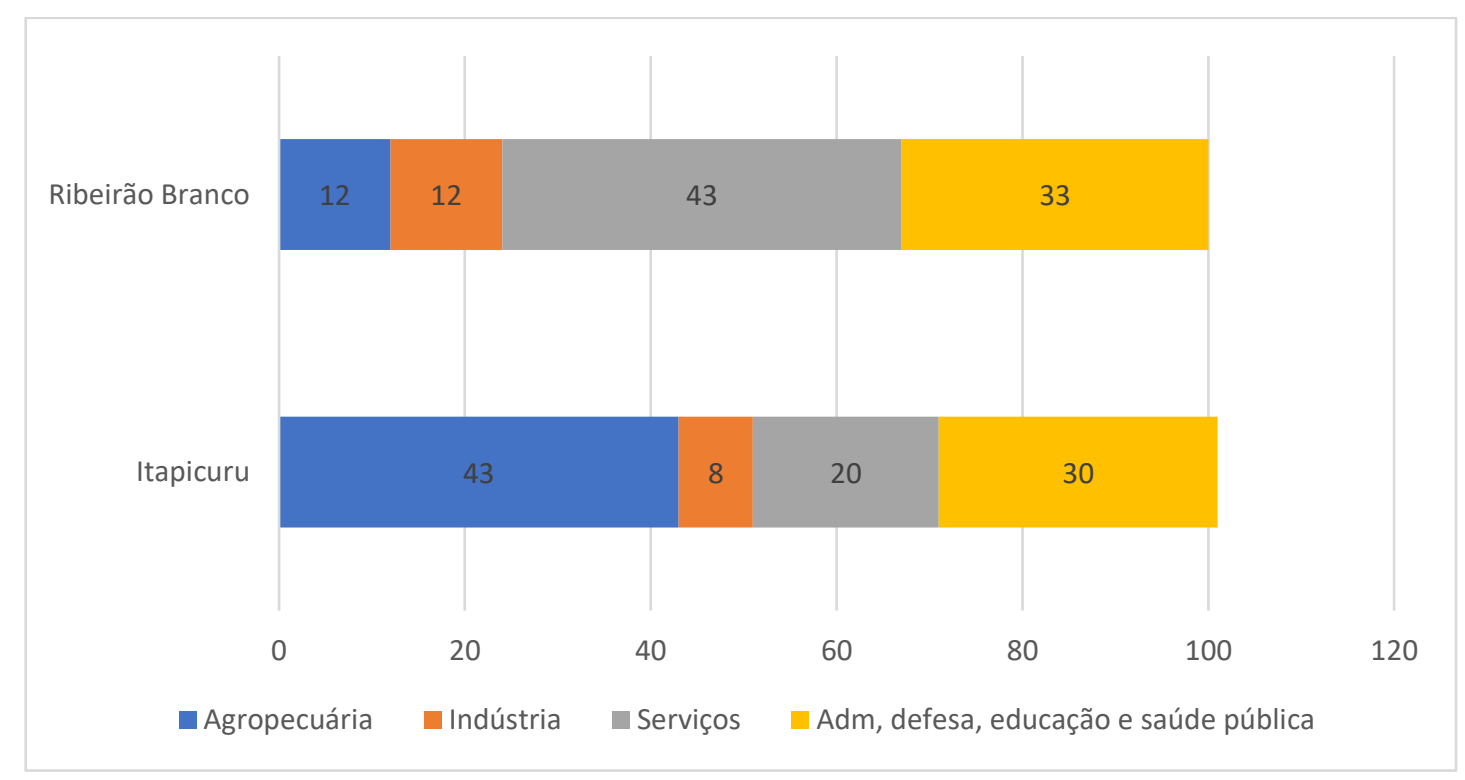

Figura 4.17: Percentual de participação no PIB municipal por atividade (2016).

Fonte: Preparado pela autora baseado em IBGE (2019).

Outros dados, obtidos a partir do CNAE - Código Nacional de Atividade Econômica definidos pelo IBGE, dá um panorama de empresas por setor em cada um dos municípios estudados. Ribeirão Branco tem um número superior a Itapicuru de empresas, sendo a maioria no agronegócio. Se o PIB do setor não é tão representativo, indica que são em grande número, mas pequenas propriedades em faturamento na cidade paulista. Já na cidade baiana, poucas empresas do setor agro garantem quase metade do PIB da cidade, indicando serem fazendas com grande faturamento.

Nos demais setores, a distribuição de empresas demonstra equilíbrio com PIB do setor. A tabela 4.6 mostra a distribuição das empresas nos municípios, por atividade, segundo o CNAE. 
Itapicuru conta com 1 agência de instituição financeira e Ribeirão Branco 2, indicando que a taxa de circulação monetária na cidade é baixa (figura 4.18).
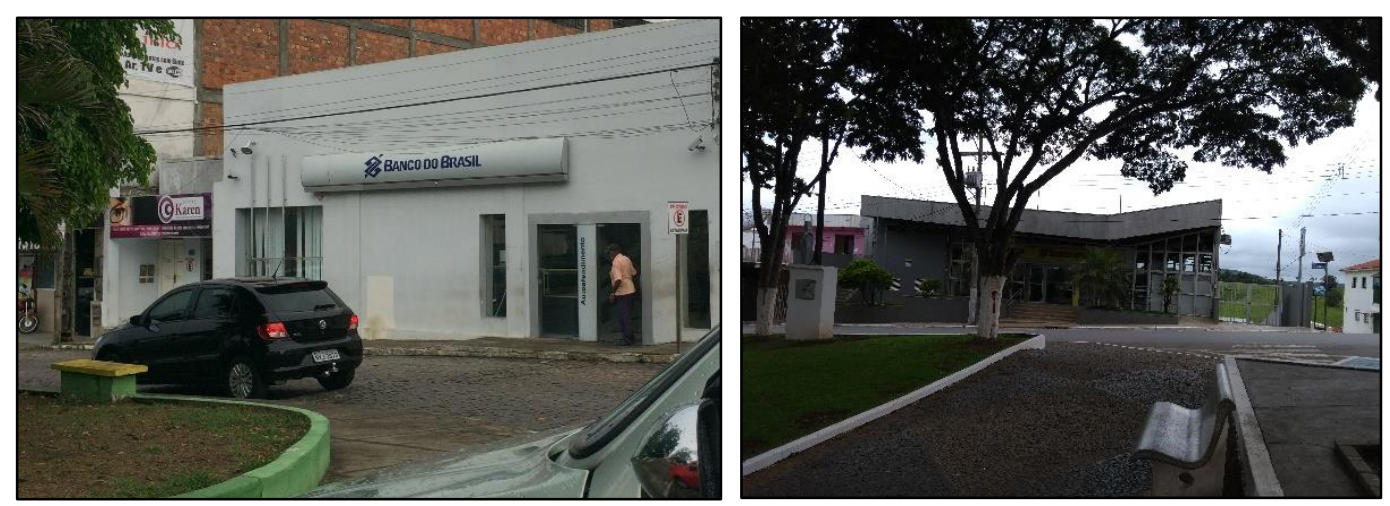

Figura 4.18: Agências bancárias. Itapicuru (esq.) e Ribeirão Branco (dir.)

Fonte: a autora em visita de campo (2018).

A distribuição da população com 18 anos ou mais, de acordo com sua condição de trabalho, é muito similar nos municípios como se pode ver na figura 4.19.

Dentre as pessoas com 18 anos ou mais, que estavam ocupadas nos municípios em 2010, a distribuição de acordo com o setor de atuação se encontra na figura 4.20. Percebe-se o maior número de pessoas envolvidas no setor agropecuário, indicando vocação para o agronegócio nas duas cidades, seguida com certa folga pelo setor de serviços.

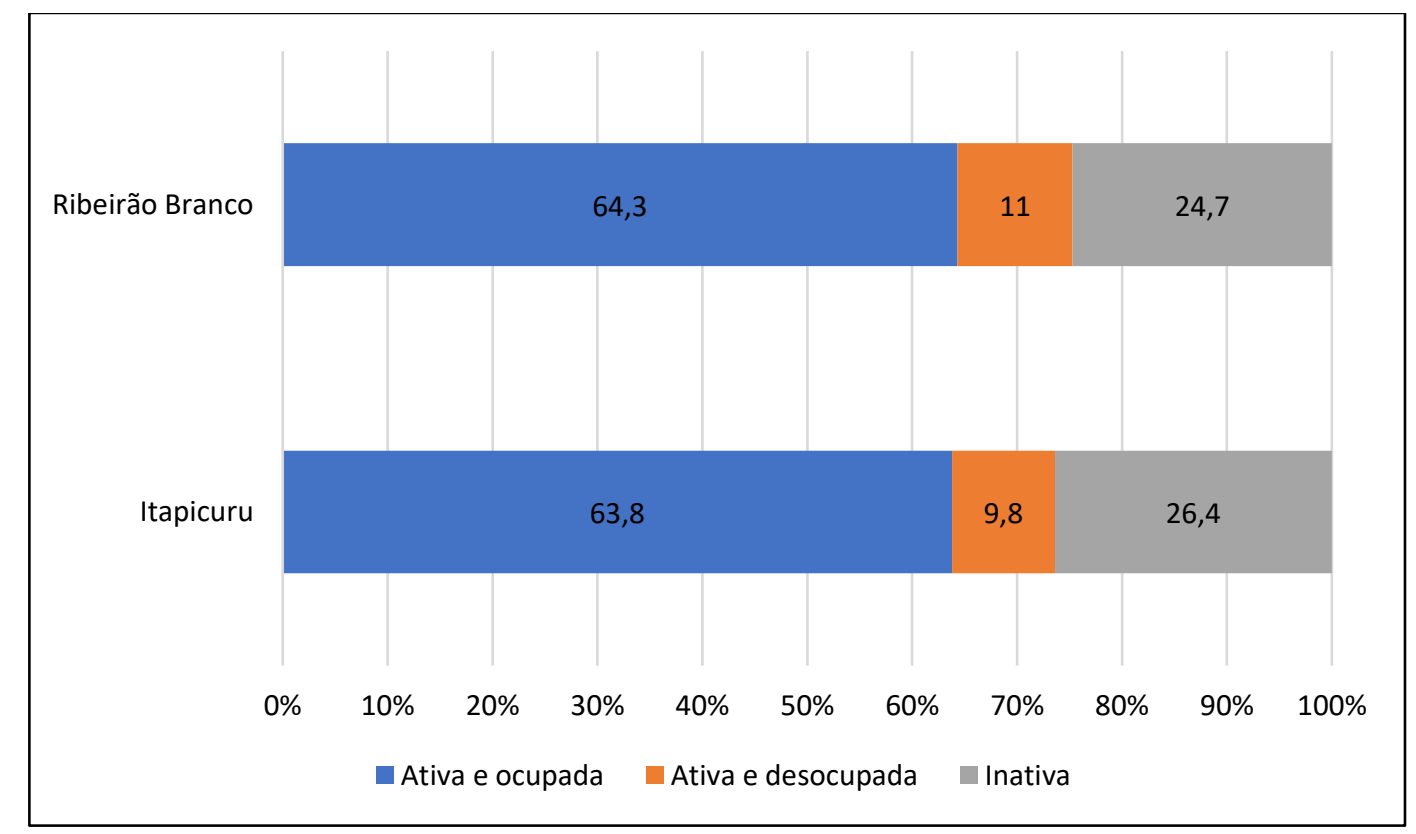

Figura 4.19: Condição de atividade da população nos municípios, em percentual de habitantes com 18 anos ou mais (2010).

Fonte: Preparado pela autora baseado em PNUD (2019). 
Tabela 4.6: Distribuição das empresas nos municípios por setor (CNAE)

\begin{tabular}{|c|c|c|}
\hline Setor CNAE & Itapicuru & Ribeirão Branco \\
\hline $\begin{array}{l}\text { A - Agricultura, pecuária, prod. florestal, pesca e } \\
\text { aquicultura }\end{array}$ & 5 & 2017 \\
\hline $\mathrm{B}$ - Indústrias extrativas & 8 & 6 \\
\hline $\mathrm{C}$ - Indústrias de transformação & 190 & 49 \\
\hline $\begin{array}{l}\text { E - Água, esgoto, gestão de resíduos e } \\
\text { descontaminação }\end{array}$ & 7 & 3 \\
\hline F-Construção & 10 & 42 \\
\hline $\begin{array}{l}\text { G - Comércio, reparação veículos automotores e } \\
\text { motocicletas }\end{array}$ & 322 & 580 \\
\hline $\mathrm{H}$ - Transporte, armazenagem e correio & 18 & 41 \\
\hline I - Alojamento e alimentação & 30 & 149 \\
\hline J - Informação e comunicação & 4 & 19 \\
\hline $\begin{array}{l}\mathrm{K} \text { - Atividades financeiras, seguros e ativ. } \\
\text { Relacionadas }\end{array}$ & 4 & 2 \\
\hline L- Atividades imobiliárias & 1 & 0 \\
\hline M - Atividades profissionais, científicas e técnicas & 9 & 14 \\
\hline $\begin{array}{l}\mathrm{N} \text { - Atividades administrativas e serviços } \\
\text { complementares }\end{array}$ & 19 & 48 \\
\hline $\mathrm{O}$ - Adm. Pública, defesa e seguridade social & 8 & 6 \\
\hline $\mathrm{P}$ - Educação & 30 & 5 \\
\hline Q - Saúde humana e serviços sociais & 5 & 7 \\
\hline $\mathrm{R}$ - Artes, cultura, esportes e recreação & 12 & 5 \\
\hline $\mathrm{S}$ - Outras atividades de serviços & 153 & 96 \\
\hline Total & 835 & 3079 \\
\hline
\end{tabular}

Fonte: ECONODATA, 2019 


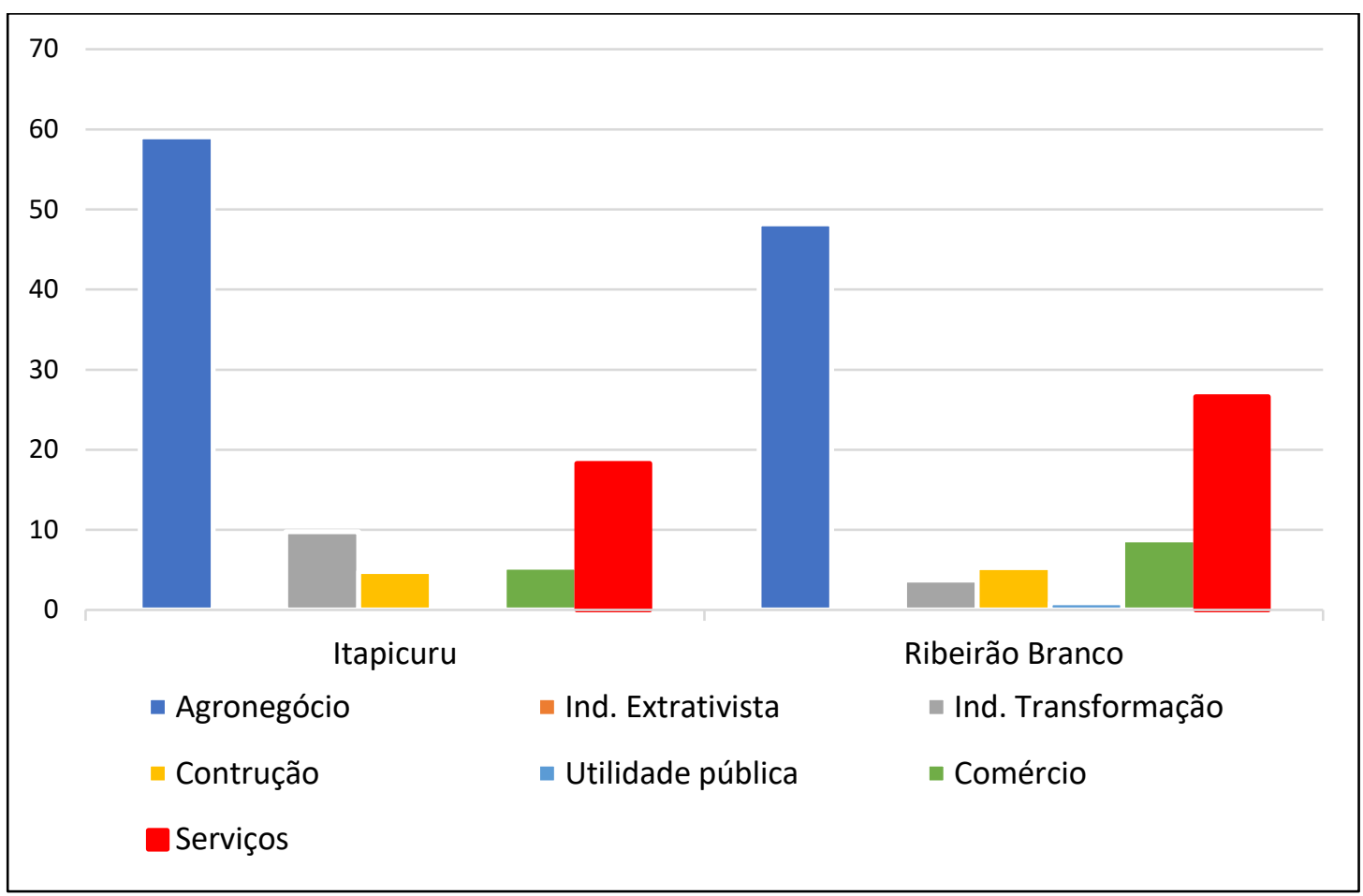

Figura 4.20: Distribuição dos habitantes ocupados com 18 anos ou mais, por setor, em 2010. Fonte: Preparado pela autora baseado em PNUD (2019).

Outra questão a ser observada é que tipo de trabalho as pessoas que se dizem ocupadas exercem. A figura 4.21 mostra em percentuais e de forma comparativa o tipo de trabalho de pessoas com 10 anos de idade ou mais, que estavam ocupadas na semana de referência da pesquisa realizada pelo Censo 2010.

Enquanto empregados sem registro na Carteira de Trabalho e Previdência Social - CTPS em ambos os municípios estava em torno de 30\%, indicando a informalidade do trabalho nos municípios, chama a atenção a desigualdade entre trabalhadores por conta própria e para consumo, muito elevado em Itapicuru, e por outro lado, empregados formais em Ribeirão Branco. Enquanto os empregados com registro na CTPS estão amparados pela legislação trabalhista, os sem registro, os que produzem para consumo e os que trabalham por conta própria ficam à mercê da situação econômica e da conjuntura local, dificultando elevação na qualidade de vida de forma permanente. 


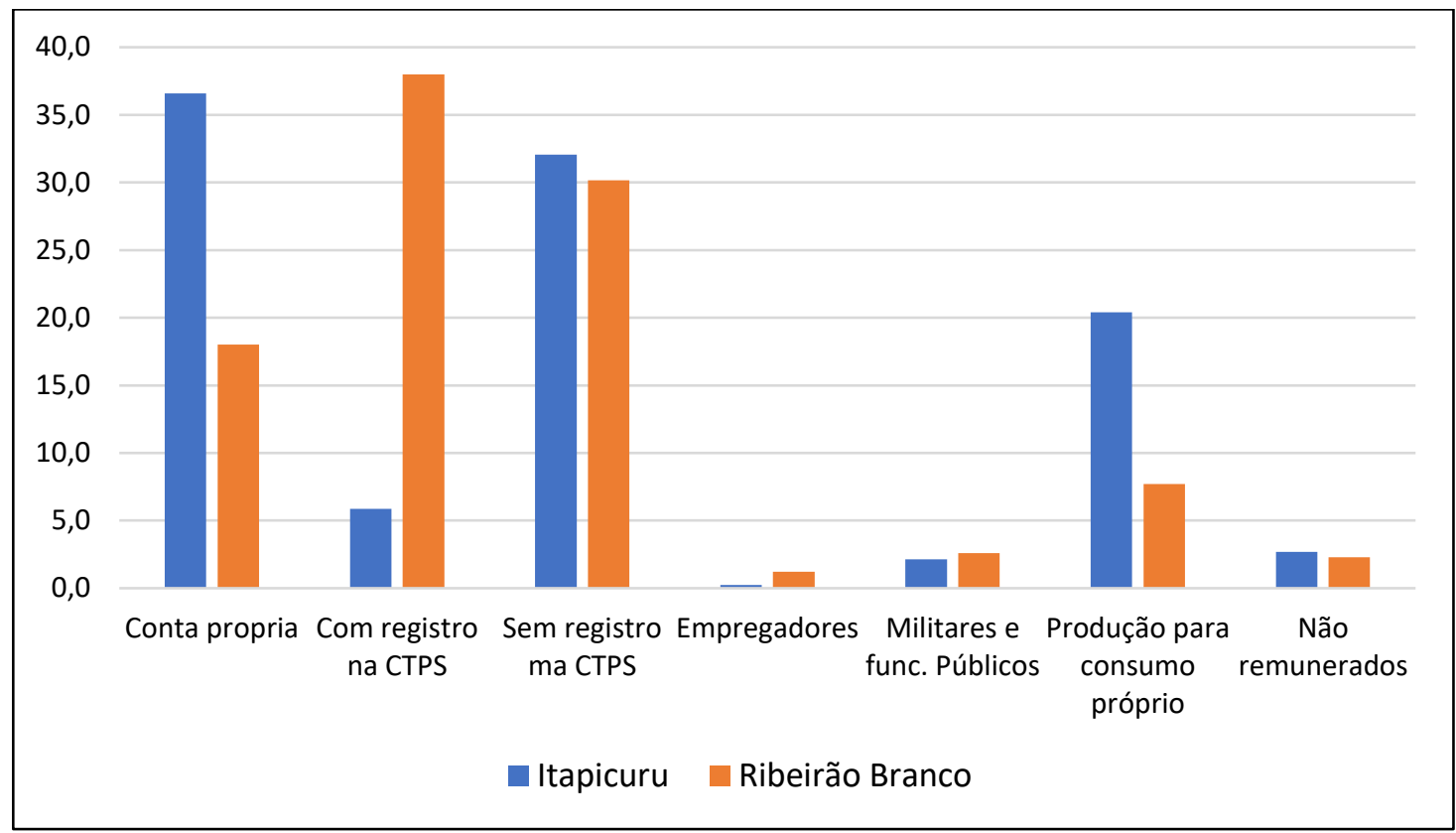

Figura 4.21: Distribuição percentual dos habitantes ocupados com 10 anos ou mais por tipo de trabalho, em 2010.

Fonte: Preparado pela autora baseado em IBGE (2019).

No quesito renda é onde se nota como Itapicuru está numa situação mais crítica. O Índice de Gini, que quantifica a desigualdade e concentração de renda, mostra isso. Valores próximos de 1 indicam maior desigualdade de distribuição de renda. Esse fato pode ser visto, nos valores de renda da população (dados de 2010) mostrados a seguir. Em Itapicuru, quase $84 \%$ de ocupados tem renda até um salário-mínimo, na cidade paulista esse percentual é 38, além de serem cidades com uma população pobre, a desigualdade regional assola fortemente.

Tabela 4.7: Comparativo de renda (2010) da população ocupada com 18 anos ou mais nos municípios estudados.

\begin{tabular}{|l|c|c|}
\hline & Itapicuru & Ribeirão Branco \\
\hline Renda per capita -R\$ & 185,70 & 318,44 \\
\hline \% de ocupados com renda até 1 S.M. & 83,78 & 38,19 \\
\hline \% de ocupados com renda até 5 S.M. & 99,23 & 98,48 \\
\hline Índice de Gini & 0,54 & 0,46 \\
\hline
\end{tabular}

Fonte: PNUD (2019). 


\subsection{VULNERABILIDADE SOCIAL}

Embora seja um termo de difícil conceituação, a vulnerabilidade social tem caráter multidimensional que remete a uma condição de fragilidade material e/ou moral, de indivíduos geralmente à margem da sociedade, principalmente por fatores socioeconômicos (CARMO \& GUIZARDI, 2018).

Alguns indicadores falam por si sobre o tema.

Tabela 4.8: Vulnerabilidade social comparativa entre os municípios (2010).

\begin{tabular}{|l|c|c|}
\hline & Itapicuru & Ribeirão Branco \\
\hline $\begin{array}{l}\text { \% pessoas entre 15 e 24 anos que não estudam, } \\
\text { não trabalham }\end{array}$ & 21,23 & 20,08 \\
\hline$\%$ vulneráveis à pobreza & 79,06 & 59,29 \\
\hline$\%$ pessoas com 18 anos ou mais, sem & 81,92 & 54,03 \\
\hline $\begin{array}{l}\text { fundamental completo e em ocupação informal } \\
\% \text { crianças até } 14 \text { anos extremamente pobres }\end{array}$ & 43,56 & 11,91 \\
\hline
\end{tabular}

Fonte: PNUD (2019).

Um quinto das pessoas em ambas as cidades, com idade entre 15 e 24 anos, nem estudam e nem trabalham. Jovens que vivem em situação delicada pois podem ser influenciados para o crime ou se colocarem em situação de risco.

O percentual de vulneráveis à pobreza, ou seja, pessoas com renda domiciliar per capita de $\mathrm{R} \$ 255,00$ mensais (valores de 2010) é de quase $80 \%$ em Itapicuru e $60 \%$ em Ribeirão Branco. Números muito altos, mas sempre a cidade baiana revelando a desigualdade regional, com o desfavorecimento do nordeste do país.

Em Itapicuru, aproximadamente $82 \%$ de pessoas com 18 anos ou mais, não possuem ensino fundamental completo e encontram-se em ocupação informal, ou seja, são adultos com baixa escolarização, atuando no mercado de trabalho informal, sem os direitos trabalhistas e consequentemente sem grandes perspectivas de elevação na qualidade de vida sua e dos familiares. Ribeirão Branco apresenta 54\% nessa condição, o que também não é um número positivo.

A cidade baiana também mostra um percentual grande de crianças até 14 anos extremamente pobres, onde a renda domiciliar per capita é menor que $\mathrm{R} \$ 70,00$. Quase metade das crianças atendem essa condição. Juntando esses indicadores é possível perceber 
vulnerabilidade social em ambas as cidades, porém muito acentuada na cidade nordestina, onde há um número significativos que tem renda muito baixa, não estudam, não trabalham, num cenário sem perspectivas significativas caso não sejam tomadas ações vigorosas para alterar o status quo.

\subsection{TERRITÓRIO E AMBIENTE}

Dados de 2010, utilizados para o cálculo do IDHM dos municípios, mostram as deficiências na condição de vida das pessoas, a partir da infraestrutura de água encanada, acesso à energia elétrica e coleta de lixo.

Falando em abastecimento de água, os dois municípios estão com mais de $60 \%$ dos domicílios atendidos pela rede de abastecimento. Vê-se também algumas regionalidades como o armazenamento da água de chuva em cisternas, fato comum no Nordeste, que não tem um ciclo de chuvas bem distribuído ao longo do ano e, no caso da cidade paulista, o abastecimento via poço na propriedade, uma vez que a região se localiza sobre o Aquífero Cristalino.

Itapicuru apresenta, segundo dados de 2010, 11,4\% de domicílios com esgotamento sanitário adequado, 58,6\% de domicílios urbanos em vias públicas com arborização e 14,4\% de domicílios urbanos em vias públicas com urbanização adequada, onde há presença de bueiro, calçada, pavimentação e meio-fio. A Embasa - Empresa Baiana de Águas e Saneamento, empresa de economia mista sendo o maior acionista o Governo do Estado da Bahia, é responsável pela prestação de serviços de abastecimento de água (captação, tratamento e distribuição) mas, segundo relatório de municípios atendidos em 2018, o serviço de esgotamento sanitário não é prestado nessa cidade (EMBASA, 2019). Em relatos à pesquisadora, alguns moradores informaram sentir forte odor de esgoto em regiões baixas da cidade.

Em Ribeirão Branco são 51,2\% de domicílios com esgotamento sanitário adequado, 10,7\% de domicílios urbanos em vias públicas com arborização e 4,6\% de domicílios urbanos em vias públicas com urbanização adequada (IBGE, 2019). A SABESP - Companhia de Saneamento Básico do estado de São Paulo, empresa de economia mista sendo o maior acionista o Governo do Estado de São Paulo, é responsável pela prestação de serviços de abastecimento de água (captação, tratamento e distribuição), coleta e tratamento de esgotos de Ribeirão Branco (SABESP, 2017). 

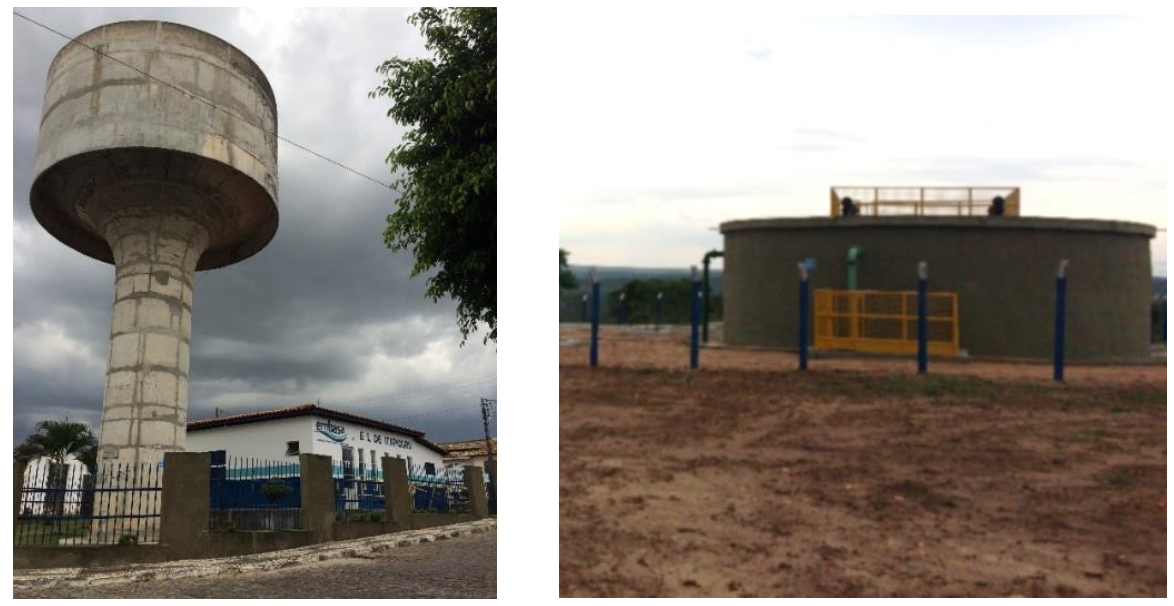

Figura 4.22: Escritório local e caixa dágua EMBASA - Itapicuru Fonte: a autora em visita de campo (2018).
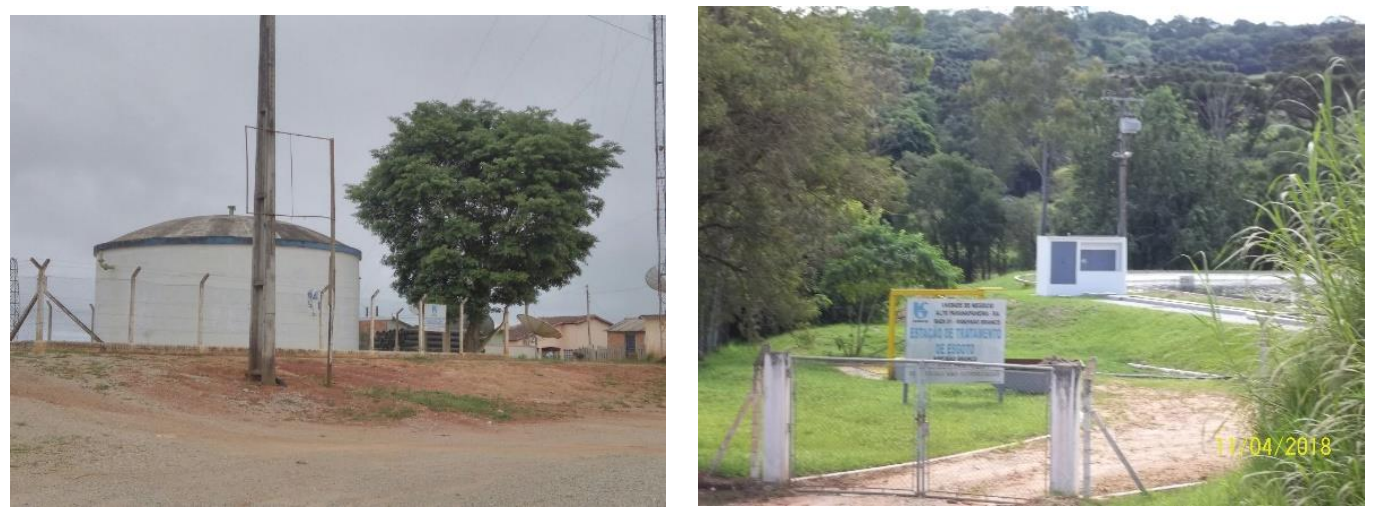

Figura 4.23: Caixa d'água e Estação de Tratamento de Esgoto SABESP - Ribeirão Branco Fonte: a autora em visita de campo (2018).

Tabela 4.9: Comparativo de indicadores de habitação (2010) nos municípios estudados.

\begin{tabular}{|l|c|c|}
\hline & Itapicuru & Ribeirão Branco \\
\hline \% domicílios com água encanada & 78,66 & 89,31 \\
\hline \% domicílios com energia elétrica & 92,77 & 99,54 \\
\hline \% domicílios com coleta de lixo & 87,16 & 98,30 \\
\hline
\end{tabular}

Fonte: PNUD (2019).

O Censo de 2010 também levantou dados sobre destino do lixo e abastecimento de água dos domicílios. As respostas dadas são apresentadas nas figuras 4.24 e 4.25.

Na situação do município de Itapicuru chamam atenção o baixo percentual de domicílios com coleta (abaixo de 40\%), quase o mesmo percentual é queimado na propriedade, indicando falta de conhecimentos ambientais e a situação onde quase $18 \%$ indicam jogar aleatoriamente 
o lixo em terreno ou logradouro, criando ambiente propício para a propagação de pragas e vetores de doenças. Ribeirão Branco, por sua vez, tem mais de 70\% dos domicílios com coleta, mas $23 \%$ queimam na propriedade. Em ambos os casos se percebe que a população não tem conhecimento ou estímulo para o aproveitamento dos resíduos, com separação para reciclagem e outras utilizações dos resíduos orgânicos como compostagem, por exemplo.
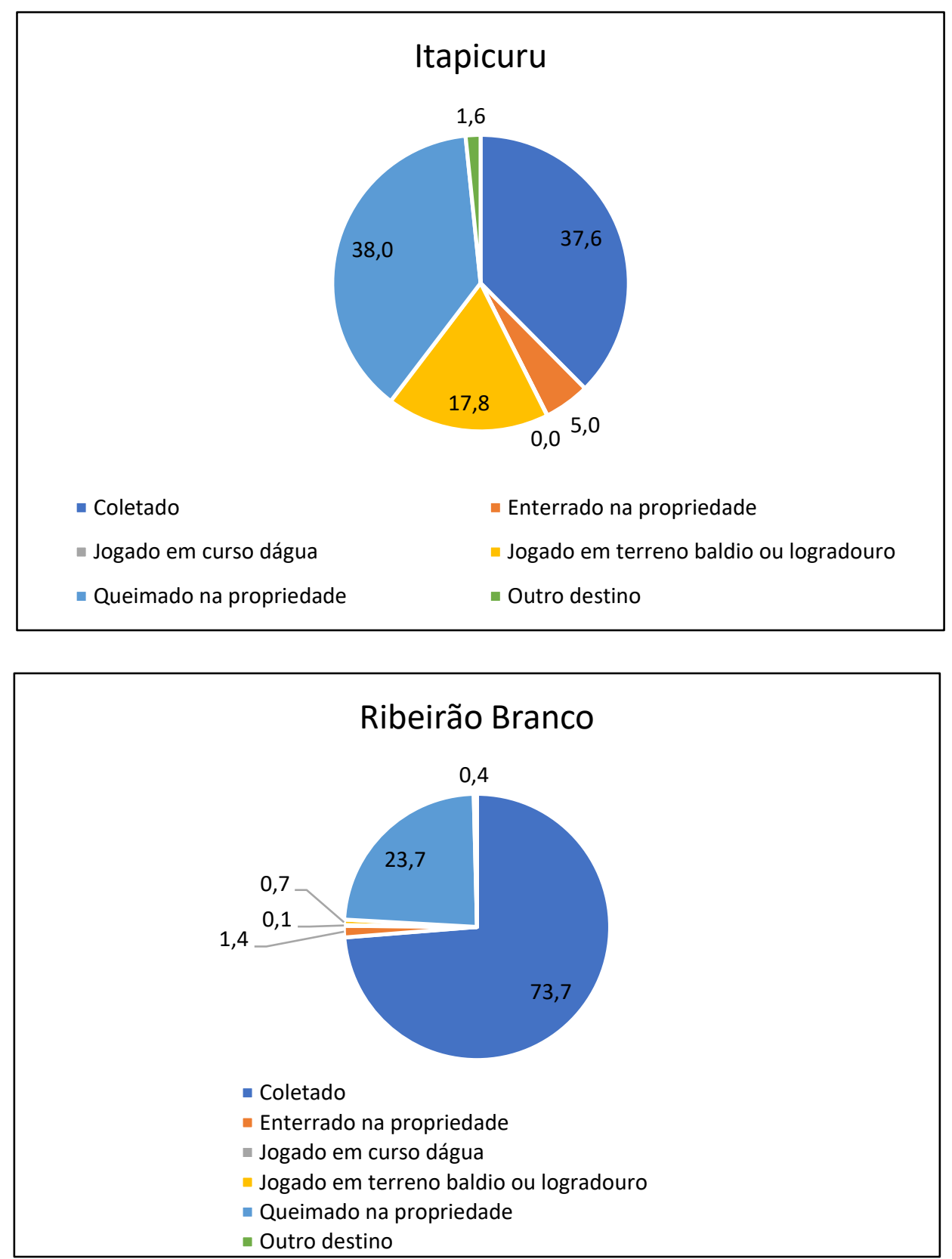

Figura 4.24: Percentual da disposição do lixo dos domicílios em ambos municípios, em 2010.

Fonte: Preparado pela autora baseado em IBGE (2019). 
O Panorama Abrelpe 2018/2019 (Associação Brasileira de Empresas de Limpeza Pública e Resíduos Especiais) traz dados mais atualizados sobre os resíduos , indicando que no Brasil houve retomada da geração (79 milhões de toneladas), com 92,01\% de cobertura de coleta sendo que 59,5\% teve como destino aterros sanitários, 17,5\% seguiram para lixões e 22,3\% para aterros controlados, ou seja, aqueles que não possuem conjunto de medidas e sistemas necessários para a proteção do meio ambiente contra danos e degradações, impactando diretamente na saúde de milhares de pessoas (ABRELPE, 2019). Infelizmente esse relatório não desce ao detalhamento por municípios, mas dados regionais reforçam as desigualdades inclusive na destinação final do resíduo sólido, conforme visto na tabela 4.10.

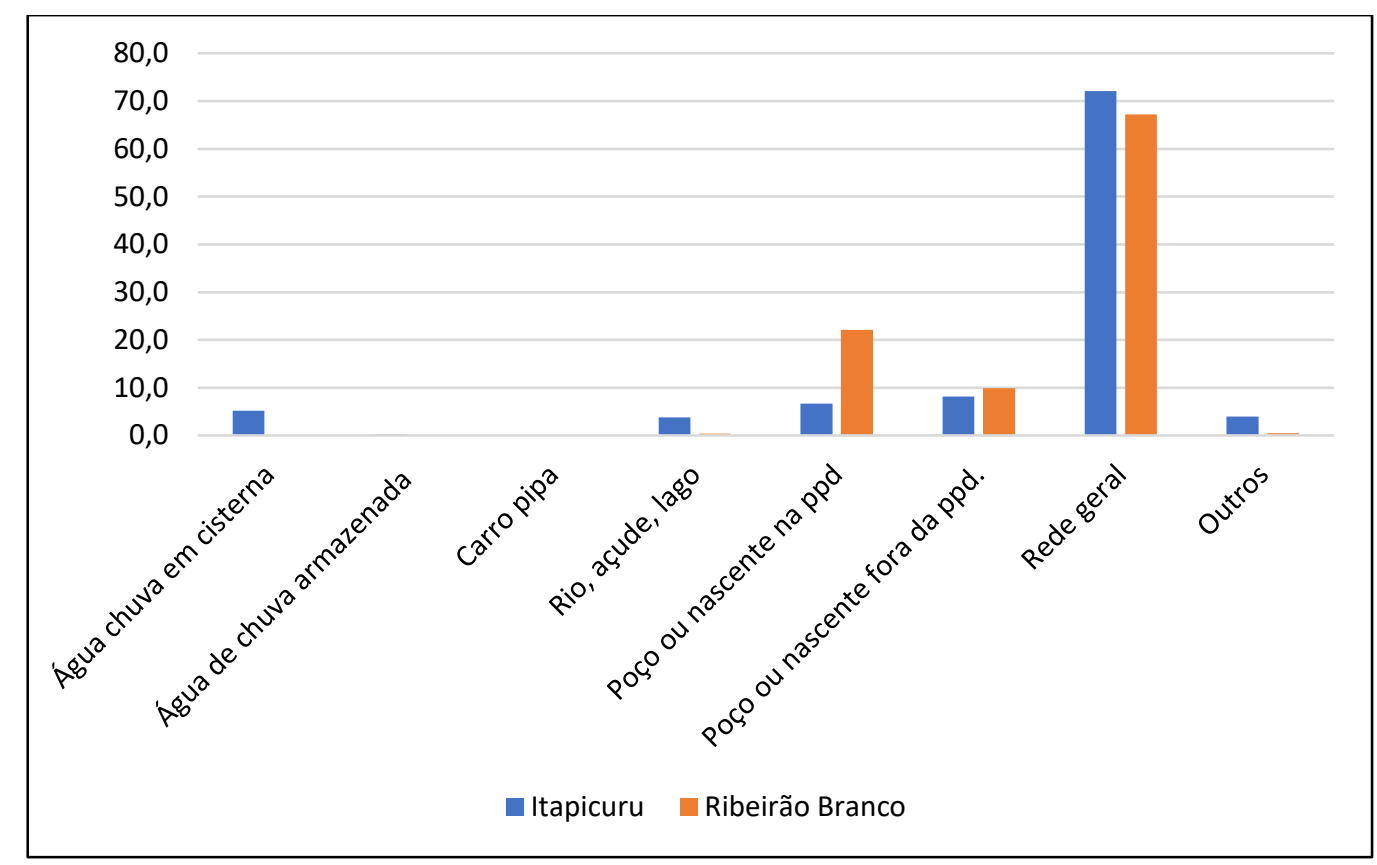

Figura 4.25: Percentual da fonte de abastecimento de água dos domicílios em ambos municípios, em 2010.

Fonte: Preparado pela autora baseado em IBGE (2019).

Tabela 4.10: Comparativo de destinação de resíduos sólidos urbanos por regiões (2018) dos municípios estudados.

\begin{tabular}{|l|c|c|}
\hline Destino do RSU (\%) & Nordeste & Sudeste \\
\hline Aterro sanitário & 35,6 & 72,7 \\
\hline Aterro controlado & 32,9 & 17,2 \\
\hline Lixão & 31,5 & 10,1 \\
\hline
\end{tabular}

Fonte: Abrelpe (2019). 


\subsection{ENERGIA E SUA UTILIZAÇÃO}

A energia, item fundamental para desenvolvimento e bem-estar das sociedades, pode ser utilizada para fins produtivos ou não. Considerando o bem-estar das famílias, o Censo 2010 fez levantamento de alguns bens duráveis existentes nas residências, apresentado de forma percentual na figura 4.26. Percebe-se a importância da energia elétrica para o uso da maioria dos equipamentos mencionados.

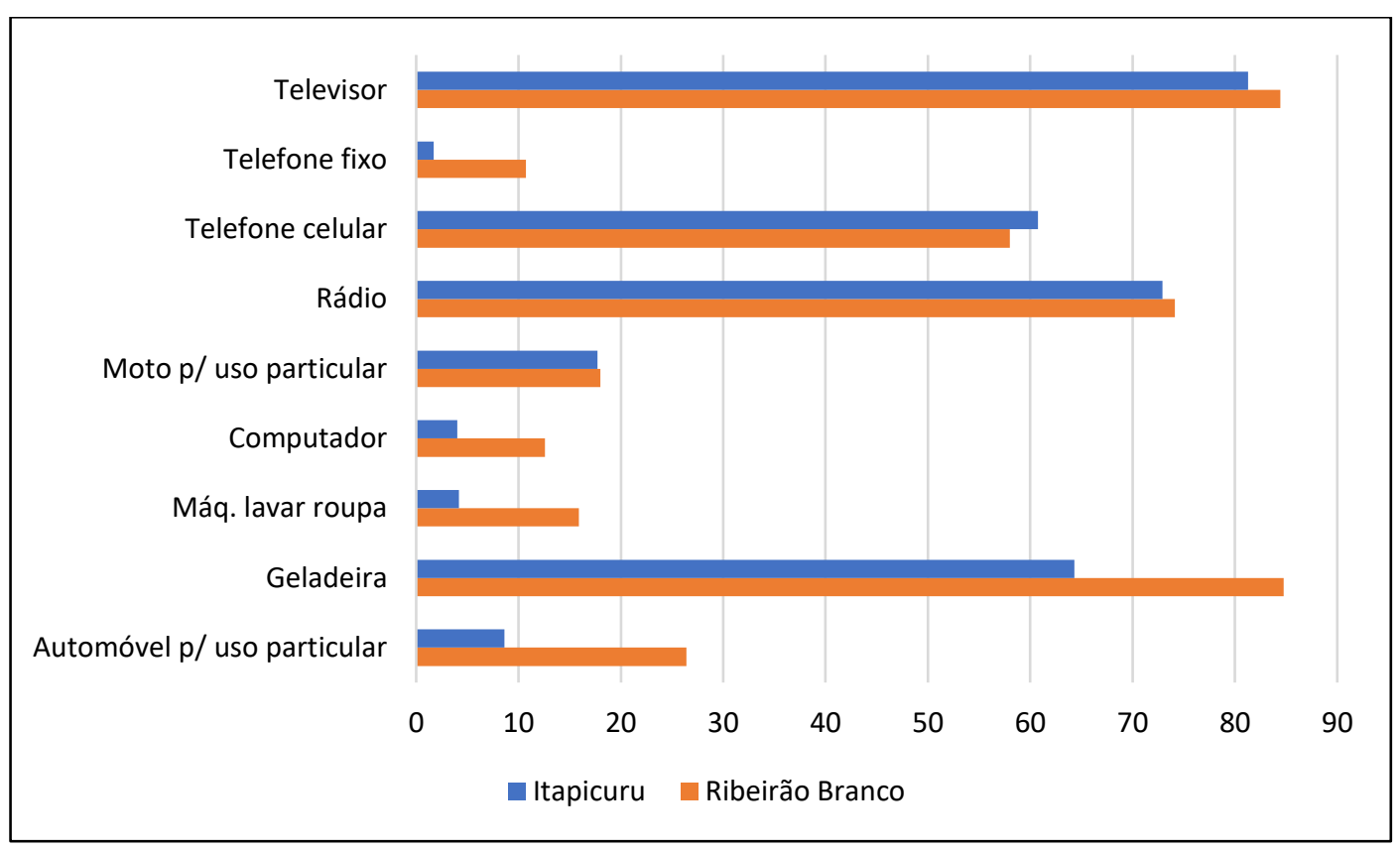

Figura 4.26: Percentual de domicílios particulares permanentes com existência de alguns bens duráveis em ambos os municípios, em 2010.

Fonte: Preparado pela autora baseado em IBGE (2019).

No município de Itapicuru, a concessionária de energia é a Coelba - Companhia de Eletricidade do Estado da Bahia, empresa inicialmente pública que hoje é privada de capital misto pertencendo ao grupo Neoenergia, grupo nacional com forte participação de capital espanhol (Iberdrola). A subestação que atende Itapicuru pertence à Companhia Hidrelétrica do São Francisco - CHESF e não é exclusiva para este município, situando-se na cidade vizinha Olindina (230/13,8 kV com potência instalada 40 MVA) (COELBA, 2019; CHESF, 2019).

Em Ribeirão Branco, a concessionária de energia é a Elektro, empresa inicialmente pública que hoje pertence ao grupo Neoenergia. Em 2015 a concessionária inaugurou subestação de energia elétrica na cidade totalmente digitalizada $(34,5 / 13,8 \mathrm{kV}$, potência instalada 6,25 MVA) (ELEKTRO, 2019). 


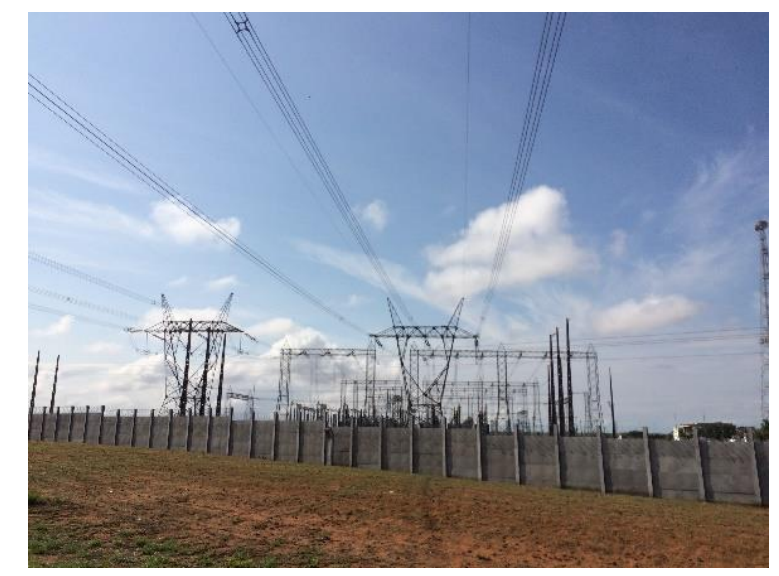

Figura 4.27: Subestação de Energia Elétrica Olindina - CHESF Fonte: a autora em visita de campo (2018).

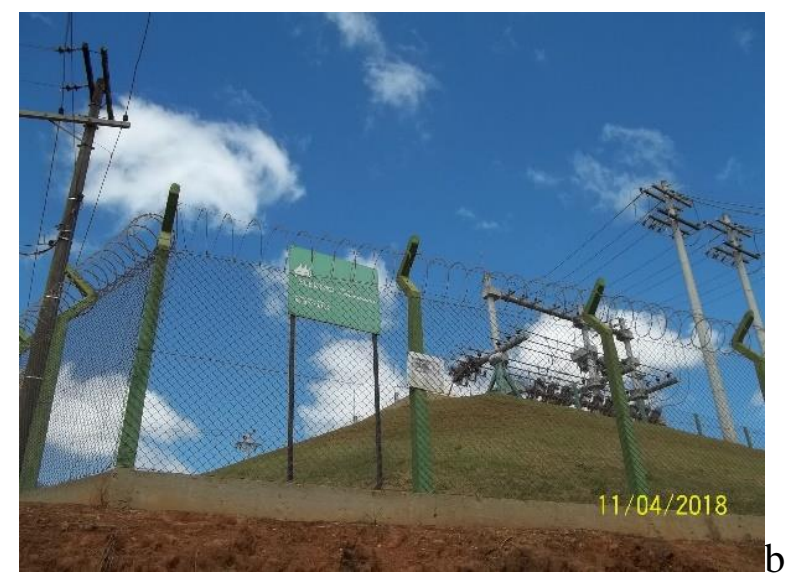

Figura 4.28: Subestação de Energia Elétrica Ribeirão Branco - ELEKTRO Fonte: a autora em visita de campo (2018).

O consumo de energia elétrica para os diversos fins tem como uma das variáveis para seu crescimento a tarifa, uma vez que ao se tornar mais impactante nos orçamentos, alternativas energéticas, tecnológicas ou mesmo a redução de consumo costumam ser buscadas pela população. As tarifas praticadas pelas concessionárias nos municípios estudados, sem tributos como ICMS (Imposto sobre Circulação de Mercadorias e Serviços), PIS/PASEP (Programa de Integração Social e o Programa de Formação do Patrimônio do Servidor Público) e COFINS (Contribuição para o Financiamento da Seguridade Social), sem taxa de iluminação pública e sem adicional de Bandeira Tarifária encontram-se na tabela 4.11.

Tabela 4.11: Tarifas convencional de energia elétrica, sem tributos, nos municípios estudados.

\begin{tabular}{|l|l|l|}
\hline & Itapicuru & Ribeirão Branco \\
\hline Tarifa energia elétrica $(\mathrm{R} \$ / \mathrm{kWh})$ & 0,552 & 0,602 \\
\hline Vigência & Abril/2019 & Agosto/2018 \\
\hline
\end{tabular}

Fonte: Aneel (2019). 
As figuras 4.29 e 4.30 trazem série histórica a partir de 2010 do consumo de energia elétrica por classe, nos municípios estudados.

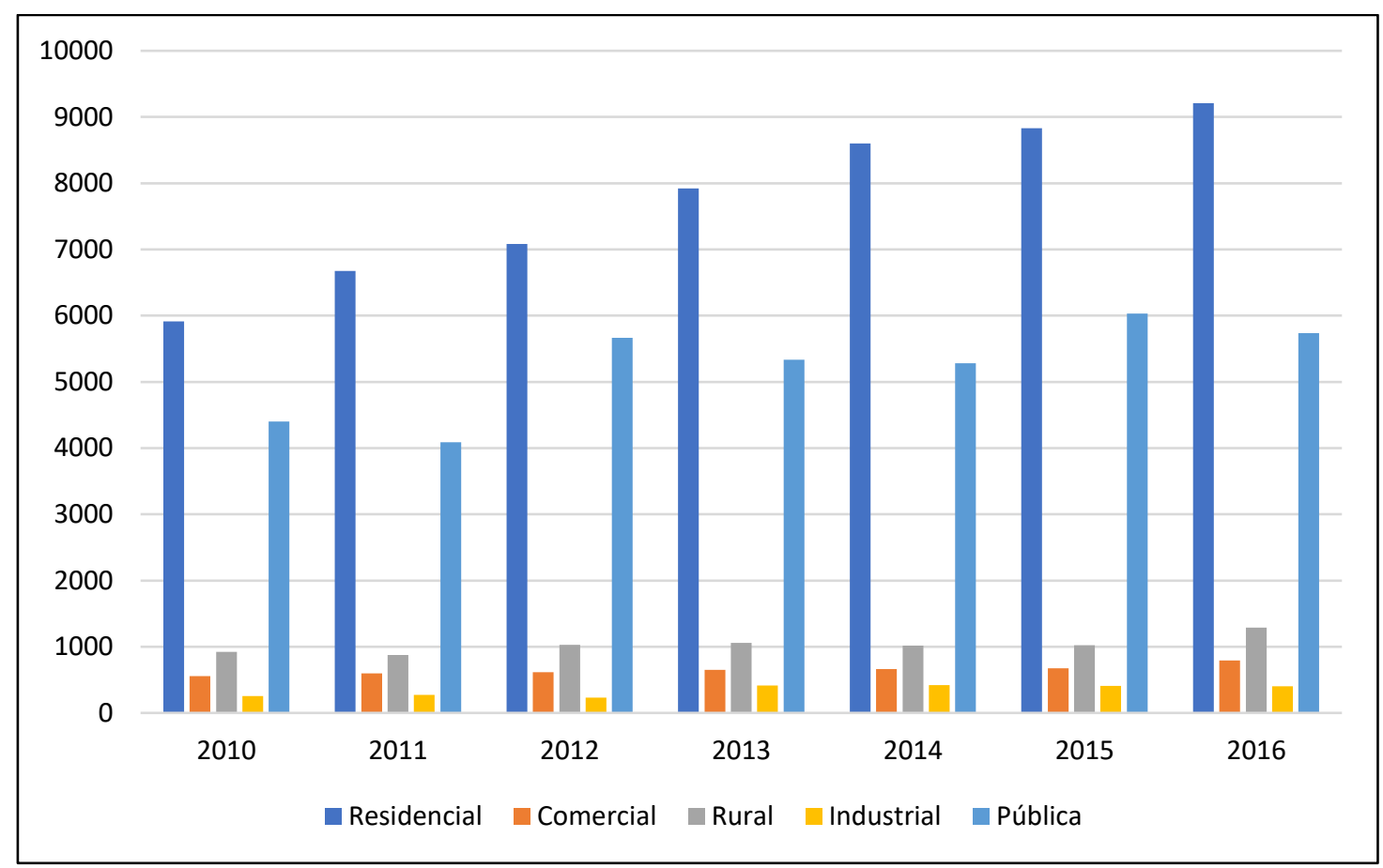

Figura 4.29: Consumo (MWh) por classe e por ano entre 2010 - 2016 em Itapicuru. Fonte: Bahia. SEI. (2019).

Em Itapicuru, o consumo residencial vem crescendo a cada ano, seguindo as maiores demandas por energia da sociedade e o crescimento da população no município. Apresentam discreto aumento de consumo as classes comerciais e industriais, demonstrando certa estagnação dos setores. O setor rural pouco cresceu nesses 6 anos apresentados. Percebe-se que o uso produtivo da energia não tem se expandido, não propiciando condições para elevação de renda e prosperidade na cidade.

Observando o consumo por classe de consumidor em Ribeirão Branco, vê-se diminuição do consumo industrial, estagnação do consumo rural e ligeira queda no consumo residencial não esquecendo que a população no município vem decrescendo. Apenas o setor comercial mostra aumento do consumo. Também aqui o uso produtivo da energia não é percebido como alavanca para elevação de renda e qualidade de vida da população.

O número de consumidores por classe, em cada município, é apresentado na tabela 4.12. 


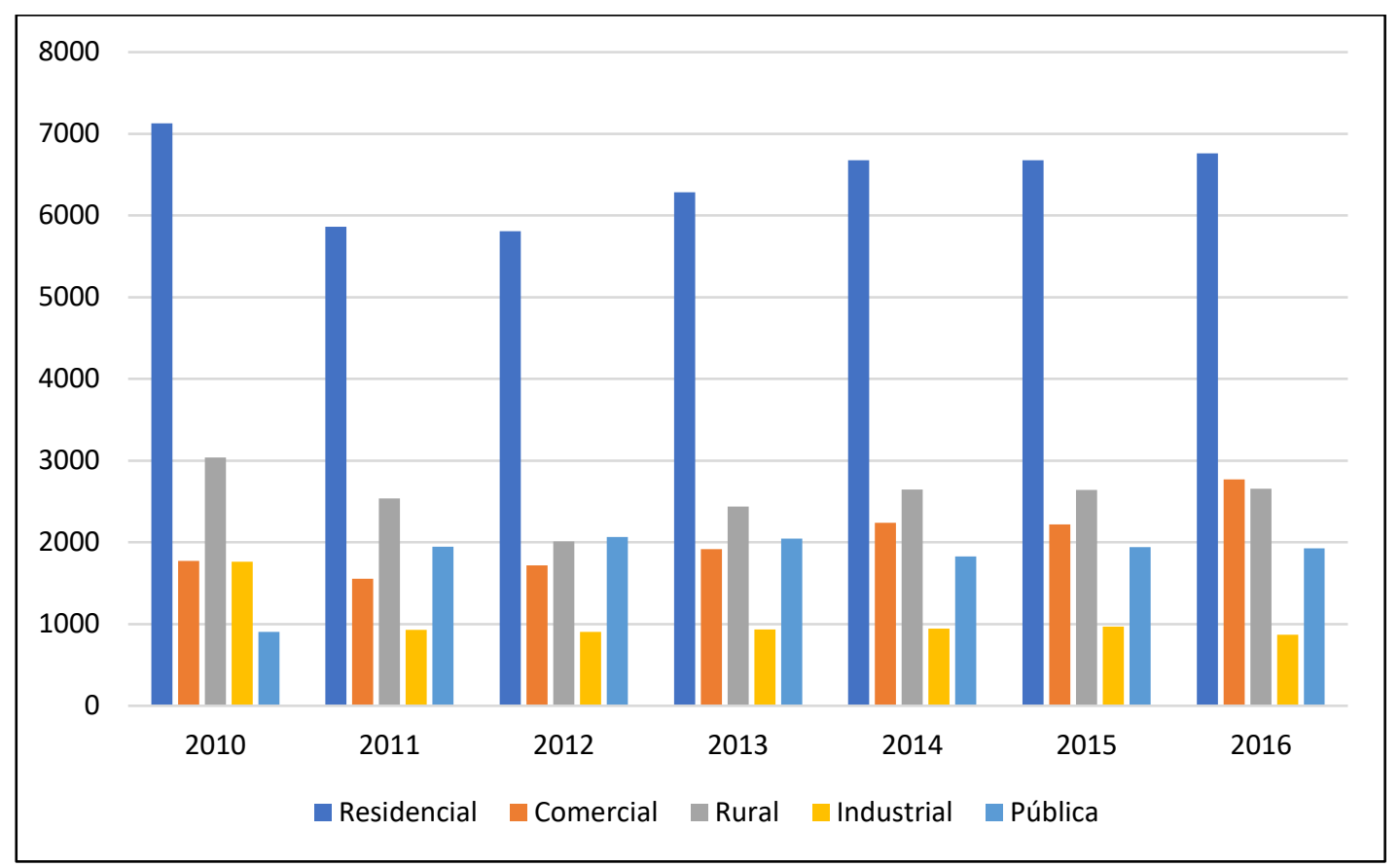

Figura 4.30: Consumo (MWh) por classe e por ano entre 2010 - 2016 em Ribeirão Branco. Fonte: S.Paulo - SIMA (2019).

Tabela 4.12: Número de consumidores em 2016 por classe nas cidades estudadas.

\begin{tabular}{|l|c|c|}
\hline Classe de consumidor & Itapicuru* & Ribeirão Branco** \\
\hline Residencial & 11.471 & 5.347 \\
\hline Comercial & 350 & 327 \\
\hline Rural & 677 & 1.032 \\
\hline Industrial & 18 & 23 \\
\hline Pública & 226 & 102 \\
\hline
\end{tabular}

Fonte: Preparado pela autora baseado em *Bahia - SEI (2019) e **SP - SIMA (2019).

\subsection{LAZER, ESPORTE E CULTURA}

O bem-estar, que antes significava disponibilidade de bens materiais, atualmente se relaciona com dimensões menos tangíveis como segurança, dignidade pessoal, satisfação com a vida, alegria e oportunidade para atingir objetivos pessoais, entre outros (SOUSA; GALANTE; FIGUEIREDO, 2003). Nesse contexto, lazer, esporte e cultura assumem papel importante na prevenção de doenças e promoção da saúde física e mental.

A tabela 4.13 apresenta dados de 2014, coletados na Pesquisa de Informações Básicas Municipais, Suplemento de Cultura (IBGE, 2019). 
Tabela 4.13: Aspectos de cultura e lazer nos municípios estudados. Dados de 2014.

\begin{tabular}{|l|c|c|}
\hline & Itapicuru & Ribeirão Branco \\
\hline Jornal impresso local & Não & Sim \\
\hline Rádio AM & Sim & Não \\
\hline Rádio FM & Sim & Não \\
\hline Rádio Comunitária & Sim & Sim \\
\hline Canais TV aberta captada & 4 & Mais de 5 \\
\hline Biblioteca pública & 1 & 1 \\
\hline Teatro ou sala de espetáculo & Não & Não \\
\hline
\end{tabular}

Fonte: Pesquisa de Informações Básicas Municipais, Suplemento de Cultura - 2014. (IBGE, 2019)

Atualmente, segundo relatos de moradores à pesquisadora, a internet é meio de comunicação muito utilizado devido a facilidades através da telefonia celular. Em Itapicuru são 8 Estações Rádio Base (ERBs) e em Ribeirão Branco existem 9 ERBs conforme dados de maio de 2019, fornecidos pela Associação Brasileira de Telecomunicações (TELEBRASIL, 2019). Em nenhum dos municípios existe cinema.

Ambos os municípios contam com instalações poliesportivas municipais e calendário de eventos para esporte e lazer, segundo a Pesquisa de Informações Básicas Municipais, Suplemento de Esporte - 2016. (IBGE, 2019).
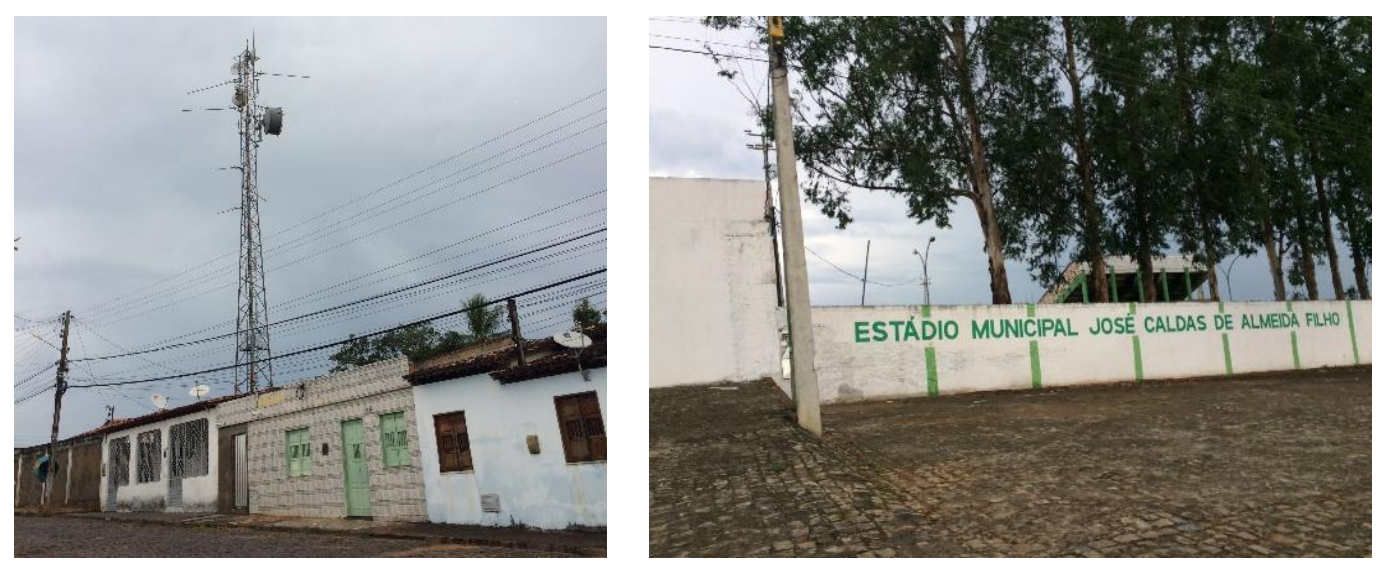

Figura 4.31: Itapicuru: vista de ERB (esq.) e Estádio Municipal de Esportes (dir.). Fonte: a autora em visita de campo (2018). 

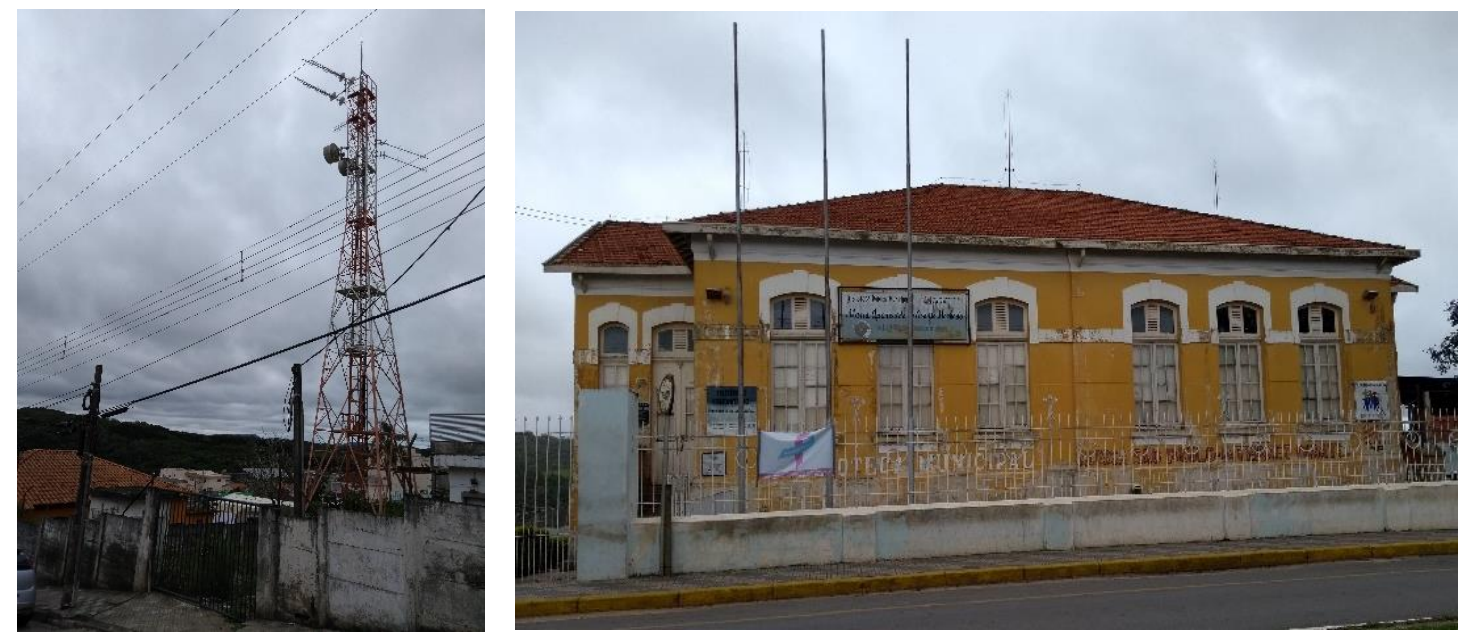

Figura 4.32: Ribeirão Branco: vista de ERB (esq.) e biblioteca Municipal (dir.) Fonte: a autora em visita de campo (2018).

Os municípios desenvolvem ações de fomento ao artesanato. Em Itapicuru, vê-se como expressão cultural de artesanato: o bordado, artigos de barro e couro. Em Ribeirão Branco, trabalhos com fios e fibras vegetais segundo a Pesquisa de Informações Básicas Municipais, Suplemento de Cultura - 2014. (IBGE, 2019).

\subsection{OUTROS ASPECTOS MUNICIPAIS}

A Pesquisa de Informações Básicas Municipais 2017 traça o perfil dos municípios brasileiros sob vários aspectos. Nas cidades envolvidas deste estudo, o setor agropecuário recebe apoio através de programas municipais só em Ribeirão Branco para mudas e sementes, não havendo legislação municipal para uso do solo rural nem em Itapicuru, nem em Ribeirão Branco. Somente em Itapicuru a prefeitura desenvolve programa ou ações de apoio ao associativismo, mas existem sindicatos rurais nos dois municípios. Somente em Itapicuru há associações de produtores e cooperativas (IBGE, 2019). Essas associações e cooperativas podem ser importantes meios para divulgação do aproveitamento energético de resíduos.

Ainda com dados da mesma pesquisa, mas sobre o maio-ambiente, em Itapicuru há uma secretaria municipal exclusiva para essa área, o que não ocorre em Ribeirão Branco. Ambas as cidades não participam de consórcio intermunicipal para realização de ações na área ambiental, as duas possuem um Conselho Municipal de Meio Ambiente, mas não possuem Fundo Municipal para tal. Nenhuma das cidades possui Plano de Gestão Integrada de Resíduos Sólidos, nos termos da Política Nacional de Resíduos Sólidos, não participam de nenhum programa em parceria com o Governo Federal na área ambiental. Somente Itapicuru, segundo a pesquisa, possui legislação municipal para gestão de bacias hidrográficas, legislação sobre poluição ambiental e sobre adaptação e/ou mitigação de mudanças do clima (IBGE, 2019). 
Ribeirão Branco participa atualmente do Programa Município Verde Azul do Governo do Estado de São Paulo. Esse programa, criado em 2017, tem como propósito estimular e auxiliar as prefeituras na elaboração de políticas públicas voltadas para o desenvolvimento sustentável, medindo e apoiando a eficiência da gestão ambiental. No ranking anual, entre os 645 municípios paulistas, Ribeirão Branco situa-se em $438^{\circ}$ lugar, denotando uma grande deficiência ainda nesta área (SÃO PAULO, 2019).

\subsection{CONCLUSÕES DO CAPÍTULO}

Ambos os municípios possuem a maior parte da população vivendo em áreas rurais, sendo que Itapicuru tem quase o dobro de habitantes de Ribeirão Branco, que tem sua população diminuindo segundo dados do IBGE. O IDHM das duas cidades é abaixo do valor nacional, sendo que Itapicuru está numa situação pior. Dentre as três dimensões, a educação é que contribui de forma mais negativa para o resultado da cidade baiana, embora também possua números menores em renda e saúde.

Em Itapicuru são quase 50\% dos adultos analfabetos, enquanto em Ribeirão Branco são aproximadamente 15\%. Na área da saúde, nos dois municípios a situação é precária e equivalente. As duas cidades têm a maior parte da população ocupada no agronegócio, sendo que a renda per capita em Itapicuru é quase a metade da de Ribeirão Branco.

O acesso à energia em ambas as cidades é acima de 90\%, com coleta de lixo de 87 e $98 \%$, acesso à água encanada com 78 e $89 \%$ e coleta de esgoto 11 e $51 \%$, sendo que sempre os percentuais mais baixos correspondem à cidade situada no nordeste brasileiro.

A situação em Ribeirão Branco não é boa, mas a situação torna-se muito mais crítica em Itapicuru, dando um peso maior nos números devido às desigualdades encontradas no país. 


\section{BIOMASSA RESIDUAL E SUAS POSSÍVEIS APLICAÇÕES PARA GERAÇÃO DE ENERGIA}

Como foi visto em capítulo anterior, ambos os municípios estudados possuem vocação para o agronegócio, o que costuma ser uma característica de regiões com menor IDH. Entretanto, na maior parte, os resíduos produzidos não são descartados nem reutilizados de forma adequada. $\mathrm{Na}$ verdade, os resíduos agrícolas são importante fonte de biomassa que podem ser utilizados para a geração descentralizada de energia. Também os dejetos (sólidos e líquidos) de animais, sejam eles criados para abate, produção de leite, ou como matrizes, podem ser aproveitados para o mesmo fim. As vantagens econômicas, sociais e ambientais são inúmeras, como discutido no Projeto BREA (GNESD, 2015), entre elas a disposição correta dos resíduos (agropecuários ou humanos) não acarretando dano ao ambiente (solo e água), produção de energia para atividades produtivas, substituição da lenha e carvão por biogás ou gás de síntese para cocção e aquecimento, favorecendo a saúde das pessoas envolvidas nas atividades, entre outras.

Assim, neste capítulo, são apresentados, discutidos e analisados os resultados do levantamento de campo e de dados estatísticos pesquisados, calculando a disponibilidade de resíduos de biomassa, que incluem resíduos de produção da agricultura e silvicultura, de beneficiamento desses produtos (quando feito no município), dejetos de animas criados em sistema de confinamento, resíduos sólidos urbanos coletados e esgoto coletado nos municípios.

\subsection{PRODUÇÃO AGRÍCOLA}

Agricultura, ou a arte de cultivar a terra, tem como importante característica o tipo de cultura que depende do ciclo genealógico da planta, ou por quanto tempo ela produz. Assim existem as culturas ou lavouras permanentes, aquelas onde não é necessário replantio após a colheita pois a planta permite várias colheitas ao longo da vida útil da lavoura. E, por ouro lado, as culturas ou lavouras temporárias também chamadas de anuais, que estão sujeitas ao replantio após cada colheita pois possuem período de vida curto. Durante seu ciclo de vida, vegetais clorofilados assimilam $\mathrm{CO}_{2}$ e, com a energia luminosa proveniente do sol, produzem vários compostos orgânicos (SANTOS, MARION E SEGATTI, 2009).

As tabelas 5.1 e 5.2 apresentam a produção agrícola municipal de 2017 dos municípios estudados. Considerando a viabilidade técnica e econômica, foram analisadas apenas aquelas 
culturas com produção acima de 1.000 toneladas por ano, conforme metodologia adotada pelo BREA (GNESD, 2015).

Tabela 5.1: Produção anual agrícola municipal de Itapicuru e Ribeirão Branco - culturas permanentes. Dados de 2017.

\begin{tabular}{|l|c|c|c|c|}
\hline \multirow{2}{*}{ Cultura } & \multicolumn{2}{|c|}{ Itapicuru (t) } & \multicolumn{2}{c|}{ Ribeirão Branco (t) } \\
\hline Caqui & Produção (t) & $\begin{array}{c}\text { Área colhida } \\
\text { (ha) }\end{array}$ & Produção (t) & Área colhida \\
(ha)
\end{tabular}

Fonte: IBGE (2019).

Tabela 5.2: Produção anual agrícola municipal de Itapicuru e Ribeirão Branco - culturas temporárias. Dados de 2017.

\begin{tabular}{|l|c|c|c|c|}
\hline \multirow{2}{*}{ Cultura } & \multicolumn{2}{|c|}{ Itapicuru (t) } & \multicolumn{2}{c|}{ Ribeirão Branco (t) } \\
\hline Cebola & Produção (t) & $\begin{array}{c}\text { Área colhida } \\
\text { (ha) }\end{array}$ & Produção (t) & Área colhida \\
\hline Mandioca & - & - & & 2.000 \\
\hline Melancia & 23.500 & 2.000 & 640 & 100 \\
\hline Melão & 4.000 & 150 & 63 & 40 \\
\hline Milho (grão) & 1.100 & 70 & - & 3 \\
\hline Tomate & 34.866 & 8.500 & 50.400 & 7.000 \\
\hline
\end{tabular}

Fonte: IBGE (2019).

A silvicultura, ou a exploração e manutenção de povoação florestal com intuito comercial, pode ter importância ecológica, científica, social, econômica e energética (RIBEIRO e outros, 2002). A produção da silvicultura nos municípios encontra-se na tabela 5.3. 
Tabela 5.3: Produção de Silvicultura em Itapicuru e Ribeirão Branco. Dados de 2017.

\begin{tabular}{|l|c|c|}
\hline & Itapicuru & Ribeirão Branco \\
\hline Eucalipto (ha) & 200 & 6.300 \\
\hline Pinus (ha) & - & 14.700 \\
\hline Outras espécies (ha) & - & 443 \\
\hline Madeira em tora $\left(\mathrm{m}^{3}\right)$ & - & 89.180 \\
\hline Resina (t) & - & 1.148 \\
\hline
\end{tabular}

Fonte: IBGE (2019).

Em Itapicuru, as culturas típicas nordestinas estão presentes como o coco da baia, o caju (castanha) e a mandioca. Destaque para frutas tropicais como melancia, melão e maracujá e, principalmente, laranja. A cidade é um dos grandes produtores desse cítrico no Nordeste.

Ribeirão Branco é grande produtor de tomate do estado, tendo também outras culturas de frutas de mesa como a maçã, pêssego e caqui. Neste município, a silvicultura tem números representativos, sendo a plantação de pinus em maior quantidade para extração da madeira e coleta de resina.

\section{2 RESÍDUOS DA AGRICULTURA}

Como verificado, os municípios selecionados possuem forte atividade agrícola e os resíduos das lavouras podem ser aproveitados para geração de energia, com as vantagens conhecidas. Entretanto, para estimar a geração de resíduos pelas diferentes lavouras, deve-se considerar as especificidades de cada cultura, o que foi elaborado a partir de dados foram coletados na literatura.

\subsubsection{Culturas permanentes}

Caqui (Diospyrus kaki): Delicado e de sabor adocicado, o caqui tem seu consumo principal como fruto de mesa. Introduzido no Brasil no século XIX, o país é o quarto produtor mundial sendo o cultivar Fuyu o de maior importância. A árvore passa por poda de formação e limpeza; a partir do terceiro ano em média, ocorre a poda de frutificação (LOPES et al, 2014). Neste estudo considerou-se como taxa de resíduo por produção de fruta o valor de 0,33 , valor médio entre as taxas das culturas de laranja, maçã e pêssego, conforme Unal e Alibas (2007), pela falta de dados na literatura. A produção de caqui ocorre em Ribeirão Branco. 
Equação 1: produção anual de resíduos agrícolas da cultura de caqui (t/ano)

$$
\mathrm{R}_{\text {(caqui) }}=\text { produção anual }(\mathrm{t}) * 0,33
$$

Castanha de caju (Anacardium occidentalis): Nativo do Brasil, o fruto propriamente dito é a castanha e o pseudofruto é o caju, que contém $90 \%$ do peso da fruta como um todo. O manejo dos cajueiros necessita de podas de limpeza e formação (EMBRAPA, 2000). Como resíduo agrícola para estudo considerou-se como taxa de resíduo por produção de fruta 0,33 , valor médio entre as taxas das culturas de laranja, maçã e pêssego, conforme Unal e Alibas (2007). O caju é utilizado para consumo in natura, em sucos e doces. O processo industrial para fabricação de suco gera $40 \%$ em peso de bagaço sem valor comercial, geralmente sendo descartado (EMBRAPA, 2000). A produção de castanha gera, como resíduo, a casca $(67,5 \%$ do peso da castanha bruta) (MOHOD, JAIN e POWAR, 2011). Gadelha et al (2015) determinou PCI da castanha de caju (sem a extração do líquido da castanha de caju) em $5.377 \mathrm{kcal} / \mathrm{kg}$. Em Itapicuru, onde ocorre a produção de caju, vê-se a comercialização de frutas em época de safra às margens das rodovias próximas ao município (BR-110, BR-349). Não há processamento de suco na cidade.

Equação 2: produção anual de resíduos agrícolas da cultura de caju (t/ano)

$$
\mathrm{R}_{(\text {caju })}=\text { produção anual castanha } * 9 * 0,33
$$

Equação 3: produção anual de resíduos do processamento da castanha (t/ano)

$$
\mathrm{R}_{(\text {castanha) }}=\text { produção anual } * 0,675
$$

Equação 4: produção anual de resíduos do processamento do caju (pseudofruto) (t/ano)

$$
\mathrm{R}_{(\text {pseudofruto) }}=\text { produção anual castanha } * 9 * 0,4
$$

Coco-da-baía (Cocos nucifera): introduzido no Brasil em 1553, tem importância por seu valor nutricional, diversos usos no artesanato e valor cultural por sua forte associação com o nordeste do país. O fruto é composto pela água de coco (21,7\%), polpa (30\%), casca fibrosa $(33,3 \%)$ com PCI de $4.000 \mathrm{kcal} / \mathrm{kg}$ e casca lenhosa (que reveste a polpa) (15\%) com PCI de $5.500 \mathrm{kcal} / \mathrm{kg}$, tendo em média 1,2 kg de massa (MOURA \& LEITE, 2001; BANZON, 1980 apud GNESD, 2015). No manejo do coqueiral, é recomendado que as folhas e outros resíduos sejam triturados e mantidos como cobertura do solo a fim de manter a umidade do mesmo, não tendo assim resíduos agrícolas significativos para aproveitamento energético (EMBRAPA, 2001). Embora esta cultura ocorra em Itapicuru, as indústrias de aproveitamento de derivados 
de coco (coco ralado, leite de coco, água de coco) próximas situam-se em Sergipe. Os frutos são comercializados "verdes" para consumo da água de coco (região das praias do litoral norte da Bahia é mercado consumidor próximo), "maduros" para as indústrias de processamento de coco ou para mercado consumidor.

Tabela 5.4: Produção de resíduos do processamento do coco da baia.

\begin{tabular}{|l|c|c|c|}
\hline & \% em peso & Peso (t) & PCI (kcal/kg) \\
\hline Água de coco & 21,7 & & \\
\hline Polpa & 30 & & \\
\hline Casca fibrosa (externa) & 33,3 & 279,7 & 4.000 \\
\hline Casca lenhosa (interna) & 15 & 126 & 5.500 \\
\hline
\end{tabular}

Fonte: MOURA \& LEITE, 2001; BANZON, 1980 apud GNESD, 2015. Cálculos da autora.

Laranja (Citrus sinensis): fruta de origem asiática, a laranja tem como principal uso a fabricação de suco (puro ou com outras frutas e vegetais), um produto de exportação que atende mercados nos cinco continentes e pode ser congelado ou concentrado. No Brasil, além do suco, a fruta é consumida em doces e in natura devido ao seu valor nutricional e paladar agradável. Do peso da fruta, $50 \%$ é formado por casca, semente e fibras (AMARO, 1974 apud GNESD, 2015). Itapicuru possui importante produção de laranja, porém os frutos são enviados a fábricas localizadas prioritariamente em Sergipe pois não há fábrica no município embora já tenham surgido algumas intenções. Como resíduo da agricultura, temos o resultante de podas de formação. Segundo Unal e Alibas (2007), a taxa de resíduo por produção de fruta é 0,22. Embora o maior estado produtor de laranja no Brasil seja São Paulo, não há plantação significativa de laranjais em Ribeirão Branco.

Equação 5: produção anual de resíduos agrícolas da cultura de laranja (t/ano)

$$
\mathrm{R}_{(\text {laranja) }}=\text { produção anual } * 0,22
$$

Equação 6: produção anual de resíduos do processamento da laranja (suco) (t/ano)

$$
\mathrm{R}_{(\text {suco laranja) }}=\text { produção anual } * 0,5
$$

Maçã (Malus domestica): pseudofruto pomáceo da macieira, árvore cultivada há mais de 2.000 anos e introduzida no Brasil pelos colonizadores europeus. Mais de $80 \%$ da produção de maçã no país é consumida in natura e o restante utilizado em sucos, sidra, geleia, vinagre entre outros. O manejo do pomar prevê podas de raleio e de frutificação (EMBRAPA, 1994). Como a predominância é do consumo da fruta fresca, considera-se neste estudo apenas o resíduo 
agrícola. Conforme Unal e Alibas (2007), a taxa de resíduo por produção da maçã é de 0,47. Há macieiras apenas em Ribeirão Branco.

Equação 7: produção anual de resíduos agrícolas da cultura de maçã (t/ano)

$$
\mathrm{R}_{(\text {maçã })}=\text { produção anual } * 0,47
$$

Maracujá (Passiflora edulis): fruta de origem tropical das Américas, tem no Brasil seu principal produtor e consumidor mundial. Utilizada principalmente na fabricação de sucos, polpas e derivados, sendo também utilizada na fabricação de medicamentos fitoterápicos. $\mathrm{O}$ resíduo da lavoura consiste em partes aéreas da planta (folhas, ramos e gravinhas), que necessita de poda de formação e limpeza. O resíduo da indústria é constituído principalmente de cascas e sementes e representam $60 \%$ do peso da fruta. Esses resíduos com grandes quantidades de fibras solúveis e insolúveis, minerais, carboidrato e aminoácidos é descartado, embora possuam grande potencial para aproveitamento na alimentação animal, por exemplo (EMBRAPA, 1994; OLIVEIRA et al, 2002).

No caso da cultura do maracujá, que ocorre em Itapicuru, existem muitos estudos sobre aproveitamento de resíduos de processamento para consumo animal, humano, na indústria de cosméticos e farmacêutica. Neste caso, não foi considerado o resíduo agrícola desta cultura, por vários motivos técnicos, a saber (EMBRAPA, 2016):

- A escassez de dados sobre resíduos agrícolas do maracujazeiro;

- A existência de vários sistemas de produção vigentes no país - que dependem da região, condição sanitária e de cada produtor, variando muito em sua quantidade de resíduos;

○ A importância da cobertura morta de solo para para reter umidade, evitar erosão, evitar compactação do solo entre outros fatores; e

- A composição das podas verificadas no pomar (ramos, folhas e gravinhas).

Observa-se que as indústrias de suco se situam em Sergipe, de forma que a parte produtiva desta cultura se situa fora do município.

Equação 8: produção anual de resíduos do processamento do maracujá (suco) (t/ano)

$$
\mathrm{R}_{\text {(suco maracujá) }}=\text { produção anual * 0,6 }
$$


Pêssego (Prunus pérsica): fruta carnuda, doce e macia, com aroma delicado. Consumida in natura, como suco, em calda, geleia entre outros. Seu pomar requer poda de formação, de frutificação, de outono, de renovação e raleio. Os resíduos desse pomar são folhas e galhos principalmente. Da mesma forma que a maçã, a predominância é do consumo da fruta fresca, considera-se então, neste estudo, apenas o resíduo agrícola. Conforme Unal e Alibas (2007), a taxa de resíduo por produção de pêssego é de 0,30. Esta cultura está presente em Ribeirão Branco.

Equação 9: produção anual de resíduos agrícolas da cultura de pêssego (t/ano)

$$
\mathrm{R}_{(\text {pêssego })}=\text { produção anual } * 0,30
$$

\subsubsection{Culturas temporárias}

Cebola (Allium cepa): hortaliça condimentar muito utilizada no mundo, é largamente utilizada em preparações culinárias no país, que ainda depende da importação para abastecer o mercado interno. Consumida principalmente in natura, nas últimas décadas, o consumo deste vegetal processado tem crescido em pastas com alho e sal, purês, picles, desidratadas e minimamente processadas entre outros. Além dos atrativos gastronômicos, apresenta propriedades terapêuticas reconhecidas (EMBRAPA, 2002; VILELA et al, 2005). Resíduos do processamento são formados por cascas, camadas externas, raízes e talos. Os resíduos agrícolas são constituídos de partes aéreas que representam 16\% enquanto o bulbo (a cebola) representa 84\% em matéria seca da planta (MARROCOS et al, 2009). Em Ribeirão Branco há produção de cebolas.

Equação 10: produção anual de resíduos agrícolas da cultura de cebola (t/ano)

$$
\mathrm{R}_{(\text {cebola })}=\text { produção anual } * 16 / 84
$$

Mandioca (Manihot esculenta): no Brasil, dependendo da região, é também chamada de aipim ou macaxeira. Alimento consumido largamente no país, foi incorporado na gastronomia brasileira devido à influência dos indígenas. A parte de maior importância para a alimentação humana é a raiz. Folhas e caules possuem $144 \%$ a 257,1\% sobre o peso da raiz, segundo Bose \& Martins Filho (1984). Das partes aéreas é possível fazer forragem para uso como ração animal.

A mandioca pode ser consumida in natura, mas $60 \%$ aproximadamente da produção é destinada às casas de farinha. Na fecularia, amido e fécula são produzidos para utilização na alimentação humana e nas indústrias têxtil, alimentícia e de detergentes biodegradáveis 
(LAMAISON, 2009). Esses produtos da mandioca possuem importância cultural, nutricional e econômica, principalmente no norte e nordeste do país. Itapicuru possui produção de mandioca para alimentar casas de farinha.

Seu processamento gera sobre o peso da raiz in natura processada, $18 \%$ de cascas, $30 \%$ de manipueira (resíduo com alto teor de carboidratos), 24\% de crueira (fragmentos grosseiros da massa esfarelada de mandioca) e perdas na evaporação. O descarte da manipueira diretamente no solo ou em cursos d'água causa graves problemas ambientais por possuir alta demanda bioquímica de oxigênio (DBO), demanda química de oxigênio (DQO) e potencial tóxico pela presença de cianeto. Vários estudos são feitos para sua destinação, com aproveitamento como biofertilizantes, aproveitamento do potencial energético e como meio de cultura em diversos processos biotecnológicos, inclusive na produção de biossurfactantes (BOSE \& MARTINS FILHO, 1984; BARROS, 2007). A cada tonelada de raiz processada são gerados $0,33 \mathrm{~m}^{3}$ de resíduos (manipueira), sendo a produção de biogás a partir da digestão anaeróbica é, em média, $4,1 \mathrm{~m}^{3}$ a cada $\mathrm{m}^{3}$ de manipueira (FIORETTO et al, 2001; FEIDEN \& CEREDA, 2003)

Equação 11: produção anual de resíduos agrícolas da cultura de mandioca - folhas e caules (t/ano)

$$
\mathrm{R}_{(\text {mandioca })}=\text { produção anual } * 1,44
$$

Tabela 5.5: Produção de resíduos do processamento da mandioca.

\begin{tabular}{|l|c|c|}
\hline & & Resíduo \\
\hline Casca $^{\mathrm{a}}$ & $18 \%$ em peso & $4.230 \mathrm{t}$ \\
\hline Manipueira $^{\mathrm{b}}$ & $0,33 \mathrm{~m}^{3} / \mathrm{t}$ & $7.755 \mathrm{~m}^{3}$ \\
\hline
\end{tabular}

Fonte: a - BOSE \& MARTINS FILHO, 1984. B - FIORETTO et al, 2001. Cálculos da autora.

Melancia (Citrullus lanatus): planta de crescimento rasteiro originária do continente africano, é consumida principalmente in natura. Cascas podem ser usadas como alimentação para porcos, patos e galinhas. A fruta tem $92 \%$ de água em sua composição. Pertence à família das Curcubitaceae, assim como pepino, abóbora e melão entre outros. Os resíduos da lavoura são formados por folhas, raízes e caules (EMBRAPA, 2009). Santana-Méridas et al (2012) utilizam em seu estudo a taxa de 0,45 na produção de resíduos da cultura por produção de frutos de melão. Essa mesma taxa foi utilizada na avaliação teórica dos resíduos da cultura de melancia no município de Itapicuru. 
Equação 12: produção anual de resíduos agrícolas da cultura de melancia (t/ano)

$$
\mathrm{R}_{(\text {melancia })}=\text { produção anual } * 0,45
$$

Melão (Cucumis melo): existem vários tipos plantados no país, e suas características como cor, tamanho dependem do cultivar. Fruta de sabor característico, refrescante devido ao alto teor de água, é utilizada principalmente para consumo in natura. Os resíduos da lavoura são formados por folhas, raízes e caules (EMBRAPA, 2008). Santana-Méridas et al (2012) utilizam em seu estudo a taxa de 0,45 na produção de resíduos da cultura por produção de frutos. Melão, da mesma forma que a melancia, é cultivada em Itapicuru.

Equação 13: produção anual de resíduos agrícolas da cultura de melão (t/ano)

$$
\mathrm{R}_{(\text {melão) }}=\text { produção anual } * 0,45
$$

Milho (Zea mays): cereal de grande importância para alimentação humana ou como ração animal, tem como principal resíduo de sua lavoura a palha, gerada na proporção de 1:1 em massa. Aqui assumiu-se que $60 \%$ dessa palha pode ser aproveitada como resíduo, sendo que o restante é utilizado para cobertura do solo (KIM \& DALE, 2004; SHEEHAN et al, 2002 apud GNESD, 2015). O processo de debulha gera 1 tonelada de grãos a cada $1.429 \mathrm{~kg}$ de espigas (FGV, 1991). Embora com produção em ambas as cidades estudadas, não há processo de beneficiamento de milho em nenhum dos dois municípios.

Equação 14: produção anual de resíduos agrícolas da cultura de milho (t/ano)

$$
\mathrm{R}_{(\text {milho) }}=\text { produção anual } * 0,60
$$

Equação 19: produção anual de resíduos - espigas (t/ano)

$$
\mathrm{R}_{\text {(espigas) }}=\text { produção anual } * 1,429
$$

Tomate (Solanum lycopersicum): hortaliça das mais consumidas no mundo, esse fruto originalmente latino-americano pode ser consumido in natura, suco, molhos entre outros. A lavoura do tomate gera uma taxa de 0,30 de resíduo (caules e folhas) por produto (UNAL \& ALIBAS, 2007). Na industrialização, o resíduo de tomate na produção de sucos ou polpa gera em torno de $8,1 \%$ do peso do fruto fresco, composto de sementes e casca, com pequena quantidade de polpa. Essa composição é variável e depende do produto final. O manejo incorreto desse resíduo pode trazer agravos ao meio ambiente (PEREIRA et al, 2017). O destino preferencial da produção de tomate (atomatados industriais ou in natura) depende do cultivar do tomate. Embora com grande produção em Ribeirão Branco, não há processamento industrial de tomate no município. Assim considera-se nesse estudo apenas o resíduo agrícola da produção. 
Equação 15: produção anual de resíduos agrícolas da cultura de tomate (t/ano)

$$
\mathrm{R}_{\text {(tomate) }}=\text { produção anual } * 0,30
$$

A partir destas informações levantadas, foi elaborada a tabela 5.6, com a quantidade de resíduos da produção agrícola (lavoura e processamento) calculada para os municípios estudados.

Tabela 5.6: Produção calculada de resíduos da produção agícola municipal de Itapicuru e Ribeirão Branco conforme dados de 2017.

\begin{tabular}{|c|c|c|}
\hline \multirow[b]{2}{*}{ Cultura permanente } & \multicolumn{2}{|c|}{ Resíduos da produção agrícola e processamento (t/ano) } \\
\hline & Itapicuru & Ribeirão Branco \\
\hline Castanha de caju: casca & 221 & - \\
\hline Bagaço de caju & 1.177 & - \\
\hline Caju & 971 & - \\
\hline Caqui & - & 462 \\
\hline Coco-da-baía: casca fibrosa & 298 & - \\
\hline Coco-da-baía: casca lenhosa & 126 & - \\
\hline Laranja & 13.200 & - \\
\hline Laranja: processamento & 30.000 & \\
\hline Maçã & - & 470 \\
\hline Maracujá: processamento & 1.949 & - \\
\hline Pêssego & - & 300 \\
\hline \multicolumn{3}{|l|}{ Cultura temporária } \\
\hline Cebola & - & 1.300 \\
\hline Mandioca & 33.840 & - \\
\hline Mandioca: casca & 4.230 & - \\
\hline Mandioca: manipueira & 7.755 & - \\
\hline Mandioca: crueira & 5.640 & \\
\hline Melancia & 1.800 & - \\
\hline Melão & 495 & - \\
\hline Milho & 20.920 & 30.240 \\
\hline Milho: espigas & 49.823 & 72.022 \\
\hline Tomate & - & 31.547 \\
\hline
\end{tabular}

Fonte: Cálculos elaborados pela autora. 


\section{3 RESÍDUOS DA SILVICULTURA}

Nos municípios estudados, e de forma mais intensa em Ribeirão Branco, a silvicultura ocupa áreas produtivas representativas. $\mathrm{O}$ plantio de pinus é fonte de vários produtos como madeira para fibras, madeira serrada e resina entre outros. A área destinada à cultura de pinus é explorada em muitas propriedades, segundo informações coletadas em visita de campo, com a extração de resina, matéria-prima que oferece elevada remuneração por sua aplicação na indústria de cosméticos, pneus, tintas, goma de mascar entre outros devido à sua composição (breu e terebentina) (EMPRAPA, 2014).

A produção de madeira em toras, segundo informações de moradores em Ribeirão Branco, é destinada em grande parte a indústrias de papel e celulose. Existem unidades de grandes grupos como a Klabin, Cia Suzano, Fibria em cidades próximas. Verificou-se grande movimentação de carretas com toras nas rodovias que dão acesso ao município (SP-270, BR373 e SP-252). Assim sendo, considerou-se para a estimativa de resíduo apenas o deixado no campo após o corte - 15\%. O PCI do resíduo é de $2.000 \mathrm{kcal} / \mathrm{kg}$ e, ainda segundo o Atlas de Bioenergia do Brasil, $1 \mathrm{~m}^{3}$ de madeira corresponde a 0,68t (COELHO et al, 2009).

Equação 16: produção anual de resíduos de silvicultura (t/ano)

$$
\mathrm{R}_{\text {(silvicultura) }}=\operatorname{produção~} \operatorname{anual}\left(\mathrm{m}^{3}\right) * 0,68 * 0,15
$$

Tabela 5.7: Produção calculada de resíduos da Silvicultura em Ribeirão Branco conforme dados de 2017.

\begin{tabular}{|c|c|}
\hline & Resíduos da produção (t/ano) \\
\hline Resíduos de madeira & 9.097 \\
\hline Fonte: Cálculos elaborados pela autora.
\end{tabular}

\section{4 PRODUÇÃO PECUÁRIA}

Introduzida no nordeste brasileiro no Sec. XVI, a pecuária brasileira começou nas regiões canavieiras da Bahia, servindo como instrumento de colonização do interior. Devido à forte seca, a atividade migrou para a região das Minas Gerais, chegando até os Pampas Gaúchos (PRADO JR, 2017). Setor de grande importância para economia brasileira, denota criação de rebanho para diversos fins: carne, leite, lã, ovos entre outros.

A tabela 5.8 apresenta a produção pecuária de cada um dos municípios selecionados em 2017, segundo o IBGE (2019). 
Tabela 5.8: Produção pecuária municipal de Itapicuru e Ribeirão Branco. Dados de 2017.

\begin{tabular}{|l|c|c|}
\hline Rebanho & $\begin{array}{c}\text { Itapicuru } \\
\left(\mathrm{N}^{0} . \text { de cabeças }\right)\end{array}$ & $\begin{array}{c}\text { Ribeirão Branco } \\
\left(\mathrm{N}^{\mathrm{o}} \text {. de cabeças }\right)\end{array}$ \\
\hline Bovinos - total & 21.961 & 13.926 \\
\hline Bovinos - vacas ordenhadas & 1.645 & 171 \\
\hline Equinos & 1.478 & 3.600 \\
\hline Galináceos & 39.500 & 18.000 \\
\hline Galináceos - poedeiras & 17.400 & 9.000 \\
\hline Ovinos & 6.605 & 500 \\
\hline Suínos & 1.478 & 960 \\
\hline
\end{tabular}

Fonte: IBGE (2019).

Em se tratando de criação animal, ambos municípios apresentam diversos plantéis, mas para o aproveitamento energético se faz necessário que os dejetos sejam de fácil coleta, o que ocorre principalmente com suínos e aves. Itapicuru possui quantidade significativa de aves para abate e poedeiras também. Ribeirão Branco também tem como destaque a criação de aves.

\section{5 RESÍDUOS DA PECUÁRIA}

Dejetos de animais são um desafio para a produção intensiva e seu manejo adequado se faz necessário devido aos riscos de contaminação de águas superficiais e subterrâneas por nitrito, fósforo e outros elementos minerais ou orgânico, e do ar por $\mathrm{NH}_{3}, \mathrm{CO}_{2}, \mathrm{H}_{2} \mathrm{~S}$ entre outros.

Contudo, esse material pode ser aproveitado como biomassa para geração de energia através da biodigestão anaeróbica. Nesse processo, um conjunto de microrganismos degrada a matéria orgânica formando o biogás, composto por metano - $\mathrm{CH}_{4}(50$ a $70 \%)$ e $\mathrm{CO}_{2}$. A coleta desse gás possibilita seu uso como combustível para geração de calor ou energia elétrica, contribuindo para o uso de energia renovável e trazendo sustentabilidade para a criação (KUNZ \& OLIVEIRA, 2006).

A estimativa de geração de resíduos animais baseou-se em literatura específica para cada espécie, conforme abaixo:

Bovinos de corte e matrizes: $20 \mathrm{~kg}$ de estrume por dia por cabeça (MOTTA, 1986; MANSO, 2007).

Equação 17: produção anual de resíduos da criação de bovinos de corte e matrizes (t/ano)

$$
\mathrm{R}_{\text {(bovino) }}=\left(\mathrm{n}^{\text {o }} \text { cabeças } * 20 * 365\right) / 1000
$$


Bovinos (leiteiro): literatura indica entre 35 e $55 \mathrm{~kg}$ de estrume por dia. Usou-se valor médio de $45 \mathrm{~kg}$ por dia por cabeça (POHLMANN, 2000).

Equação 18: produção anual de resíduos da criação de vacas leiteiras (t/ano)

$$
\mathrm{R}_{\text {(leiteiro) }}=\left(\mathrm{n}^{\mathrm{o}} \text { cabeças } * 45 * 365\right) / 1000
$$

Equinos: Barrera (1993) cita que a produção diária de esterco de equinos é de 10 kg/animal.

Equação 19: produção anual de resíduos da criação de equinos (t/ano)

$$
\mathrm{R}_{\text {(equino) }}=\left(\mathrm{n}^{\mathrm{o}} \text { cabeças } * 10 * 365\right) / 1000
$$

Galináceos: na criação de frangos de corte, os excrementos, penas, restos de comida se misturam ao material (“cama de frango") utilizado como forração do galinheiro, normalmente maravalha (aparas de madeira). Neste caso, Santos (2001) sugere 0,18 kg por cabeça ao dia adicionando $1,37 \mathrm{~kg}$ de matéria seca (cama) por cabeça.

Equação 20: produção anual de resíduos da criação frangos de corte (t/ano)

$$
\mathrm{R}_{(\text {frango })}=\left[\left(\mathrm{n}^{\mathrm{o}} \text { cabeças } * 0,18 * 365\right)+\left(1,37 * \mathrm{n}^{\mathrm{o}} \text { cabeças }\right)\right] / 1000
$$

Galináceos (postura): para criação de galinhas poedeiras, elas são mantidas em gaiolas suspensas, sendo que os dejetos se encontram misturados a penas, restos de ovos quebrados entre outros. Assim, considerou-se $0,12 \mathrm{~kg}$ de resíduos por cabeça ao dia (EL BOUSHY \& VAN DER POEL, 1994).

Equação 21: produção anual de resíduos da criação poedeiras (t/ano)

$$
\mathrm{R}_{\text {(poedeiras) }}=\left(\mathrm{n}^{\mathrm{o}} \text { cabeças } * 0,12 * 365\right) / 1000
$$

Ovinos: segundo Embrapa (2007), ovinos adultos produzem até $1500 \mathrm{~kg}$ de esterco por ano. Como há indivíduos em vários estágios de criação, usa-se aqui $750 \mathrm{~kg}$ de esterco por ano por cabeça.

Equação 22: produção anual de resíduos da criação de ovinos (t/ano)

$$
\mathrm{R}_{\text {(ovinos) }}=\left(\mathrm{n}^{\text {o }} \text { cabeças } * 750\right) / 1000
$$

Suínos: há variação entre os estágios de criação, sendo usados aqui 2,25 kg de estrume por dia por cabeça (MOTTA, 1986; MANSO, 2007).

Equação 23: produção anual de resíduos da criação de suínos (t/ano) 


$$
\mathrm{R}_{\text {(suínos) }}=\left(\mathrm{n}^{\text {o }} \text { cabeças } * 2,25 * 365\right) / 1000
$$

Bubalinos não foram considerados por seu pequeno plantel. Codornas também não entraram no cálculo por sua criação não ser significativa para nenhum dos municípios.

A partir dos índices acima e com a produção de pecuária levantadas nas visitas de campo, foram calculadas as quantidades de dejetos de animais calculada para os municípios estudados, conforme ilustrado na Tabela 5.9.

Tabela 5.9: Produção calculada de dejetos da produção animal municipal de Itapicuru e Ribeirão Branco conforme dados de 2017.

\begin{tabular}{|l|c|c|}
\hline & \multicolumn{2}{|c|}{ Dejetos da produção animal (t/ano) } \\
\hline Rebanho & Itapicuru & Ribeirão Branco \\
\hline Bovinos (corte e matrizes) & 160.315 & 101.660 \\
\hline Bovinos (leiteiro) & 27.019 & 2.809 \\
\hline Equinos & 5.395 & 13.140 \\
\hline Galináceos & 2.649 & 1.207 \\
\hline Galináceos (postura) & 762 & 394 \\
\hline Ovinos & 4.954 & 375 \\
\hline Suínos & 1.214 & 788 \\
\hline Total resíduos & 202.308 & 120.373 \\
\hline
\end{tabular}

Fonte: Cálculos elaborados pela autora.

Uma situação que merece destaque é a crescente importância sobre o bem-estar animal para os plantéis utilizados na alimentação humana. Desde que a União Europeia, em 2009, reconheceu que animais de fazenda são senscientes - capazes de sentir emoções como medo e felicidade, o mercado consumidor tem voltado sua atenção para o sofrimento e estresse presentes no confinamento desses animais, com surgimento de um movimento crescente para modificação do manejo destes plantéis, que possivelmente impactará na utilização de seus dejetos como fonte de biomassa para aproveitamento energético (WORLDANIMALPROTECTION, 2020).

\section{6 RESÍDUOS URBANOS MUNICIPAIS}

O aproveitamento energético de resíduos urbanos vem sendo objeto de atenção crescente no país e no mundo, pela sinergia existente com o saneamento básico. Considera-se resíduo urbano todo rejeito da atividade humana. Este pode ser líquido (esgoto) ou sólido (lixo), e sua destinação e aproveitamento deve obedecer à legislação existente. 
No caso de resíduos sólidos urbanos (RSU), o tema ganha maior importância a partir da publicação da Lei 12.305/2010 que estabelece a Política Nacional de Resíduos Sólidos (PNRS). Para as estimativas de aproveitamento energético, a disponibilidade de RSU em cada município foi avaliada a partir de estimativas de produção de resíduo per capita, considerando que todo o resíduo gerado seja coletado e destinado ao aproveitamento energético. A geração de resíduo per capita de acordo com a população das cidades, é apresentada na tabela 5.10.

Nesta tese, a estimativa do resíduo sólido disponível nos municípios selecionados foi realizada em função do número de habitantes de cada município; assim, utilizou-se a taxa de $0,7 \mathrm{~kg} /$ per capita por dia para o município de Ribeirão Branco e $0,8 \mathrm{~kg} /$ per capita por dia para Itapicuru. A fração orgânica usada para a estimativa foi de 51,4\% conforme a média nacional (ABRELPE, 2011).

Tabela 5.10: Geração de resíduo sólido urbano per capita de acordo com a população.

\begin{tabular}{|l|c|}
\hline \multicolumn{1}{|c|}{ População (hab) } & $\begin{array}{c}\text { Geração de resíduo sólido } \\
\text { (kg/hab/dia) }\end{array}$ \\
\hline Municípios até 25.000 & 0,7 \\
\hline Municípios entre 25.001 a 100.000 & 0,8 \\
\hline Municípios entre 100.001 a 500.000 & 0,9 \\
\hline Municípios acima de 500.001 & 1,1 \\
\hline
\end{tabular}

Fonte: CETESB (2019).

A estimativa da produção de esgoto (resíduo líquido) considerou 160 L per capita ao dia, conforme adotado por Coelho e Garcilasso (2019), já que a média oscila entre130 a $170 \mathrm{~L}$ per capita por dia (SAAE, 2013).

A tabela 5.11 apresenta de forma resumida dados já apresentados no capítulo anterior, utilizados para os cálculos da geração de resíduos sólidos e líquidos dos municípios, bem como a estimativa da geração de resíduos municipais.

As taxas utilizadas estão disponibilizadas na literatura. Apresenta-se então, dos valores gerados de resíduo sólido e esgoto, o que é efetivamente coletado. Em Ribeirão Branco, quase todo resíduo sólido gerado é coletado e apenas metade do esgoto é coletado e tratado. Em Itapicuru, próximo de $12 \%$ do resíduo gerado e $88 \%$ do esgoto não são coletados. Além da impossibilidade do aproveitamento energético de grande quantidade de subprodutos da vida humana, esse material não coletado provavelmente tem destino incorreto, ocasionando danos ao meio ambiente. 
Tabela 5.11: Estimativa de geração de resíduo sólido e esgoto nos municípios.

\begin{tabular}{|l|c|c|}
\hline & Itapicuru & Ribeirão Branco \\
\hline População (censo 2010) - hab. & 32.261 & 18.269 \\
\hline Taxa coleta de lixo (\%) & 87,16 & 98,30 \\
\hline Taxa coleta de esgoto (\%) & 11,4 & 51,2 \\
\hline Resíduo sólido urbano (t/dia) & 25,81 & 12,79 \\
\hline Total coletado (t/dia) & 22,45 & 12,57 \\
\hline Total orgânico coletado (t/dia) & 11,54 & 6,46 \\
\hline Esgoto produzido (l/dia) & 5.161 .760 & 2.923 .040 \\
\hline Esgoto coletado (1/dia) & 588.441 & 1.496 .597 \\
\hline
\end{tabular}

Fonte: IBGE (2019) com dados do Censo 2010. Cálculos obtidos pela autora.

\section{7 POTENCIAL DE GERAÇÃO DE ENERGIA}

A partir das estimativas de quantidades de resíduos disponíveis, o potencial de geração de energia foi avaliado, considerando as melhores tecnologias aplicáveis a cada tipo de biomassa, de acordo com o que foi apresentado em capítulo anterior, onde discutiu-se vantagens, desvantagens e viabilidade do uso da combustão direta, gaseificação e digestão anaeróbica.

Assim, esta seção apresenta a estimativa de geração de energia a partir da biomassa residual, considerando os resíduos que efetivamente permanecem nos municípios, de acordo com levantamento feito em visita de campo nas duas regiões.

- Itapicuru: considera-se todo resíduo agrícola, o resíduo do processamento da castanha, resíduos da produção de fécula e farinha de mandioca, resíduo dos animais criados em sistema de confinamento (aves e suínos) e resíduos municipais coletados (sólidos e líquidos). Aqui, boa parte da produção agrícola destina-se a processamento agroindustrial realizado em cidades próximas, de forma que parte do potencial de geração de energia é "exportado". Esse tema será retomado em discussão futura.

- Ribeirão Branco: considera-se todo resíduo agrícola, o resíduo da silvicultura que fica no campo (extração da madeira), resíduo dos animais criados em sistema de confinamento (aves e suínos) e resíduos municipais coletados (sólidos e líquidos). A maior parte da produção agrícola deste município é destinada ao consumo in natura (frutas de mesa e vegetais). 
Para cada tipo de resíduo de biomassa, foi considerada a tecnologia mais adequada para aproveitamento energético de pequeno porte, como analisado a seguir. A figura 5.1 mostra de forma simplificada as possibilidades de aproveitamento energético para cada tipo de biomassa residual.

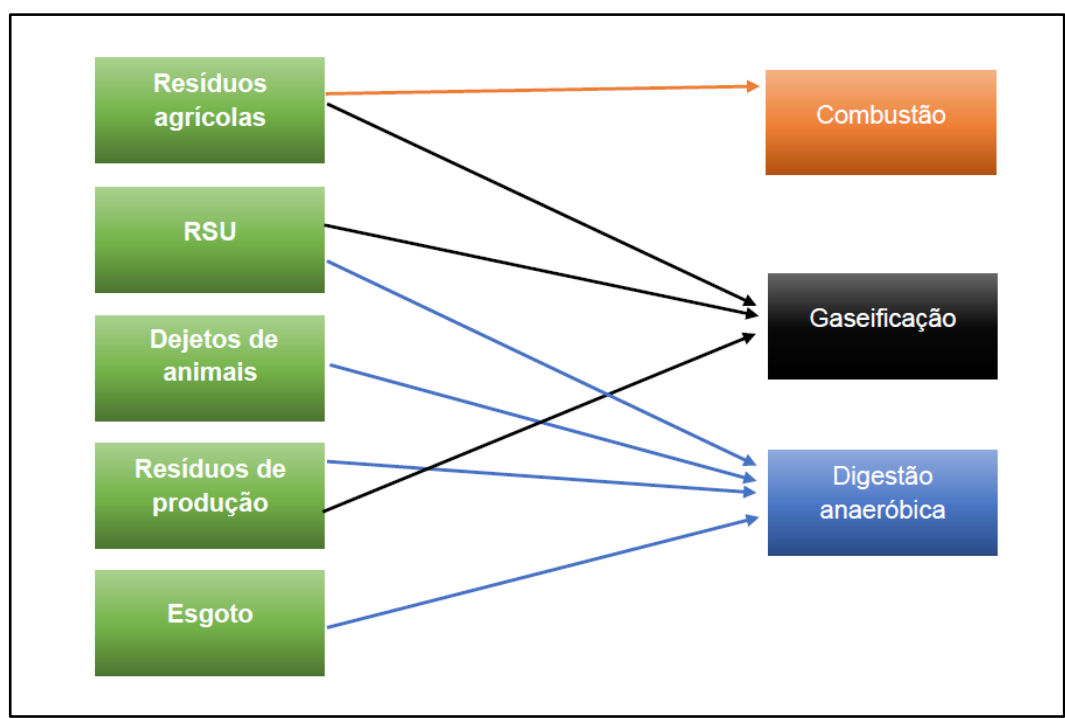

Figura 5.1: Possibilidades de aproveitamento energético para biomassa residual. Fonte: elaborado pela autora.

\section{7.1 Combustão direta em sistemas de pequeno porte}

Para esta tecnologia, que foi detalhada na seção 3.5.1, calculou-se o potencial para os resíduos que teriam melhor aproveitamento energético (menor teor de umidade) e que ficam no campo, ou sejam:

- cascas da castanha de caju,

- resíduos de silvicultura (manejo) e

- resíduos agrícolas de poda de pomares:

○ laranja, em Itapicuru

○ caqui, maçã e pêssego em Ribeirão Branco.

Para cada um deles, foi considerado o PCI (poder calorifico inferior - calor total liberado pela combustão estando toda a água gerada no estado gasosos) encontrado na literatura. Para resíduos agrícolas da poda de pomares, considerou-se PCI de $4.300 \mathrm{kcal} / \mathrm{kg}$, conforme Cortez (2011).

Considera-se o sistema operando durante $8 \mathrm{~h}$ dia, ano todo para silvicultura e as podas de manutenção dos pomares e 6 meses ao ano para a castanha, o que corresponde ao período de 
safra média no ano (julho a dezembro), sendo os resíduos gerados pela produção anual calculada

Foi adotado o sistema convencional de ciclo a vapor, adotando o rendimento termodinâmico de $15 \%$ (para sistemas a vapor de pequeno porte, com potência instalada entre 200kW e 10 MW (VELAZQUEZ et al, 2010), conforme a equação 24.

$$
\begin{gathered}
\text { Equação 24: Potencial de geração de energia (MW) } \\
\mathrm{P}_{(\text {combustão) }}=[\text { resíduo }(\mathrm{t}) * \mathrm{PCI}(\mathrm{kcal} / \mathrm{kg}) * 0,15] /(860 \times \mathrm{H})
\end{gathered}
$$

Onde:

$\mathrm{H}=\mathrm{n}^{\mathrm{o}}$ de horas de operação (1.440h para a castanha e 2.920h para silvicultura e poda de pomares).

$\mathrm{PCI}=$ poder calorifico interior, dado pela tabela 5.12

A taxa de conversão de kcal/kg para $\mathrm{kWh} / \mathrm{kg}$ é obtida pela divisão por 860 .

Tabela 5.12: Estimativa de capacidade instalada para geração de energia por combustão direta (MW)

\begin{tabular}{|l|c|c|c|c|}
\hline & $\begin{array}{c}\text { PCI (kcal / } \\
\mathrm{kg})\end{array}$ & $\begin{array}{c}\text { Resíduos } \\
\text { (t/ano) }\end{array}$ & $\begin{array}{c}\text { Itapicuru } \\
(\mathrm{MW})\end{array}$ & $\begin{array}{c}\text { Ribeirão } \\
\text { Branco (MW) }\end{array}$ \\
\hline $\begin{array}{l}\text { Processamento da } \\
\text { castanha: casca }\end{array}$ & 5.377 & 221 & 0,145 & - \\
\hline $\begin{array}{l}\text { Silvicultura (campo) } \\
\text { Poda de pomares - caju e }\end{array}$ & 4.300 & 14.171 & 3,640 & - \\
\hline $\begin{array}{l}\text { laranja } \\
\text { Poda de pomares - caqui, }\end{array}$ & 4.300 & 1.232 & - & 0,316 \\
\hline maçã e pêssego & & 9.097 & - & 1,403 \\
\hline Total & & & 3,785 & \\
\hline
\end{tabular}

Fonte: Cálculos elaborados pela autora.

Os resultados da tabela 5.12 confirmam a possibilidade de uso de sistemas a vapor de pequeno porte para o aproveitamento energético de resíduos de biomassa sólida, disponíveis no país comercialmente, como discutido na seção 3.5.1. 


\section{7.2 Biodigestão anaeróbica}

Conforme discutido na seção 3.5.2, esta tecnologia é recomendada para aproveitamento de resíduos sólidos e efluentes de origem animal, doméstico e comercial (orgânicos).

A tabela 5.13 resume os valores para conversão energética de dejetos de diferentes criações.

Tabela 5.13: Conversão energética para dejetos de diferentes origens

\begin{tabular}{|l|c|c|}
\hline Origem do esterco & Produção biogás (kg/ kg esterco) & Concentração de metano (\%) \\
\hline Aves - corte & 0,2295 & 60 \\
\hline Aves - postura & 0,0550 & 60 \\
\hline Bovinos & 0,0370 & 60 \\
\hline Equinos & 0,0480 & 60 \\
\hline Suínos & 0,0620 & 66 \\
\hline
\end{tabular}

Fonte: MOTTA, 1986

A quantidade de metano contida no biogás gerado pela decomposição do esterco produzido é calculada de acordo com a equação 25. Considerou-se o volume específico do metano (VE) igual a $0,670 \mathrm{~kg} \mathrm{CH}_{4} / \mathrm{m}^{3} \mathrm{CH}_{4}$.

Equação 25: metano obtido da digestão anaeróbica de diferentes criações ( $\left.\mathrm{m}^{3} \mathrm{CH}_{4} / \mathrm{ano}\right)$

$\mathrm{M}_{(\text {animal })}=[$ resíduo $(\mathrm{kg} / \mathrm{ano}) *$ produção biogás $(\mathrm{kg} / \mathrm{kg}$ esterco $) *$ conc. Metano $] / \mathrm{VE}$

$\mathrm{O}$ esgoto coletado e tratado pode gerar biogás, que contém $\mathrm{CH}_{4}$ e $\mathrm{CO}_{2}$ principalmente, se o lodo for submetido ao tratamento anaeróbico. A quantidade de esgoto diária e taxas de coleta estão na tabela 5.11. Considerou-se que todo esgoto coletado seja tratado, embora essa não seja a realidade. Para o cálculo de geração de metano, foi utilizada a equação:

Equação 26: metano obtido da digestão anaeróbica de lodo resultante de esgoto ( $\mathrm{m}^{3} \mathrm{CH}_{4} / \mathrm{h}$ ano). Fonte: Coelho \& Garcilasso, 2019.

$$
\mathrm{M}_{(\text {esgoto })}=[\text { efluente coletado (1/dia) } * 0,001 * 365 * \text { DBOefl } * \mu * 0,25] / 0,72
$$


Onde:

365 = número de dias por ano

$0,001=$ fator de conversão de 1 para $\mathrm{m} 3$

$\mathrm{DBO}_{5}=$ taxa de geração de demanda bioquímica de oxigênio. Conforme utilizado no Atlas de Bioenergia do Brasil (COELHO et al, 2009), para o cálculo considerou-se 0,3 $\mathrm{kgDBO} 5 / \mathrm{m}^{3}$ de esgoto.

$\mu=$ eficiência do biodigestor, estimada em 50\% conforme Coelho et al (2009).

0,25 = considerado como máximo fator de emissão de metano $\left(\mathrm{tCH}_{4}\right.$ por tonelada de $\mathrm{DBO}$ removida), conforme valor sugerido pelo Intergovernamental Panel on Climate Change (IPCC) e utilizado por Coelho et al (2009).

$0,72=$ densidade do metano $\left(\mathrm{kg} \mathrm{CH}_{4} / \mathrm{m}^{3} \mathrm{CH}_{4}\right)$

A fração orgânica do resíduo sólido municipal (doméstico, comercial e agrícola) quando devidamente disposto, pode gerar biogás. Neste estudo, para o cálculo do potencial de metano gerado pela digestão anaeróbica deste resíduo considerou-se que a fração coletada do RSU seguiu para aterro. A metodologia do cálculo está baseada em recomendação do IPCC e utilizado no Atlas de Bioenergia do Brasil (COELHO et al, 2009), segundo a equação 27.

Equação 27: metano obtido da digestão anaeróbica de resíduo sólido municipal coletado $\left(\mathrm{m}^{3}\right.$ $\left.\mathrm{CH}_{4} / \mathrm{ano}\right)$. Fonte: Coelho \& Garcilasso, 2019.

$$
\mathrm{M}_{(\text {resíduo sólido) }}=[\mathrm{V} \text { lixo } * 365 * \mathrm{FCM} * \mathrm{COD} * \mathrm{CODf} * \mathrm{~F} *(16 / 12)] / \text { 0,00072 }
$$

Onde:

V lixo = volume de resíduos sólidos coletados em $\mathrm{t} / \mathrm{dia}$ (considerando que todo resíduo coletado fosse disposto em aterro sanitário)

365 = número de dias por ano

FCM = fator de correção de metano, recomendado pelo IPCC (1996) de acordo com a profundidade de disposição do resíduo. Neste caso, utilizou-se $60 \%$ que é o valor para locais sem essa classificação. 
COD = carbono orgânico degradável, adimensional, considerado $12 \%$ conforme sugestão do IPCC (1996), valor que não considera a composição de resíduos pois esses dados não são conhecidos nos municípios estudados.

CODf $=$ valor adimensional que representa a taxa de COD que efetivamente degrada. $\mathrm{A}$ recomendação do IPCC (2006) é de 50\%.

$\mathrm{F}=$ fração de metano no biogás do aterro, recomendada pelo IPCC (1996) em 50\%

$16 / 12$ = conversão de carbono em metano

$0,00072=$ densidade do metano $\left(\mathrm{t} \mathrm{CH}_{4} / \mathrm{m}^{3} \mathrm{CH}_{4}\right)$

Assim, o potencial estimado de geração de metano nas cidades estudadas, conforme a fonte, estão na tabela 5.14 .

Tabela 5.14: Potencial de geração de metano através da digestão anaeróbica proveniente de diferentes fontes em cada cidade estudada $\left(\mathrm{m}^{3} \mathrm{CH}_{4} / \mathrm{h}\right.$ ano)

\begin{tabular}{|l|c|c|}
\hline & Itapicuru & Ribeirão Branco \\
\hline Resíduo produção animal (aves e suínos) & 74,9 & 36,04 \\
\hline Esgoto coletado & 1,23 & 3,24 \\
\hline Resíduos sólidos & 16,06 & 8,97 \\
\hline Resíduo agrícola (manipueira) & 2,18 & -- \\
\hline Total do potencial de geração de metano & 98,87 & 48,25 \\
\hline
\end{tabular}

Fonte: cálculos obtidos pela autora

O metano gerado pode ser aproveitado para geração de energia elétrica, aquecimento, transporte entre outros. A potência disponível pela utilização desse biogás gerado pela digestão anaeróbia de resíduos é calculada conforme equação 28.

Equação 28: potência disponível obtida com biogás gerado na digestão anaeróbica de resíduo nos municípios ( $\left.\mathrm{m}^{3} \mathrm{CH}_{4} / \mathrm{ano}\right)$. Fonte: Coelho \& Garcilasso, 2019.

$$
\mathrm{P}=(\mathrm{Q} * \mathrm{PCI} * \mathrm{n}) / 860
$$

Onde:

$\mathrm{P}=$ potência disponível $(\mathrm{kW})$

$\mathrm{Q}=$ vazão de biogás $(\mathrm{m} 3 / \mathrm{h})$ 
PCI (biogás) = Poder Calorífico Inferior do biogás $=5.500 \mathrm{kcal} / \mathrm{Nm} 3 \mathrm{CH} 4$

$\eta=$ eficiência de motores ciclo Otto operando a biogás $=28 \%=0,28$

860 = fator de conversão de $\mathrm{kcal} / \mathrm{h}$ para $\mathrm{kW}$

A tabela 5.15 apresenta a potência disponível para os dois municípios estudados, considerando a utilização do biogás gerado pela digestão anaeróbica de dejetos de animais confinados (aves e suínos), resíduo de produção (manipueira em Itapicuru), resíduos sólidos municipais coletados e do esgoto coletado.

Tabela 5.15: Potência disponível (MW) pelo biogás gerado através da digestão anaeróbica proveniente de diferentes fontes em cada cidade estudada (MW)

\begin{tabular}{|l|c|c|}
\hline Tipo de resíduo & $\begin{array}{c}\text { Potência disponível } \\
\text { ITAPICURU }\end{array}$ & $\begin{array}{c}\text { Potência disponível } \\
\text { RIBEIRAO BRANCO }\end{array}$ \\
\hline Resíduo animal & 0,221 & 0,106 \\
\hline RSU coletado & 0,058 & 0,032 \\
\hline Esgoto coletado & 0,003 & 0,009 \\
\hline Resíduo processamento & 0,007 & -- \\
\hline Total & 0,289 & 0,147 \\
\hline
\end{tabular}

Fonte: cálculos obtidos pela autora

Os resultados acima confirmam a possibilidade de uso do processo de biodigestão anaeróbia para os resíduos orgânicos. Os potenciais calculados podem ser obtidos com o uso de motores existentes comercialmente no país, como discutido na seção 3.5.2.

\section{7.3 Gaseificação de pequeno/médio porte}

A gaseificação consiste num processo termoquímico que converte matéria prima sólida ou líquida num gás com características combustíveis (gás de síntese), através de oxidação parcial a temperaturas intermediárias. O gás produzido pela gaseificação da biomassa, com composição variável de monóxido de carbono e hidrogênio, pode ser utilizado em motores alternativos de combustão interna, turbinas a gás para geração de energia mecânica e eletricidade, geração de calor entre outros (LORA et al, 2008). Na seção 3.5.3 foram discutidos os diferentes tipos de gaseificadores e o seu uso em cada caso, dependendo da disponibilidade de resíduo. 
Os cálculos de potencial de aproveitamento energético com sistemas de gaseificação foram baseados em algumas premissas, conforme informações obtidas em simulação com fabricante de equipamento no país (CARBOGÁS, 2019), considerando o gaseificador de leito fluidizado de sua fabricação:

- Resíduos agrícolas são tratados como um todo e têm um PCI em base seca similar à média de material orgânico, aproximadamente $4.500 \mathrm{kcal} / \mathrm{kg}$; entrando no processo com umidade de $15 \%$, tem-se um PCI médio de $3.825 \mathrm{kcal} / \mathrm{kg}$.

- Resíduo sólido urbano (RSU) coletado é integralmente processado, tanto a fração orgânica quanto plásticos, borrachas, espumas entre outros são gaseificados. Os cálculos consideraram o total de RSU coletado, deduzidas as frações percentuais de metais, vidro e inertes (outros), ou seja, 22\% (ABRELPE, 2011). Este RSU possui em média, 50\% de umidade e PCI médio de $1.800 \mathrm{kcal} / \mathrm{kg}$.

- A linha de processamento e produção de CDR (Combustível Derivado de Resíduo) é necessária para garantir homogeneização do combustível. Utilizou-se mistura de RSU, resíduos agrícolas e de produção em proporção variável, de acordo com a geração de cada município. O PCI da mistura e umidade foram calculados considerando a proporção.

- Eficiência do sistema termoquímico para produção do gás de síntese de $75 \%$. Utilização de ciclo Rankine (caldeira aquatubular com eficiência média de $95 \%$ e turbina a vapor).

- Em Itapicuru, foram considerados também todos os resíduos agrícolas (culturas permanentes e temporárias) e resíduos de processamento (casca da castanha, casca e crueira da mandioca). Em Ribeirão Branco, foram considerados também todos os resíduos agrícolas (culturas permanentes e temporárias).

Comparando-se os resultados desta seção com o da seção 5.7.1., verifica-se que há um potencial maior possível de ser gerado com o sistema de gaseificação quando comparado com os sistemas de ciclo a vapor. Isto ocorre porque neste caso é possível aproveitar toda a disponibilidade de RSU juntamente com os demais resíduos de biomassa sólida, o que ocorre apenas com a tecnologia de gaseificação. A tecnologia de combustão de RSU (incineração) requer sistemas de limpeza dos gases de alta eficiência em virtude da formação de poluentes (dioxinas e furanos) com a incineração de plásticos e demais resíduos, o que eleva substancialmente os custos de geração e não se mostra viável para pequenos municípios (INFIESTA, 2015). Por este mesmo motivo, pode ser queimado em caldeira o gás de síntese produzido no gaseificador, porque praticamente não ocorre a formação de dioxinas e furanos 
no processo de gaseificação; para sua formação é necessária a presença de oxigênio, o que não ocorre na gaseificação (reação com quantidade de ar abaixo da estequiométrica).

Tabela 5.16: Resíduos utilizados e Potência disponível (MW) gerada por gaseificação nos municípios do estudo.

\begin{tabular}{|l|r|r|}
\hline & ITAPICURU & RIBEIRAO BRANCO \\
\hline RSU coletado (kg/ano) & 8.210 .656 & 4.588 .378 \\
\hline RSU coletado (kg/dia) & 22.494 & 12.570 \\
\hline RSU "gaseificavel" (t/dia) & 17,55 & 9,81 \\
\hline RSU "gaseificavel" (t/h) & 0,73 & 0,41 \\
\hline RESIDUO AGRICOLA & & \\
\hline Resíduo agricola (t/ano) & 81.316 & 65.800 \\
\hline Resíduo agricola (t/dia) & 222 & 180 \\
\hline Resíduo agricola (t/h) & 9,28 & 7,51 \\
\hline Total de residuos (t/h) & 10,01 & 7,92 \\
\hline Potência disponivel (MW) & 6 & 5 \\
\hline
\end{tabular}

Fonte: Estimativa dos resíduos, cálculos da autora; estimativa de potência a partir de Carbogás (2019).

\section{8 CÁLCULO DA DEMANDA PRODUTIVA DE ENERGIA}

Além de água potável, esgotamento sanitário e alimento, dentre outras necessidades básicas englobadas nas três dimensões consideradas pelo IDH (educação, longevidade e renda), o acesso à energia é primordial para o desenvolvimento humano e está relacionado com a elevação do IDH conforme visto em capítulo anterior.

As taxas de acesso à energia elétrica foram relatadas no capítulo 4 (acima de $90 \% \mathrm{em}$ ambos os municípios), e conforme Coelho \& Goldemberg (2013) pode-se estimar a potencial demanda de energia observando as seguintes fases: a) para cobrir as necessidades básicas como aquecimento, iluminação e cocção (50 a 100 kWh per capita por ano) e b) para uso produtivo como processos produtivos, agricultura, entre outros (500 a $1000 \mathrm{kWh}$ per capita por ano).

A tabela 5.17 mostra a demanda de energia suplementar para cada município a fim de cobrir os habitantes excluídos da taxa de acesso à energia, considerando uso para necessidades básicas (50 e $100 \mathrm{kWh}$ per capita por ano) e para uso produtivo (500 e $1000 \mathrm{kWh}$ per capita por ano), como um adicional a fim de incrementar as atividades econômicas das cidades. As seguintes equações foram utilizadas para os cálculos: 
Equação 29: demanda de energia para uso com necessidades básicas (50kWh per capita)

$$
\mathrm{DE}_{(50)}=\mathrm{n} \text {. habitantes } *(1-\text { taxa acesso }) / 100 * 50 \mathrm{kWh}
$$

Equação 30: demanda de energia para uso com necessidades básicas (100kWh per capita)

$\mathrm{DE}_{(100)}=\mathrm{n}$. habitantes $*(1-$ taxa acesso $) / 100 * 100 \mathrm{kWh}$

Equação 31: demanda de energia para uso produtivo (500kWh per capita)

$$
\mathrm{DE}_{(500)}=\mathrm{n} \text {. habitantes } * 500 \mathrm{kWh}
$$

Equação 32: demanda de energia para uso produtivo (1.000kWh per capita)

$$
\mathrm{DE}_{(1000)}=\mathrm{n} . \text { habitantes } * 1000 \mathrm{kWh}
$$

Tabela 5.17: Demanda calculada de energia anual nos diferentes cenários para os municípios estudados.

\begin{tabular}{|l|c|c|}
\hline Demanda de energia & Itapicuru (MWh) & Ribeirão Branco (MWh) \\
\hline Necessidades básicas 50 & 117 & 4,2 \\
\hline Necessidades básicas 100 & 233 & 8,4 \\
\hline Necessidades básicas - média & 175 & 6,3 \\
\hline Uso produtivo 500 & 16.131 & 9.135 \\
\hline Uso produtivo 1000 & 32.261 & 18.269 \\
\hline Uso produtivo - média & 24.196 & 13.702 \\
\hline
\end{tabular}

Fonte: cálculos obtidos pela autora

\section{9 CONCLUSÕES DO CAPÍTULO}

Após o cálculo do potencial de geração da energia a partir da biomassa residual produzida em ambos municípios, percebe-se que, com um olhar generalista, a gaseificação para resíduos sólidos, em paralelo à digestão anaeróbica para dejetos de animais, esgoto e manipueira, de forma combinada, podem representar significativo acréscimo na energia disponível para os municípios, tendo como grande benefício a questão ambiental pela sinergia com o saneamento básico.

No capítulo a seguir fez-se análise detalhada desses números. 


\section{ASPECTOS AMBIENTAIS, SOCIAIS E ECONÔMICOS DO APROVEITAMENTO ENERGÉTICO DA BIOMASSA RESIDUAL GERADA DOS MUNICÍPIOS - SINERGIAS ENTRE APROVEITAMENTO ENERGÉTICO E SANEAMENTO BÁSICO}

O capítulo anterior apresentou o cálculo de todos os resíduos gerados nos municípios, a partir da produção agropastoril e do número de habitantes. Utilizando-se de tecnologias viáveis para aproveitamento energético da biomassa residual, fez-se levantamento do potencial de geração de energia. Mas a importância e viabilidade da transformação de resíduos em energia não se atém apenas aos números, mas deve-se considerar as externalidades envolvidas.

Assim, nesse capítulo serão discutidas questões ambientais, sociais e econômicas que permeiam o aproveitamento energético da biomassa residual. A apresentação de efeitos deletérios do não aproveitamento desses resíduos por si só, ou seja, dele ser disposto ou manuseado de forma incorreta, explicam a importância e necessidade de melhor utilização dessa matéria prima como a proposta neste estudo que versa sobre aproveitamento energético de biomassa residual.

\section{1 ASPECTOS AMBIENTAIS}

Segundo a norma ABNT/NBR 14.001/2004, consideram-se aspectos ambientais aqueles que, sendo elementos da atividade, produto ou serviço de uma organização que têm interação com o meio ambiente. Estes seriam as "causas" e às "consequências" denomina-se impacto ambiental, podendo este ser positivo ou negativo (ABNT, 2004).

A vida humana, desde os primórdios, apropriou-se de recursos naturais para sua existência e manutenção. Porém, após a Revolução Industrial a voracidade sobre o uso dos recursos tornou-se mais expressiva. Não há como falar sobre aspectos ambientais sem envolver o conceito de sustentabilidade. A utilização de recursos naturais sem causar danos atuais ou a gerações futuras faz com que surjam movimentos na sociedade para criar soluções com a atenuação dos danos ambientais. A harmonização entre meio ambiente e desenvolvimento econômico é premente e está bem caracterizada nos 17 ODS da ONU (ONU, 2015). A fim de aprofundar a discussão nos aspectos ambientais, a análise será setorizada para resíduos agropastoris (incluindo dejetos de animais), esgoto urbano e RSU. 
Neste capítulo será dado enfoque nos aspectos ambientais caso não haja aproveitamento dos resíduos, sendo os mesmos dispostos de maneira inadequada. Porém cabe mencionar que cada tecnologia em si traz impactos ambientais, decorrentes dos efluentes, gases e outras substâncias por elas produzidas, em maior ou menor grau. Assim, para implantação de projetos de aproveitamento energético da biomassa residual, se faz necessário estudo desses impactos com possível implantação de medidas para mitigação dos mesmos até níveis preconizados por legislação vigente.

\section{1. 1 Resíduos agropastoris}

Segundo o manual elaborado pelo Banco do Nordeste e divulgado pelo Ministério do Meio Ambiente, são alguns impactos ambientais decorrentes da produção agrícola, referindose especificamente ao tratamento e disposição (inadequada) de resíduos (BNB, 1999):

- Poluição do ar por fumaça e material particulado decorrente de queimadas de resíduos vegetais para preparo das áreas agricultáveis (antes e após colheitas);

- Contaminação do solo, ar, água e flora por vestígios de agrotóxicos e fertilizantes presentes em resíduos vegetais dispostos de maneira inadequada;

- Não observância das Áreas de Proteção Permanente e Reservas Ecológicas principalmente ao longo de rios e cursos d'água devido a disposição inadequada de resíduos vegetais que não são utilizados para cobertura do solo.

Ao se referir à produção animal, o mesmo órgão cita os seguintes aspectos de acordo como sistema de criação:

- Em sistemas de criação extensiva, são subprodutos a urina e fezes dos animais além do gás metano (no caso de ruminantes), um dos gases de efeito estufa. Os dejetos eliminados de forma aleatória no solo têm efeito benéfico de fertilização, o que ocorre de forma contrária nos cursos d’água com altas taxas de evaporação e baixa taxa de renovação hídrica. Assim, açudes e represas tendem a ser contaminados, gerando danos à saúde das populações que consomem essa água, bem como interferindo na população de peixes e outros organismos aquáticos.

- O sistema de criação em confinamento, como é o caso de aves e suínos nos municípios estudados, gera concentração de dejetos sólidos e líquidos, podendo haver contaminação de águas superficiais e subterrâneas, geração de odores e contribuição na proliferação de vetores (roedores e insetos) caso não haja disposição adequada dos excrementos. 
Ainda sobre confinamento, caso os estábulos e granjas não sejam construídos com orientação técnica adequada, há possibilidade de acúmulo de gases (amônia, gás sulfídrico, metano entre outros) devido ao manejo incorreto de resíduos, possibilitando agravos à saúde humana e animal, inclusive do entorno. Se faz necessário, na elaboração e execução dos projetos de confinamento de grande porte principalmente, medidas de armazenamento, tratamento e disposição de dejetos sólidos e líquidos gerados, para que não haja risco de impactos ambientais negativos como a contaminação do ar, solo e recursos hídricos (BNB, 1999).

Abordando aspectos ambientais da agroindústria, representada nos municípios pelas unidades de beneficiamento da castanha de caju e pelas casas de farinha e fecularia em Itapicuru, as questões relacionadas aos danos ambientais dependem da matéria-prima e produtos em questão.

Há contaminação das águas superficiais e subterrâneas por efluentes gerados no processo produtivo, que no caso da mandioca possuem altos valores de demanda química e demanda bioquímica de oxigênio (DQO e DBO), sólidos suspensos e dissolvidos além de substâncias tóxicas (cianeto e ácido cianídrico), não tratados ou tratados parcialmente e dispostos de forma equivocada. Águas residuárias contaminadas podem comprometer a qualidade dos mananciais hídricos, com efeitos na microfauna e microflora do ambiente aquático. Nessa agroindústria, há também a contaminação do solo por cascas, resíduos sólidos e semissólidos acondicionados sem critério, que geram odores desagradáveis e atraem vetores, além da poluição do ar por fumaça e partículas derivadas da queima de lenha e carvão para secagem e torrefação da farinha (BNB, 1999)

No beneficiamento da castanha de caju, caso haja disposição incorreta de resíduos, há contaminação do solo por cascas, talos e frutos não aproveitados para outros fins, contaminação de águas residuárias provenientes da lavagem da castanha, além da poluição do ar por fumaça e partículas derivadas do cozimento da castanha e do uso de lenha ou cascas de castanha para tal (BNB, 1999).

\section{1.2 Esgotos}

Considerando os resíduos da atividade humana - esgoto e resíduos sólidos urbanos (lixo doméstico e comercial, restos de poda e varrição entre outros) é importante a análise desses 
temas pois são grandes problemas dos municípios brasileiros, inclusive dos destacados neste estudo.

Aproximadamente $80 \%$ do volume de água consumida transforma-se em esgoto, o qual deve ser tratado antes de disposto em corpos d’água. As características químicas, físicas e biológicas desse esgoto são muito variáveis de acordo com o uso dessa água.

Impactos ambientais negativos são decorrentes da concentração de sólidos suspensos, sólidos dissolvidos, nutrientes, matéria orgânica, óleos e gorduras, presença de substâncias tóxicas e microrganismos patogênicos. Esgoto sem tratamento tem grande potencial para gerar problemas à saúde como doenças parasitárias decorrentes do contato com fezes, hepatite A, e contaminação da água potável e alimentos, causando doenças gastrintestinais como cólera, febre tifoide entre outras (BNB, 1999).

O lançamento de esgoto sem tratamento também causa danos ao ecossistema aquático pela diminuição do oxigênio disponível na água e por bioacumulação, no caso de substâncias tóxicas. Caso esse esgoto seja despejado em açudes, lagoas, ou seja, em ambientes sem circulação da água, esse perigo aumenta pela alta concentração de poluentes. Nesse caso, também atividades de lazer são comprometidas uma vez que a população local costuma pescar, nadar e praticar esportes aquáticos nesses ambientes. Em casos extremos, o odor além de indesejado, costuma atrair vetores como insetos e roedores. No caso de esgoto tratado, o lodo resultante do tratamento também tem seu potencial poluidor e deve ter destinação adequada como o aterro sanitário (BNB, 1999).

No Brasil, dados do Sistema Nacional de Informações sobre Saneamento (SNIS) de 2018, indicam que $83,5 \%$ da população tem acesso a água tratada e 52,36\% tem coleta de esgotos sendo que $46 \%$ do esgoto coletado é tratado (TRATA BRASIL, 2019).

Assim, é possível analisar os impactos negativos do lançamento do esgoto cru e/ou tratado de forma incorreta no meio ambiente, lembrando que a taxa de coleta de esgoto em Itapicuru é de 11,4\% e, em Ribeirão Branco, 51,2\%:

- Efeito do lançamento em corpos d’água: contaminação de águas superficiais e subterrâneas;

- Efeitos no solo: contaminação por substâncias tóxicas e/ou patógenos; 
- Efeito no bioma: modificação da qualidade do habitat da fauna e flora aquáticos e do entorno dos mananciais hídricos, contaminação por metais pesados dos organismos biológicos pertencentes ao ecossistema;

- Efeitos na comunidade próxima, alterando sua qualidade de vida: presença de odores indesejados, atração de insetos e roedores transmissores de doenças, riscos à saúde devido à contaminação da água utilizada nas atividades diárias (beber, escovar os dentes, tomar banho, lavar louças e alimentos) e no consumo de alimentos irrigados com águas contaminadas (muitas vezes o consumidor encontra-se distante e sem conhecimento do fato), situação delicada quando a região é grande produtora principalmente de hortaliças, como é o caso de Ribeirão Branco.

O lançamento de esgoto em corpos d'água sem o devido tratamento causa efeitos deletérios na saúde da população que circunda essas regiões ou que consome água e alimentos provenientes dessas áreas e serão abordados com maior profundidade no item 6.2 na discussão sobre aspectos sociais.

\section{1. 3 RSU}

Os resíduos sólidos, também conhecidos como lixo pois são provenientes do descarte do que não tem mais utilidade, fazem parte de um dos maiores desafios da sociedade moderna. $\mathrm{O}$ consumismo e as novas necessidades surgidas (ou implantadas) fazem com que a produção de resíduos esteja maior a cada dia. Dados da Abrelpe mostram que a geração de RSU per capita cresceu 0,39\% no comparativo entre 2017/2018, atingindo mais de 216 mil toneladas dia no país, sendo que 92\% desse lixo foi coletado (ABRELPE, 2019). Esse volume de resíduos crescente, imposto por padrões culturais da sociedade industrial tem sofrido, inclusive, modificação na sua composição, causando aumento dos impactos na sua destinação.

A parcela não coletada vai parar em terrenos baldios, corpos d’ água, locais públicos entre outros, causando problemas para a saúde pública pela contaminação de solo e água e atraindo vetores e pragas urbanas.

A concentração de pessoas em áreas urbanas aumenta o problema, levando às prefeituras uma situação difícil de equacionar: grande volume de RSU e diminuição de locais para disposição do mesmo. O poder público, no caso das prefeituras, tem dificuldades de gerenciar a questão por questões políticas e financeiras.

A PNRS, promulgada em 2010, previa a disposição adequada do RSU até 2014. Esse prazo foi prorrogado e, para municípios com menos de 50 mil habitantes, esse prazo se 
encerraria em 31/07/2021, mas as prefeituras brasileiras, incluindo as desse estudo, têm dificuldades de se adequarem à essa legislação (BRASIL, 2015). A legislação em questão preconiza que na gestão do RSU o mesmo deve passar por processos para aproveitamento e tratamento, como a reciclagem, por exemplo, antes da disposição final do rejeito em condições adequadas, sendo possível seu aproveitamento energético através de tecnologias adequadas (GARCILASSO e FERRAZ JUNIOR, 2018).

Comparando dados de 2017/2018, o país teve um discreto aumento na disposição final adequada de RSU, mas $17,5 \%$ do RSU (quase 35 mil ton./dia) ainda vai para lixões. O Brasil tem 1493 municípios atendidos por lixões, sendo 56,5\% no Nordeste e 13,9\% na região sudeste (ABRELPE, 2019).

Os resíduos urbanos (comerciais, domiciliares e públicos) quando não dispostos de forma adequada constituem-se em permanente ameaça ao meio ambiente e à saúde coletiva. Se disposto em lixões, o contato com pessoas e animais pode acarretar transmissão de doenças.

Lixão é o nome genérico dado a local a céu aberto onde é disposto o RSU, sem nenhum critério técnico para evitar problemas ambientais e riscos à saúde pública. Como não há controle, não é possível saber ao certo tipo ou quantidade desse resíduo, podendo ser de baixa periculosidade, como o lixo doméstico, ou de alta periculosidade se for resíduo industrial ou hospitalar. Os lixões também atraem catadores que, muitas vezes residem próximos a eles, acarretando problemas de saúde a essas pessoas (adultos, idosos e crianças inclusive) (GARCILASSO e FERRAZ JUNIOR, 2018)

Além do odor desagradável, há desprendimento de gases tóxicos e cancerígenos como benzina e cloro vinil, além dos desprendidos pela decomposição da matéria orgânica como metano, $\mathrm{CO}_{2}$ e $\mathrm{H}_{2} \mathrm{~S}$. Caso haja queima desse resíduo, a fuligem compromete a qualidade do ar (BNB, 1999).

Há também a poluição visual, transformando a paisagem em visão degradante. O depósito inadequado do RSU no solo pode causar contaminação por microrganismos patogênicos e substâncias tóxicas como metais pesados e hidrocarbonetos clorados contidos no líquido formado na decomposição do resíduo - o chorume. Este penetra no solo com maior ou menor dificuldade a depender do tipo do solo, atingindo lençol freático. O chorume também pode ser carreado pela chuva para corpos d’água, contaminando águas superficiais (BNB, 1999). 
A taxa de coleta de lixo em Itapicuru é $87,16 \%$ e 98,3\% em Ribeirão Branco. Isso significa que parte do lixo gerado não é sequer coletado. Sua disposição em locais inadequados pode gerar obstrução de galerias de águas pluviais, poluição visual, desvalorização da terra, contaminação do solo e águas superficiais e subterrâneas. A queima de lixo e outros resíduos, hábito comum principalmente nas áreas rurais, gera fuligem com emissão de material particulado e gases que comprometem a qualidade do ar. A presença de RSU dispostos a esmo atrai vetores e pragas urbanas, tema a ser discutido com mais ênfase em tópico subsequente.

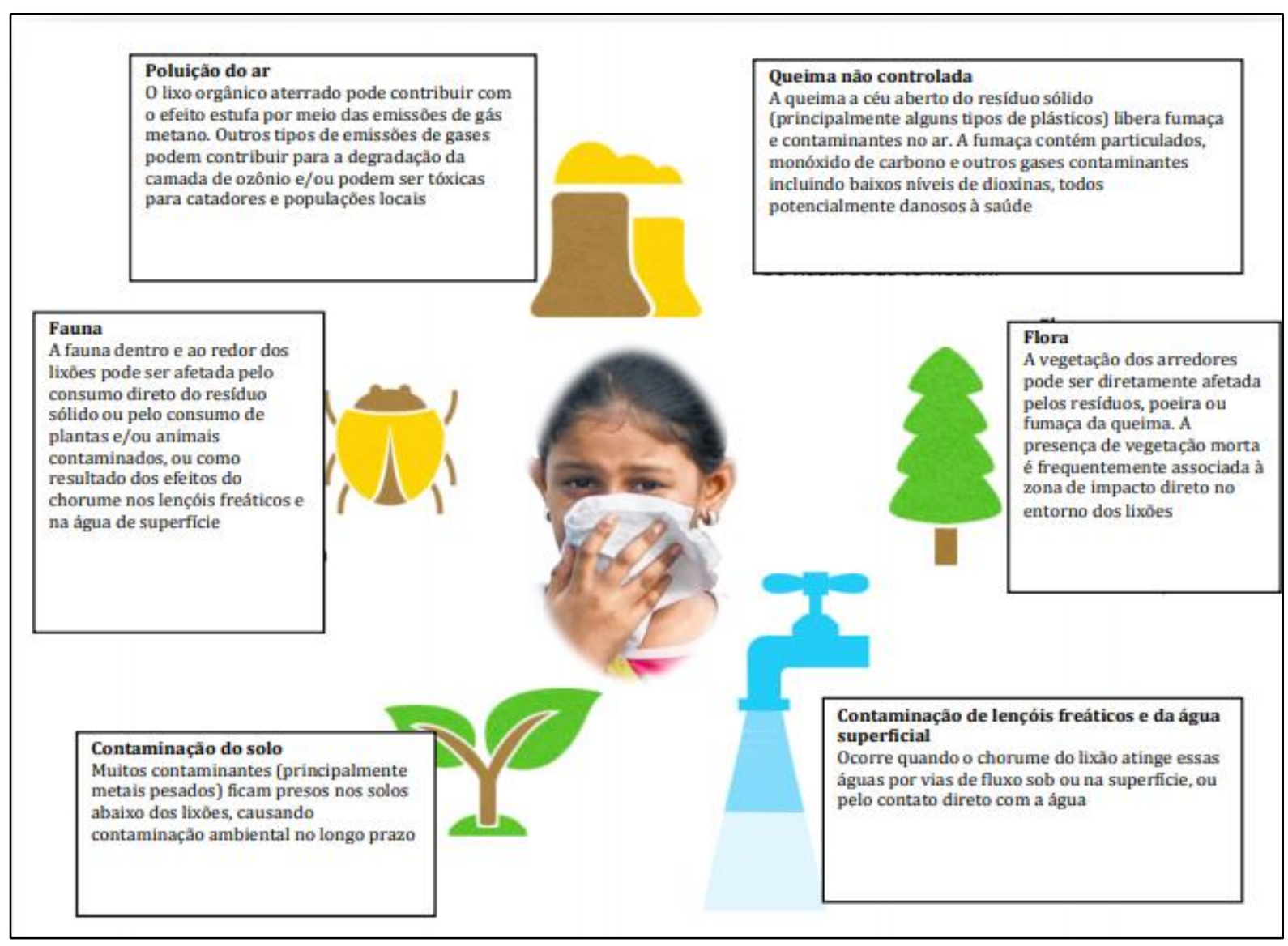

Figura 6.1: Interações de um lixão e o meio ambiente.

Fonte: Mavropoulos, 2015.

Após discussão sobre os impactos negativos da disposição incorreta de resíduos agropastoris, de produção, esgoto e RSU, é possível visualizar a importância do aproveitamento energético da biomassa residual pois, além de não causar os agravos mencionados acima ao meio ambiente, no caso da rota tecnológica utilizada ser a gaseificação, a mineração do lixo enterrado pode mitigar os danos causados pelo lixo disposto anteriormente em lixões ou locais sem controle, como será feito no município de Boa Esperança, caso citado no capítulo terceiro. 
Outra questão importante é a possibilidade de adequação dos municípios à legislação PNRS e Lei Federal do Saneamento (Lei 11.445/07), além de legislações estaduais adicionais porventura existentes, através do aproveitamento energético de resíduos diversos.

Durante a redação final desta tese, está em tramitação no Legislativo texto base para novo marco regulatório do saneamento básico, tendo como principais pontos a responsabilidade do município pela prestação do serviço, sendo permitida a participação da iniciativa privada por licitação entre outros, com metas para 2033 de 99\% da população com acesso à água potável e $90 \%$ com tratamento e coleta de esgoto. A previsão para fim dos lixões passa a ser entre agosto de 2021 a agosto de 2024, a depender da população e localização do município em questão e da existência de plano intermunicipal de resíduos sólidos ou plano municipal de gestão integrada de resíduos sólidos (BRASIL, 2019).

\section{2 ASPECTOS SOCIAIS}

Aspectos sociais referem-se a condições ou situações vivenciadas por uma sociedade. Então, tudo que se refere à determinada sociedade está contemplado no tema. $\mathrm{O}$ IDH tem seus indicadores baseados em três pilares: saúde, educação e renda, todos eles envolvidos com os aspectos sociais.

Embora aspectos ambientais, sociais e econômicos tenham imbricada ligação, como uma engrenagem que liga suas partes para o movimento harmônico do todo, neste tópico será dado enfoque à saúde e qualidade de vida. São considerados fatores macro determinantes da saúde as condições socioeconômicas, ambientais e culturais de uma população. Assim, modificações nesses aspectos refletem no processo saúde-doença (CNDSS, 2008).

A saúde pública há muito relaciona diretamente saneamento básico com qualidade de vida das populações. Aí estão englobadas atividades referentes ao abastecimento de água potável, coleta e disposição adequada de esgoto sanitário, manejo de águas pluviais e resíduos sólidos (incluindo a limpeza urbana).

Existe relação entre IDH e saneamento. Vê-se na figura 6.2 que, quanto maior a taxa de saneamento do país, mais bem colocado ele se encontra com relação ao IDH.

Dados mundiais referem que 570 mil crianças menores de cinco anos morreram por infecções respiratórias relacionadas à poluição de ambientes internos e externos em 2016 e, mais de 1.5 milhão de crianças nessa mesma faixa etária vão a óbito por problemas relacionados 
ao fornecimento inadequado de água potável, onde mais de 2 mil crianças por dia morrem devido à diarreia. A falta de saneamento tem impacto direto na saúde (TRATA BRASIL, 2019).

No Brasil, em 2013 foram mais de 340 mil internações e 2 mil óbitos por infecções gastrointestinais relacionadas ao consumo de água e alimentos contaminados, segundo dados do Ministério da Saúde. No país, ocorrem aproximadamente 15 milhões de afastamentos ao trabalho por ano, causados por diarreia ou vômitos, sintomas diretamente relacionados a doenças transmitidas por água e alimentos (DTA) (TRATA BRASIL, 2019)

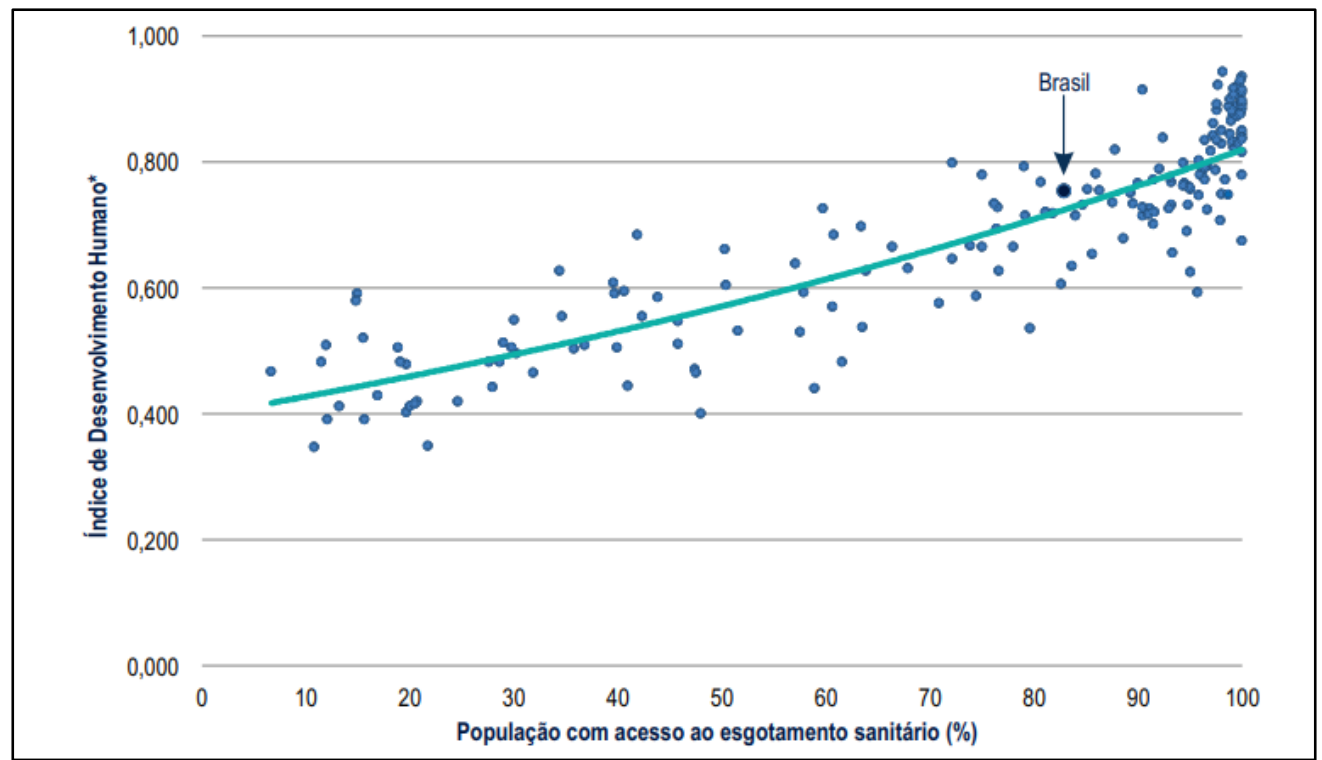

Figura 6.2: Saneamento e Desenvolvimento Humano. Dados de 2014.

Fonte: Trata Brasil (2018) com dados de UNICEF e WHO, 2015 e UNDP, 2015.

Analisando a realidade das cidades estudadas com dados do capítulo quarto, Itapicuru tem aproximadamente $89 \%$ dos domicílios sem esgotamento sanitário, $21 \%$ sem acesso ao abastecimento de água da rede e 13\% sem coleta de lixo. Esses dados explicam ainda 1,1 internações por diarreia a cada mil habitantes e mortalidade infantil de 19,66 óbitos / mil nascidos vivos.

A cidade paulista possui dados significativamente melhores, pois apresenta aproximadamente $49 \%$ dos domicílios sem esgotamento sanitário, $11 \%$ sem acesso ao abastecimento de água da rede e apenas $2 \%$ sem coleta de lixo. Esses dados são refletidos nas 0,5 internações por diarreia a cada mil habitantes e mortalidade infantil de 9,93 óbitos / mil nascidos vivos, já dentro das metas dos ODS. 
A queima ou destinação incorreta de resíduos agrícolas e RSU, bem como os resíduos de produção, dejetos de animais e esgoto lançados sem tratamento podem causar inúmeros agravos à saúde. As estatísticas apresentadas acima fazem bem essa correlação.

Nos países em desenvolvimento, as doenças do aparelho respiratório constituem alto grau de morbidade, sendo considerado que $60 \%$ delas refiram-se a poluentes ambientais. Crianças e idosos apresentam maior vulnerabilidade a esses poluentes, devido a peculiaridades de sua fisiologia. A queima indiscriminada de lixo e resíduos agrícolas é uma prática antiga e recorrente no Brasil, principalmente nas áreas rurais, onde são eliminados gases efeito estufa, substâncias tóxicas e material particulado que são transportados pelo vento, atingindo muitas vezes além dos moradores do entorno (GONÇALVES, CASTRO e HACON, 2012).

Esta realidade também é observada em Itapicuru e Ribeirão Branco onde o Censo de 2010 apurou que, conforme relatado no capítulo quarto, $40 \%$ e $23 \%$ dos domicílios respectivamente queimam o lixo na própria propriedade. A inalação de substâncias tóxicas provenientes da queima de resíduos, ou mesmo contato dérmico com solo contaminado por este procedimento, está relacionada com aumento de alguns tipos de câncer, anomalias congênitas e baixo peso ao nascer (GOUVEIA, 2012).

No caso de resíduos sólidos dispostos de forma inadequada, em lixões, valas ou mesmo aterros, favorecem a contaminação humana por lixiviação e percolagem do chorume bem como a dispersão de solo e ar contaminados. Estudos relacionam esta exposição a aumento risco de alguns cânceres e problemas ligados à gestação como anomalias congênitas, baixo peso ao nascer, abortos e mortes neonatais (GOUVEIA, 2012).

O manuseio desse material, inclusive para aqueles que tiram dele seu sustento garimpando material reciclável nos locais de acúmulo de resíduos (geralmente sem equipamento de proteção individual), envolve riscos de lesões, cortes e perfurações, picadas e mordida de animais, alterações na função respiratória, contaminação bacteriológica entre outros (GOUVEIA, 2012).

Em todas as situações de contaminação, os efeitos adversos à saúde dependem da via de exposição, do poluente, da quantidade ou dose, a duração e frequência de exposição. Os odores desagradáveis emanados por acúmulo de resíduos sólidos (principalmente biodegradáveis) e dejetos de animais são atrativos para insetos e podem causar enjoo, náuseas, dor-de-cabeça, fadiga e outros sintomas inespecíficos, afetando o bem-estar das populações (MAVROPOULOS, 2015). 
A presença de resíduos sólidos depositados aleatoriamente no solo pode favorecer o acúmulo de água das chuvas, tornando-se criadouro para larvas de mosquitos transmissores de doenças como zika, chicungunya, dengue e febre amarela, doenças que nos últimos anos vêm causando impactos na saúde pública, às vezes com sequelas permanentes como microcefalia em bebês nascidos de mães infectadas após a picada do mosquito Aedes aegypti.

A liberação de dejetos da atividade pecuária de forma não controlada além dos problemas ambientais pode acarretar danos à saúde humana. No caso da suinocultura, o contato com água, solo ou alimentos dos excrementos pode transmitir ao homem bactérias como Salmonella spp, E. coli, protozoários como Giardia spp, vírus diversos, verminoses e inúmeras outras doenças além de servir como substrato a larvas e, em excesso nas águas, causar mortalidade de peixes que são predadores naturais de insetos (GAMA, 2003). Tratando-se de aves, além de vírus, bactérias e protozoários presentes nas fezes, há de se observar que a poeira da cama de frango pode causar problemas alérgicos e respiratórios em humanos (EMBRAPA, 2007).

Como visto, inúmeros agravos à saúde decorrem da disposição incorreta de resíduos diversos, explicados acima. Assim, o aproveitamento de biomassa residual para geração de energia teria efeito positivo na saúde e qualidade de vida das populações de Itapicuru e Ribeirão Branco, por não mais oferecer os perigos descritos decorrentes da contaminação do solo, ar e água pelos resíduos agropastoris, RSU e esgoto provenientes das atividades produtivas e pela própria existência humana.

Além do bem-estar gerado às populações, há a economia gerada aos cofres públicos pela diminuição de gastos pelo sistema de saúde decorrente de doenças provocadas pela disposição equivocada de resíduos descritos acima, o menor número de ausências ao trabalho e à escola por incapacidade decorrente de doenças entre outros benefícios.

\section{3 ASPECTOS ECONÔMICOS}

Os tópicos acima explicaram a importância do saneamento básico (água, esgoto e resíduos sólidos) para melhor utilização de recursos naturais diminuindo a degradação do meio ambiente e seu impacto na saúde e qualidade de vida da população. Saneamento é medida indispensável para prevenção de doenças e promoção à saúde. Mas existem outras externalidades negativas.

O bem-estar físico, mental e social do indivíduo impacta na sua produtividade, pois trabalhador saudável está mais apto a um rendimento melhor. Surge assim, um primeiro 
impacto econômico. Dados estimam que a melhora na qualidade de vida tenha impacto positivo de $13 \%$ aproximadamente na produtividade, favorecendo crescimento de renda para as famílias. No caso de jovens e crianças, as doenças causadas pela falta de saneamento provocam afastamento das atividades escolares, diminuindo o desempenho escolar, impactando o desenvolvimento desses cidadãos para o mercado de trabalho e remuneração futura (TRATA BRASIL, 2018). Há de se observar que em Ribeirão Branco e mais ainda em Itapicuru, os indicadores na dimensão educação apresentam-se de forma insatisfatória.

Sob o tema economia, outro fator que se deve observar é o impacto no turismo. A deposição indevida de biomassa residual, em estado sólido ou semilíquido, além de possibilitar agravos à saúde, afeta a paisagem trazendo aspecto visual indesejado, odor desagradável e atração de pragas e vetores.

Itapicuru, por ser cidade bastante antiga, possui imóveis tombados pelo Instituto do Patrimônio Artístico e Cultural da Bahia (IPAC) com potencial para visitação. Outra atração turística é o Balneário Termal, alimentado por minas de águas medicinais para banhos terapêuticos. Ribeirão Branco, por sua vez, já consta no Mapa do Turismo Brasileiro (20192021) do Ministério do Turismo pois faz parte da Região Turística "Cânions Paulistas", com cachoeiras, trilhas na Mata Atlântica, fauna e flora bem preservadas, trabalhando para receber o título de Município de Interesse Turístico do Governo do Estado de São Paulo, com maior acesso a verbas públicas e geração de empregos. Outro impacto econômico reside na valorização das terras. Locais com manejo adequado de resíduos sofrem valorização monetária tanto na área urbana como na rural.

A utilização energética da biomassa residual traz um ganho econômico evidente, pois a geração de energia a partir de resíduos fornece um bem de incontável utilidade - a energia (elétrica, biogás, térmica). Esta energia pode ser empregada para a diminuição dos gastos atuais no uso doméstico (cocção, iluminação, aquecimento, informação, transporte) e uso produtivo (manejo das criações de galinhas e porcos, irrigação, beneficiamento de produtos agropastoris, entre outros), opondo-se aos crescentes custos de energia elétrica.

A energia gerada pela biomassa pode também fomentar uma expansão desses usos, tanto oferecendo maior conforto à sociedade como possibilitando outros usos produtivos (fabricação de artesanato com fibras, barro, madeira, alimentos e doces regionais e tudo que o empreendedorismo das comunidades criar). A redução da dependência de fontes externas de energia bem como a diminuição da transferência de recursos a terceiros (concessionárias de 
energia elétrica, gás natural e outros combustíveis) estimula o crescimento econômico que, por sua vez, impacta na saúde, educação, elevando como um todo a qualidade de vida da população.

Para o aproveitamento energético dos resíduos de biomassa (agropastoris, RSU e esgoto) é preciso a implantação de projetos para a construção de usinas, plantas de biodigestão entre outros. Isso traz também efeitos na economia local. São eles os diretos: as obras em si geram empregos e renda, expandindo a economia regional; os indiretos: materiais e insumos, mesmo que grande parte venha de outras localidades, são adquiridos nos municípios. $\mathrm{O}$ pagamento a terceiros (fornecedores de produtos e serviços) injeta dinheiro na economia local. O terceiro efeito - o chamado induzido, consiste na circulação monetária para diversos setores da economia local, decorrente dos salários e outras rendas do cidadão que se encaminham para vestuário, alimentação, moradia, entre outros, além da maior arrecadação de impostos.

Para a utilização de RSU como fonte energética, há necessidade de classificação e separação dos resíduos. Com isso, os catadores informais de material reciclado podem se fortalecer através de cooperativas para coleta seletiva, trazendo benefício socioeconômico para grande número de pessoas, geralmente sem qualificação e muitas vezes marginalizadas pela sociedade.

Abordando os aspectos econômicos, é preciso trazer à discussão os valores para implantação dos empreendimentos (equipamentos e estrutura) para aproveitamento energético dos resíduos de biomassa. Considerando a proposta de combinar gaseificação e digestão anaeróbica para esse aproveitamento energético, são essas duas alternativas tecnológicas descritas a seguir:

\subsubsection{Gaseificação}

As informações aqui apresentadas foram fornecidas pela Carbogás, a título de simulação para este estudo.

As vantagens desse processo, mais uma vez retomando, são:

- Tecnologia $100 \%$ nacional;

- Não exige filtros após a oxidação do gás, reduzindo custos e manutenções; 
- Não há formação de dioxinas e furanos, as cinzas podem ser usadas na sua totalidade como matéria prima industrial e não há formação de outros passivos, tornando o processo "zero waste”;

- Eficiência acima de 75\%;

- Tecnologia atende as resoluções ambientais CONAMA 316 e SMA 79, com valores até 50 vezes abaixo dos limites.

Como o processo depende da padronização das matérias primas (padronização do CDR - combustível derivado de resíduos) nos seguintes itens: granulometria (através de processos de trituração), umidade (através de processos de abatimento de umidade mecânicos e térmicos), PCI (através de processos de homogeneização) e remoção de inertes (através de processos de separação magnética, indutiva e densimétrica), a simulação de valores já envolve:

- Trituradores para ajuste de granulometria e abatimento mecânico de umidade;

- Secador rotativo para homogeneização e secagem térmica;

- Separadores magnéticos e de eddy-current para remoção de metais;

- Separadores aerólicos para a remoção de vidros e sedimentos

- Planta termoquímica (com o gaseificador);

- Geração elétrica com caldeira e turbina.

Assim, o valor total de uma planta de gaseificação para processamento de 300 toneladas por dia de RSU que dá aproximadamente $20 \mathrm{Gcal} / \mathrm{h}$ e $5 \mathrm{MWh}$ (valores que estão próximos aos cenários estipulados) fica em torno de R $\$ 83$ milhões (projeto "turn-key", ou seja, entregue pronto para operação conforme especificações). O custo anual de operação e manutenção é de $\mathrm{R}$ \$ 5 milhões aproximadamente. A operação gera em torno de 9 postos de trabalho por turno, incluindo operação e administrativo.

Embora o processo traga benefícios ambientais, socioeconômicos, energéticos, trata-se de valores altíssimos, não condizentes com a situação financeira das prefeituras envolvidas. Embora o investimento seja financiado pelo BNDES, parcerias são necessárias, como é o caso 
citado da Usina de Boa Esperança, que envolve a prefeitura do município, a Carbogás e a concessionária através de projeto de P\&D da Aneel.

\subsubsection{Biodigestão Anaeróbica}

A utilização de biodigestores na área rural traz três benefícios: geração de energia renovável, produção de fertilizantes e a mitigação dos problemas sanitários envolvidos com dejetos / efluentes.

Numa demonstração da formação de gás a partir de estrume e água, que no século XIX, Louis Pasteur, de forma incidental, mostrou que o biogás, conhecido desde o século XVII, era fonte de energia. Na década de 1940, a Índia começa a gerar energia a partir de dejetos de gado. No Brasil, embora com enorme plantel de bovinos, o sistema de criação extensivo em sua maioria impede o aproveitamento dessa biomassa. A avicultura, atividade com enorme expressão no país, também não se vale desse sistema de aproveitamento energético pois a "cama de frango" tem umidade abaixo da necessária para biodigestão, além de ter destino mais rentável como fonte de nitrogênio na área industrial (BNDES, 2018).

A suinocultura é responsável pela maioria do aproveitamento energético de dejetos animais, pela facilidade de coleta dos rejeitos, pela alta concentração de metano no biogás gerado e por características físico-químicas da matéria-prima. Entre as principais barreiras para o incremento desses projetos nas granjas, há ainda um mercado diminuto, necessitando fortalecer as políticas públicas para seu fortalecimento (inclusive com melhoria no marco regulatório), custo de equipamentos, financiamentos e estudos para divulgação de viabilidade econômica (BNDES, 2018).

A região sul, grande produtora de suínos e aves, concentra vários projetos de aproveitamento energético via digestão anaeróbica de resíduos animais, conforme exemplo citado no capítulo terceiro, do Projeto Ajuricaba no Paraná. Em, Santa Catarina e Rio Grande do Sul, existem grandes cooperativas como a Aurora, por exemplo, gerando biogás a partir de resíduos agropastoris.

Estudo realizado por Biasi e outros (2018), visitou 12 propriedades com produção de biogás no sul do país (PR, SC e RS), com dimensões de 7 a 1.200 hectares, abrigando 650 a 50 mil cabeças de suínos e 2 com vacas em lactação, sendo consideradas como agricultura familiar e outras não. Basicamente a estrutura era composta de galpões, lagoa de decantação, conjunto gerador, distribuidor de esterco líquido, tratores e um número variável de biodigestores (de 1 a 
18). A produção de biogás variou entre 75 a 6.400 m³/dia para utilização na geração de energia elétrica, térmica e sem uso energético (queima em flare). O investimento, próprio ou via bancária, variou entre $\mathrm{R} \$ 14.800$ (unidade sem uso energético) a $\mathrm{R} \$ 2$ milhões, com custo de manutenção estimado entre $\mathrm{R} \$ 450$ e $\mathrm{R} \$ 1.500$ mensais (BIASI et al, 2018).

O custo do investimento é bastante específico, pois depende da quantidade e tipo de resíduos (composição), área da propriedade, destino do biogás entre outros. Há casos em que a produção de biogás pode abastecer produção industrial. Caso citado em estudo, dejetos de 3 mil suínos, tratados em biodigestor modelo lagoa coberta com volume de $2.000 \mathrm{~m}^{3}$ teve investimento de $\mathrm{R} \$ 300$ mil (financiamento através do Programa ABC) e manutenção mensal de R \$ 1.500, abastecendo forno de cerâmica que economiza R 20 mil por mês em energia elétrica (BIASI et al, 2018).

No mesmo estudo citado acima, é apresentada modelagem para viabilidade econômica de um empreendimento com 2.300 suínos em terminação, produzindo aproximadamente 11 mil $\mathrm{m}^{3} / \mathrm{mês}$ de biogás que geram em torno de $17 \mathrm{mil} \mathrm{kWh} /$ mês. Os custos para geração distribuída interligada (biodigestor, grupo moto-gerador, painel elétrico e painel de conexão em GD) ficaram em R\$ 156.640. Ao final, chega-se ao resultado de payback simples em 5,1 anos considerando juros de 6,5\% a.a. (BIASI et al, 2018).

Estudo realizado por Souza e outros (2004) avaliou custo da eletricidade gerada em conjunto motor gerador utilizando biogás da suinocultura. A viabilidade depende da tarifa corrente de energia na localidade, das condições de financiamento, da amortização considerada entre outros. Mas concluiu-se que a utilização do conjunto motor gerador operando $10 \mathrm{~h} / \mathrm{dia}$ traria um retorno em 5,4 anos com um custo de R\$ 190,00 / MWh.

Calza e outros (2015), avaliando custos de implantação de biodigestores e da energia produzida pelo biogás, a partir de dejetos de suínos, caprinos e bovinos em Cascavel (PR), concluiu que, embora a maior produção anual de energia foi verificada para gado bovino, a energia com suínos apresentou menor custo (entre 0,015 e $0,050 \mathrm{R} \$ / \mathrm{kWh}$ ) em biodigestor modelo canadense, que apresentou menor custo de construção e implantação conforme tabela 6.1.

A Embrapa Suínos e Aves, localizada em Concórdia (SC), suporta a Rede BiogásFert, que se baseia no projeto "Tecnologias para produção e uso de biogás e fertilizantes a partir do tratamento de dejetos de animais no âmbito do plano ABC", com muitas publicações sobre o 
tema, visando estratégias para desenvolvimento sustentável com foco em agricultura de baixo carbono.

Tabela 6.1: Custos para implantação e construção de biodigestores modelos Indiano, Chinês e Canadense por diferentes capacidades

\begin{tabular}{|c|c|c|c|}
\hline Capacidade do Biodigestor $\left(\mathrm{m}^{3}\right)$ & \multicolumn{3}{|c|}{ Custo total por modelo de biodigestor (R\$) } \\
\hline & Indiano & Chinês & Canadense \\
\hline 20 & $5.065,70$ & $4.052,50$ & $2.104,00$ \\
\hline 40 & $7.099,30$ & $5.679,40$ & $3.162,00$ \\
\hline 60 & $9.440,20$ & $7.552,10$ & $4.188,00$ \\
\hline 80 & $11.470,90$ & $9.176,70$ & $5.214,00$ \\
\hline 100 & $12.486,30$ & $10.801,40$ & $6.240,00$ \\
\hline & $14.178,60$ & $12.426,00$ & $7.266,00$ \\
\hline
\end{tabular}

Fonte: Calza e outros (2015).

Em determinada circular técnica, faz levantamento de biodigestor para tratamento de dejetos em aviário de frangos de corte. O biogás produzido é utilizado para geração de energia térmica na própria granja, em sistema integrado. A implantação do sistema (biodigestor de $150 \mathrm{~m}^{3}$ ), incluindo montagem do equipamento (lona de PVC), equipamento para compressão e purificação do gás, tubulação, unidade de aquecimento (fornalha, queimador e distribuição no aviário) e estrutura para armazenamento de dejetos ficou em aproximadamente $\mathrm{R} \$ 29$ mil reais (EMBRAPA, 2005).

Finalizando os aspectos econômicos da geração de energia pelo aproveitamento da biomassa residual, é importante considerar que todas as operações financeiras envolvidas nos processos descritos acima geram impostos para as esferas Municipal, Estadual e Federal. Essa arrecadação teoricamente deve voltar como benefício à sociedade na forma de saúde, educação, segurança e diversos outros serviços prestados aos cidadãos.

\section{4 SINERGIA ENTRE APROVEITAMENTO ENERGÉTICO E SANEAMENTO BÁSICO}

O mundo moderno possui grandes desafios. Um deles é descobrir até onde o planeta tem capacidade de suprir a crescente demanda da população por recursos naturais e como equacionar a convivência de mais de 7 bilhões de pessoas com a exaustão dos recursos hídricos, 
o aquecimento global, o consumismo crescente, a necessidade por alimentos e o acesso à energia limpa.

A pressão dos países em desenvolvimento por aumento no acesso à energia para elevar o padrão de vida das populações poderá gerar tensões e conflitos. E a sociedade com menor acesso à energia moderna e eficiente, como a eletricidade, certamente é a que mais sofre. Estudos mostram que desenvolvimento e sustentabilidade não são incompatíveis (GOLDEMBERG, 2008).

A Agenda 2030 para o Desenvolvimento Sustentável, com seus 17 ODS e 169 metas, traz uma forma de concretizar os direitos humanos de todos, não compactuando com a desigualdade de qualquer tipo. Nesta agenda, as três dimensões do desenvolvimento sustentável estão contempladas de forma equilibrada, mostrando a íntima ligação que devem ter aspectos ambientais, sociais e econômicos.

Nesta tarefa hercúlea, o alvo somente será atingido caso seja possível trabalhar em cooperação. Assim, a sinergia entre aproveitamento energético e saneamento básico é indispensável. Todo esforço para geração de energia através de biomassa proveniente de resíduos da atividade humana contribui diretamente para o saneamento básico, como foi discutido item a item neste estudo, acarretando diversos impactos positivos e evitando tantos outros negativos.

Ao se pensar no investimento para a implementação de usinas e plantas de biodigestão para utilização energética dos resíduos, há de se considerar todo benefício direto e indireto que ocorrerá na saúde, educação e qualidade de vida, não só dos diretamente envolvidos mas de toda a população do município que será afetada de alguma forma, a curto, médio ou longo prazo com esta iniciativa.

Além de não competir com a terras agricultáveis para a produção de alimentos, o uso de resíduos para geração de energia auxilia no saneamento básico, pois pode-se considerar cada usina de aproveitamento energético uma "unidade multitarefa", pois além de gerar energia, auxilia o saneamento ambiental e, no caso de biodigestão, pode tornar-se uma fornecedora de biofertilizantes.

O conceito de agroecologia pode ser aplicado aqui, pois o aproveitamento energético de resíduos agropastoris pode contribuir para uma agricultura moderna e agroecológica, onde novas tecnologias se unem a métodos tradicionais de manejo para conservação hídrica, 
manutenção da qualidade ambiental e aumento de produtividade através da energia gerada (EMBRAPA, 2019). Como Itapicuru e Ribeirão Branco são municípios com vocação para o agronegócio, a sinergia se faz novamente presente pois há o aumento na qualidade do saneamento ambiental contribuindo para a preservação e conservação de recursos naturais, essenciais para a produção agropastoril e indispensáveis à qualidade de vida.

Por tudo que foi exposto, pode-se inferir que os indicadores de renda, educação e saúde tomarão movimento ascendente, acarretando a elevação do IDHM dos municípios.

\section{5 CONCLUSÕES DO CAPÍTULO}

O aproveitamento energético da biomassa residual deve ser analisado considerando os diversos aspectos envolvidos São aspectos ambientais: a redução da poluição do ar, contaminação do solo e recursos hídricos, adequação à legislação e possibilidade de preservação de fauna e flora.

Aspectos sociais principais a serem considerados envolvem a redução de agravos à saúde (internações e óbitos) e economia junto ao sistema público de saúde. Os aspectos econômicos envolvidos são: impacto positivo no turismo e valorização imobiliária, diminuição de gastos com energia atual, novos usos produtivos para energia excedente, circulação monetária e arrecadação de impostos.

Existe grande sinergia entre aproveitamento energético e saneamento básico. Todo esforço para geração de energia através de biomassa proveniente de resíduos da atividade humana contribui diretamente para o saneamento básico e o cumprimento das metas da Agenda 2030. 


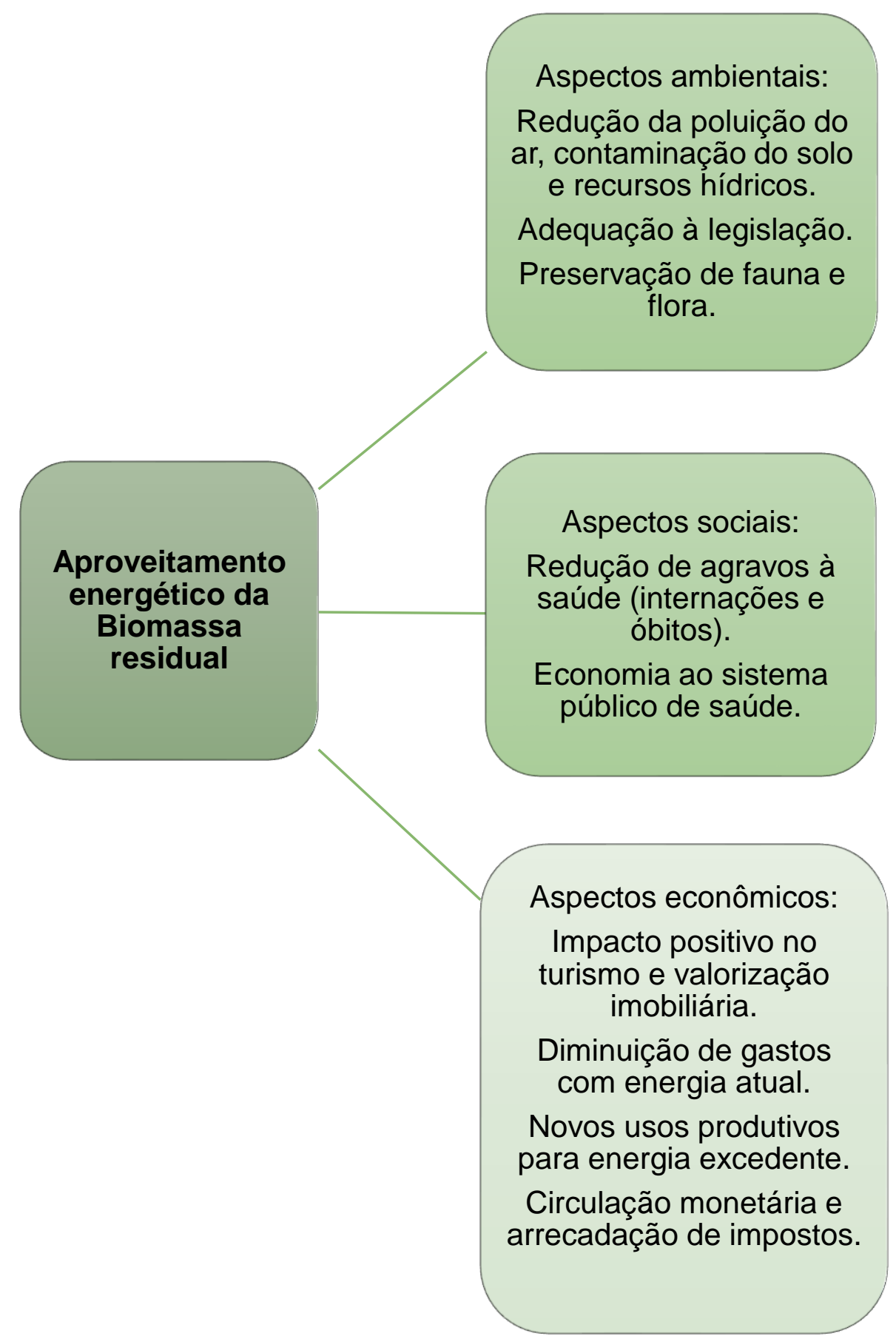

Figura 6.3: Apresentação esquemática do aproveitamento energético de biomassa residual e seus principais aspectos.

Fonte: a autora. 


\section{ANÁlise DAS BARREIRAS E SUGESTÃo DE MEDIDAS PARA VIABILIZAÇÃO DA UTILIZAÇÃO DA BIOMASSA RESIDUAL COMO FONTE DE ENERGIA}

Ao longo desta tese, discutiu-se sobre desigualdades, indicadores de desenvolvimento, acesso à energia e tecnologias para uso da biomassa residual como fonte de energia. A seguir, foram levantados dados socioeconômicos dos municípios estudados (Ribeirão Branco e Itapicuru), incluindo a quantidade de resíduos existentes. A partir da seleção das tecnologias mais adequadas em cada caso, estimou-se o potencial técnico de geração de energia a partir de resíduos agropastoris, RSU e esgoto.

Discutiu-se sobre aspectos ambientais, sociais e econômicos da utilização desses resíduos com fonte energética e a sinergia entre aproveitamento energético e saneamento básico, ficando explícito os benefícios da utilização energética dos resíduos. Neste capítulo, é preciso contextualizar a situação do país e das localidades estudadas, indicando barreiras e possíveis medidas para que sejam suplantadas, viabilizando a hipótese de que a utilização de biomassa residual possa ser utilizada para geração de energia complementar e, assim, promover desenvolvimento sustentável elevando o IDHM de Itapicuru e Ribeirão Branco.

Neste capítulo, são analisados os casos do setor elétrico, da situação do resíduo sólido urbano e dos resíduos agropastoris. Posteriormente, barreiras econômicas e outras são trazidas à discussão para então sugerir estratégias a fim de minimizar as barreiras e tornar possível o aproveitamento energético da biomassa residual.

\subsection{CONTEXTO ATUAL - SETOR ELÉTRICO}

As características de dimensões continentais do país e o uso de muitas fontes de energia viáveis faz com que o Setor Energético do país, além de sua importância inerente ao progresso, tenha desafios constantes, entre eles de estrutura e abastecimento.

Com a posse do novo Governo Federal em 01/01/2019, medidas econômicas vêm sendo tomadas para alavancar o crescimento do Brasil. Para tal, o setor energético deve estar preparado para que não voltemos aos "apagões". A forte recessão econômica vivida no país nos últimos anos, conforme visto na figura 7.1, e a lenta retomada de crescimento impacta investimentos no setor que certamente sofrerá grandes modificações nos próximos anos pela viabilização de novas tecnologias para aproveitamento de fontes renováveis e por eventuais 
correções nas distorções para a vitalização do setor, que é fundamental para o desenvolvimento da nação (EPE, 2018).

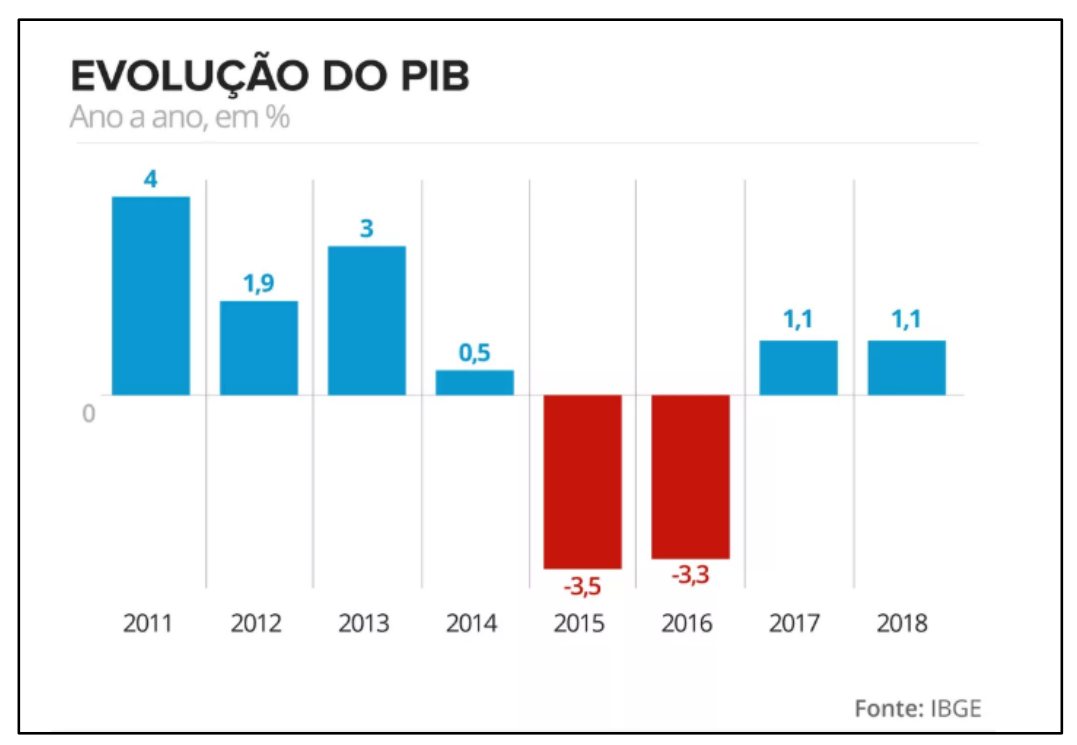

Figura. 7.1: Evolução anual do PIB em \%.

Fonte: G1 (2019).

O fornecimento de energia elétrica atualmente provém de sistemas isolados e o sistema interligado. Sistemas isolados - aqueles que em sua configuração normal não estão conectados ao SIN - Sistema Interligado Nacional, existem em aproximadamente 250 localidades, grande parte localizadas na região Norte, devido às dificuldades geográficas e enorme extensão. O SIN é um sistema hidro-termo-eólico de grande porte, responsável pela produção e transmissão da energia, constituído por quatro subsistemas ( $\mathrm{S}, \mathrm{SE} / \mathrm{CE}, \mathrm{NE}$ e parte da região $\mathrm{N}$ ), interconectado pela malha de transmissão que, através da otimização de recursos, possibilita atendimento ao mercado com segurança e economicidade. Sua operação, coordenação e controle estão a cargo do Operador Nacional do Sistema Elétrico (ONSE) e sob regulação e fiscalização da Agência Nacional de Energia Elétrica - ANEEL (EPE, 2019; ONS, 2019).

O Programa Nacional do Acesso e Uso da Energia Elétrica - Luz Para Todos, descrito no capítulo terceiro, foi instituído em 2003 e teve metas e prazos reajustados até 2022. Dados apontam que desde 2004, 3,4 milhões de ligações foram feitas pelo programa beneficiando mais de 16 milhões de pessoas no meio rural do país, com recursos da Conta de Desenvolvimento Energético (CDE), na forma de subvenção econômica (ELETROBRAS, 2019). O orçamento para o programa LPT em 2019, ficou em mais de R $\$ 1$ bilhão, beneficiando quase 400 mil 
moradores sem acesso à energia elétrica no meio rural. A Bahia é o estado com maior número de ligações a serem efetuadas (BRASIL. MME, 2018).

O Programa prevê atendimento de eletricidade para as necessidades básicas de iluminação, refrigeração e comunicação das unidades consumidoras, sendo que mais da metade dos beneficiários possuem renda menor que um salário-mínimo. Custos para eletrificação acima disso ficariam para o consumidor, bem como operação e manutenção, o que inviabiliza em muitos casos o uso da eletricidade para fins produtivos pela baixa condição de investimento das populações envolvidas. Grande benefício deste programa governamental foi ratificar o acesso à eletricidade como um direito civil, e que a universalização da eletricidade é de grande importância para se atingir as metas dos ODS (BRASIL. MME, 2019).

Falando de geração de energia, em contraponto à geração centralizada, onde uma grande fonte necessita de um sistema de transmissão e distribuição para que a energia chegue ao consumidor final, há a geração distribuída que permite, desde 2012, que o consumidor gere sua energia elétrica através de fontes renováveis ou cogeração, podendo disponibilizar na rede o excedente.

As modalidades micro (potência instalada até $75 \mathrm{~kW}$ ) e minigeração (entre $75 \mathrm{~kW}$ e 5 MW - outras fontes não hídricas) merecem ser estimuladas pelos impactos positivos como a economia financeira ao consumidor a médio / longo prazo, baixo impacto ambiental, a minimização de perdas elétricas, diversificação da matriz energética entre outros. Há possibilidade da utilização desse sistema em condomínios ou cooperativas, surgindo a figura da geração compartilhada.

A norma 482/2012 lançou as bases para a geração distribuída, com suas regras que foram alteradas pela resolução 687/2015. Em outubro de 2019, a ANEEL abriu para consulta pública propostas para a revisão das normas vigentes, sugerindo aperfeiçoamento ao modelo do sistema de compensação de créditos pelo avanço da geração distribuída, que atualmente conta com mais de 1.300 MW de potência instalada. Segundo a ANEEL, as modificações na tarifação são necessárias para ajustar custos entre consumidores que geram e que não geram sua energia, como o uso da rede de distribuição e outros encargos, o que aumentará o tempo de retorno dos investimentos em geração distribuída (ANEEL, 2019). 
Atualmente existem linhas de financiamento específicas para renováveis, em bancos públicos e privados, como o Banco Nacional de Desenvolvimento Econômico e Social (BNDES), Banco do Brasil, entre outros.

\subsection{RESÍDUOS SÓLIDOS URBANOS}

Tema de indiscutível importância, a gestão adequada de resíduos conforme prevista no PNRS proporciona impactos positivos em diversos setores conforme discutido no capítulo sexto, além de garantir direito ao meio ambiente equilibrado conforme prevê a Carta Magna do país, indispensável para o desenvolvimento sustentável. Dados nacionais de 2018 indicam geração de RSU per capita de 1,039 kg/hab./dia com coleta de 0,956 kg/hab./dia, ambos valores crescentes em todas as regiões do Brasil. Porém, se a cobertura da coleta atinge 92,01\% no país, em termos regionais vê-se 98,07 \% no Sudeste e apenas 81,08 no Nordeste (ABRELPE, 2019).

Amparada pela Lei 12.305/10, a PNRS prevê a responsabilidade compartilhada por todos os atores envolvidos na sociedade, desde a geração, distribuição e consumo de bens no compromisso de gerar menor impacto possível no meio ambiente, causada pela disposição inadequada dos resíduos. Ações para a diminuição da geração de resíduos, aproveitamento dos mesmos para outros fins e seu destino adequado fazem parte do cerne da PNRS (BRASIL, 2010). Entretanto, quando esta tese estava sendo finalizada (dez de 2019) o Congresso Nacional adiou mais uma vez o prazo para cumprimento dessa lei, até agosto de 2024 como no caso dos municípios em estudo (BRASIL, 2019).

Com a entrada em vigor na nova lei, a coleta seletiva passa a ser estimulada. Atualmente, segundo pesquisa direta da ABRELPE, 73,1\% dos municípios tem alguma iniciativa de coleta seletiva (no Sudeste 89,7\% e 54,0\% no Nordeste) (ABRELPE, 2019). Nos dois municípios aqui estudados, verificou-se atividade de coleta seletiva através de cooperativas, o que facilita o comércio do material reciclável, porém os volumes pequenos, como é o caso de Itapicuru e Ribeirão Branco, podem trazer dificuldades na correta valorização desse material para os catadores, surgindo a figura de intermediários.

Atualmente, fica a cargo do município a elaboração, implantação, fiscalização e revisão de um Plano Municipal de Gestão Integrada de Resíduos Sólidos (PMGIRS), podendo eles se organizarem em consórcios para organização e cumprimento das metas estabelecidas. Os gestores públicos deveriam ter iniciativas muito mais abrangentes do que a simples extinção dos lixões, pois as medidas contidas no PMGIRS devem ter visão abrangente, estruturadora e multidisciplinar sobre o tema. 
Segundo dados da Pesquisa de Informações Básicas Municipais 2017 feita pelo IBGE, nenhum dos dois municípios estudados apresentava PMGIRS nas bases do PNRS na ocasião. Segundo a mesma pesquisa, Ribeirão Branco não tem nenhuma legislação ou instrumento de gestão ambiental. O município baiano possui instrumentos legais sobre gestão de bacias hidrográficas, poluição do ar, destino de embalagens de agrotóxicos, proteção à biodiversidade e de adaptação e mitigação de mudanças do clima (IBGE, 2019). A falta de instrumentos legais, nem que seja inserida na Lei Orgânica do Município, Plano Diretor ou Código Ambiental, consiste em barreira à destinação correta de resíduos e possível aproveitamento energético.

A figura 7.2 mostra a destinação final do RSU no Brasil, Nordeste e Sudeste em percentuais. Os dados de 2018 demonstram o quanto ainda o território nacional está distante do cumprimento da PNRS, com destaque negativo para a região Nordeste, onde está localizada Itapicuru. Além da falta de legislação, a situação financeira dos municípios impacta na capacidade de investimento necessário para a solução dos problemas relacionados à disposição equivocada dos resíduos.

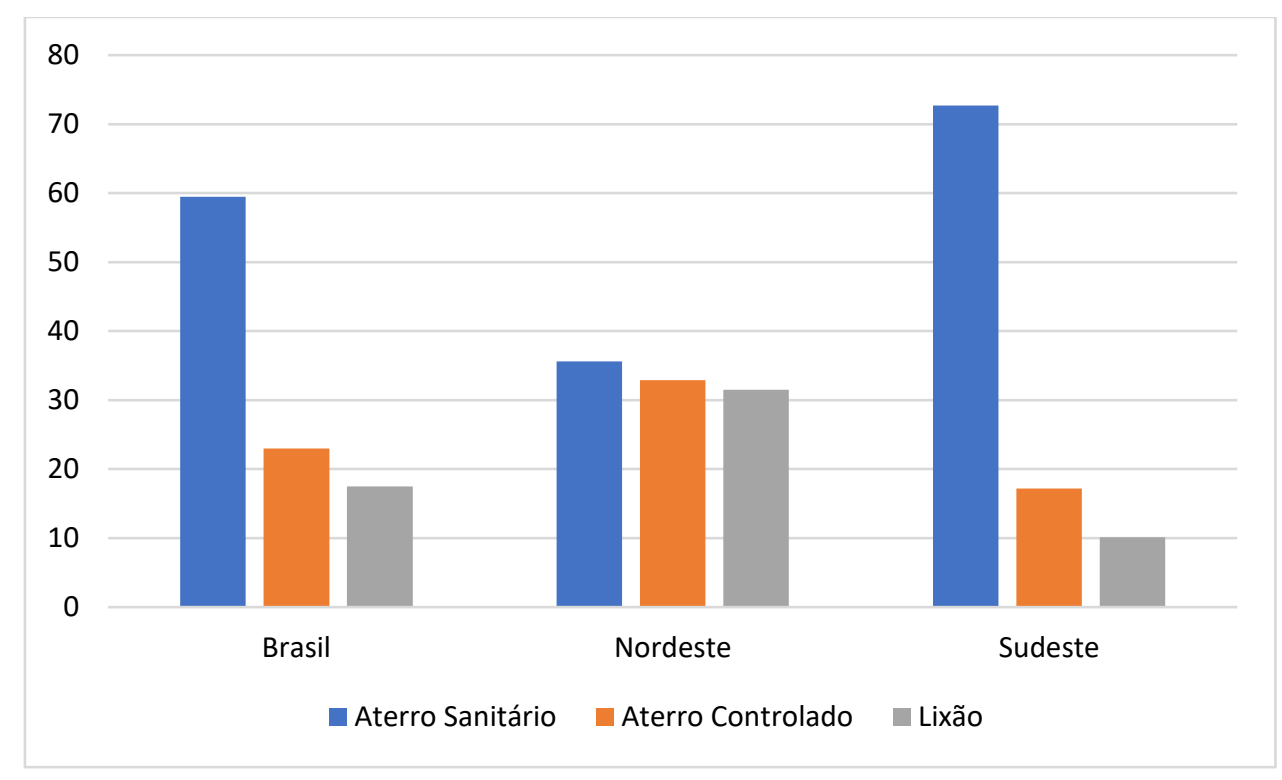

Figura 7.2: Disposição final (\%) de RSU no Brasil e nas regiões dos municípios estudados. Fonte: elaborado pela autora com dados de ABRELPE (2019).

Os municípios brasileiros têm basicamente três tipos de receitas: as tributárias, as orçamentárias e as de transferência de entes públicos em esferas superiores (estados e federação). Quanto às despesas, existem as com pessoal e encargos (ativos e inativos), terceirizados, material de consumo, pagamento de dívidas, aquisição de ativos, despesas 
operacionais diversas entre outras. Quanto mais as despesas fixas comprometam o orçamento público, menor a capacidade de investimento das prefeituras. Nordeste e Sudeste apresentam maior participação de municípios em situação crítica (com mais de $90 \%$ de suas despesas em mão-de-obra), acima da média nacional (OIM, 2019). E como já foi visto no país, governantes que assumem não dão continuidade às ações de antecessores, causando mais prejuízo ao município, muitas vezes postergando a solução de problemas para seus sucessores.

A tabela 7.1 mostra a situação fiscal em ambos os municípios - Itapicuru e Ribeirão Branco, considerando dados de 2017. A partir dela, é possível verificar a baixa capacidade de investimento dos dois municípios em estudo.

Tabela 7.1: Resultado fiscal de 2017.

\begin{tabular}{|l|c|c|}
\hline & Itapicuru & Ribeirão Branco \\
\hline Receitas (em milhares de reais) & $80.933,00$ & $41.622,00$ \\
\hline Despesas liquidadas (em milhares de reais) & $68.593,00$ & $36.678,00$ \\
\hline Nível de investimento (\%) & 5,80 & 4,73 \\
\hline Endividamento bruto (\%) & 13,52 & 22,68 \\
\hline
\end{tabular}

Fonte: Meu Município (2019)

Como se observa, a utilização de RSU para geração de energia ultrapassa a questão energética pois trata-se de possível solução para a adequação ao PNRS, transformando o passivo ambiental em ativo econômico e trazendo saúde e desenvolvimento para as populações. No presente caso, o maior empecilho é a reduzida quantidade de resíduo gerada.

Atualmente, existem três tecnologias comercialmente disponíveis para esse aproveitamento, como discutido no capítulo terceiro: a incineração, o aproveitamento do biogás de aterros através da biodigestão anaeróbica que ocorre com a fração orgânica dos RSU depositados nos aterros sanitários (COELHO, 2018) e a gaseificação.

A incineração ainda não é comum no Brasil, com apenas uma planta em licenciamento em São Paulo, no município de Barueri (ABES, 2015). Há questões de viabilidade econômica, mas reduz em até $90 \%$ o volume de material que é encaminhado ao aterro posteriormente. $\mathrm{Na}$ 
incineração há formação de dioxinas e furanos, o que faz com que seja necessário sistemas especiais de limpeza dos gases formados no processo. Por este motivo, esta tecnologia possui elevado custo de implantação, manutenção e operação (EPE, 2014; Coelho et al, 2019), o que faz com que tenha viabilidade apenas em municípios maiores, com população acima de 500 mil habitantes, o que corresponde a 48 municípios de acordo com estimativa do IBGE, ou seja, menos de $10 \%$ da quantidade total dos municípios brasileiros (IBGE, 2019).

Por sua vez, o aproveitamento do biogás captados nos aterros para utilização acontece em motores ciclo Otto, sendo realidade em grandes cidades brasileiras. O uso de turbinas a biogás ainda não ocorre no Brasil. As condições do aterro, composição do resíduo e o projeto interferem na quantidade de biogás produzido. Esta rota não reduz significativamente o volume do RSU e, a partir do encerramento do depósito de resíduo no aterro pela capacidade do mesmo, a formação de biogás entra em declínio. Atualmente, se tornaram viáveis os investimentos para aproveitamento do biogás, como ocorre em vários aterros (Aterro São João, Bandeirantes e Caieiras, em São Paulo, Termoverde em Salvador, Caucaia, em Fortaleza, entre outros) (EPE, 2014; COELHO, 2018).

A gaseificação ainda enfrenta desafios técnicos e econômicos, mas já existe atualmente em operação uma planta piloto (200 kWe), da Carbogás, em Mauá, São Paulo, e uma planta de 1 MWe em construção no município de Boa Esperança (40 mil hab), MG, num projeto P\&D Furnas ANEEL. Este projeto da Usina de Boa Esperança, descrito no capítulo terceiro, a depender dos estudos de viabilidade, trará benefícios na redução significativa no volume de RSU, com impactos ambientais positivos, mas como projeto pioneiro merecerá atenção para novas pesquisas e análise de resultados.

Há também informações de uma solução para gaseificação do RSU sendo oferecida pela WEG, para municípios com população entre 100 a 130 mil habitantes. Em todas as situações há necessidade de processar os RSU (separação, secagem e trituração), produzindo os chamados Combustíveis Derivados de Resíduos (CDR) a serem alimentados no gaseificador (BRASIL. MME, 2019).

A opção de gaseificação, como já discutido, se apresenta como uma importante opção para eliminação dos lixões nos pequenos e meios municípios, onde a incineração não se viabiliza economicamente. 
Por outro lado, a barreira derivada do baixo volume de RSU produzido pelos municípios pode ser compensada com a formação de consórcios entre municípios para utilização das usinas de aproveitamento energético. Itapicuru tem várias cidades a pequena distância (menor que $50 \mathrm{~km}$ ) como Olindina, Crisópolis, Tobias Barreto, Nova Soure, Rio Real, Cipó entre outras. No caso de Ribeirão Branco, o mesmo ocorre com as cidades de Itapeva, Guapiara, Nova Campina, Apiaí, Iporanga, Buri, Capão Bonito entre outras. Em ambas as situações, com as cidades do entorno seria possível coletar RSU de uma população de aproximadamente 200 mil habitantes. Consórcios dos pequenos municípios seria uma opção para o uso das tecnologias mencionadas de gaseificação.

O investimento sempre deve ser considerado como dimensão estratégica e considerando a sinergia com os benefícios ambientais do saneamento básico, e não apenas sob o ponto de vista econômico, uma vez que os investimentos são sempre de grande porte. Dados numéricos de investimentos foram discutidos no capítulo sexto.

\subsection{RESÍDUOS AGROPASTORIS}

A partir do fato que os municípios têm vocação para o agronegócio, resíduos agropastoris assumem papel relevante. Dejetos de animais, quando dispostos de forma incorreta, trazem graves prejuízos ao meio ambiente como já discutido no capítulo sexto. As questões ambientais vão além da diminuição das emissões de carbono pois o aproveitamento desses efluentes contribui para que eles não contaminem solo e águas, prejudicando fauna, flora e populações do entorno. Porém seu aproveitamento como matéria-prima para biodigestão anaeróbica possibilita a geração de biogás para aproveitamento energético e biofertilizantes, reduzindo fortemente o potencial dano ambiental.

O biogás tem importante papel na entrada de energias renováveis na matriz energética do país. Embora ainda com pequena participação, seu potencial teórico chega a 80 milhões $\mathrm{m}^{3}$ gás/dia. Este biocombustível é forte candidato a substituir o diesel nas propriedades rurais. No Brasil é produzido a partir de dejetos da pecuária (suína, aves, bovina intensiva), rejeitos do processamento da cana-de-açúcar entre outros. O biogás adentrou no plano de expansão da energia elétrica, sinalizando crescimento de sua participação na geração de energia renovável (BNDES, 2018).

Dados da ANEEL (nov. 2019) sobre geração distribuída indicam que existem o Brasil, 199 unidades geradoras na categoria UTE (usina termo elétrica), com $51.076 \mathrm{~kW}$ de potência 
total. A tabela 7.2 apresenta dados detalhados para geração de biogás através de biomassa, onde se observa a reduzida quantidade de plantas.

Apesar do enorme potencial, os dados mostram que ainda há um longo caminho a ser percorrido para o aproveitamento energético de resíduos rurais. Embora existam programas específicos para financiamento nessa categoria, como o Programa ABC do BNDES, que financia projetos para redução de impactos ambientais causados por atividades agropastoris (tratamento de dejetos está incluso), disponível para pessoa física, jurídica e cooperativas, com carência de até 8 anos, juros entre 5,25 a $7 \%$ ao ano com valores até R \$5 milhões (BNDES, 2019), entre outros.

O mercado de opções de crédito para geração de energia renovável é dinâmico, podendo surgir novas opções de financiamento por meio de organismos nacionais e internacionais a qualquer tempo.

Assim, há necessidade de maiores incentivos para investimentos desse tipo, com fontes renováveis de energia a partir de biomassa residual. Estes incentivos podem ser na forma de subsídios, linhas de crédito mais facilitadas, melhores condições para a venda de energia gerada (não só o crédito) entre outros.

Tabela 7.2: Geração distribuída - UTE por fonte (nov. 2019)

\begin{tabular}{|l|c|c|}
\hline \multicolumn{1}{|c|}{$\begin{array}{c}\text { Fonte utilizada para geração de } \\
\text { biogás }\end{array}$} & Número de unidades & Potência instalada (kW) \\
\hline Resíduo animal & 123 & 17.059 \\
\hline Resíduo sólido urbano & 28 & 8.236 \\
\hline Resíduo agroindustrial & 18 & 2.682 \\
\hline TOTAL & 169 & 27.977 \\
\hline
\end{tabular}

Fonte: ANEEL. Unidades Consumidoras com Geração Distribuída (2019) 


\subsection{BARREIRAS ECONÔMICAS}

Existem barreiras que já foram mencionadas acima. Entre elas, a questão econômica é a de maior importância, haja visto que o investimento pode ser bastante vultoso a depender da tecnologia e volumes a serem processados. Importante ressaltar que cada projeto precisa de um estudo econômico detalhado, com todas as variáveis locais para que se avalie a viabilidade econômica, mas para ilustrar este estudo traz alguns números relativos a valores de investimento, manutenção e operação.

Especificamente para as cidades estudadas, a melhor situação seria fazer aproveitamento de dejetos de animais, efluentes das casas de farinha e lodo do tratamento de esgotos através da biodigestão anaeróbica. O RSU juntamente com outros resíduos agrícolas e de beneficiamento da mandioca e castanha, seriam aproveitados através da gaseificação. A implantação do projeto de gaseificação está orçada em aproximadamente $\mathrm{R} \$ 83$ milhões de custo com $\mathrm{R} \$ 5$ milhões para manutenção. Já os projetos de biodigestão precisam ser calculados caso a caso devido a inúmeras variáveis envolvidas (volume de dejetos, uso do biogás, condições gerais da propriedade, entre outros).

Para haver incremento no aproveitamento energético dos dejetos e efluentes das propriedades rurais, é preciso haver mais divulgação técnico-econômica, com ações que podem começar em cooperativas para sensibilizar os produtores rurais sobre os benefícios ambientais e econômicos, bem como maior incentivo com implantação de políticas de financiamento ou algum subsídio para favorecer os que optam por esta solução.

\subsection{OUTRAS BARREIRAS}

As questões de mais fácil visualização, que atuam como barreiras no aproveitamento energético da biomassa residual, são as que envolvem a parte financeira (custos, financiamento, subsídios). É imprescindível que a viabilidade econômica considere também custos envolvidos com a questão social e ambiental.

A necessidade de políticas claras por parte do Estado é fundamental e deve ser vista como prioridade pois envolvem a área sanitária, energética e do bem-estar social, inclusive com simplificação dos processos regulatórios que envolvem vários setores (energia, meio ambiente, saúde entre outros).

Especificamente abordando os dois municípios deste estudo, a baixa escolaridade é considerada barreira, uma vez que os projetos citados necessitam de mão-de-obra qualificada. 
Um atenuante para tal é que, embora sem cursos técnicos nos municípios Ribeirão Branco e Itapicuru, existem centros tecnológicos e universidades em regiões próximas, de modo a formar ou fornecer a mão-de-obra necessária.

A falta de conhecimento não atinge só a população, mas também a autoridades nas três esferas. O aproveitamento energético é conhecido superficialmente muitas vezes, fazendo com que a real possibilidade dessa implementação seja ainda distante em várias situações, principalmente nos municípios de baixo desenvolvimento. Essa situação também é discutida por Coelho et al (2019) como barreira para países da América Latina. Ressalta-se ainda que, para tomada de financiamentos, quando disponíveis, há necessidade de pessoal capacitado para apreciação de editais e elaboração de projetos.

A questão cultural deve ser considerada também. Qualquer mudança de comportamento exige um trabalho de conscientização da população envolvida. Existe uma barreira natural para qualquer mudança proposta, isso faz parte da natureza do ser humano, e no caso da implantação de usinas de aproveitamento energético da biomassa, as populações do entorno tendem a não

aprovar a solução por temerem odores, ruídos e problemas à saúde (COELHO et al, 2019). É preciso um esforço conjunto entre autoridades, comunidade científica, e demais responsáveis pela destinação correta dos resíduos para a criação de um programa de sensibilização dos atores, inclusive com treinamento para as autoridades locais e formadores de opinião.

Outra resistência que pode surgir vem das empresas concessionárias de limpeza urbana. Há uma tendência de se pensar em perda no negócio, inclusive cogitando questões legais uma vez que essas concessionárias trabalham sob contratos estabelecidos para exploração do serviço de limpeza urbana. Mais uma vez a informação correta é fundamental, pois ao envolver as empresas como parte da solução (e do negócio) essa resistência vai se dissipando uma vez que podem surgir outros negócios para a sustentabilidade econômica dessas empresas (COELHO et al, 2019).

\subsection{ESTRATÉGIAS SUGERIDAS}

Para fechamento deste capítulo, faz-se aqui uma compilação de possíveis estratégias para o estímulo ao aproveitamento energético da biomassa residual, apresentadas a seguir:

- Ampla divulgação e incentivo à Pesquisa e Desenvolvimento envolvendo energias renováveis a partir de resíduos; 
- Criação de um "selo verde" para os envolvidos nos projetos de aproveitamento energético. Para os produtores de alimentos, esse diferencial pode estar inserido em políticas públicas para aquisição de itens para merenda escolar, abastecimento de estabelecimentos de saúde, entre outros;

- Estratégias informativas diversas, com sensibilização, informação e capacitação de populações envolvidas, empresários, autoridades e formadores de opinião;

- Modernização de marco regulatório e obrigações de mercado voltadas para o incremento do uso de energia gerada por biomassa residual, com envolvimento das concessionárias de energia e de limpeza pública;

- Linhas de crédito robustas e ampla divulgação, principalmente para o pequeno produtor rural;

- Estratégias de promoção de sistemas de gestão energético-ambiental para prefeituras, relacionando desenvolvimento sustentável e adequação à PNRS e Plano Nacional de Saneamento Básico;

- Estímulo ao estudo de viabilidade para criação de condomínios agro energéticos;

- Criação de comitês (com empresários - inclusive do setor energético, comunidade científica, fornecedores de equipamentos e outros atores) para proposta de soluções, pois as autoridades da maioria dos municípios têm dificuldade em visualizar as opções e fazer a melhor escolha;

-Diálogo com maturidade e seriedade entre empresários, classe política e demais autoridades envolvidas, visando atingir objetivos do desenvolvimento sustentável.

O início de qualquer ação para aproveitamento energético de resíduos pode começar pelas opções que oferecem o menor número de barreiras. Considerando custos, tecnologia e equipamentos disponíveis no país bem como o sucesso de projetos implantados, a digestão anaeróbica é a primeira escolha para aproveitamento energético de resíduos nos casos em que a biomassa em questão assim o permitir conforme as questões técnicas envolvidas.

\subsection{CONCLUSÕES DO CAPÍTULO}

Verificando as condições atuais (setor elétrico, economia, saneamento básico entre outras), foi possível elencar barreiras ao aproveitamento energético da biomassa residual. Prevalecem questões político - econômicas entre outras citadas. 
Algumas sugestões pautadas no incentivo, informação e divulgação de ordem técnicoeconômica foram mencionadas para subsidiar o desenvolvimento sustentável a partir da utilização de biomassa residual como fonte de energia. 


\section{CONCLUSÃO}

Esta tese teve como objetivo avaliar o aproveitamento energético da biomassa residual para elevação da qualidade de vida em municípios com baixo IDHM.

O trabalho foi inspirado no Projeto BREA - Biomass Residues as Energy Source to Improve Energy Access and Local Economic Activity in Low HDI Regions of Brazil and Colombia (GNESD, 2015) e buscou avaliar o potencial, limitações e impactos do aproveitamento energético da biomassa residual na qualidade de vida da população, mensurada através do IDHM, nas cidades estudadas (Ribeirão Branco - SP e Itapicuru - BA).

A partir do levantamento dos dados socioeconômicos dos municípios estudados, verificou-se que são característicos do país, com maior parte da população vivendo em áreas rurais, tendo eles vocação para o agronegócio e muitas dificuldades nas três dimensões avaliadas pelo IDH: saúde, educação e renda. Esses municípios apresentam população com maior vulnerabilidade pela instabilidade econômica, infraestrutura insuficiente, descaso do poder público, políticas equivocadas entre outras questões. Além de tudo isso, a desigualdade entre cidadãos brasileiros fica evidente, pois mesmo a pior situação no Estado de São Paulo é superior às condições de vida do município baiano em estudo.

O levantamento quantificado da disponibilidade de resíduos urbanos, industriais e agropastoris, bem como sua caracterização, indicou a possibilidade do aproveitamento energético através da digestão anaeróbica para esgotos e dejetos de animais nos dois casos, e de águas residuais das casas de farinha e beneficiamento da castanha em Itapicuru.

Os resíduos da silvicultura, agrícolas e do beneficiamento de castanha e mandioca (em Itapicuru), bem como o RSU de ambos os municípios, podem ter seu aproveitamento através da gaseificação. Neste caso, além de não necessitar de aterros para a disposição desses resíduos, há a possibilidade de ser feita a mineração em valas e lixões já existentes, de forma a auxiliar a adequação dos municípios à PNRS. Muito do potencial energético das cidades, principalmente de Itapicuru, é “exportado" pois a produção de laranja, coco-da-baía e outras frutas, além de aves, é encaminhada para indústrias situadas em outras regiões.

A geração da energia a partir da biomassa residual produzida em ambos municípios, através da gaseificação para resíduos sólidos, em paralelo à digestão anaeróbica para dejetos de animais, esgoto e manipueira, de forma combinada, podem representar significativo acréscimo 
na energia disponível para os municípios, tendo como grande benefício a questão ambiental pela sinergia com o saneamento básico.

O acesso à energia é indispensável para possibilitar educação, saúde e renda, as três dimensões consideradas para determinação do IDHM, aos cidadãos. Assim, o aproveitamento energético da biomassa residual pode fomentar o desenvolvimento sustentável. Além da segurança energética, questões ambientais e socioeconômicas podem ser mais bem equacionadas com a adoção dessas soluções de aproveitamento energético da biomassa residual.

Aspectos ambientais envolvidos referem-se ao controle da poluição do ar, contaminação do solo, de águas subterrâneas e superficiais, além do impacto na biodiversidade. Esgoto e efluentes diversos lançados a esmo, bem como resíduos sólidos (agropastoris ou domésticos) dispostos inadequadamente geram poluição visual, contaminação do solo por matéria orgânica ou substâncias tóxicas, geram emissões de GEE e, percolando no solo, atingem lençóis freáticos e corpos d’água.

Aspectos sociais estão diretamente ligados à saúde pública. Há estreita ligação entre saneamento básico e desenvolvimento humano, visto através de números no Brasil e no mundo. A disposição equivocada de resíduos sólidos ou líquidos acarreta agravos à saúde, promovendo o aparecimento de pragas, vetores e outro agentes causadores de doenças do trato gastrointestinal entre outras. O risco é extensivo a cidadãos que "vivem" do lixo como catadores e funcionários da limpeza urbana. Investimentos nesta área configuram-se como economia aos cofres públicos na área da saúde.

A relação entre aproveitamento energético de resíduos estudada até aqui relaciona-se com aspectos econômicos a partir do fato que bem-estar físico, mental e social gerados pelos aspectos abordados neste capítulo impactam na produtividade no trabalho e na escola. $\mathrm{O}$ turismo é beneficiado, ampliando vagas de trabalho e circulação de dinheiro nos municípios (ambos os estudados têm oportunidades nessa área). Percebe-se ganhos diretos e indiretos com a instalação de projetos nas cidades, com geração de emprego e renda. Há de se citar a geração de impostos que fortalece o caixa do município e favorece, em contrapartida, a população.

Somente através da cooperação será possível atingir-se as 169 metas envolvidas nos 17 ODS. A sinergia entre saneamento básico e aproveitamento energético de biomassa residual é indispensável para tal. Considerando que os municípios estudados têm vocação para o agronegócio, assim como muitos outros municípios do país, a interrelação entre saneamento e 
geração de energia a partir de resíduos sustenta parte do conceito de agroecologia, onde a produção de alimentos respeita o meio ambiente e todo ecossistema envolvido.

Com maior disponibilidade de energia, gerada pelos resíduos, há contribuição nas necessidades domésticas, não só as básicas como iluminação, aquecimento, refrigeração e cocção, mas na comunicação, lazer e maior conforto com a utilização de novos equipamentos eletroeletrônicos.

Considerando os benefícios na educação, eletricidade propicia climatização nas regiões mais quentes, melhorando o conforto térmico e aumentando o rendimento escolar. Há também o uso do computador e outras tecnologias para uso pedagógico. Na saúde, a eletricidade pode proporcionar além de infraestrutura mais adequada para os atendimentos (instalações e equipamentos), melhor condição para estocagem de medicamentos e vacinas, além do tratamento de água e esgoto.

Refletindo sobre o uso produtivo a partir da energia gerada através da biomassa residual, nas propriedades rurais há possibilidade da aplicação da energia no aquecimento e resfriamento das granjas, bombeamento e uso na irrigação, fabricação de artesanato e em pequenas fábricas de alimentos regionais. Com isso, há criação de empregos e geração de renda em toda cadeia produtiva, favorecendo direta e indiretamente a circulação de ativo monetário nas cidades, inclusive com a geração de impostos.

Verificando o contexto atual dos municípios estudados, percebe-se que existem barreiras para a implantação dos projetos para geração de energia, na questão econômica (custos e condições de financiamento), falta de capacitação de pessoal, falta de informação inclusive das autoridades locais, questões políticas e legais.

Medidas de incentivo, informação e divulgação são necessárias. Importante citar a necessidade da modernização do marco regulatório, incentivos (econômico e fiscais) específicos para uso de resíduos na geração de energia, estímulo para o produtor rural através de estudo de viabilidade econômica e abordagem integrada na proposta de políticas públicas voltadas às questões energéticas, ambientais e ao saneamento básico.

Esse estudo apresenta algumas limitações, como dados governamentais nem sempre atualizados, dificuldade ou impossibilidade de acesso a locais de disposição de resíduos por questões de mobilidade ou segurança para observação e registro de imagens, desconfiança dos 
munícipes para emitir comentários e percepções. Mais estudos com essa temática, envolvendo qualidade de vida gerada pelo aproveitamento energético de resíduos são desejados.

Estudos sobre o tema, com foco na bioeconomia - modelo de produção para oferecer soluções sustentáveis com alternativas de recursos renováveis, podem ampliar a visão a respeito dos impactos do uso energético de biomassa residual sobre os indicadores de desenvolvimento humano.

Por tudo que foi exposto, pode-se inferir que os indicadores de renda, educação e saúde tomarão movimento ascendente, alavancados pelo aproveitamento energético da biomassa residual, acarretando a elevação do IDHM dos municípios.

A tese teve com foco Itapicuru - BA e Ribeirão Branco - SP, ambos com baixo desenvolvimento perante seus respectivos estados, segundo critérios do IDHM, mas os resultados podem ser pensados para mais de 1.500 municípios com baixo desenvolvimento no país, que possuem potencial de resíduos. Caso as quantidades sejam insuficientes para uso das tecnologias atuais, é possível estimular parcerias para o ganho de escala. 


\section{REFERÊNCIAS}

ABES. Associação Brasileira de Engenharia Sanitária e Ambiental. Seção Minas Gerais. Unidade de recuperação Energética de Barueri. Disponível em: <http://www.abesmg.org.br/visualizacao-de-clipping/ler/5808/ure-barueri-unidade-de-recuperacao-energeticade-residuos-solidos 26/1/2015>. Acesso em 26 nov. 2019.

ABNT. Associação Brasileira de Normas Técnicas. ABNT NBR 10004:2004 Resíduos sólidos - Classificação. São Paulo: ABNT, 2004.

ABRELPE - Associação Brasileira de Empresas de Limpeza Pública e Resíduos Especiais. Panorama dos Resíduos Sólidos no Brasil 2011. São Paulo: ABRELPE, 2012. Disponível em: 〈http://abrelpe.org.br/download-panorama-2011〉. Acesso em: 10 dez. 2019.

Panorama dos Resíduos Sólidos no Brasil 2017. 72p. São Paulo: ABRELPE, 2018. ISSN 2179-8303.

Panorama 2018/2019. São Paulo: ABRELPE, 2019. Disponível em:

<http://abrelpe.org.br/download-panorama-2018-2019/>. Acesso em: $10 \mathrm{dez} .2019$.

ACTUALITIX. World Atlas - Statistics by Country. Taxa de mortalidade infantil (por 1000 nados vivos) 2016. Disponível em: <https://pt.actualitix.com/pais/wld/taxa-de-mortalidadeinfantil.php>. Acesso em: 09 out. 2019.

ADIL, A. M.; KO, Y. "Socio-technical evolution of decentralized energy systems: a critical review and implications for urban planning and policy". Renewable and Sustainable Energy Reviews, v. 57, pp. 1025-1037, 2016.

ANEEL. Agência Nacional de Energia Elétrica. Geração distribuída. 2018. Disponível em: <https://www.aneel.gov.br/geracao-distribuida>. Acesso em: 28 nov. 2019.

. Geração distribuída. Dados atualizados 2019. Disponível em:

<https://www.aneel.gov.br>. Acesso em: 28 nov. 2019.

Tarifas. Disponível em: <https://www.aneel.gov.br>. Acesso em: 28 nov. 2019.

BAHIA. SEI - Superintendência de Estudos Econômicos e Sociais da Bahia. Sistemas de Informações Municipais. Disponível em:

<http://sim.sei.ba.gov.br/sim/informacoes_municipais.wsp>. Acesso em: 23 jun. 2019.

BARRERA, P. Biodigestores: energia, fertilidade e saneamento para a zona rural. 2. Ed. São Paulo: Ícone, 1993.

BARROS, Francisco Fábio Cavalcante et al. Surfactina: propriedades químicas, tecnológicas e funcionais para aplicações em alimentos. Química Nova, v. 30, n. 2, p. 409-414, 2007.

BARROS, R.P. et al. Desigualdade e Pobreza no Brasil: retrato de uma estabilidade inaceitável. Revista Brasileira de Ciências Sociais, v.15, n. 42, pp.123-142, 2000. Disponível em: <http://www.scielo.br/pdf/rbcsoc/v15n42/1741〉. Acesso em 02 jan. 2018. 
BIASI, C. A. F. et al. Energias Renováveis na Região Sul do Brasil. Foz do Iguaçu: Itaipu Binacional. 2018. 202p.

BNB. Banco do Nordeste. Manual de aspectos ambientais: orientações básicas sobre aspectos ambientais de atividades produtivas. 297p. Fortaleza: Banco do Nordeste, 1999. Disponível em: <https://www.mma.gov.br>. Acesso em: 02 nov. 2019.

BNDES. Banco Nacional de Desenvolvimento Econômico e Social. Biogás de resíduos agroindustriais: panorama e perspectivas. BNDES Setorial, v. 47, p. 221-276, mar. 2018. Rio de Janeiro. ISSN 1414-9230.

Programa ABC. 2019. Disponível em:

<https://www.bndes.gov.br/wps/portal/site/home/financiamento/produto/programa-abc>. Acesso em: 30 nov. 2019.

BOSE, M. L. V.; MARTINS FILHO, J. G. O papel dos resíduos agroindustriais na alimentação de ruminantes. Informe Agropecuário, Belo Horizonte, v. 10, n. 119, p. 3-7, nov. 1984.

BRASIL. Constituição da República Federativa do Brasil: texto constitucional promulgado em 5 de outubro de 1988, com as alterações determinadas pelas Emendas Constitucionais de Revisão nos 1 a 6/94, pelas Emendas Constitucionais nos 1/92 a 91/2016 e pelo Decreto Legislativo no 186/2008. Brasília: Senado Federal, Coordenação de Edições Técnicas, 2016. 496 p. Disponível em:

<https://www2.senado.leg.br/bdsf/bitstream/handle/id/518231/CF88_Livro_EC91_2016.pdf>. Acesso em: 12 dez. 2019.

BRASIL. Câmara dos Deputados. Projeto de Lei n. 2.289, de 2015. Prorroga o prazo para a disposição final ambientalmente adequada dos rejeitos de que trata o art. 54 da Lei $\mathrm{n}^{\circ}$ 12.305, de 2 de agosto de 2010. Disponível em:

$<$ https://www.camara.leg.br/proposicoesWeb/prop_mostrarintegra?codteor=1417642\&filena $\mathrm{me}=\mathrm{SBT}+2+\mathrm{CMADS}+\% 3 \mathrm{D} \% 3 \mathrm{E}+\mathrm{PL}+2289 / 2015>$. Acesso em: 18 out. 2019.

Notícias. Câmara aprova novo marco do saneamento. Disponível em:

<https://www.camara.leg.br/noticias/625574-plenario-aprova-texto-base-do-novo-marco-dosaneamento/>. Acesso em: 13 dez. 2019.

BRASIL. MME. Ministério das Minas e Energia. Programa Luz Para Todos - O programa. Disponível em: < http://luzparatodos.mme.gov.br/luzparatodos/asp/>. Acesso em 15 set. 2017.

Luz Para Todos vai beneficiar mais de 380 mil pessoas em 2019. 2018.

Disponível em: <http://www.mme.gov.br/web/guest/pagina-inicial/outras-noticas//asset_publisher/32hLrOzMKwWb/content/mais-380-mil-pessoas-serao-beneficiadas-com-oprograma-luz-para-todos-em-2019>. Acesso em: 30 out. 2019.

Assessoria de comunicação. Principais destaques do dia. WEG entra no setor de geração a partir de resíduos. 2019. Disponível em: 
<http://www.mme.gov.br/documents/78404/105400/Clipping+13-09-

2019.docx.pdf/57ddbe73-3056-94f0-f5e9-cf659ae79088>. Acesso em: 12 dez. 2019.

BRASIL. MS. Ministério da Saúde. Blog da Saúde. Promoção da Saúde. Saúde investe em ações para aumentar a longevidade do brasileiro. dez. 2012. Disponível em: < http://www.blog.saude.gov.br/index.php/promocao-da-saude/31654-saude-investe-em-acoespara-aumentar-longevidade-do-brasileiro>. Acesso em: 23 jun. 2019.

BRASIL. Presidência da República. Casa Civil. Lei 9394 de 20/12/1996. Estabelece diretrizes e bases da educação nacional. DOU, Brasília, DF, 23 dez. 1996. Disponível em: <http://www.planalto.gov.br/ccivil_03/leis/19394.htm>. Acesso em: 15 set. 2019.

Lei n. 12.305, de 2 de agosto de 2010. Institui a Política Nacional de Resíduos Sólidos; altera a Lei no 9.605, de 12 de fevereiro de 1998 e dá outras providências. Diário Oficial da União, Brasília, 03 ago. 2010.

BURKE III, E. The Big Story - Human History, Energy Regimes, and the Environment. In: Burke III, E. The Environment and World History, pp. 33-53. California: University Press, 2009.

CALZA, L. F. et al. Avaliação dos custos de implantação de biodigestores e da energia produzida pelo biogás. Eng. Agríc. Jaboticabal, v. 35, n. 6, p. 990-997, dez. 2015. Disponível em: <http://www.scielo.br/scielo.php?script=sci_arttext\&pid=S010069162015000600990\&lng=en\&nrm=iso >. Acesso em: 25 nov. 2019.

CAMPELLO, T. et al. Faces da desigualdade no Brasil: um olhar sobre os que ficam para trás. Saúde Debate, Rio de Janeiro, v. 42, n. especial 3, p. 54-66, nov. 2018. Disponível em: <http://www.scielo.br/pdf/sdeb/v42nspe3/0103-1104-sdeb-42-spe03-0054.pdf>. Acesso em: 01 set. 2019.

CARBOGAS. Informações obtidas com departamento técnico da empresa pela autora. 2019.

CARMO, M. E.; GUIZARDI, F. L. O conceito de vulnerabilidade e seus sentidos para as políticas públicas de saúde e assistência social. Cadernos de Saúde Pública, Rio de Janeiro, v. 34, n. 3, mar. 2018. ISSN:1678-4464. Disponível em:

$<$ http://cadernos.ensp.fiocruz.br/csp/artigo/393/o-conceito-de-vulnerabilidade-e-seussentidos-para-as-polticas-pblicas-de-sade-e-assistncia-social>. Acesso em: 23 jun. 2019.

CETESB. Companhia Ambiental do Estado de São Paulo. Inventário Estadual de resíduos sólidos urbanos 2018. São Paulo: CETESB, 2019. 120p.

CHESF - Companhia Hidrelétrica do São Francisco. Disponível em: <https://www.chesf.gov.br/Pages/default.aspx>. Acesso em: 24 jun. 2019.

CHIRI, G. M.; GIOVAGNORIO, I. The role of the city's shape in urban sustainability. International Transaction Journal of Engineering, Management \& Applied Sciences \& Technologies, v.3, pp. 245-258, 2012. 
CNDSS. Comissão Nacional Sobre Determinantes Sociais Da Saúde. As Causas Sociais das Iniquidades em Saúde no Brasil - Relatório Final. 2008. Disponível em: <http://www.cndss. fiocruz.br/pdf/home/relatorio.pdf.>. Acesso em 01 nov. 2019.

COELBA. Companhia de Eletricidade do Estado da Bahia. Disponível em:

<http://servicos.coelba.com.br/>. Acesso em: 24 jun. 2019.

COELHO, S.T. Biomassa como Fonte de Energia: Conversão e Utilização. 2015. São Paulo. Notas de aula. Instituto de Energia e Ambiente. USP.

COELHO, S.T. (Coord). Tecnologias de produção e uso de biogás e biometano. São Paulo: IEE-USP, 2018. 218 p. ISBN: 978-85-86923-53-1.

COELHO, S. T. et al. Atlas de Bioenergia do Brasil. São Paulo: Cenbio, 2009. 57 p.

Biomass Residues as Electricity Generation Source for Residential and Productive Uses: An Analysis of Poverty Alleviation, Energy Access, and Carbon Footprint in Low Human Development Index Regions of Brazil. In: The XI Latin-American Congress on Electricity Generation and Transmission - CLAGTEE. São José dos Campos, 2015.

COELHO, S. T. et al. Existing Barriers for WtE in Developing Countries and Policy Recommendations. In: Municipal Solid Waste Energy Conversion in Developing Countries Technologies, Best Practices, Challenges and Policy. Elsevier, 290p. 2019 eBook ISBN: 9780128134207.

COELHO, S. T.; GARCILASSO, V. P. Usos de Biomassa, Biodigestores e Biogás. 2019. São Paulo. Notas de aula PECE-EPUSP Programa de educação continuada.

COELHO, S. T.; GOLDEMBERG, J. Energy access: Lessons learned in Brazil and perspectives for replication in other developing countries. Energy Policy. New York, v. 61, pp. 1088-1096, oct. 2013.

Interesse energético e mudanças climáticas. In. GRANZIERA, M.L.M; REI, F. (Org) O futuro do regime internacional das mudanças climáticas. Aspectos jurídicos e institucionais. Santos: Editalivros Produções Editoriais, 2015. 276 p.

CORTEZ, C.L. Estudo do potencial de utilização da biomassa da poda de árvores urbanas para geração de energia: estudo de caso AES Eletropaulo. 2011. 246 f. Tese de Doutorado. Programa de Pós-Graduação em Energia, Universidade de São Paulo, São Paulo, 2011.

CORTEZ, L.A.B.; LORA, E.E.S.; GÓMEZ, E.O. (org) Biomassa para Energia. Campinas: Editora Unicamp, 2008.

CORTEZ, L.A.B.; LORA, E.E.S.; GÓMEZ, E.O. Biodigestão de Efluentes. In: Biomassa para Energia. Campinas: Editora Unicamp, 2008.

COSTA, M. A. O direito de acesso à energia: meio e pré-condição para o exercício do direito ao desenvolvimento e dos direitos humanos. 2009. 222 p. Tese de Doutorado. 
Instituto de Energia e Ambiente, Programa de Pós-Graduação em Energia. Universidade de São Paulo. São Paulo, 2009.

CRADDOCK, P. From hearth to furnace: evidences for the earliest metal smelting technologies in the Eastern Mediterranean. In: Paléorient. vol. 26, n. 2. pp. 151-165. 2000.

CROSBY, A. Children of the Sun. Chapter I: Fire and cooking, pp. 7-24, New York: W.W. Norton \& Company, 2006.

DANTAS, M.D. Povoamento e Ocupação do Sertão de Dentro Baiano (Itapicuru, 1549 1822). Penélope - Revista de História e Ciências Sociais. La Rioja, n.23, p.9-30, 2000. ISSN:0871-7486. Disponível em: <https://dialnet.unirioja.es/servlet/articulo?codigo=2655378>. Acesso em: 03 mai. 2019.

DIAMOND, J. Evolution, consequences and future of plant and animal domestication. Nature, London, v. 418, n. 6898, pp. 700-707, 2002.

ECONODATA. Lista de empresas. Disponível em: <https://www.econodata.com.br/listaempresas>. Acesso em: 23 jul. 2019.

EL BOUSHY, A. R.; VAN DER POEL, A. F. B. Poultry feed from waste: Processing and use. London: Chapman \& Hall, 1994.

ELEKTRO - Distribuidora de Energia. Disponível em: 〈https://www.elektro.com.br/>. Acesso em: 24 jun. 2019.

ELETROBRAS. Programa Luz Para Todos. Disponível em:

<https://eletrobras.com/pt/Paginas/Luz-para-Todos.aspx>. Acesso em: 28 nov. 2019.

EMBASA - Empresa Baiana de Águas e Saneamento. Relação de Municípios Atendidos com Abastecimento de Água e Esgotamento Sanitário em 2018. Disponível em:

<http://www.embasa.ba.gov.br/images/Institucional/aembasa/areadeatuacao/20190327_INFO _RelMunicipiosAtendidos.pdf>. Acesso em: 23 jun. 2019.

EMBRAPA - Empresa Brasileira de Pesquisa Agropecuária, Centro de Pesquisa Agropecuária de Clima Temperado. A cultura da maçã. Coleção Plantar. Brasília: EMBRAPA-SPI, 1994. 107 p. ISBN 85-85007-25-7.

Centro Nacional de Pesquisa de Mandioca e Fruticultura Tropical. A cultura do maracujá, Coleção Plantar. Brasília: EMBRAPA-SPI, 1994. 76 p. ISBN: 85-85007-17-6. Disponível em: <https://ainfo.cnptia.embrapa.br/digital/bitstream/item/162334/1/A-culturado-maracuja.pdf $>$. Acesso em 15 ago. 2019.

Aproveitamento Industrial do Caju. Documentos No 38, jun. 2000. ISSN 0103-

5797. Disponível em:

<https://www.agencia.cnptia.embrapa.br/Repositorio/Aproveitamento_industrialCaju_000g0a v435602wx5ok026zxpgjh8ac94.pdf>. Acesso em 20 ago. 2019.

Plantando caju. Projeto Lumiar. Fortaleza: Embrapa Agroindústria Tropical, 2000.

33p. Disponível em: 
<https://www.agencia.cnptia.embrapa.br/Repositorio/Plantando_caju_000g0591zi302wx5ok0 q43a0rzjrqez3.pdf>. Acesso em 25 jul. 2019.

Cultura do coqueiro: sistemas de manejo. Aracaju: Embrapa Tabuleiros Costeiros, 2001. 23p. ISSN 1517-1329. Disponível em:

$<$ https://ainfo.cnptia.embrapa.br/digital/bitstream/item/64525/1/cpatc-documentos-32-culturado-coqueiro-sistemas-de-manejo-fl-06838.pdf>. Acesso em: 25 jul. 2019.

- A cultura da cebola. Coleção Plantar n. 45. Brasília: Embrapa Informação Tecnológica, 2002. 107 p. ISBN 85-7383-158-8. Disponível em:

<https://www.infoteca.cnptia.embrapa.br/handle/doc/108708>. Acesso em: 10 ago. 2019.

\section{Comparativo de Custos de Implantação de Diferentes Tecnologias de}

Armazenagem/ Tratamento e Distribuição de Dejetos Suínos. Circular Técnica 42.

Concórdia, junho 2005. Disponível em:

<http://www.cnpsa.embrapa.br/sgc/sgc_publicacoes/publicacao_c6f75b0x.pdf $>$. Acesso em: 25 nov. 2019.

Boas Práticas de Produção de Frangos de Corte. Circular Técnica. Embrapa suínos e aves. Concórdia, 2007. Disponível em: <https://ainfo.cnptia.embrapa.br/digital/bitstream/CNPSA/16385/1/publicacao_s8t285e.pdf>. Acesso em: 14 out. 2019.

. Ovinos: o produtor pergunta, a Embrapa responde. Coleção 500 perguntas, 500 respostas. Brasília, DF: Embrapa Informação Tecnológica, 2007. 158 p. ISBN 978-85-7383389-8. Disponível em:

<https://ainfo.cnptia.embrapa.br/digital/bitstream/item/101775/1/500perguntasovinos.pdf > . Acesso em 15 ago. 2019.

A cultura do melão. 2 Ed. rev. ampl. Coleção Plantar. Brasília: Embrapa Informação Tecnológica, 2008. 191 p. Disponível em: $<$ https://ainfo.cnptia.embrapa.br/digital/bitstream/item/11920/2/00068380.pdf >. Acesso em: 23 jul. 2019.

Sistema de Produção de Melancia. Sistemas de Produção, v. 05. Petrolina: Embrapa Semiárido, 2009. ISSN 1807-0027. Disponível em: <https://sistemasdeproducao.cnptia.embrapa.br/FontesHTML/Melancia/SistemaProducaoMel ancia/index.htm>. Acesso em: 23 jul. 2019.

Sistemas de Produção - Cultivo de Pinnus. 2. Ed. 2014. ISSN 1678-8281.

Disponível em:

<https://www.spo.cnptia.embrapa.br/conteudo?p_p_id=conteudoportlet_WAR_sistemasdepro ducaolf6_1galceportlet\&p_p_lifecycle=0\&p_p_state=normal\&p_p_mode=view\&p_p_col_id =column-2\&p_p_col_count=1\&p_r_p_-76293187_sistemaProducaoId=3715\&p_r_p_996514994_topicoId=3228>. Acesso em: 25 jul. 2019.

Maracujá: o produtor pergunta, a Embrapa responde. Coleção 500 perguntas, 500 respostas. Brasília: Embrapa, 2016. 341 p. ISBN 978-85-7035-617-8. Disponível em: <https://www.embrapa.br/busca-de-publicacoes/-/publicacao/1061917/maracuja-o-produtorpergunta-a-embrapa-responde>. Acesso em: 24 jul. 2019. 
Ageitec - Agência Embrapa de Informação Tecnológica. Agroecologia. 2019.

Disponível em:

<https://www.agencia.cnptia.embrapa.br/gestor/agricultura_e_meio_ambiente/arvore/CONTA G01_8_299200692526.html>. Acesso em: 16 out. 2019.

EPE. Empresa de Pesquisa Energética. Inventário de Resíduos Sólidos Urbanos. Serie Recursos energéticos. Nota técnica DEA 18/14. Rio de Janeiro: EPE, 2014. Disponível em: <www.epe.gov.br>. Acesso em: 01 dez. 2019.

Plano Decenal de Expansão de Energia 2027. Brasília: Ministério de Minas e Energia. Empresa de Pesquisa Energética, 2018. Disponível em: $<$ http://www.mme.gov.br/documents/10584/1432059/Plano+Decenal+de+Expans\%C3\%A3o +de+Energia+2027+\%28PDE+2027\%29/66498aa7-5e33-47ea-b586-

2a6b1b994f7f?version=1.1>. Acesso em: $12 \mathrm{dez} .2019$.

Sistemas Isolados. 2019. Disponível em: <http://www.epe.gov.br/pt/publicacoesdados-abertos/publicacoes/sistemas-isolados>. Acesso em: 20 nov. 2019.

FAO - Organização das Nações Unidas para a Alimentação e a Agricultura. El estado de la seguridad alimentaria y la nutrición en el mundo. Fomentando la resiliencia climática en aras de la seguridad alimentaria y la nutrición. 199 p. Roma: FAO, 2018. Disponível em: <http://www.fao.org/3/I9553ES/i9553es.pdf>. Acesso em: 02 set. 2019.

FEIDEN, A.; CEREDA, M. P. Potencial energético do biogás gerado no tratamento de águas residuárias de fecularias em sistema piloto de biodigestão anaeróbia com separação de fases. Energia na Agricultura, Botucatu, v. 18, n. 2, pp. 54-66, 2003.

FGV. Fundação Getúlio Vargas. Instituto Brasileiro de Economia. Balanço e disponibilidade interna de gêneros alimentícios de origem vegetal: 1986 a 1990. Rio de Janeiro, 1991. 70p.

FIORETTO, A. M. et al. Manejo, uso e tratamento de subprodutos da industrialização da mandioca. Série cultura de tuberosas amiláceas latino-americanas, v. 4. São Paulo: Fundação Cargil, 2001. 320 p.

FLECK, M.P.A. et al. Desenvolvimento da versão em português do instrumento de avaliação de qualidade de vida da OMS (WHOQOL-100). Rev. Bras. Psiquiatr., São Paulo, v.

21, n.1, p. 19-28, mar. 1999. Disponível em:

$<$ http://www.scielo.br/scielo.php?script=sci_arttext\&pid=S1516-

44461999000100006\&lng=en\&nrm=iso>. Acesso em: 01 nov. 2019.

G1. PIB do Brasil cresce 1,1\% em 2018 e ainda está no patamar de 2012. Disponível em: <https://g1.globo.com/economia/noticia/2019/02/28/pib-do-brasil-cresce-11-em-2018.ghtml>. Acesso em: 15 nov. 2019.

GADELHA, A. M. T. et al. Análise Comparativa da Casca da Castanha de Caju com e sem LCC para Produção Sustentável de Combustível Sólido. In: Congresso Técnico Científico da Engenharia e da Agronomia CONTECC, 2015, Fortaleza. Trabalhos Premiados. Brasília: CONFEA, 2015. Disponível em: 
<http://www.confea.org.br/sites/default/files/antigos/Trabalhos_Premiados_2015_analise_co mparativa_da_casca_da_castanha_de_caju_com_e_sem_1.pdf $>$. Acesso em: 27 jul. 2019.

GAMA, M.L.S. Planejamento e Gestão do Tratamento de dejetos de suínos no Distrito Federal: aplicação de instrumentos de avaliação multicriterial. 2003. 101 p. Dissertação. Programa de Pós-Graduação em Planejamento e Gestão Ambiental Universidade Católica de Brasília. Brasília, 2003.

GARCILASSO, V.P.; FERRAZ JUNIOR, A.D.N. Biogás. In: COELHO, S.T. (Coord.) Tecnologias de Produção de Biogás e Biometano. Ebook. São Paulo: IEE - USP, 2018. Disponível em: <http://gbio.webhostusp.sti.usp.br/sites/default/files/anexosnoticias/livrotecnologias-producao-uso-biogas-biometano.pdf >. Acesso em: 05 out. 2019. 218p.

GIODA, A. et al. Exposição ao uso da lenha para cocção no Brasil e sua relação com os agravos à saúde da população. Ciênc. saúde coletiva, Rio de Janeiro, v. 24, n. 8, p. 30793088, ago. 2019. Disponível em:

<http://www.scielo.br/scielo.php?script=sci_arttext\&pid=S1413-

81232019000803079\&lng=en\&nrm=iso>. Acesso em: 29 out. 2019.

GNESD - Global Network on Energy for Sustainable Development. Biomass Residues as Energy Source to Improve Energy Access and Local Economic Activity in Low HDI Regions of Brazil and Colombia (BREA). Revised Final Report. Copenhagen: GNESD, set. 2015, 368 p.

GODFRAY, H.C.J. et al. Food Security: The Challenge of Feeding 9 Billion People. Science, Washington D.C., v. 327, n. 5967, pp. 812-818, 2010.

GOLDEMBERG, J. Energia e Desenvolvimento. Estudos Avançados, São Paulo, v. 12, n. 33,1998. Disponível em: <http://www.scielo.br/pdf/ea/v12n33/v12n33a02.pdf>. Acesso em: 23 dez. 2017.

O Mundo e o Homem: uma agenda do século XXI à luz da ciência. São Paulo: Perspectiva, 2008. 242p.

GOLDEMBERG, J. et al. Expanding Access Eletricity in Brazil. Energy for Sustainable Development, Amsterdam, v. VIII, n. 4, p. 86-94, dec. 2004. Disponível em: $<\mathrm{http} / / / \mathrm{www}$.iee.usp.br/gbio/sites/default/files/2004\%20Expanding\%20access\%20to\%20elect ricity\%20in\%20Brazil.pdf>. Acesso em: 03 jan. 2018.

GOLDEMBERG, J.; COELHO, S. T. Viewpoint Renewable energy-traditional biomass vs. modern biomass. Energy Policy. Amsterdam, v. 32, pp. 711-714, 2004. Disponível em: <http://143.107.4.241/download/publicacoes/EP_tradbiomass.pdf >. Acesso em: 02 jan. 2018.

GOLDEMBERG, J.; LUCON, O. Energia, Meio Ambiente \& Desenvolvimento. 3.Ed. São Paulo: EDUSP, 2012. 400 p.

GONCALVES, K. S.; CASTRO, H. A.; HACON, S. S. As queimadas na região amazônica e o adoecimento respiratório. Ciênc. Saúde Coletiva, Rio de Janeiro, v. 17, n. 6, p. 15231532, jun. 2012. Disponível em: 
<http://www.scielo.br/scielo.php?script=sci_arttext\&pid=S1413-

81232012000600016\&lng=en\&nrm=iso > . Acesso em: 02 nov. 2019.

GOOGLE MAPS. Mapas. Disponível em: < https://www.google.com.br/maps>. Acesso em 23 dez. 2017.

GOUVEIA, N. Resíduos sólidos urbanos: impactos socioambientais e perspectiva de manejo sustentável com inclusão social. Ciência \& Saúde Coletiva. Rio de Janeiro, v.17, n.6, p. 1503 - 1510, 2012. Disponível em: <http://www.scielo.br/scielo.php?pid=S1413$81232012000600014 \&$ script=sci_abstract\&tlng=pt>. Acesso em: 20 set. 2017.

GRUPTA, A.K. Origin of agriculture and domestication of plants and animals linked to early Holocene climate amelioration. Current Science, Bengaluru, v. 87, n. 1, pp. 54-59, 2004. Disponível em: <http://www.ias.ac.in/currsci/jul 102004/54.pdf>. Acesso em: 12 jul. 2017.

HARISH, V.S.K.V.; KUMAR, A. A review on modeling and simulation of building energy systems. Renewable and Sustainable Energy Reviews, Amsterdam, v. 56, pp. 1272-1292, 2016.

HELENE, M. E. M.; CERQUINHO, M. Energy for Sustainable World - resenha. Revista Brasileira de Energia, Rio de Janeiro, v. 1, n. 1, 1989. Disponível em: <http://new.sbpe.org.br/wp-content/themes/sbpe/img/artigos_pdf/v01n01/v01n01rs3.pdf>. Acesso em: 03 jan. 2018.

IBGE - Instituto Brasileiro de Geografia e Estatística. PNAD Continua. Rendimento de todas as fontes 2017. Rio de Janeiro: IBGE, 2018. Disponível em: <https://biblioteca.ibge.gov.br/visualizacao/livros/liv101559_informativo.pdf>. Acesso em: 05 out. 2019.

PNAD Continua. Educação 2018. Rio de Janeiro: IBGE, 2019. Disponível em: $<$ https://agenciadenoticias.ibge.gov.br/media/com_mediaibge/arquivos/00e02a8bb67cdedc4fb 22601ed264c00.pdf>. Acesso em 07 out. 2019. jan. 2019.

Cidades Brasileiras. Disponível em: <https://cidades.ibge.gov.br/>. Acesso em: 23

Agência de Notícias. PNAD Contínua: taxa de desocupação é de 12,0\% e taxa de subutilização é $24,8 \%$ no trimestre encerrado em junho de 2019. Disponível em: $<$ https://agenciadenoticias.ibge.gov.br/agencia-sala-de-imprensa/2013-agencia-denoticias/releases/25092-pnad-continua-taxa-de-desocupacao-e-de-12-0-e-taxa-desubutilizacao-e-24-8-no-trimestre-encerrado-em-junho-de-2019>. Acesso em: 06 out. 2019.

Expectativa de vida sobe para 76,3 em 2018. Disponível em: $<$ https://agenciadenoticias.ibge.gov.br/agencia-noticias/2012-agencia-denoticias/noticias/26103-expectativa-de-vida-dos-brasileiros-aumenta-para-76-3-anos-em2018>. Acesso em: 06 out. 2019.

Estimativas da população residente no Brasil e unidades da federação com data de referência em 1 jul. 2019. Dipsonível em: 
<https://agenciadenoticias.ibge.gov.br/media/com_mediaibge/arquivos/7d410669a4ae85faf4e 8c3a0a0c649c7.pdf>. Acesso em: 12 dez. 2019.

IEA. International Energy Agency. Energy Access Outlook. From poverty to prosperity. 2017. Disponível em: < https://www.iea.org/reports/energy-access-outlook-2017>. Acesso em: 02 jul. 2019.

World Energy Balances - Overview. 2019. Disponível em:

<https://webstore.iea.org/download/direct/2710?fileName=World_Energy_Balances_2019_O verview.pdf>. Acesso em: 09 jul. 2019.

IIASA - International Institute for Applied Systems Analysis. GEA - Global Energy Assessment. 2012. Disponível em: 〈http://www.iiasa.org>. Acesso em: 05 mai. 2017.

ILO - International Labor Organization. World Employment Social Outlook. Trends 2019. Executive Summary. Geneve: ILO, 2019. Disponível em:

$<$ https://www.ilo.org/wcmsp5/groups/public/---dgreports/---dcomm/--publ/documents/publication/wcms_670554.pdf>. Acesso em: 07 out. 2019.

IMF. International Monetary Fund. Word Economic Outlook. 2018. Disponível em: <www.imf.org>. Acesso em: 02 ago. 2019.

INEP - Instituto Nacional de Estudos e Pesquisas Educacionais Anísio Teixeira. IDEB Índice de Desenvolvimento da Educação Básica. Disponível em:

<http://portal.inep.gov.br>. Acesso em: 06 out. 2019.

IDEB. Resultados e Metas. Disponível em: <http://ideb.inep.gov.br/resultado/> . Acesso em: 03 mai. 2019.

INFIESTA, L. Gaseificação de Residuos Solidos Urbanos (RSU) no Vale do Paranapanema - Projeto CIVAP. 2015. 137 p. Monografia (Especialização em Energias Renováveis, Geração Distribuida e Eficiência Energética), Escola Politécnica da Universidade de São Paulo PECE - Programa de Educação Continuada em Engenharia. São Paulo, 2015.

INSTITUTO PAULO MONTENEGRO. INAF - Indicador de Analfabetismo Funcional 2018 Resultados Preliminares. Disponível em: <https://drive.google.com/file/d/1ez6jrlrRRUm9JJ3MkwxEUffltjCTEI6/view>. Acesso em: 06 out. 2019.

IPEA. Instituto de Pesquisa Econômica Aplicada. Diagnóstico dos Resíduos Orgânicos do Setor Agrossilvopastoril e Agroindustrias Associadas. Relatório de Pesquisa. Brasília, 2012.

JIE. Jornal de Itaipu Eletrônico. Projeto Ajuricaba é "case" de sucesso em encontro da Unesco, evento paralelo da Rio+20. Foz do Iguaçu. 2012. Disponível em: <https://jie.itaipu.gov.br/node/50724>. Acesso em: 02 nov. 2019.

KIM, S.; DALE, B.E. (2004) Global Potential Bioethanol Production from Wasted Crops and Crop Residues. Biomass \& Bioenergy, v. 26, p. 361-375. Disponível em:

<http://dx.doi.org/10.1016/j.biombioe.2003.08.002>. Acesso em: 10 set. 2019. 
KOHAN, W. O. Paulo Freire e o valor da igualdade em educação. Educ. Pesqui., São Paulo, v. 45, e201600, 2019. Disponível em:

<http://www.scielo.br/scielo.php?script=sci_arttext\&pid=S1517-

97022019000100529\&lng=en\&nrm=iso>. Acesso em: 08 abr. 2019

KUNZ, A.; OLIVEIRA, P.A.V. Aproveitamento de dejetos de animais para geração de biogás. Revista de Política Agrícola. Brasília, ano XV, n. 3, jul./ago./set. 2006. Disponível em: <https://ainfo.cnptia.embrapa.br/digital/bitstream/item/63324/1/Paginas-de-pol-agr-0320064-p.-28-35.pdf>. Acesso em: 15 ago. 2019.

LAMAISON, F.C. Aplicação da água residuária do processamento da mandioca como substrato para a produção de hidrogênio por processo fermentativo. $2009.83 \mathrm{p}$. Dissertação de Mestrado em Engenharia de Alimentos. Universidade Federal de Santa Catarina. Florianopolis, 2009.

LOPES, P. R. C. et al. Cultivo do Caquizeiro no Vale do São Francisco. Circular técnica on line Embrapa, dez. 2014. ISSN 1808-9976. Disponível em:

<http://www.cpatsa.embrapa.br:8080/public_eletronica/downloads/CTE107.pdf>. Acesso em: 15 ago. 2019.

LORA, E. E. S. et al. Gaseificação. In: CORTEZ, L.A.B. et al (Org.). Biomassa para Energia. 732p. Campinas, SP: Editora UNICAMP, 2008.

MANSO, K. R. J. Confinamento de bovinos: estudo do gerenciamento dos resíduos. Trabalho de conclusão de curso (Graduação em Engenharia Ambiental) - 60 Curso de Engenharia Ambiental da Pontifícia Universidade Católica de Goiás, Goiânia, 2007.

MARROCOS S. T. P. et al. Crescimento e acúmulo de nutrientes em cebola IPA 11. Horticultura Brasileira, Brasília, vol. 27, n. 02, suplemento, pp. 627-631, 2009. Disponível em: <http://www.abhorticultura.com.br/eventosx/trabalhos/ev_3/A1888_T3558_Comp.pdf>. Acesso em: 26 jul. 2019.

MAVROPOULOS, A. Saúde desperdiçada o caso dos lixões.43 p. São Paulo: Abrelpe, 2015. Disponível em: <www.abrelpe.org.br〉. Acesso em: 28 out. 2019.

MEU MUNICIPIO. Portal Meu Município. Perfil do município. Disponível em: <https://meumunicipio.org.br/>. Acesso em: 10 nov. 2019.

MINAYO, M.C.S. (Org.). Pesquisa social: teoria, método e criatividade. 18 ed. Rio de Janeiro: Vozes, 2001.

MOHOD, A.; JAIN, S. POWAR, A. Cashew Nutshell Waste: Availability in Small-Scale Cashew Processing Industries and Its Fuel Properties for Gasification. Renewable Energy, 2011, doi:10.5402/2011/346191

MOTTA, F.S. Produza sua energia: biodigestores anaeróbios. Recife: Editora S.A, 1986. $144 \mathrm{p}$.

MOURA, J I L; LEITE, J B V. Coco. Jornal CEPLAC Notícias. Brasília, mar. 2001. Disponível em: <http://www.ceplac.gov.br/radar/coco.htm>. Acesso em: 20 ago. 2019. 
NISHIOKA, D. C. et al. Estudo dos efeitos da poluição atmosférica na mortalidade neonatal e fetal na cidade de São Paulo, Brasil. Rev Med, São Paulo, abr./dez. 2000;79(2/4):81-9. Disponível em: <http://www.revistas.usp.br>. Acesso em: 13 out. 2019.

OIM. Observatório de Informações Municipais. O custo da administração municipal e a capacidade de investimentos. 2019. Disponível em:

<http://www.oim.tmunicipal.org.br/abre_documento.cfm?arquivo=_repositorio/_oim/_docum entos/6D645D19-FEB9-42DD-F5E96F453F64937E29072019113018.pdf\&i>. Acesso em: 10 nov. 2019.

OLIVEIRA, L.F. et al. Aproveitamento alternativo da casca do maracujá-amarelo (Passiflora edulis F. Flavicarpa) para produção de doce em calda. Ciência e Tecnologia de Alimentos, Campinas, v. 22, p. 259-262, 2002.

OLIVEIRA, P. M. C. P. Universalização do acesso à energia elétrica como vector do desenvolvimento económico. 2013. 60 p. Dissertação de Mestrado. Faculdade de Economia, Universidade do Porto, Porto, 2013.

ONS. Operador Nacional do Sistema Elétrico. Disponível em: <http://www.ons.org.br/>. Acesso em: 10 dez. 2019.

ONU. Organização das Nações Unidas. Declaração do Milênio. Nova Iorque: ONU, 2000. Disponível em: <http://www.pnud.org.br/Docs/declaracao_do_milenio.pdf >. Acesso em: 11 set. 2016

Fatos sobre Energia Sustentável - Rio + 20 O Futuro que queremos. Rio de Janeiro: ONU, 2012. Disponível em: < http://www.onu.org.br/rio20/energia.pdf>. Acesso em: 12 set. 2016.

Transformando Nosso Mundo: A Agenda 2030 para o Desenvolvimento Sustentável. Nova Iorque: ONU, 2015. Disponível em: <http://www.pnud.org.br/Docs/TransformandoNossoMundo.pdf>. Acesso em: 11 set. 2016.

. OMS define 10 prioridades de saúde para 2019. ONU Brasil, Brasília, 16 jan. 2019. Disponível em: <https://nacoesunidas.org/oms-define-10-prioridades-de-saude-para-2019/>. Acesso em: 10 out. 2019.

- Acabar com a pobreza é possível, mas significa confrontar a desigualdade. ONU Brasil, Brasília, 18 fev. 2019. Disponível em: <https://nacoesunidas.org/artigo-acabar-com-apobreza-e-possivel-mas-significa-confrontar-a-desigualdade-dentro-e-entre-os-paises $>$ Acesso em: 05 set. 2019.

World economic situation and prospects 2019. 218 p. New York: UN, 2019.

Disponível em: <https://www.un.org/development/desa/dpad/wpontent/uploads/sites/45/WESP2019_BOOK-web.pdf>. Acesso em: 05 set. 2019.

A ONU e o meio ambiente. 2019. Disponível em:

<https://nacoesunidas.org/acao/meio-ambiente/>. Acesso em: 03 jan. 2019. 
OPAS - Organização Pan Americana de Saúde. Indicadores de Saúde. Disponível em: $<$ https://www.paho.org/hq/index.php?option=com_content\&view=article\&id=14401:healthindicators-conceptual-and-operational-considerations-section- $1 \&$ Itemid $=0 \&$ lang $=\mathrm{pt}>$. Acesso em: 10 out. 2019.

PAVAN, M. C. O. Geração de Energia a Partir de Resíduos Sólidos Urbanos: Avaliação e Diretrizes para Tecnologias Potencialmente Aplicáveis no Brasil. 2010. 186 p. Tese de Doutorado. Instituto de Energia e Ambiente, Programa de Pós-Graduação em Energia, Universidade de São Paulo, São Paulo, 2010.

PENSAMENTO VERDE. Nosso Futuro em comum: conheça o relatório de Brundtland. Disponível em: <http://www.pensamentoverde.com.br/sustentabilidade/nosso-futuro-emcomum-conheca-o-relatorio-de-brundtland/>. Acesso em: 04 jan.2018.

PEREIRA, K. A. et al. Utilização de Resíduo Industrial de Tomate (RIT) na Alimentação de Ruminantes: revisão de literatura. Nutritime, Viçosa, vol. 14, n. 02, mar. / abr. de 2017. ISSN: 1983-9006. Disponível em:

<https://www.nutritime.com.br/arquivos_internos/artigos/Artigo_415.pdf>. Acesso em 22 ago. 2019.

\section{PLATAFORMA DE BOAS PRÁTICAS PARA O DESENVOLVIMENTO} SUSTENTÁVEL. Condomínio Ajuricaba de Agroenergia para Agricultura Familiar. Disponível em: <http://www.boaspraticas.org.br/index.php/pt/areas-tematicas/energiasrenovaveis/16-condominio-ajuricaba-de-agroenergia-para-agricultura-familiar $>$. Acesso em: 02 nov. 2019.

PNUD. Programa das Nações Unidas para o Desenvolvimento. Relatório do Desenvolvimento Humano Brasil 2009/2010 - Valores e Desenvolvimento Humano. Brasília: PNUD, 2010. Disponível em:

<http://www.pnud.org.br/hdr/arquivos/rdh_brasil_2009_2010.pdf>. Acesso em: 10 set. 2017.

Relatório do Desenvolvimento Humano de 2014 - Sustentar o Progresso Humano: Reduzir as Vulnerabilidades e Reforçar a Resiliência. Nova Iorque: PNUD, 2014. Disponível em: 〈http://www.pnud.org.br/arquivos/RDH2014pt.pdf〉. Acesso em: 10 set. 2017.

2017.

Sobre o PNUD. Disponível em: <http://www.br.undp.org/>. Acesso em: 22 dez.

Atlas do Desenvolvimento Humano no Brasil. Acesso em:

<http://atlasbrasil.org.br>. Acesso em: 22 dez. 2019.

Desenvolvimento Humano e IDH. 2019. Disponível em:

<https://www.br.undp.org/content/brazil/pt/home/idh0.html>. Acesso em: 01 nov. 2019.

PNUD, IPEA, FJP. Índice de Desenvolvimento Humano Municipal Brasileiro. Brasília: 2013. 96 p. Atlas do Desenvolvimento Humano no Brasil 2013. ISBN: 978-85-7811-171-7. Disponível em:

<http://repositorio.ipea.gov.br/bitstream/11058/2375/1/Livro_O\%20\%C3\%8Dndice\%20de\%2 0Desenvolvimento\%20Humano\%20Municipal\%20Brasileiro.pdf $>$. Acesso em: 29 out. 2019. 
POHLMANN, M. Levantamento de técnicas de manejo de resíduos da bovinocultura leiteira no estado de São Paulo. 115p. 2000. Dissertação (Mestrado de Engenharia Agrícola) - Universidade Estadual de Campinas. Faculdade de Engenharia Agrícola, Campinas. 2000.

PRADO JR, C. História econômica do Brasil. São Paulo: Ed Brasiliense, 2017. 365 p.

REN21. Reneable Energy Policy Network for the 21st Century. Global Status Report. Paris, 2017. Disponível em: <http://www.ren21.net/wp-content/uploads/2017/06/178399_GSR_2017_Full_Report_0621_Opt.pdf>. Acesso em: 02 jan. 2018.

RESCH, G. et al. Potentials and prospects for renewable energies at global scale. Energy Policy, v. 36; n. 11, p. 4048-4056, out. 2008. doi:10.1016/j.enpol.2008.06.029

RIBEIRO, N. et al. Manual de Silvicultura Tropical. Maputo: Universidade Eduardo Mondlane, 2002. Disponível em:

<https://www.agencia.cnptia.embrapa.br/Repositorio/silvicultura2_000g7dvzi9202wx5ok0wt edt3bo11r6z.pdf>. Acesso em jun. 2019.

ROCHA, A. D. et al. Qualidade de vida, ponto de partida ou resultado final? Ciênc. saúde coletiva, Rio de Janeiro, v. 5, n. 1, p. 63-81, 2000. Disponível em:

$<$ http://www.scielo.br/scielo.php?script=sci_arttext\&pid=S1413-

81232000000100007\&lng=en\&nrm=iso>. Acesso em: 01 nov. 2019

RUSSELL, B. CONTE, J. (trad.) Os problemas da Filosofia. Oxford University Press, 1959.

SAAE - Serviço Autônomo de Água e Esgoto. Estação de Tratamento de Esgoto, 2013.

Estação Bandeirantes (PR). Disponível em:

<http://bandeirantes.pr.gov.br/editais/Roteiro_ETE.pdf>. Acesso em: 03 mar. 2019.

SABESP. Companhia de Saneamento Básico do estado de São Paulo. Município de Ribeirão Branco. RQA. 2017. Disponível em: <www.sabesp.com.br>. Acesso em: 23 jun. 2019.

. Sabesp começa a abastecer carros em Franca com os gases do tratamento de esgoto. 2018. Disponível em: <http://site.sabesp.com.br/site/imprensa/noticiasdetalhe.aspx? secaoId=65\&id=7838>. Acesso em: 30 out. 2019.

SANCHES-PEREIRA A.; TUDESCHINI L. G.; COELHO, S. T. Evolution of the Brazilian residential carbon footprint based on direct energy consumption. Renewable and

Sustainable Energy Reviews. v. 54, p. 184-201. 2016. Disponível em:

<http://www.sciencedirect.com/science/article/pii/S1364032115009946>. Acesso em: 29 out. 2019.

SANTANA-MÉRIDAS, O. et al. Agricultural residues as a source of bioactive natural products. Phytochemistry Reviews, v.11, n. 04, pp. 447-466, 2012. DOI 10.1007/s11101012-9266-0.

SANTOS, G. J.; MARION, J. C.; SEGATTI, S. Administração de custos preços na agropecuária. 4. ed. São Paulo: Atlas, 2009. 
SANTOS, J. S. Questão social (livro eletrônico): particularidades do Brasil. 1. Ed. Coleção Biblioteca Básica de Serviço Social, v.6, 1,9 Mb. São Paulo: Cortez, 2017.

SANTOS, T. M. B. Balanço energético e adequação do uso de biodigestores em galpões de frangos de corte. 2001. 167 f. Tese de Doutorado. Fac. de Ciências Agrárias e Veterinária, Universidade Estadual Paulista, Jaboticabal, 2001.

SÃO PAULO (Estado). Secretaria da Infraestrutura e Meio Ambiente. Programa Município VerdeAzul. Disponível em:

$<$ https://www.infraestruturameioambiente.sp.gov.br/verdeazuldigital/>. Acesso em: 20 jun. 2019.

Dados Energéticos. Disponível em: <http://dadosenergeticos.energia.sp.gov.br>. Acesso em: 24 jun. 2019.

SEE4ALL (Sustainable Energy for all). Universal Energy Access. New York: ONU, 2011. Disponível em: < http://www.se4all.org/our-vision/our-objectives/universal-energy/>. Acesso em: 10 set. 2017.

SIEFERLE, R. The subterranean forest. Energy systems and the industrial revolution. Chapter II: Forrest and Wood in Preindustrial Germany. Cambridge: The White Horse Press, 2001. pp.47-77.

SMIL, V. Traditional agricultures: foundations and advances. Energy - a beginner's guide. Oxford: Oneworld Publications, 2006.

Creating modern materials civilization and Materials in the Twentieth Century. Making of the modern world: Materials \& dematerialization. UK: Wiley, 2013.

SOUSA, L.; GALANTE, H.; FIGUEIREDO, D. Qualidade de vida e bem-estar dos idosos: um estudo exploratório na população portuguesa. Revista de Saúde Pública, São Paulo, v.37, n.3, p.364-371, jun. 2003.

SOUZA, S. N. M. et al. Custo da eletricidade gerada em conjunto motor gerador utilizando biogás da suinocultura. In: 5. Encontro de Energia no meio rural, 2004, Campinas. Proceedings online... Disponível em:

$<$ http://www.proceedings.scielo.br/scielo.php?script=sci_arttext\&pid=MSC00000000220040 00100042\&lng=en\&nrm=abn>. Acesso em: 25 nov. 2019.

TELEBRASIL. Associação Brasileira de Telecomunicações. Mapa de ERBs Brasil.

Disponível em: < http://www.telebrasil.org.br/panorama-do-setor/mapa-de-erbs-antenas>. Acesso em: 15 jun. 2019.

TRATA BRASIL. Instituto Trata Brasil. Benefícios econômicos e sociais da expansão do saneamento no Brasil. São Paulo: Trata Brasil, 2018. Disponível em: $<$ http://abconsindcon.com.br/wp-content/uploads/2018/11/Relat\%C3\%B3rioBenef\%C3\%ADcios-do-saneamento-no-Brasil-v.-01-11-2018.pdf>. Acesso em: 27 out. 2019. 
. Saneamento - Principais Estatísticas. São Paulo: Trata Brasil, 2019. Disponível em: <http://www.tratabrasil.org.br/saneamento/principais-estatisticas>. Acesso em: 10 nov. 2019.

UNAL, H.; ALIBAS, K. Agricultural Residues as Biomass Energy. Energy Sources Part B - Economics Planning and Policy, Abingdon - UK, v. 02, n. 02, pp. 23-140, 2007. DOI:10.1080/15567240600629401.

UNPD. United Nations Development Program. UN Human Development Report

2007/2008. 2008. Disponível em: <www.hdr.undp.org>. Acesso em: 02 fev. 2019.

International Human Development Indicators. Disponível em:

<http://hdr.undp.org/en/countries>. Acesso em: 05 jan. 2018.

URANI, A. Crescimento e geração de emprego e renda no Brasil. Lua Nova, São Paulo, n. 35, p. 5-38, 1995. Disponível em:

<http://www.scielo.br/scielo.php?script=sci_arttext\&pid=S0102-

$64451995000100002 \& \operatorname{lng}=$ en\&nrm=iso>. Acesso em: 05 out. 2019.

VELÁZZUEZ, S.M.S. G. et al. A Geração de Energia Elétrica em Comunidades Isoladas na Amazônia a partir de Biomassa Sustentável: Projeto ENERMAD. In: Anais XIII Congresso Brasileiro de Energia - XIII CBE, nov. 2010. Rio de Janeiro. Disponível em:

<http://143.107.4.241/download/publicacoes/xiiicbe_enermad.pdf >. Acesso em: 02 nov. 2019.

VILELA, N. J. et al. Desafios e oportunidades para o agronegócio da cebola no Brasil. Hortic. Bras., Brasília, v. 23, n. 4, p. 1029-1033, dez. 2005. Disponível em: $<$ http://www.scielo.br/scielo.php?script=sci_arttext\&pid=S010205362005000400034\&lng=en\&nrm=iso>. Acesso em: 23 jul. 2019.

WALTER, A.; NOGUEIRA, L.A.H. Sistemas de Produção de Eletricidade a Partir da Biomassa. In: CORTEZ, L.A.B.; LORA, E.E.S.; GÓMEZ, E.O. (org) Biomassa para Energia. Campinas: Editora Unicamp, 2008.

WIKANDER, O. Sources of Energy and Exploitation of Power. The Oxford handbook of engineering and technology in the classical world. Oxford: Oxford University Press, 2008.

WORLDANIMALPROTECTION. Entenda o que é bem-estar animal. Disponível em: <https://www.worldanimalprotection.org.br/blogs/entenda-o-que-e-bem-estar-animal>. Acesso em: 03 dez. 2020.

WORLD BANK. Piecing Together the Poverty Puzzle. 2018. Disponível em: <https://www.worldbank.org/en/publication/poverty-and-shared-prosperity>. Acesso em: 02 set. 2019.

WORLD HEALTH ORGANIZATION \& UN-WATER. 2010. GLAAS 2010: UN-water global annual assessment of sanitation and drinking-water: targeting resources for better results. World Health Organization. Disponível em:

<https://apps.who.int/iris/handle/10665/44313>. Acesso em: 13 out. 2019. 
YIN, R. K. GRASSI, D. (Trad). Estudo de caso: planejamento e métodos. 2.ed. -Porto Alegre: Bookman, 2001. 